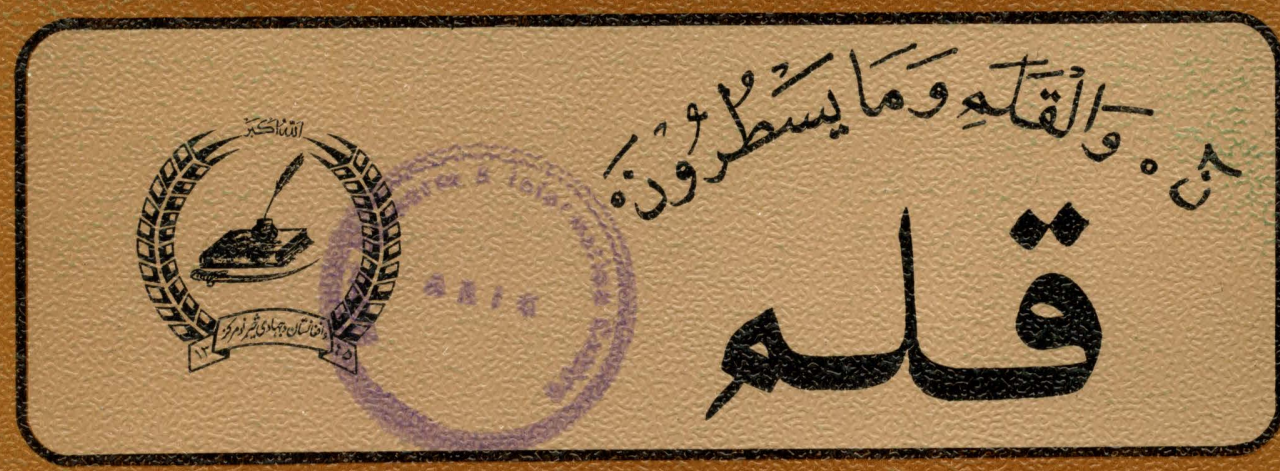

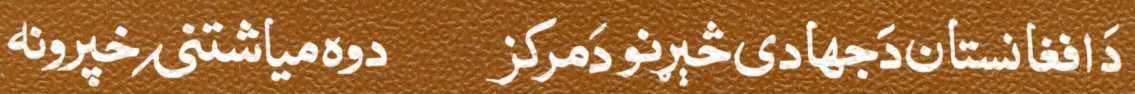

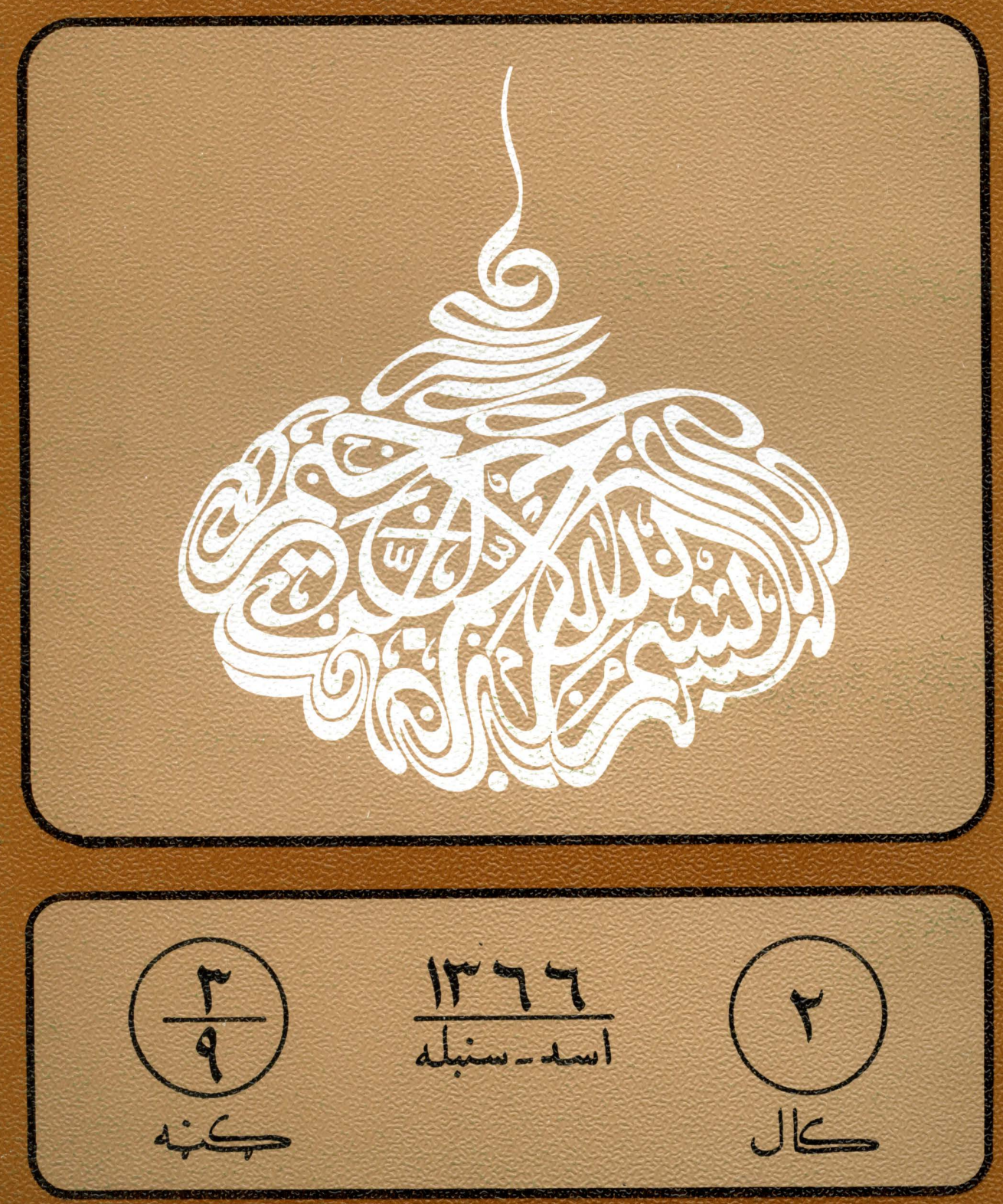




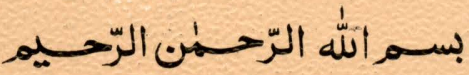

o

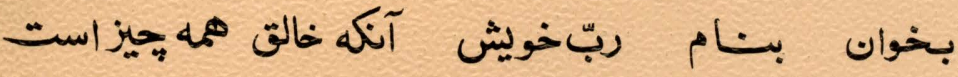

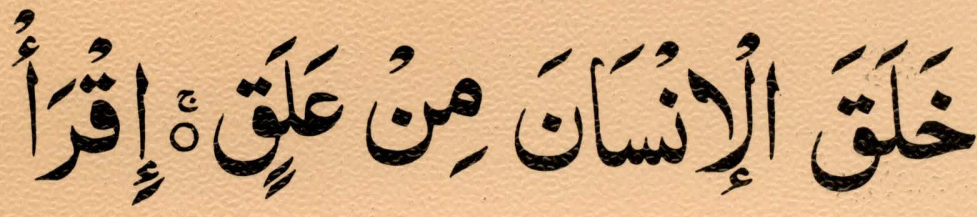

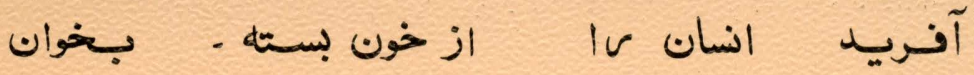

rê وب توبسـياركريم است . آنكه علم آموخت انسان رابواسطة تلم

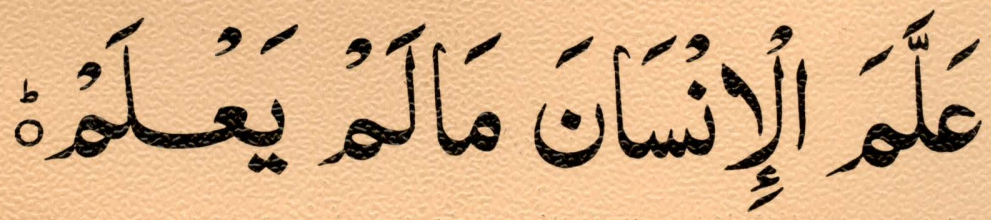

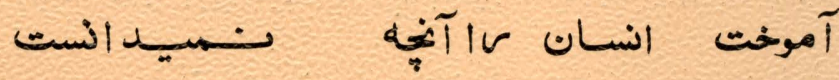
صدقالله العظبهم 

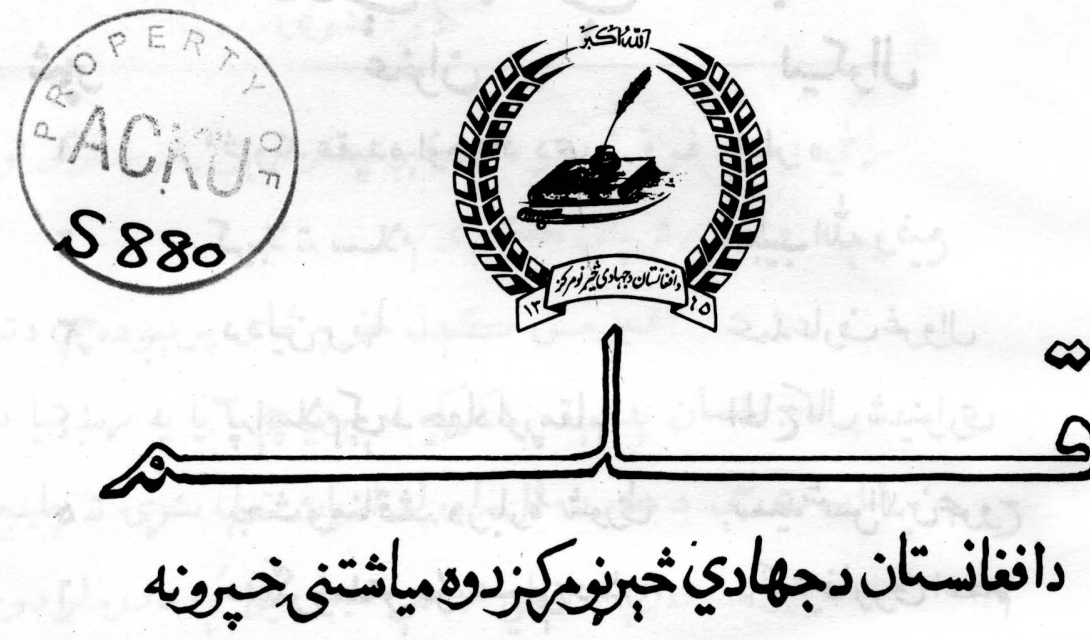

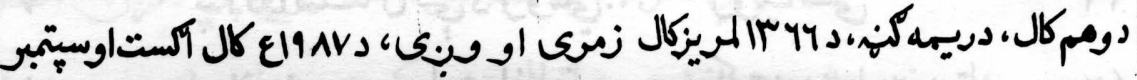

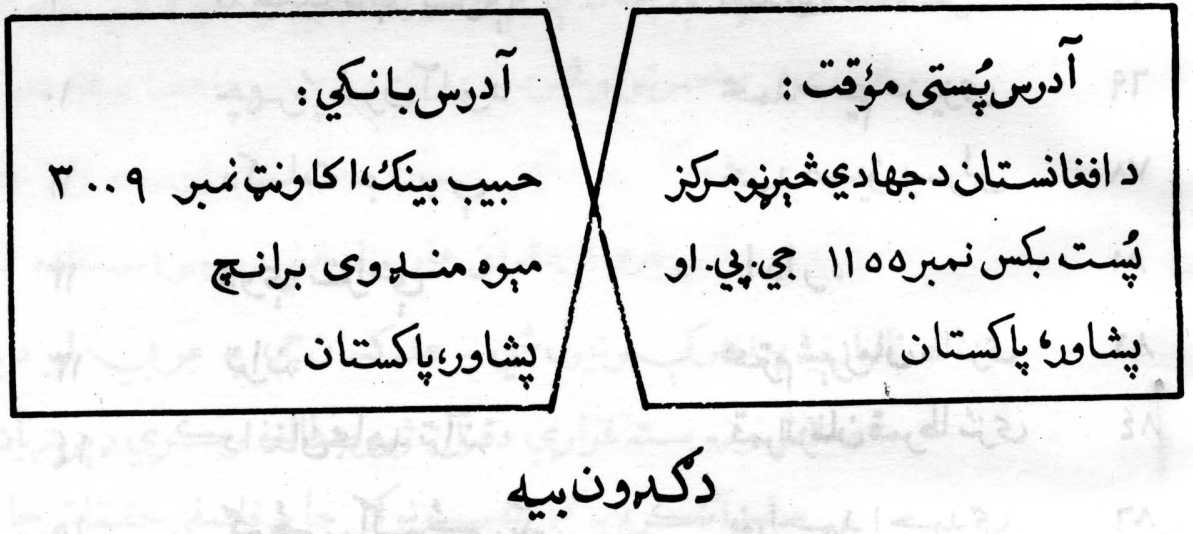

كلنىكن, ون ... اكلماري

به باكستانكي

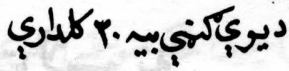

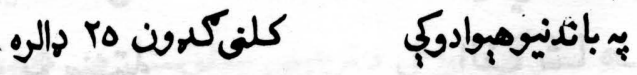

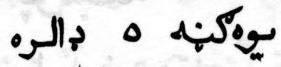


غ

1

7

معهدعارفغرال

الحاجمال شينواريى

r. سيدتمسلاينجروح

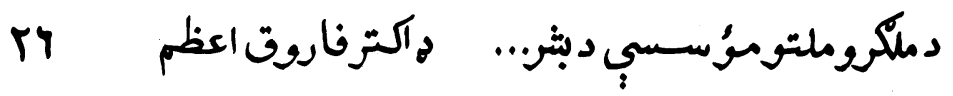

ry

$$
\text { ها نفانستانكيد روسي... روكيانس }
$$

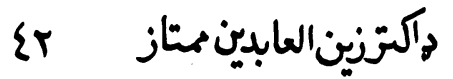

ir

اسدالهَغضنفر

79

محمدصيم عزيزى

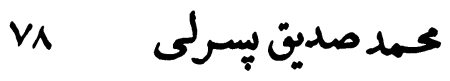

A

$$
\text { ادارد }
$$

Ar كترمشيرمان طائزى

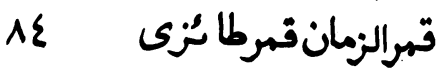

نوأحمد احمدى

امان الله نصرت 11

9. وليكمدوليانكزى

الف شاهين

ar الحاج ننكيال
اسلام نيروى جهادى انفان

$$
9
$$

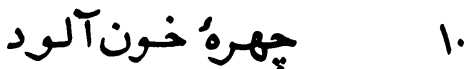

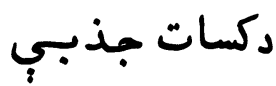

$$
\text { دوري تـرانبي }
$$

Ir

توان

Ir

دانتانباهد تئن

$1 \varepsilon$

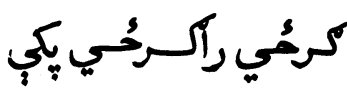

10

نمسله

14

$$
\text { IV مات لاسونه }
$$

| 11

دوه هإِشنوى تنسيرون 


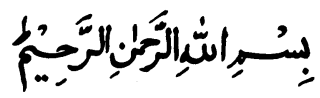

دعاثررادئي يمناسبت.

"ثوزيد عقمهاوحهاد دى!"

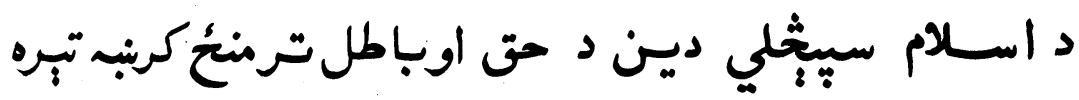

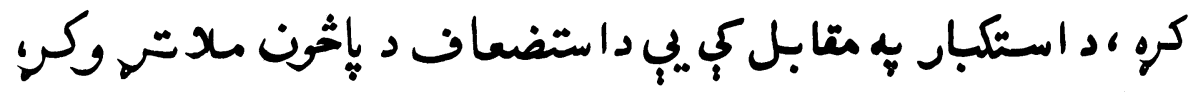

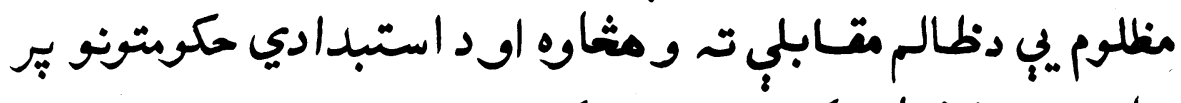

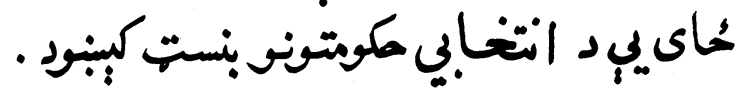

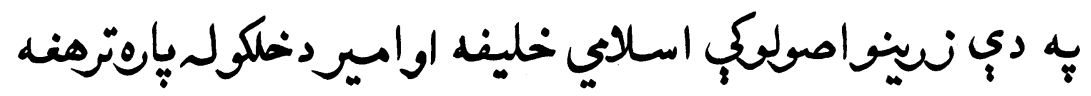

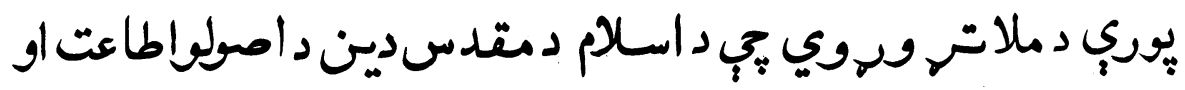

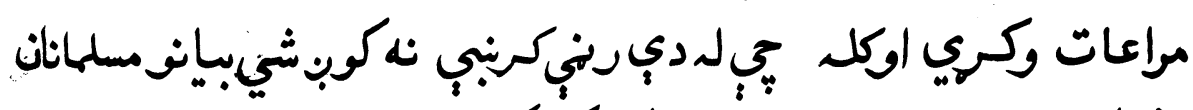

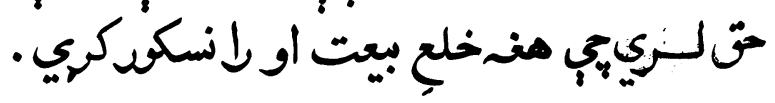

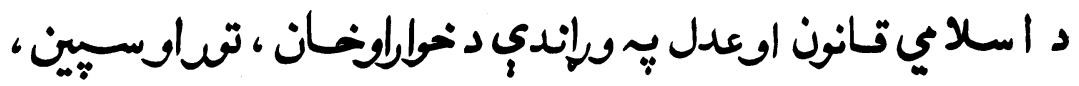

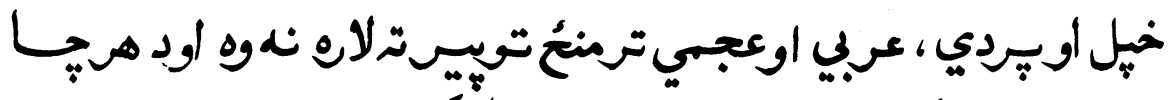

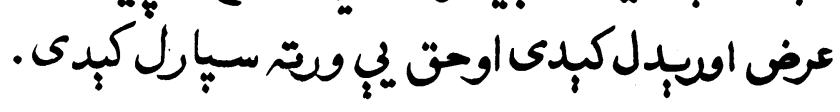

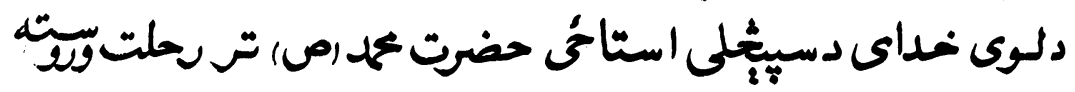




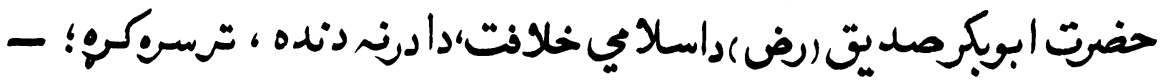

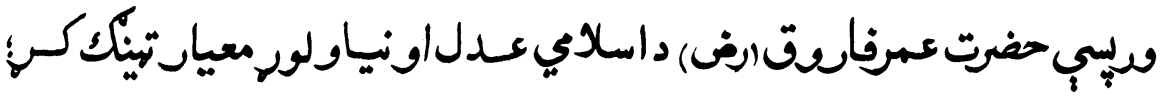

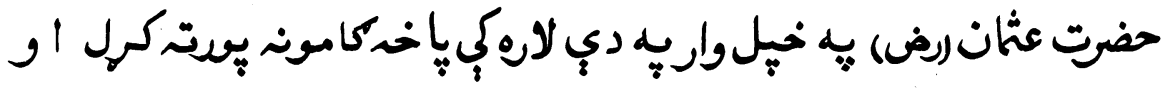

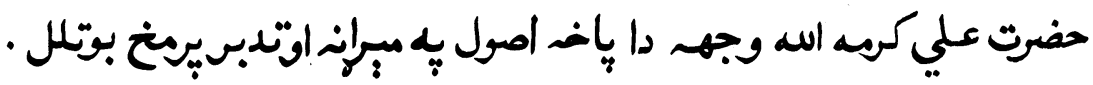

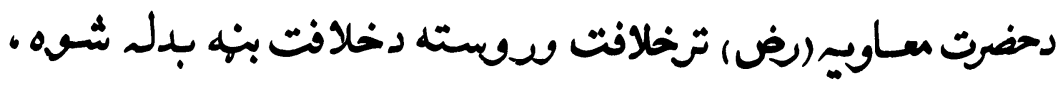

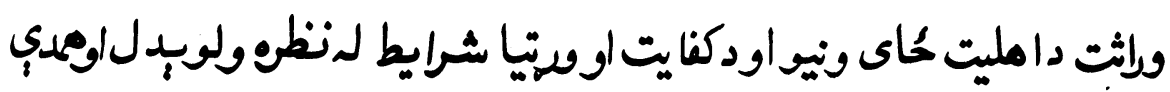

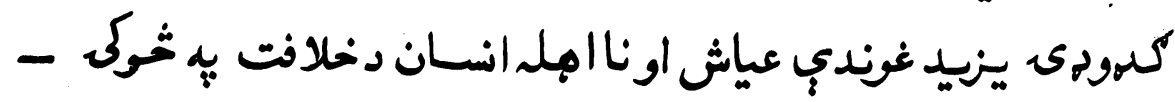

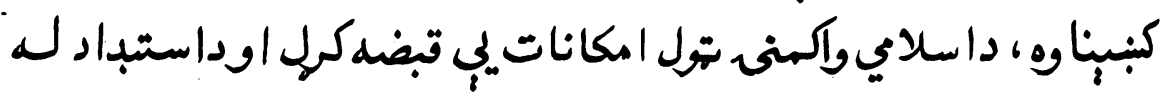

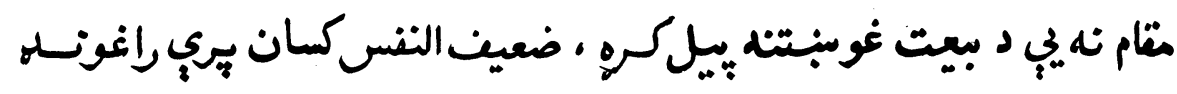

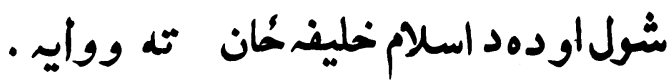

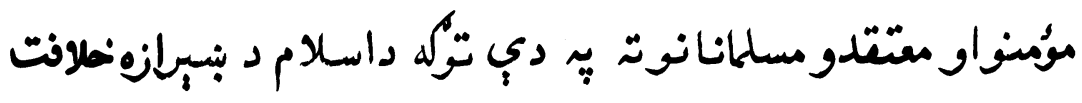

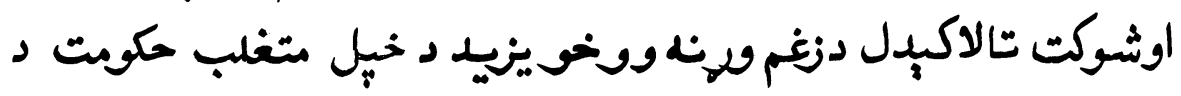

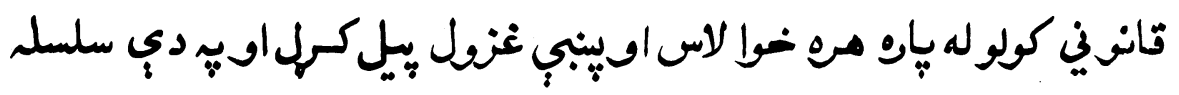

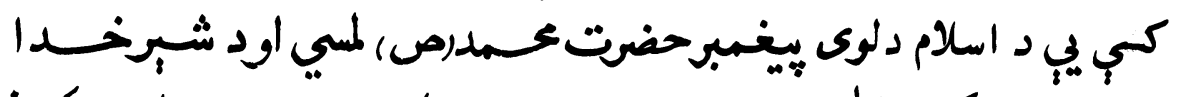

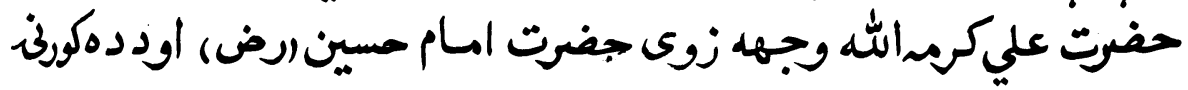

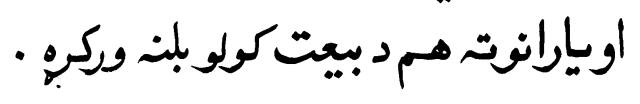

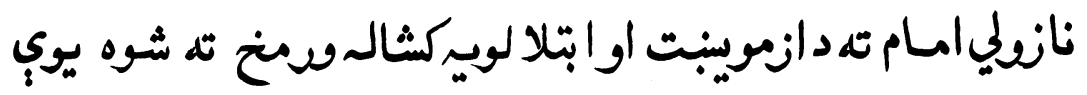

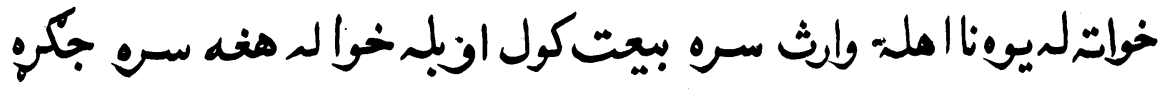

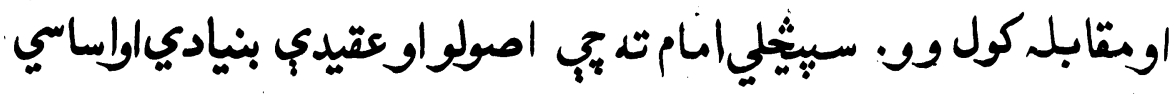




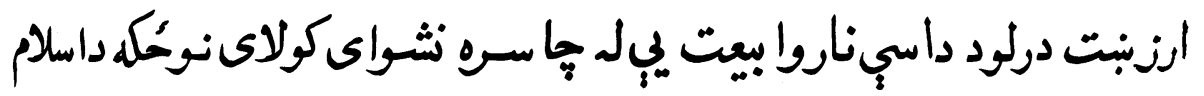

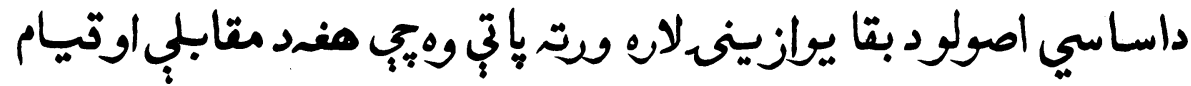
لاره وه .

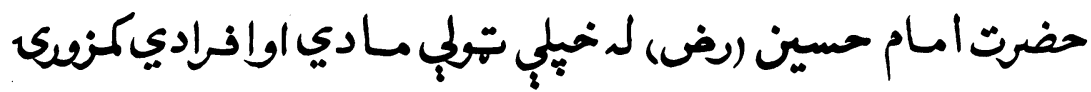

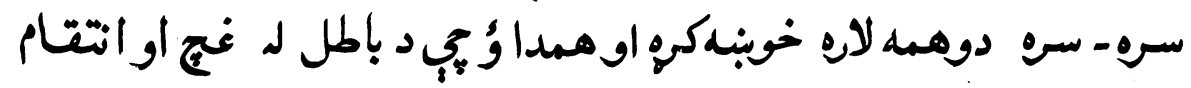

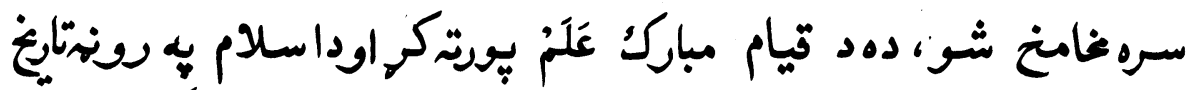

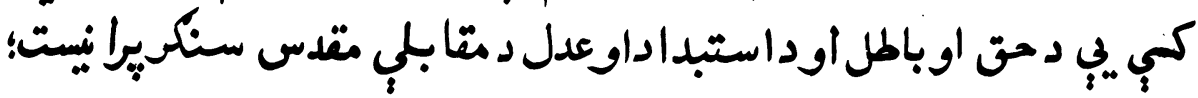

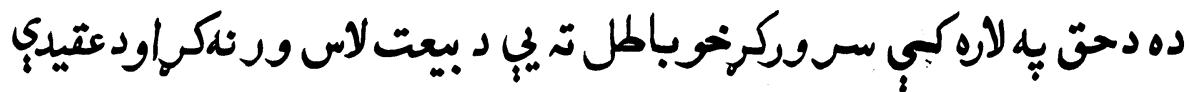

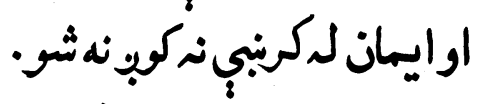

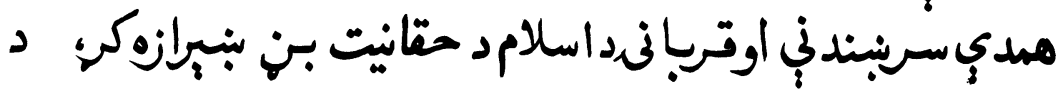

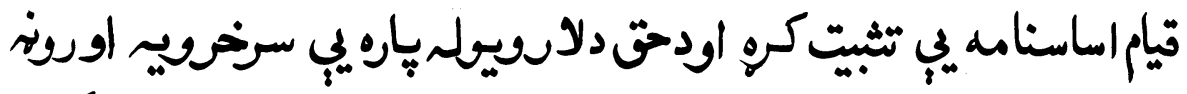

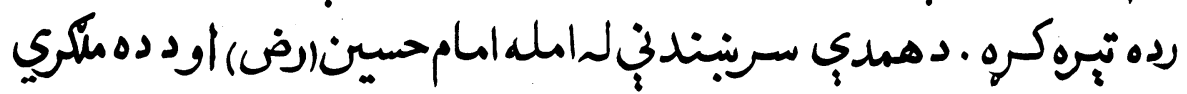

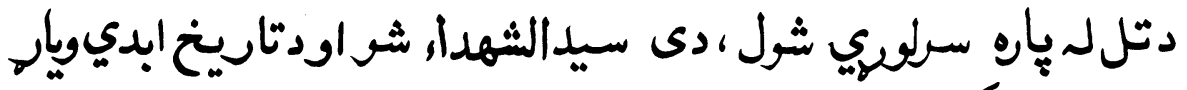

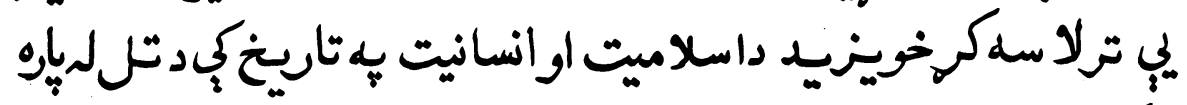
عكوم اومنغقرشو - مئر

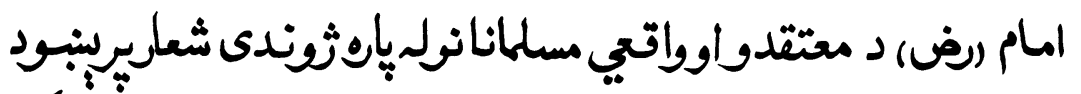

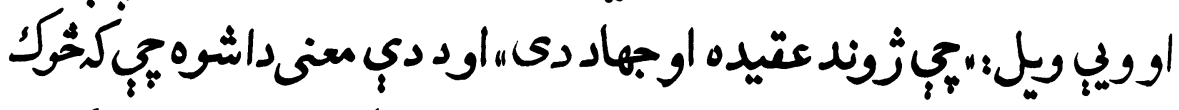

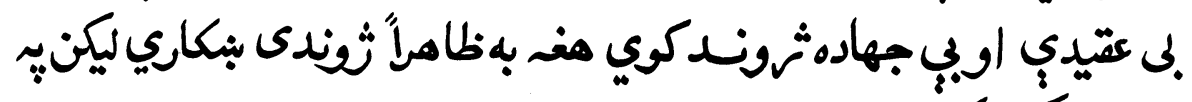

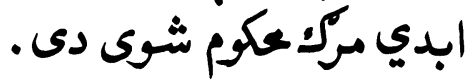




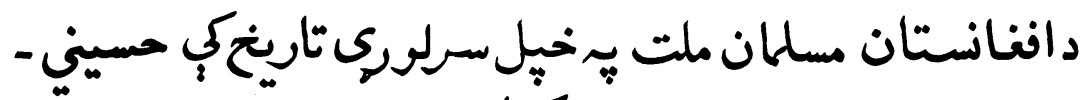

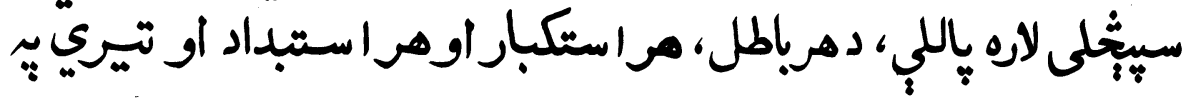

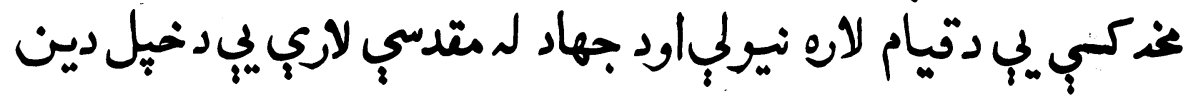

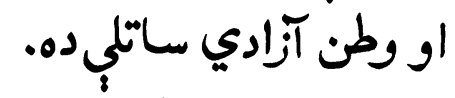

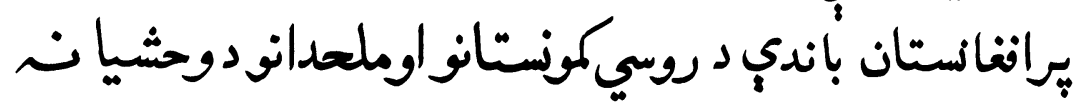

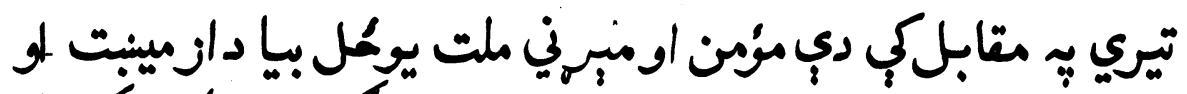

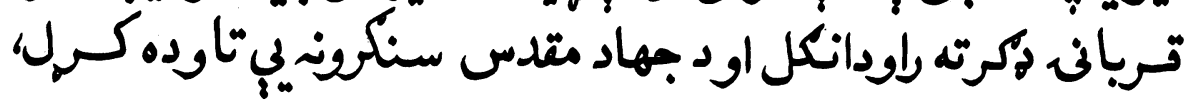

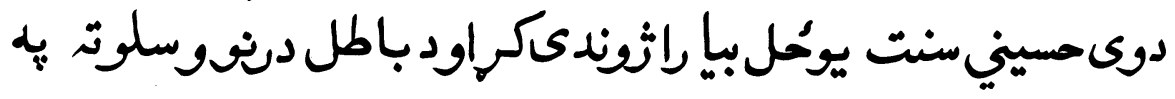

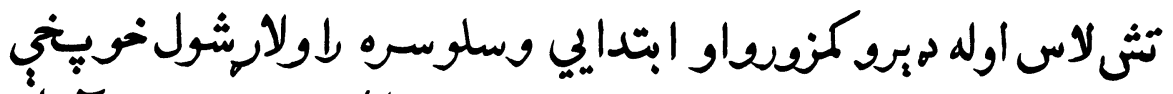

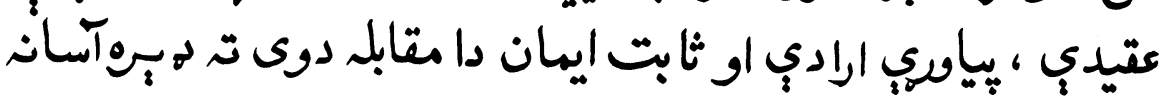

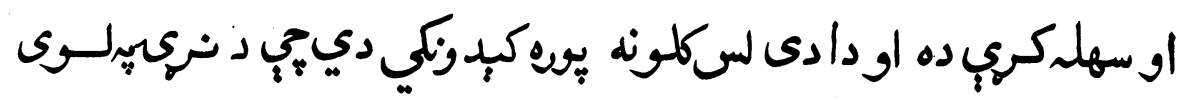

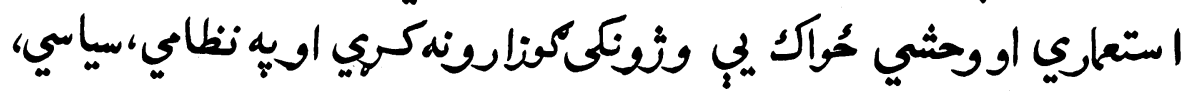

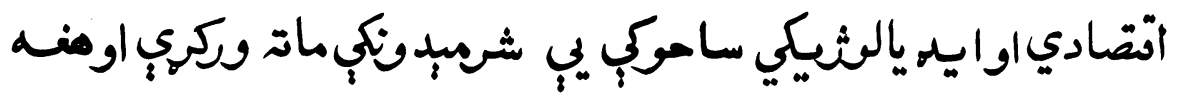

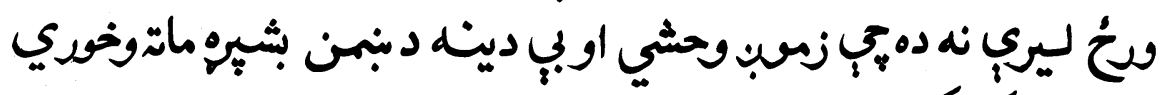

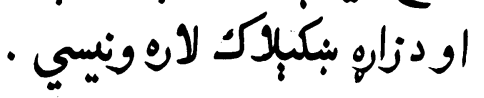

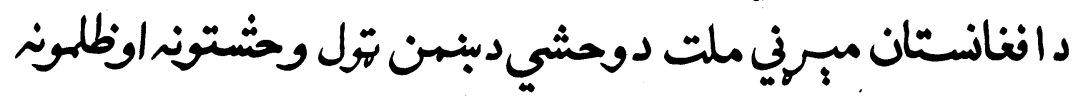

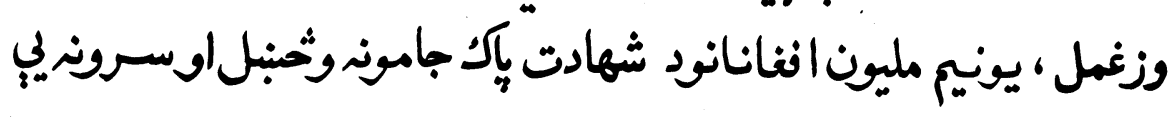

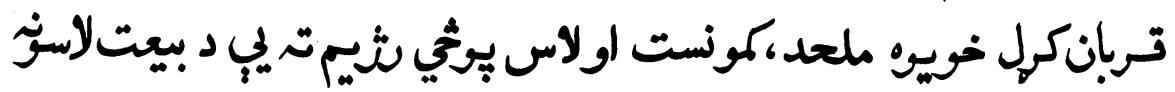

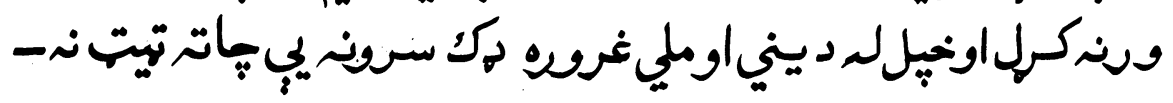


$\Delta$

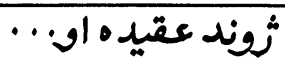

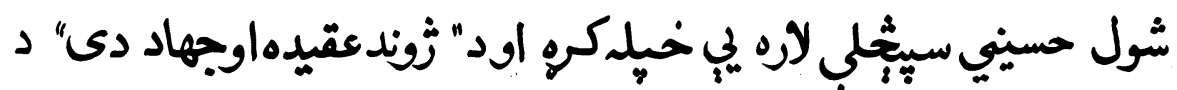

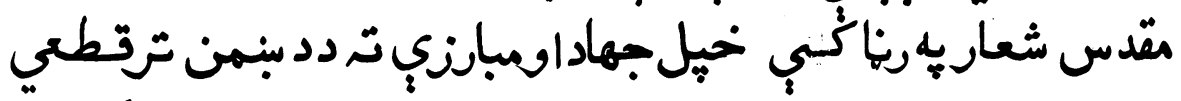

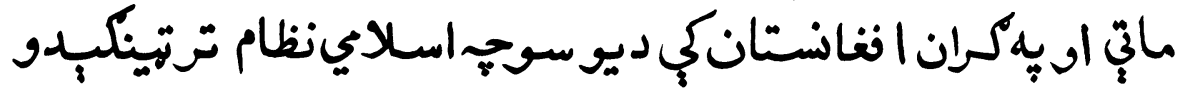
يوري قاطعان دورام وسكوي:

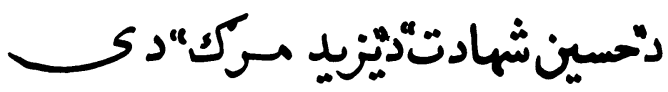

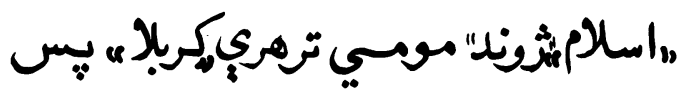

"Q ") 
حبيب الهه رئع
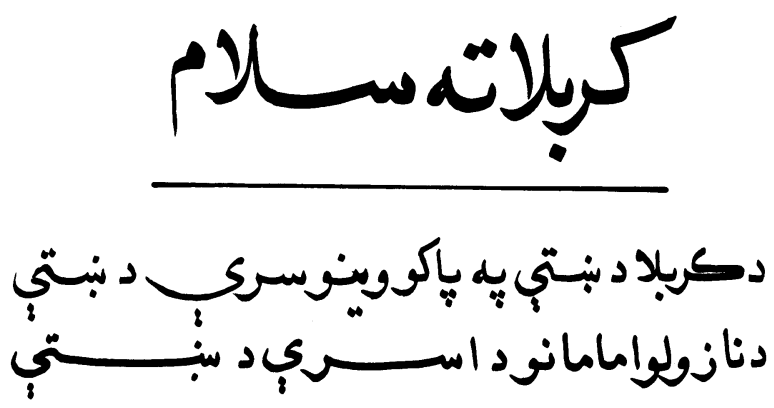

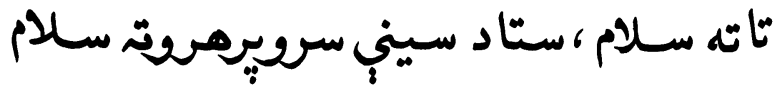

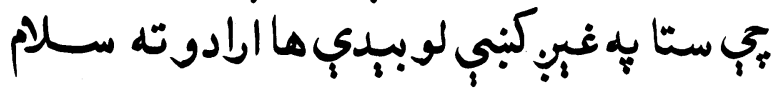

$$
\begin{aligned}
& \text { * * * }
\end{aligned}
$$

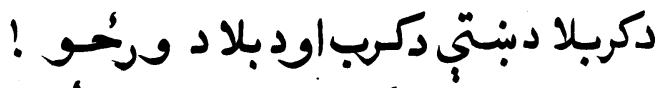

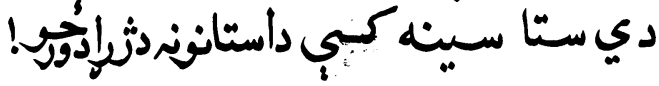

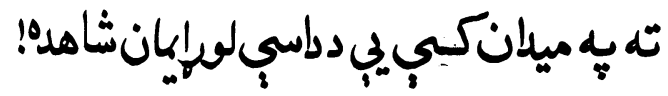

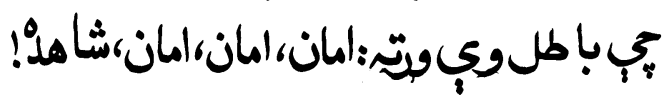




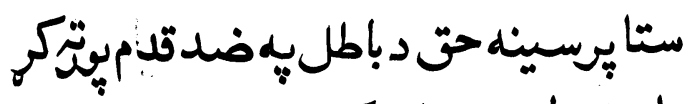

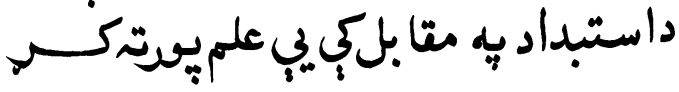

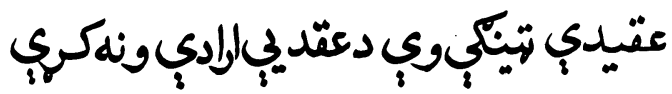

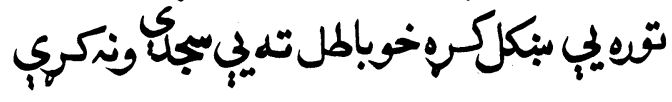
دكربلا دبنستي!ستاياد دي هغه لورسبرونه

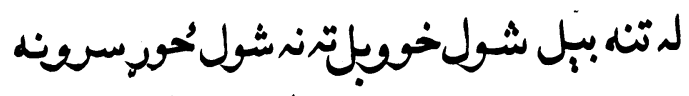
ستإي سيندكيدايهانداسين داستانياتئدى

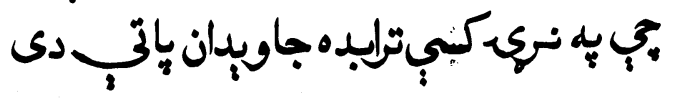

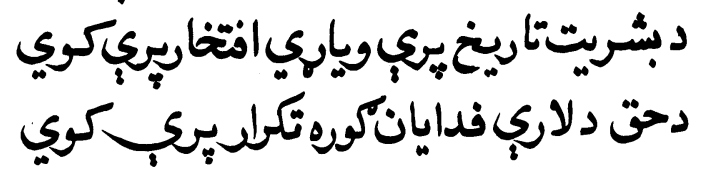

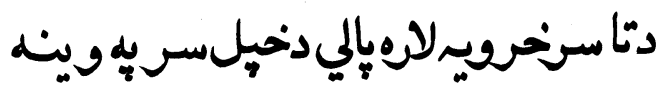

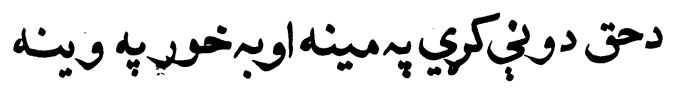
* * * * *

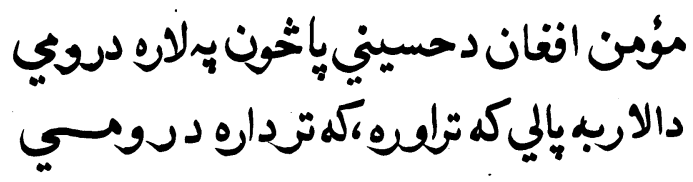

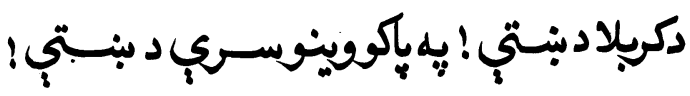

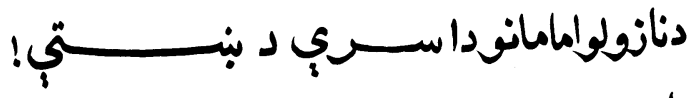

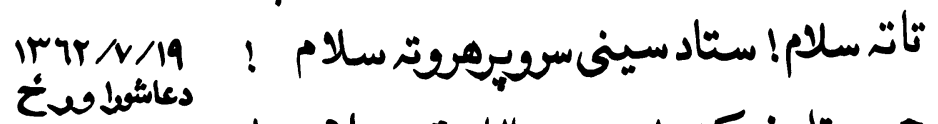

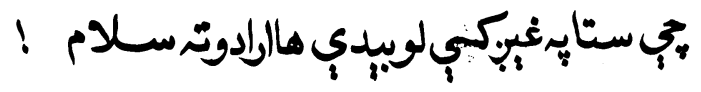




\section{محمدصديق بـرلى}

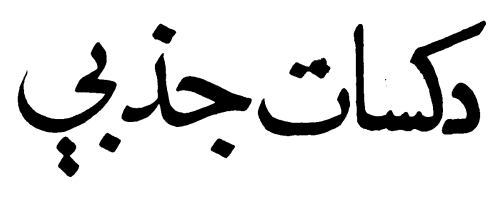

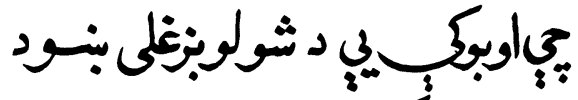

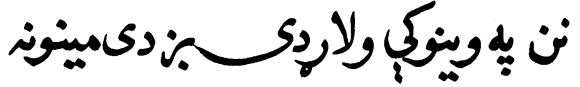

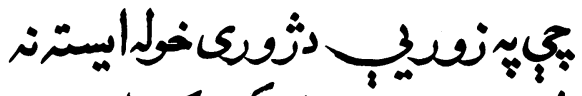

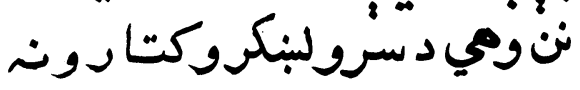

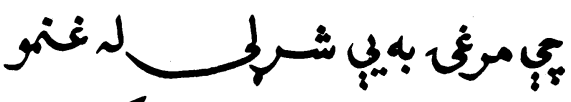

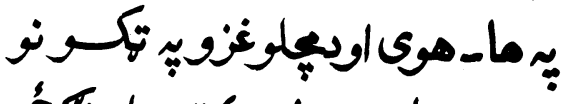

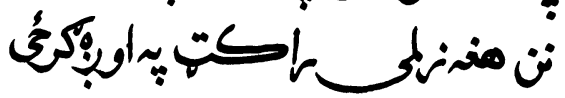
وطن ساتىل تينكونول جازئون 
الحاجمال شنيواري

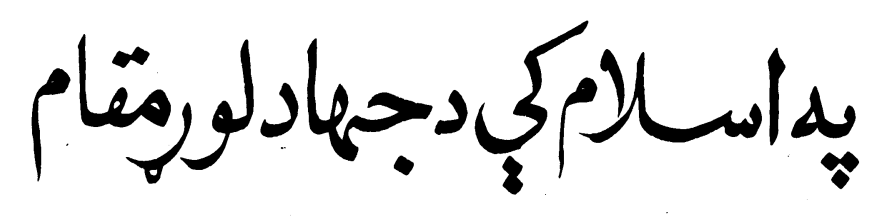

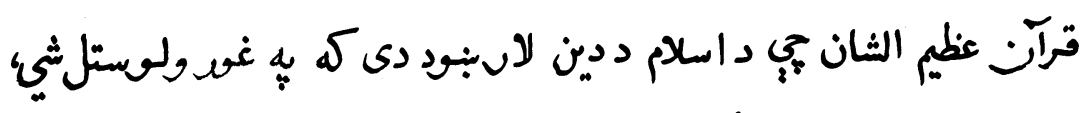

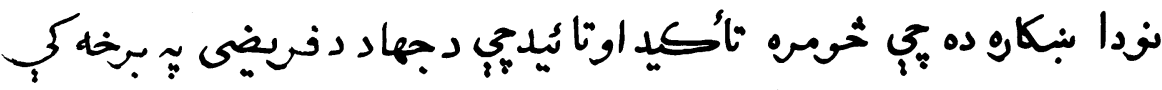

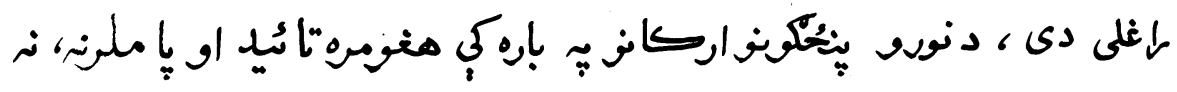
ليدل كُبِي .

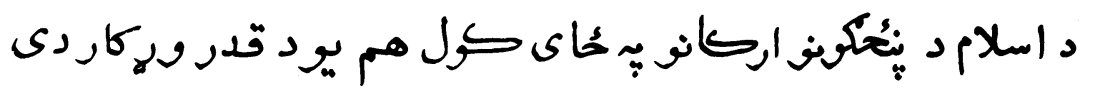

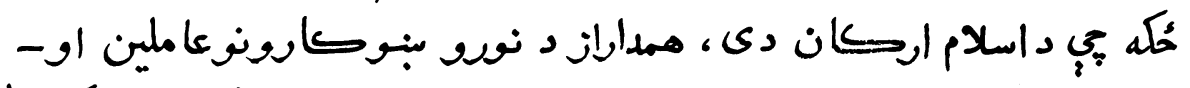

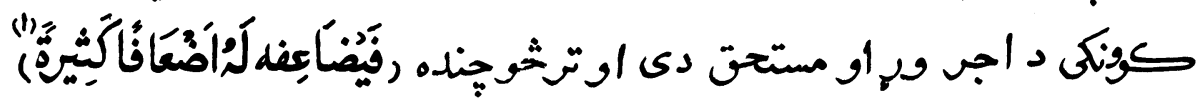

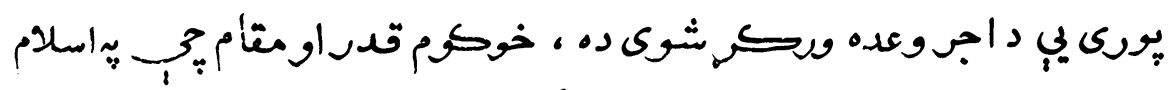

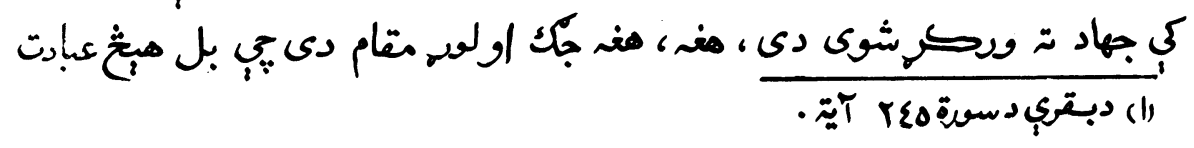




\section{قلم}

او فريضب دغنه متام ته نشي دسبـله .

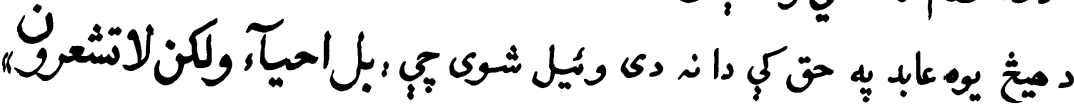

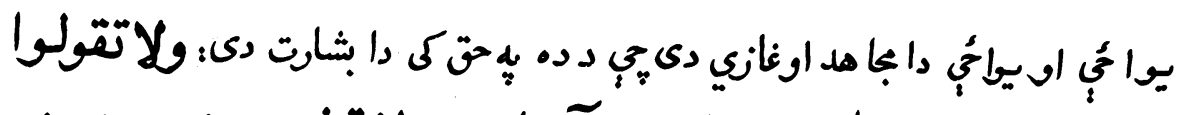

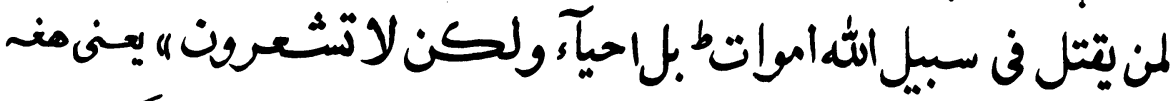

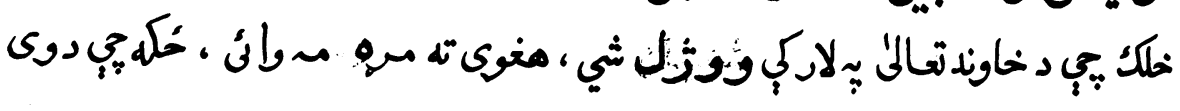

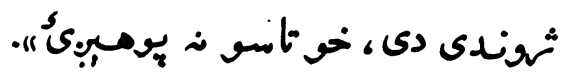

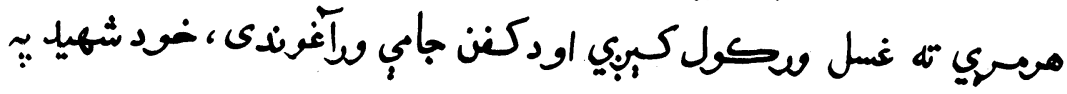

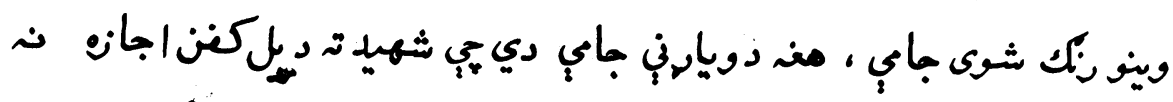

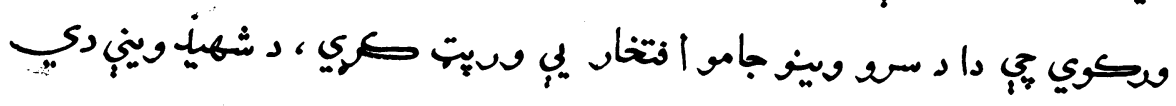

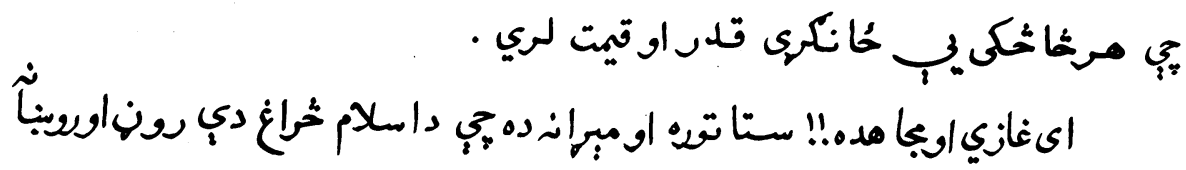

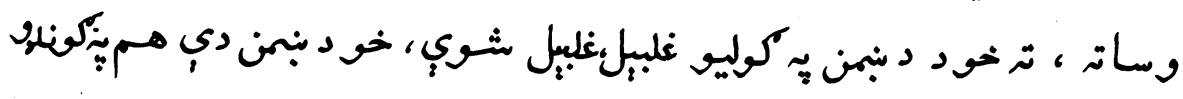

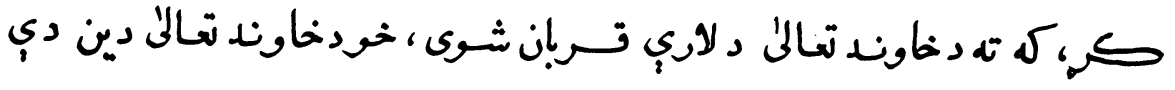

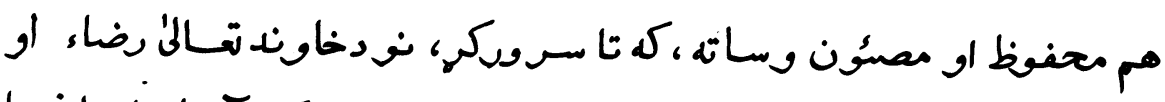

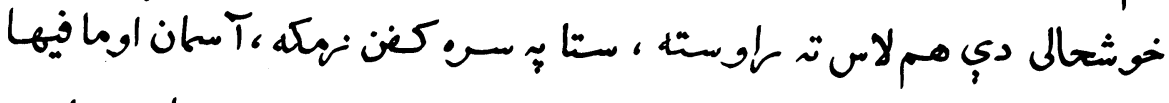

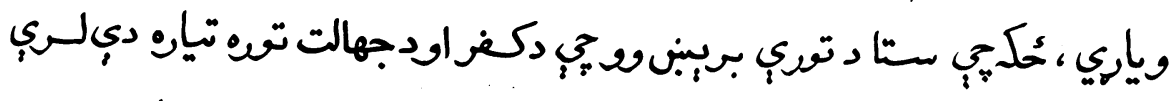

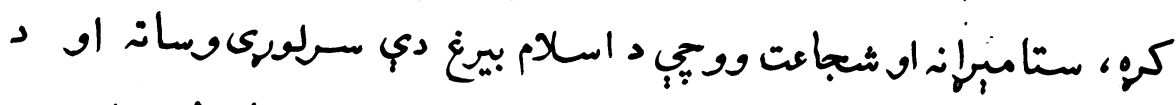

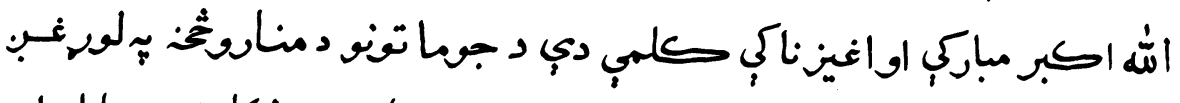

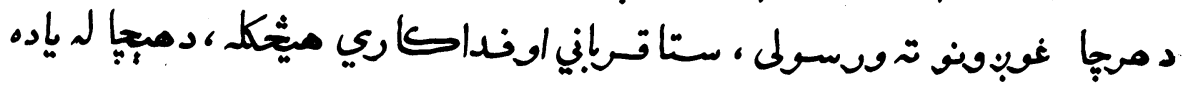




\section{1 ب.....}

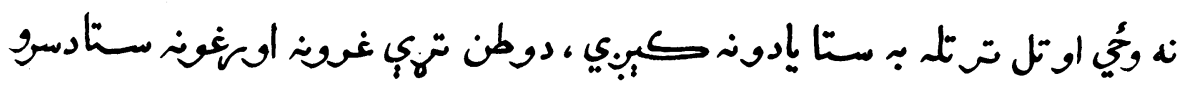

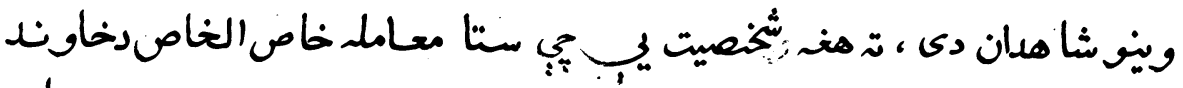

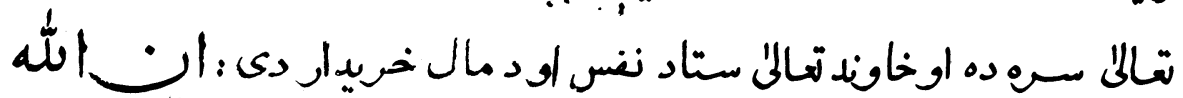

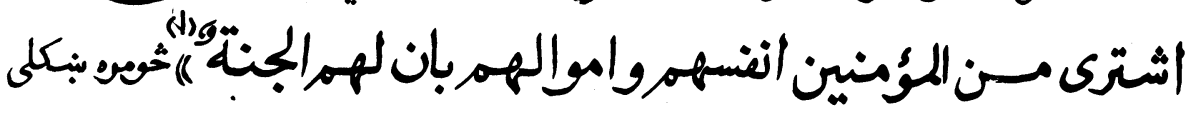

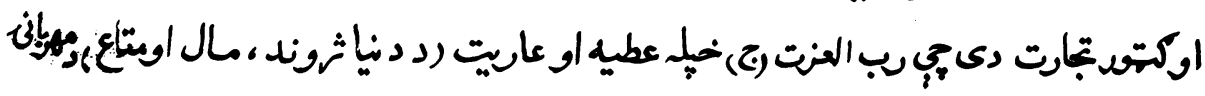

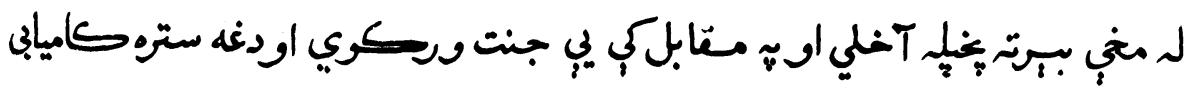

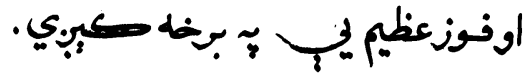

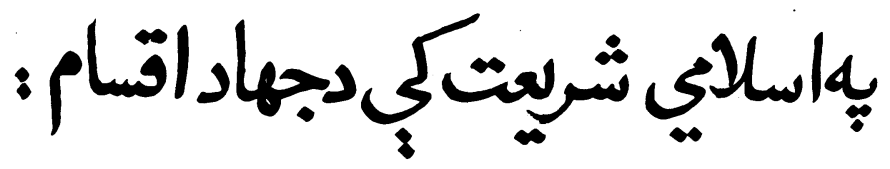

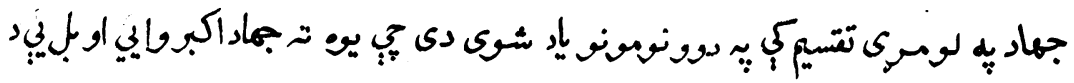

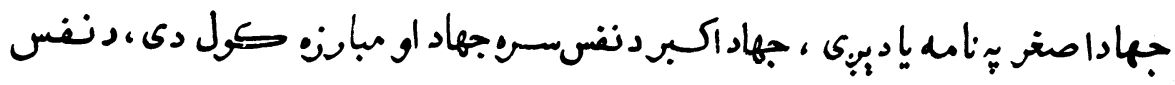

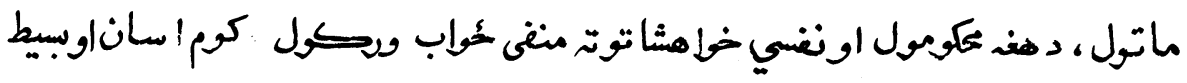

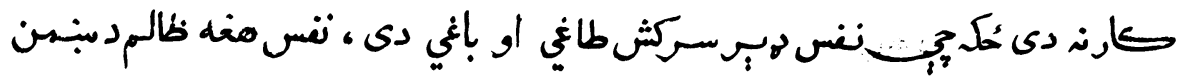

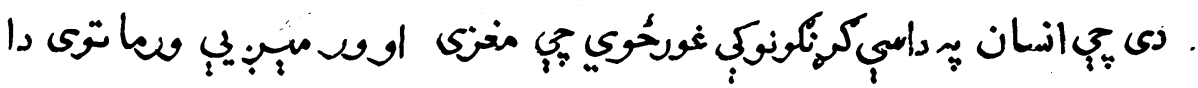

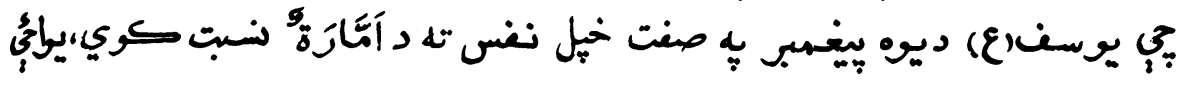

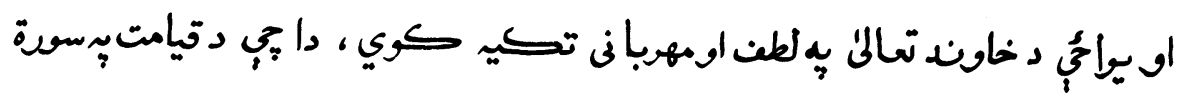

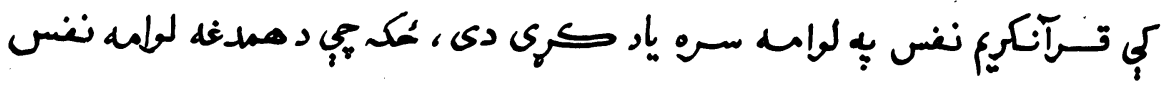

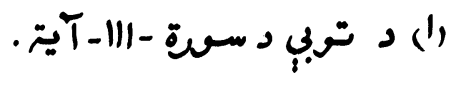




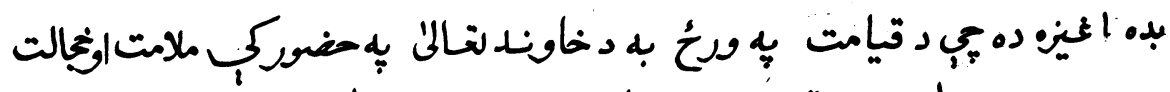

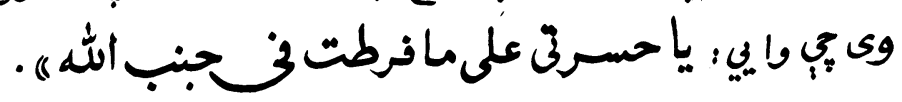

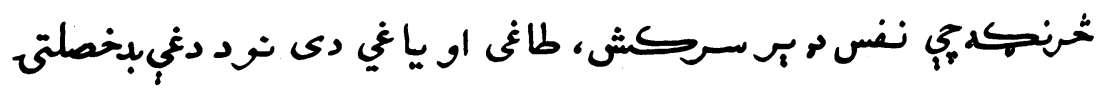

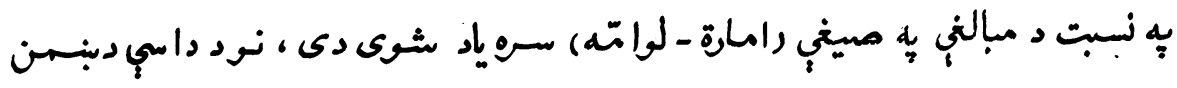

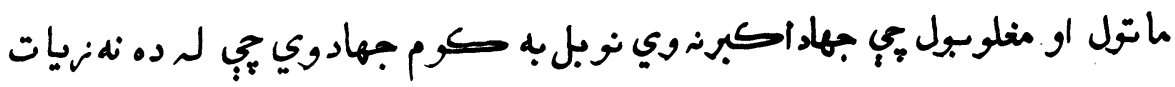

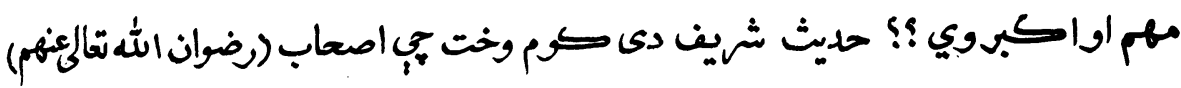

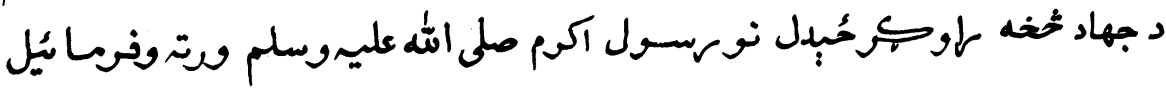

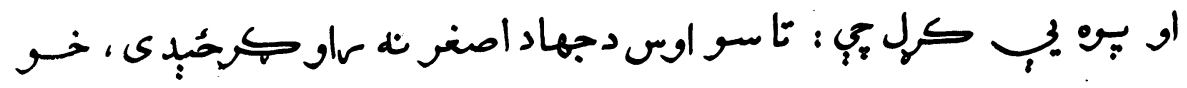

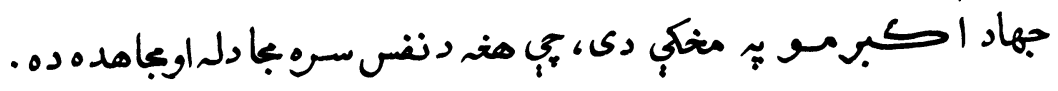

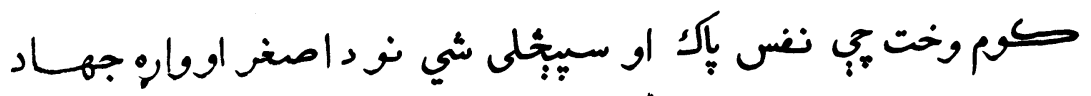

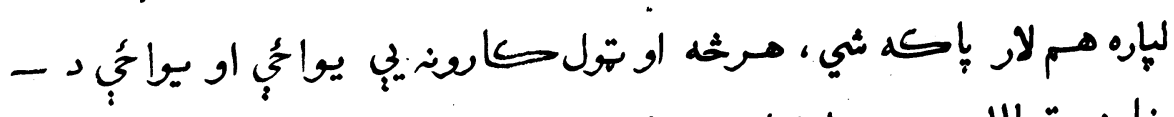

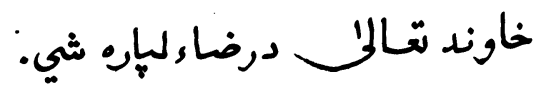

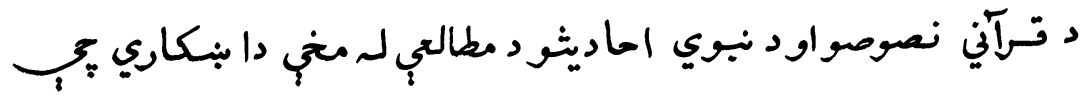

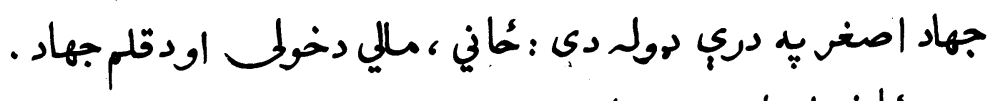

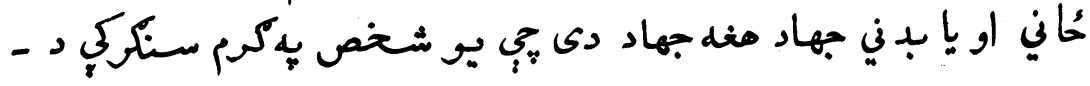

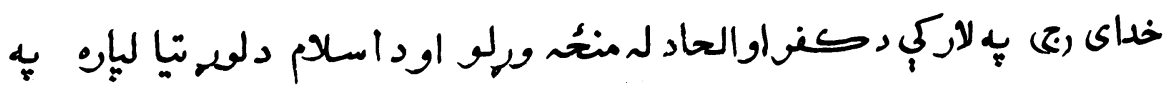

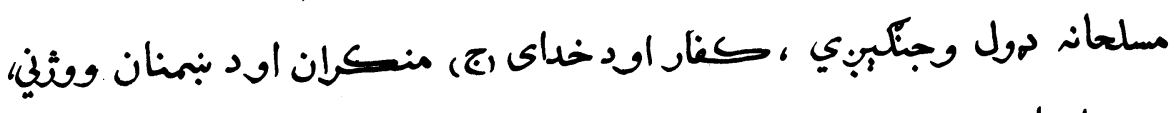

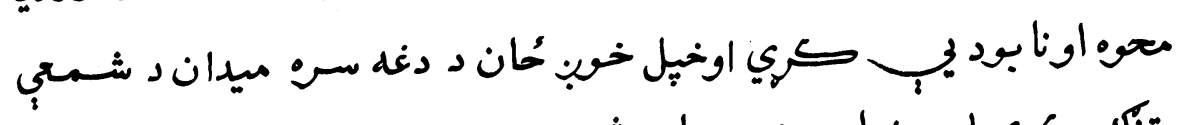
بتنكك كري اود شهادت خوبِ جام وثخبني. 


$$
\text { m }
$$

مالي جهاد دي تخ وايي تي غازيان مجهزكرى ، جنكي وبسلي سازاوسامان

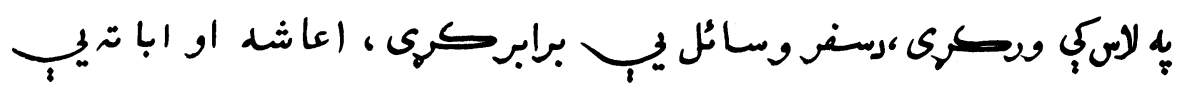

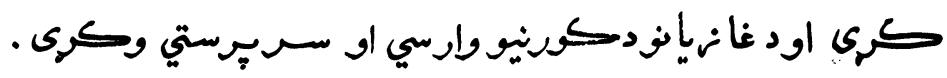

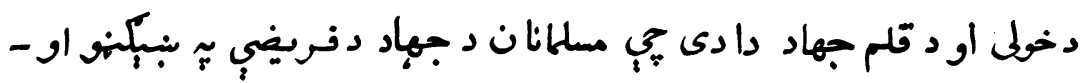

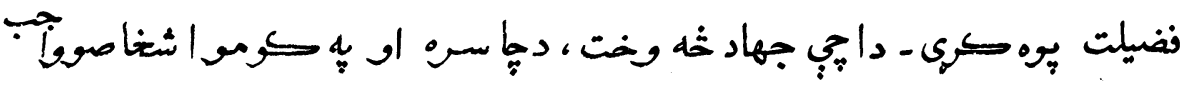

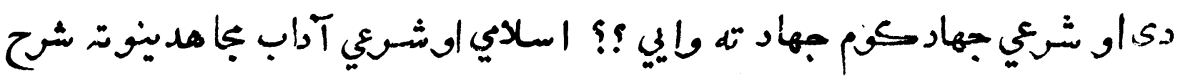

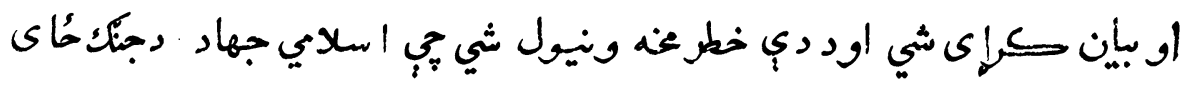

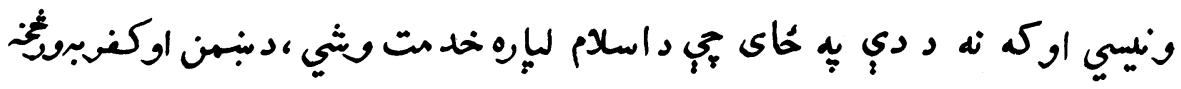
كته وإخلي.

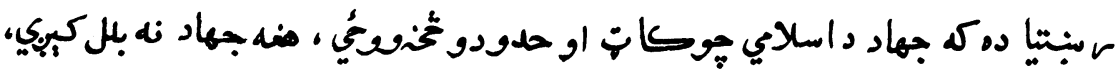

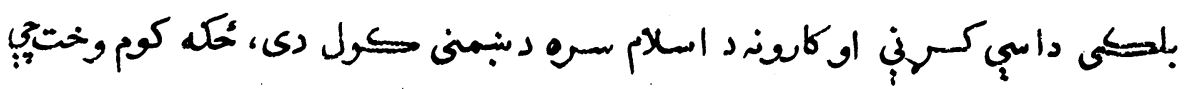

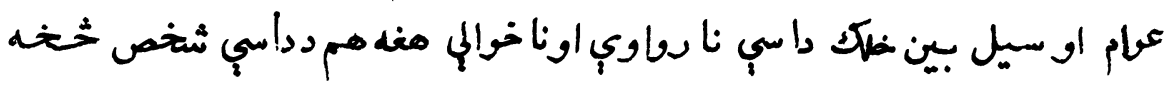

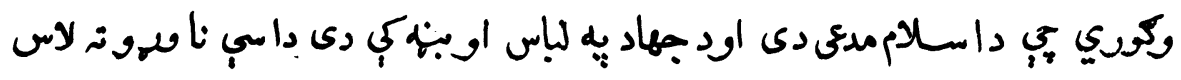

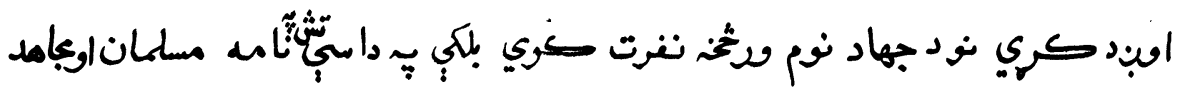

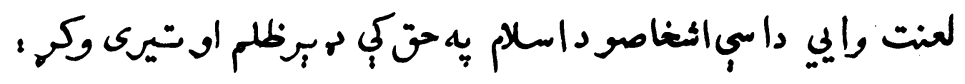

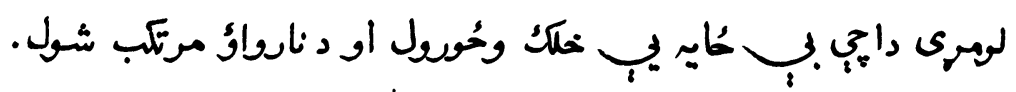

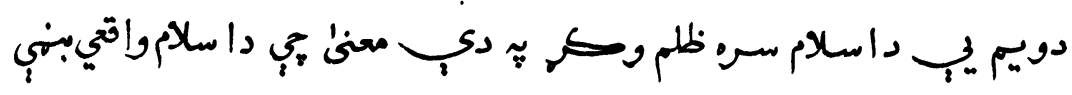

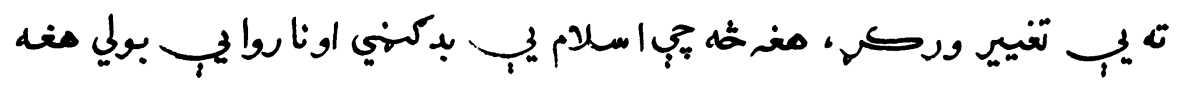

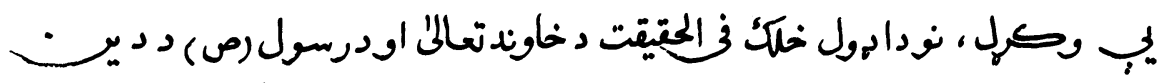


دبنمنان دى اود اسلام دين داسي شغص ته مسلمان نه وإيي ، بكىملعونيّ بولي.

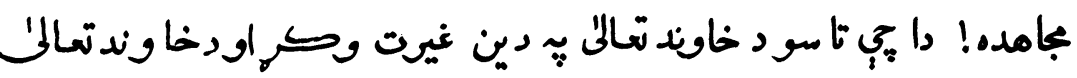

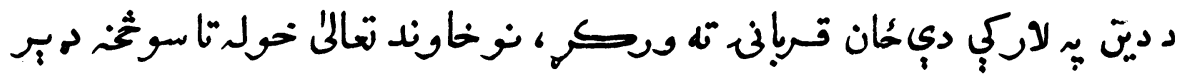

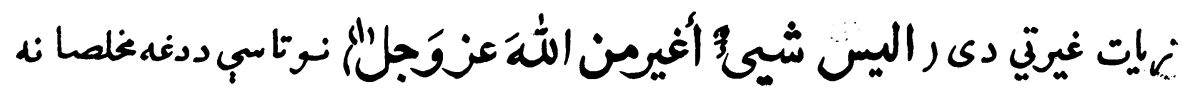

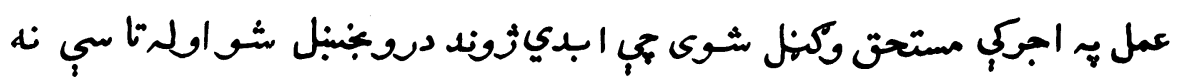

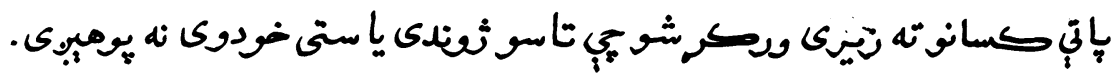

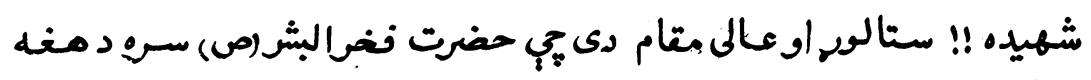

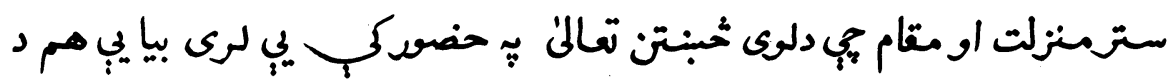

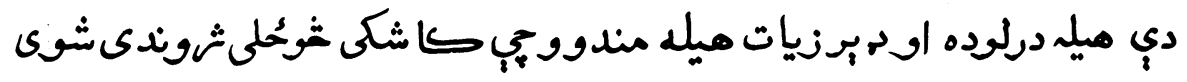

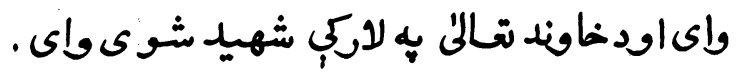

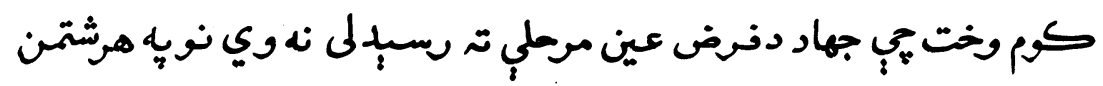

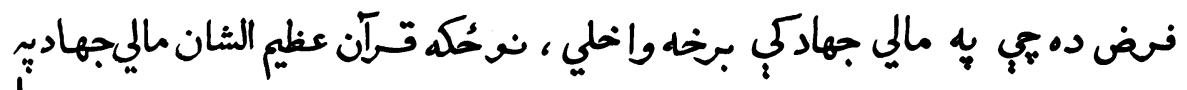

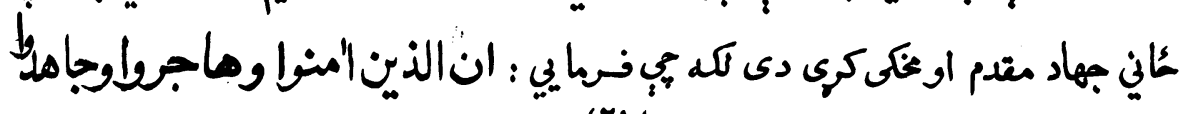

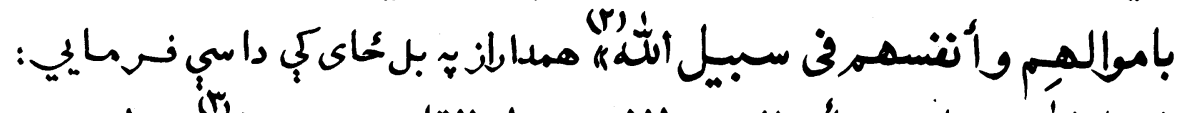

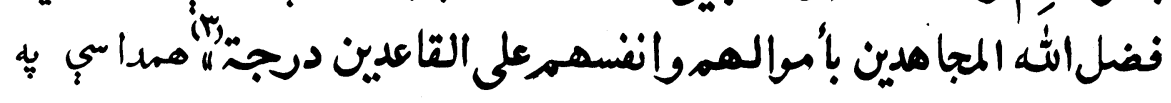

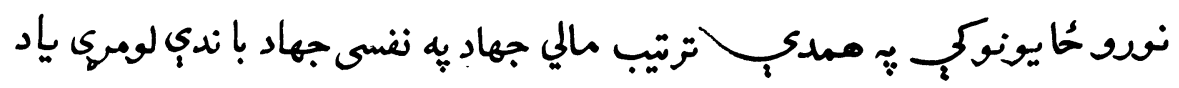

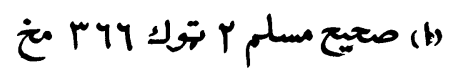
رآي جانفال سورة

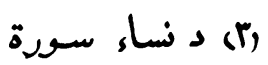




$$
10+\cdots+9
$$

اونكس شـوى دى .

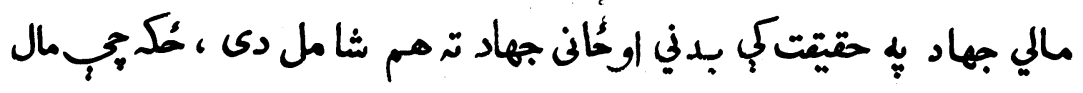

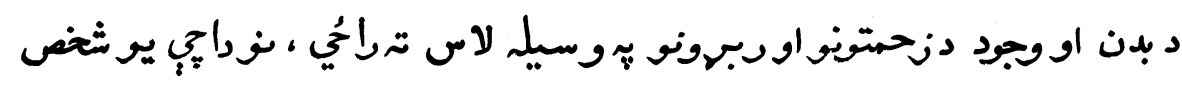

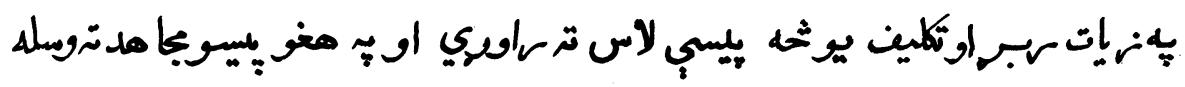

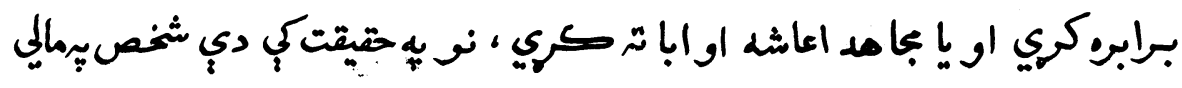

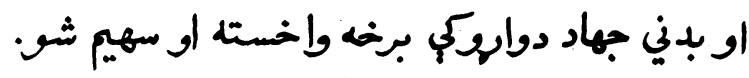

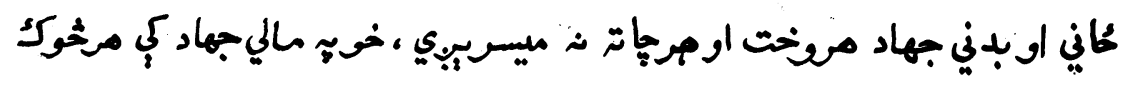

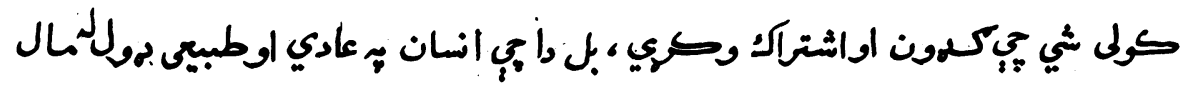

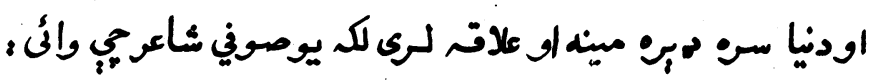

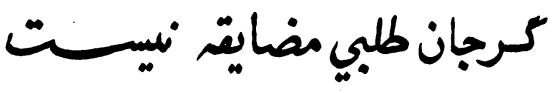

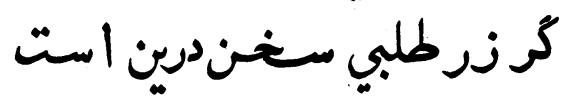

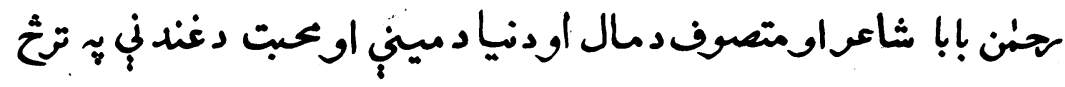
كيخهل بنبهوإي :

بلولوي يه دنيا ديناو إيمان ولِ

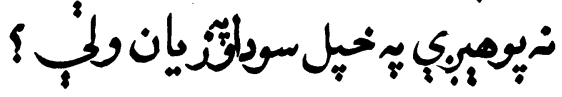

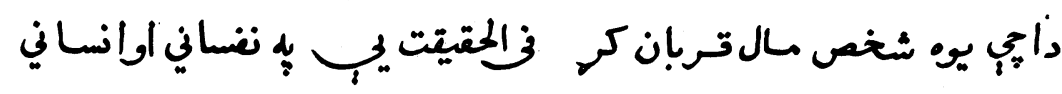

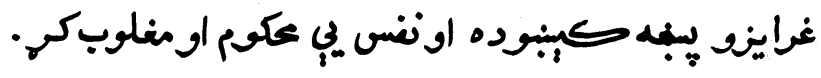

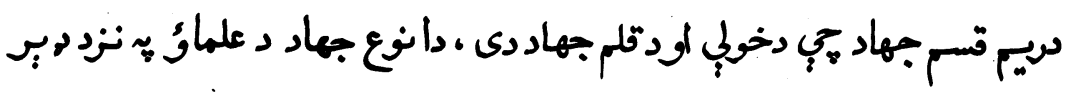

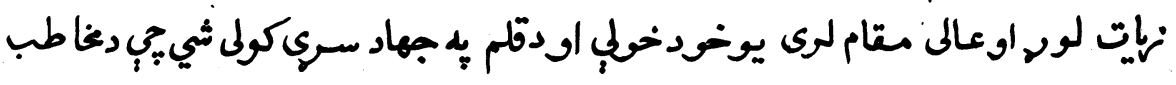




\section{قلم}

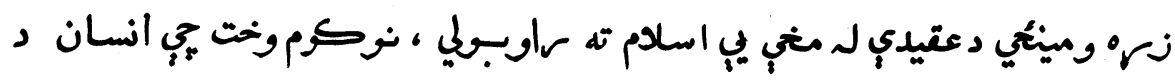

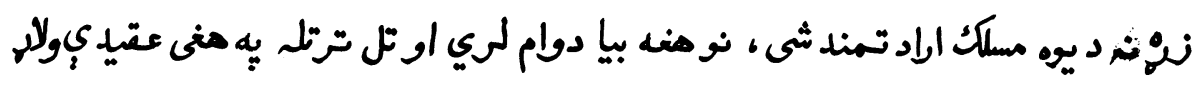

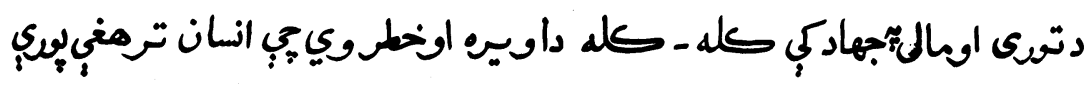

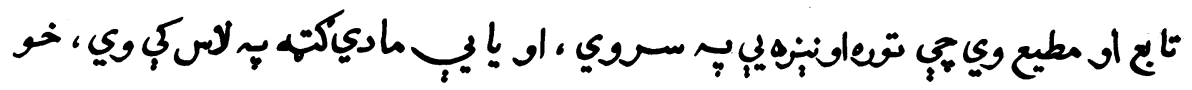

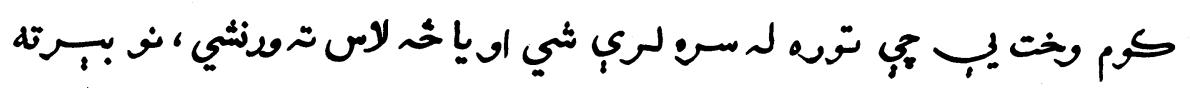

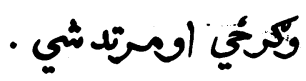

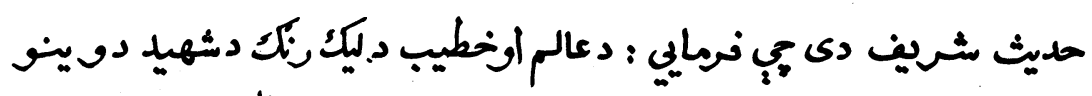

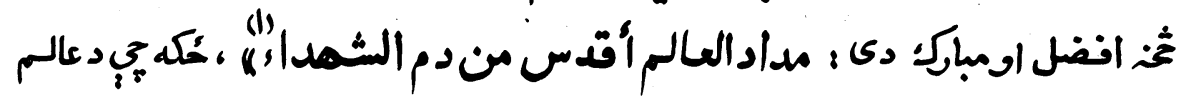

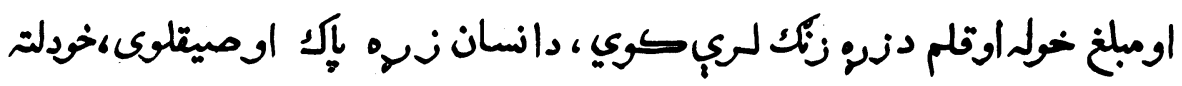

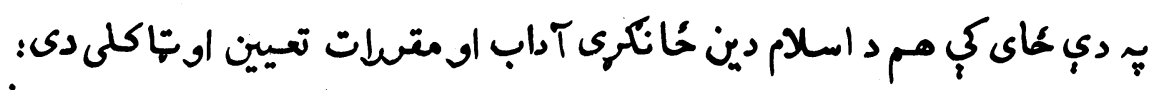

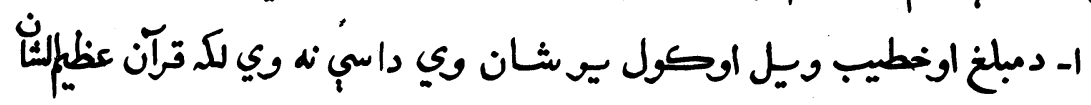

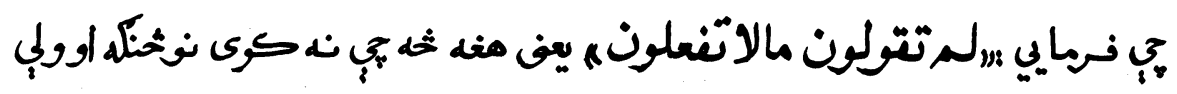
يجي وائن.

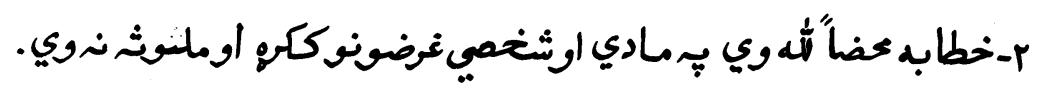

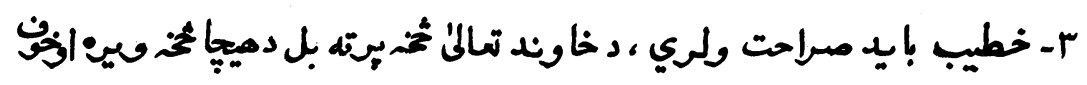

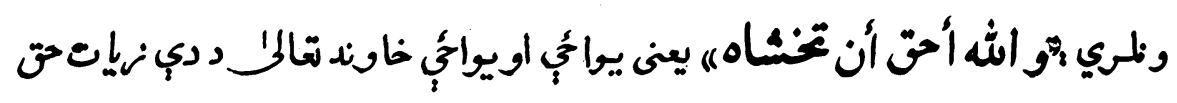

را تردذى شـريف كتابالبهاد. 


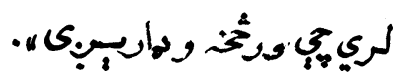

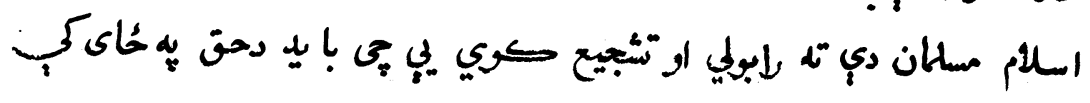

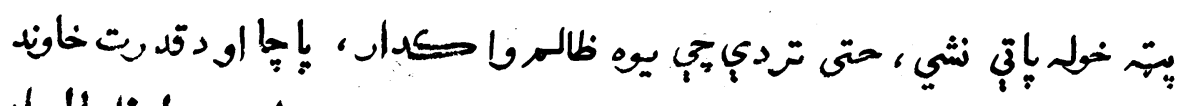

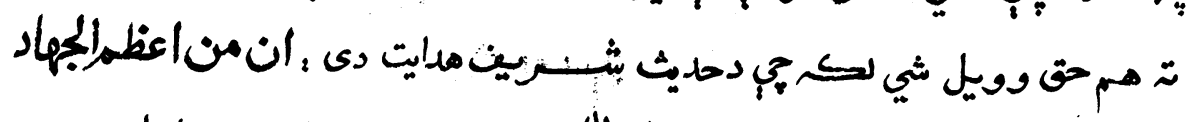

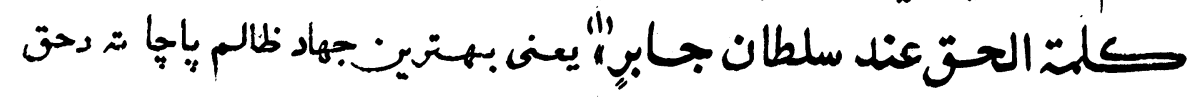

ويل دى .

أ- خطيب با بـ به لويواوعالي ا خلاقو متعس اودتقوى خاوند وي .

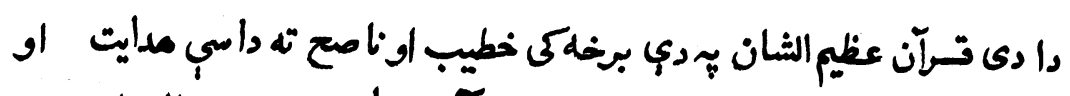

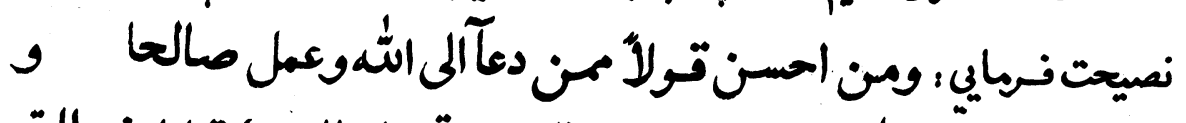

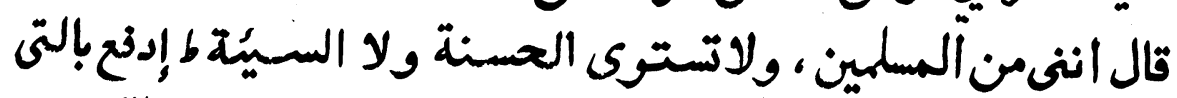

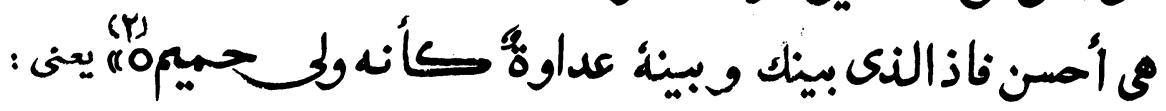

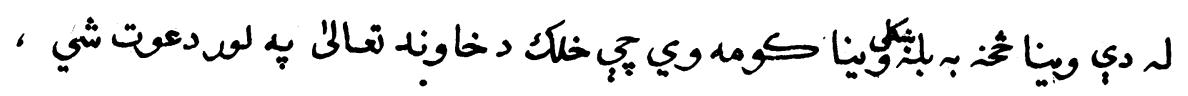

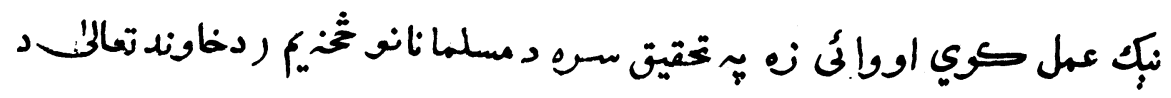

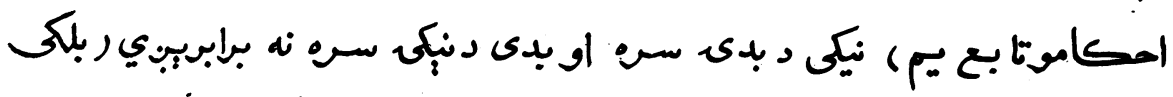

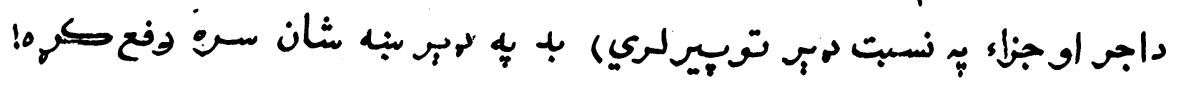

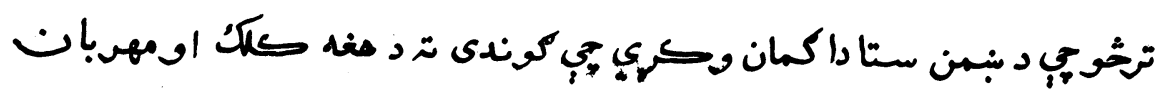

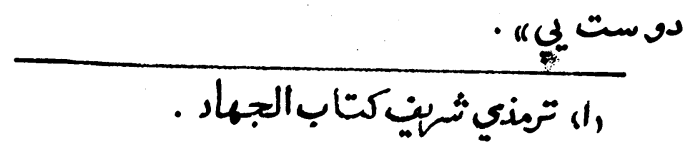

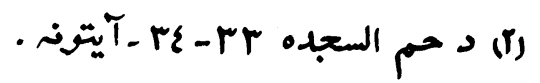




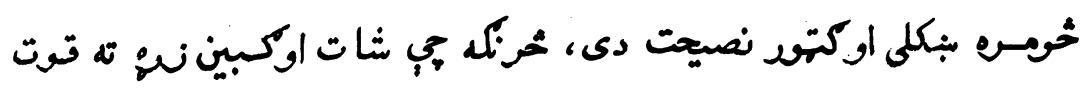

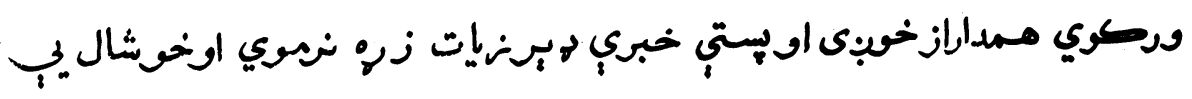
ساتَ

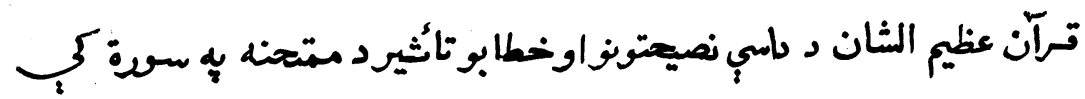

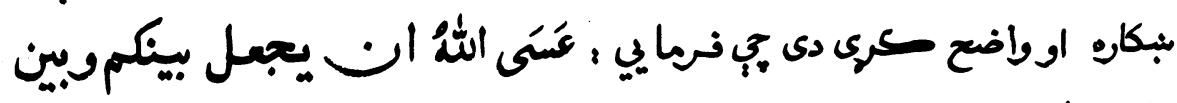

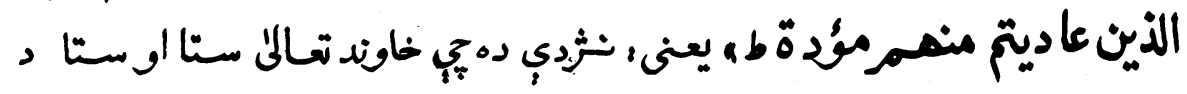

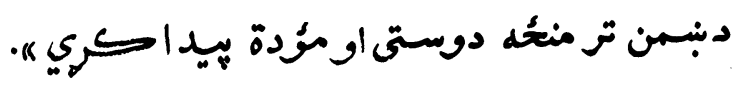

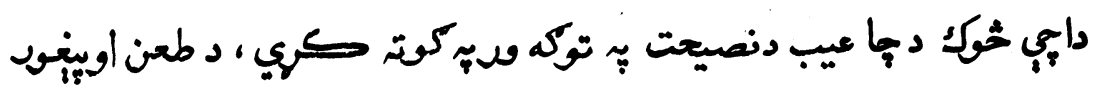

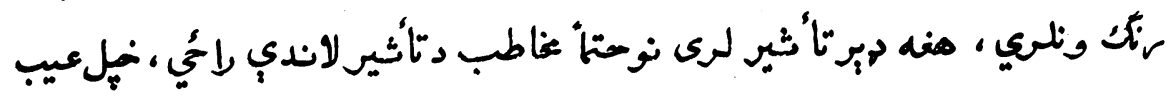

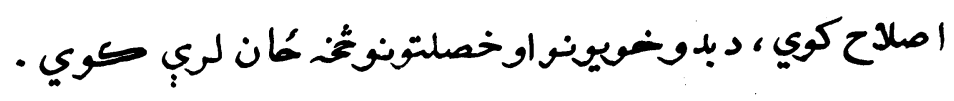

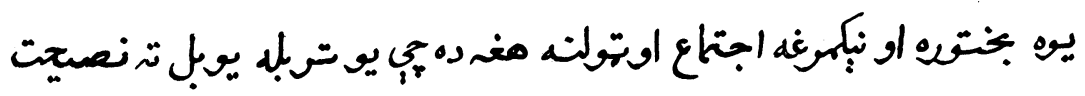
وكي إ يود.بل نصيحت ته غوب ونبي خيل عيوب اصلاح ، نوإتص او -

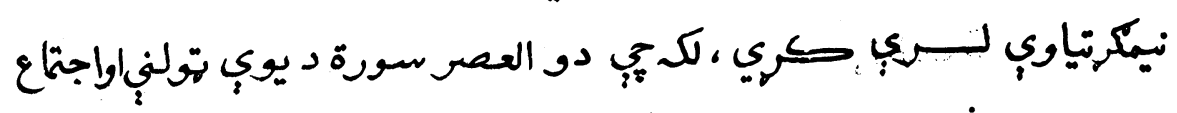

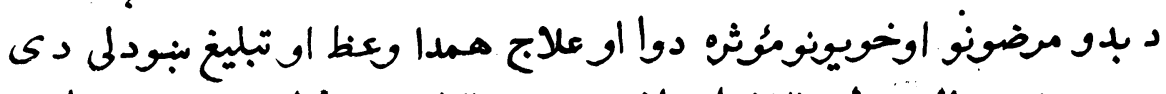

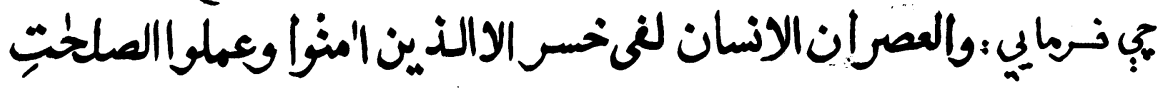

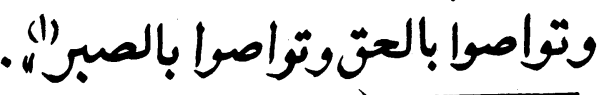

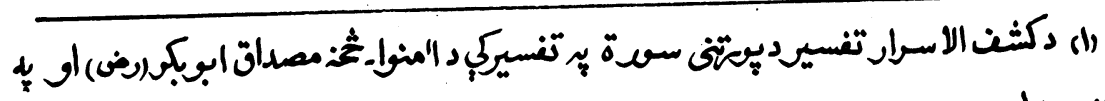

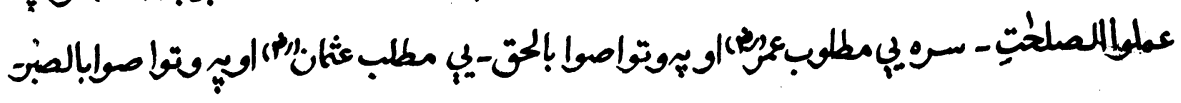

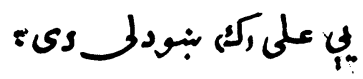




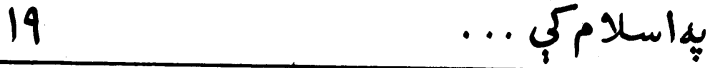

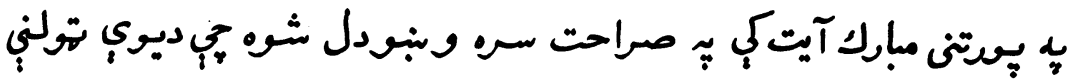

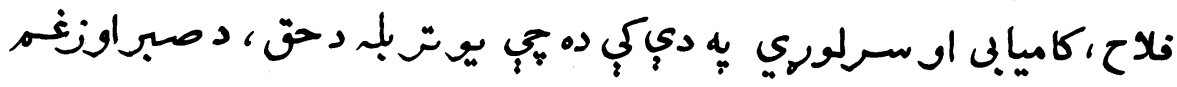

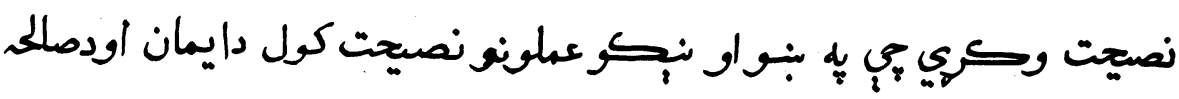

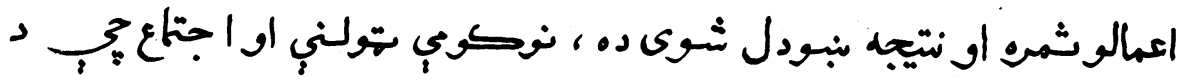

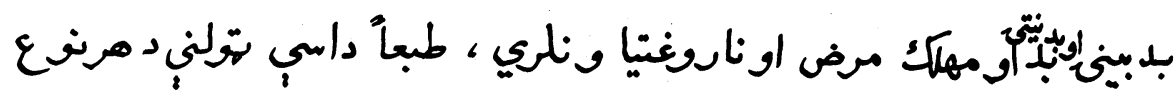

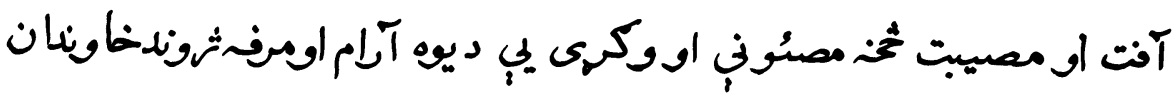

نعسمالمولكــنعمسالنصيs 
سيدشمسلدينجمرح

بمث

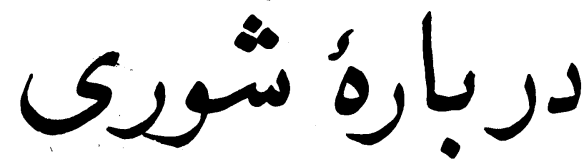

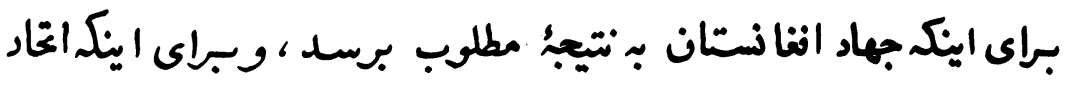

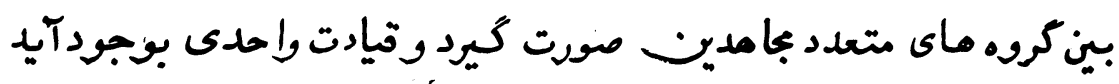

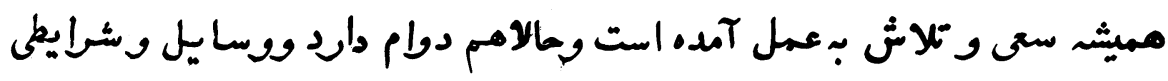

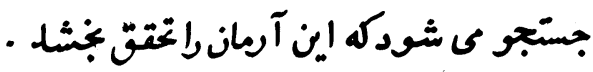

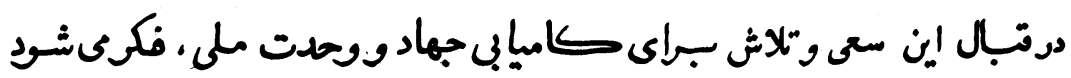

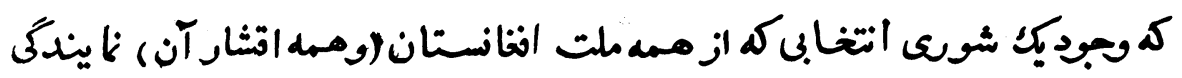

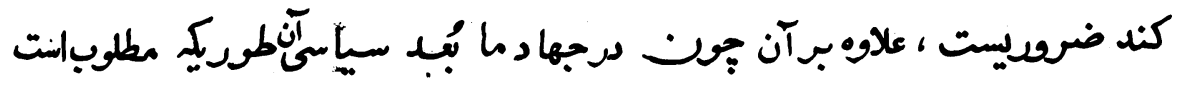

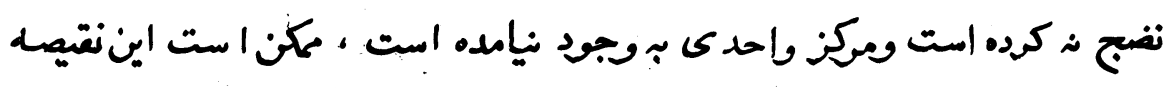

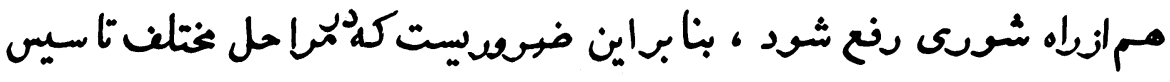

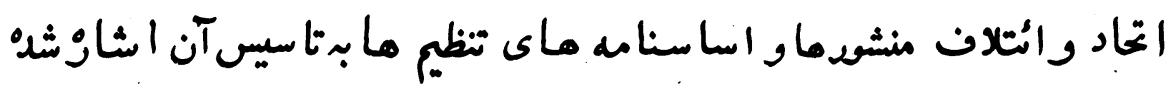

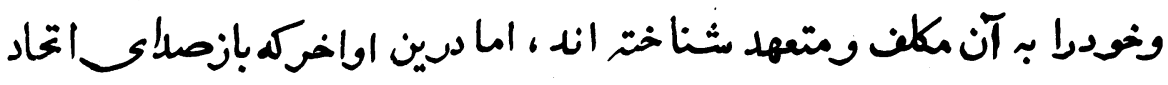




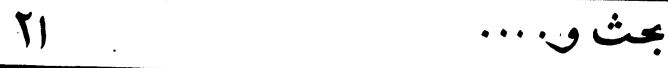

واتعى بين تنظميم ما بلندشده است ، درثاسيس ششوى انتخابى وسستا سرى تردد

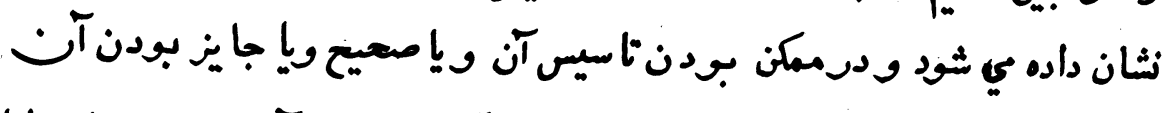

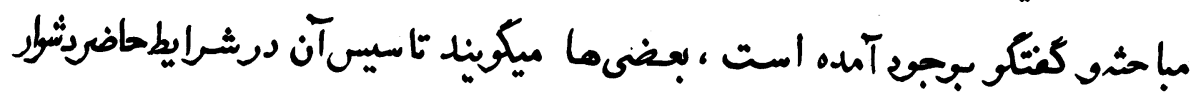

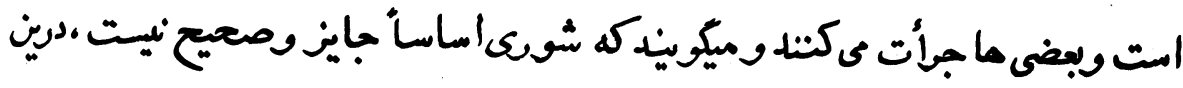

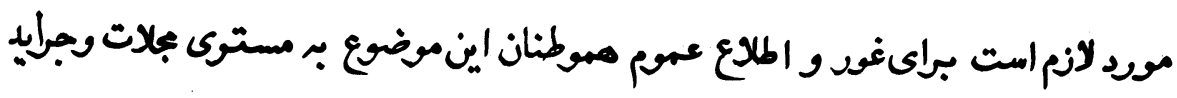

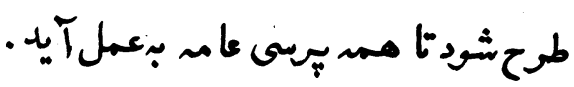

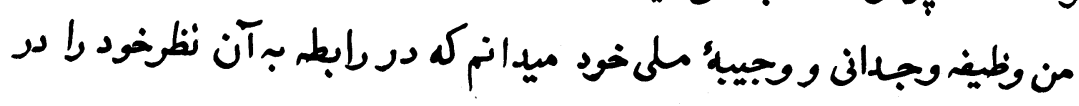

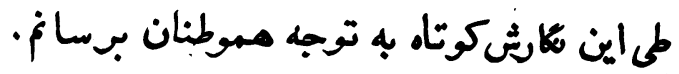

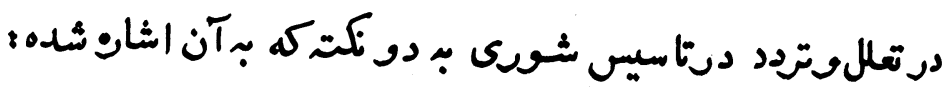

$$
\text { اول اينك دشواراست }
$$

دوم اينك صعيحنيت ، بايدكنت:

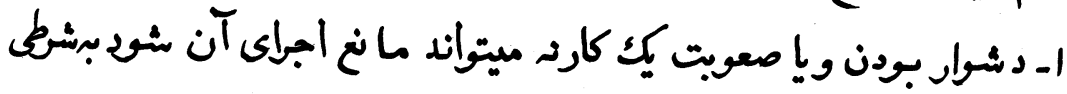

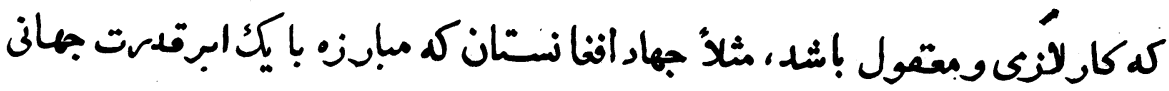
است ،كار اسانى نبود اما جون لانم بود و مم وجيبه ديني وملي مردم انغانستان

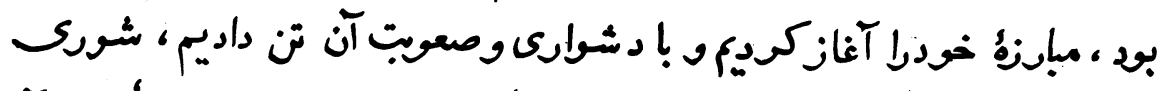

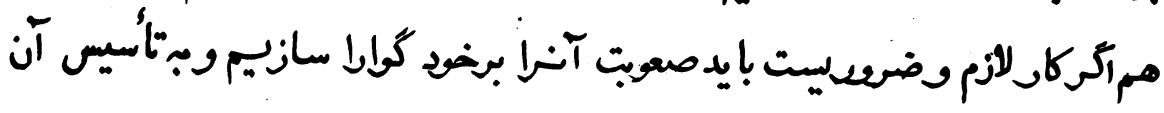
اقدام كنم

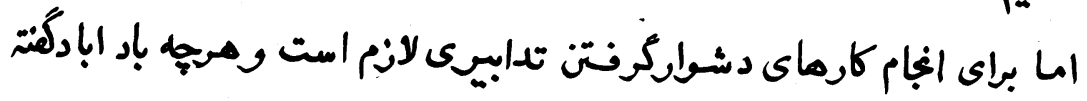

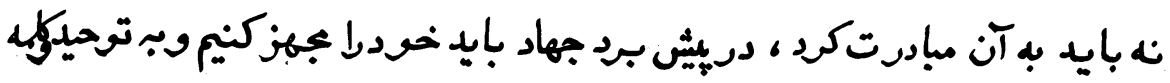


صفوفخود بيردانيم و درتا سيس شورئ بايد لايجه انتغابات رامطابتبرشرايط

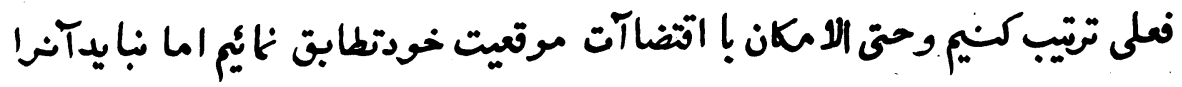
مكلى امالكيم و تركك نئيم.

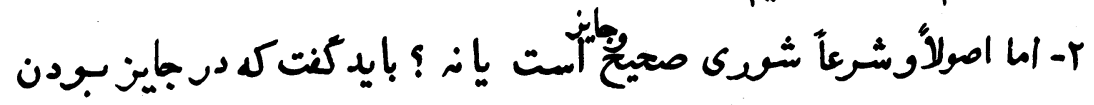

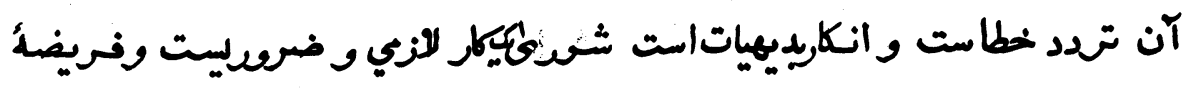

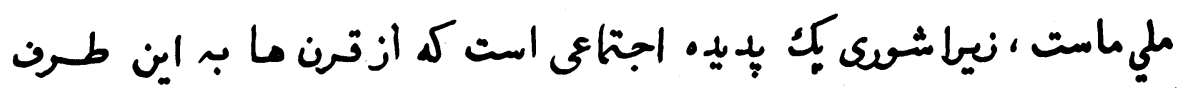

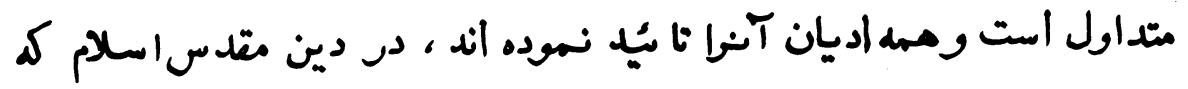

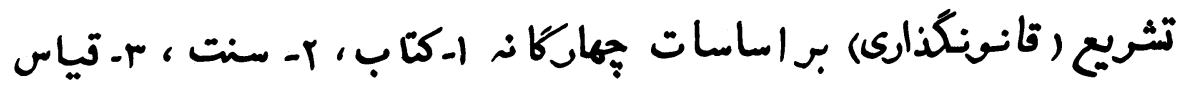

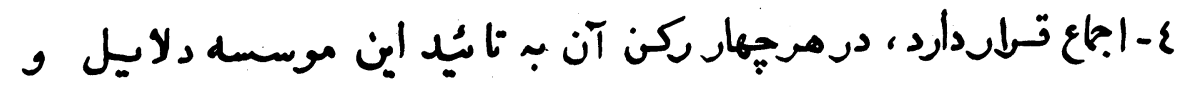

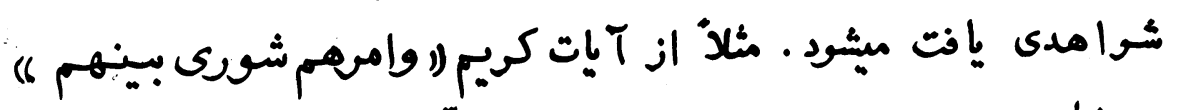

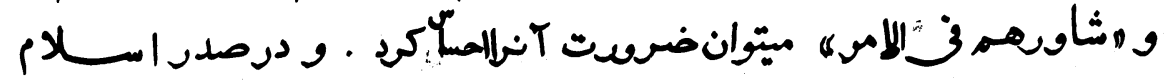

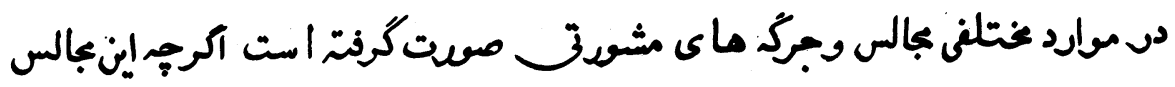

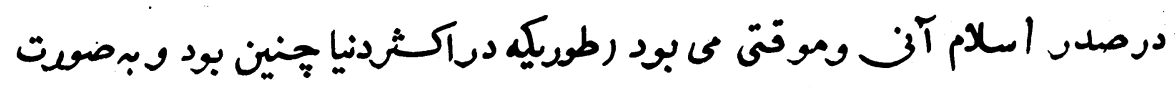

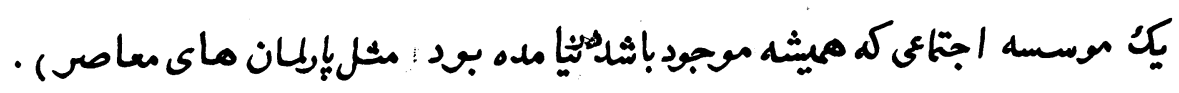

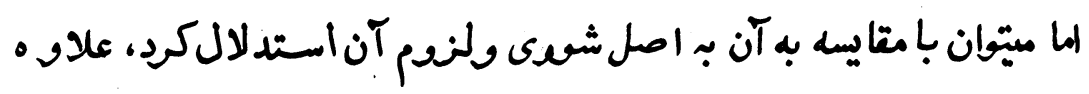

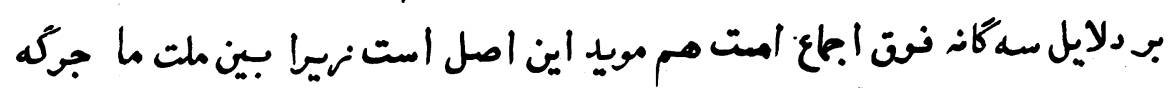

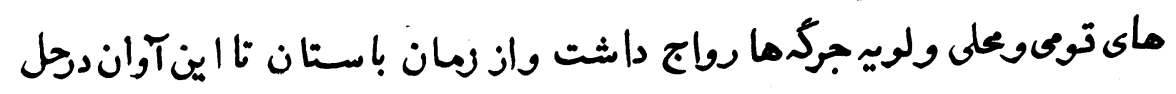

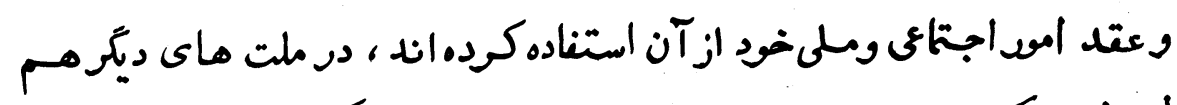

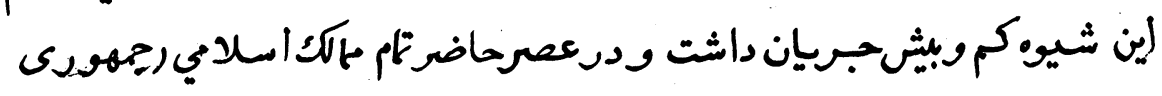




\section{rr}

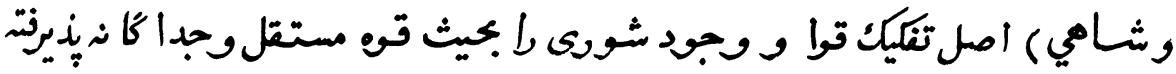

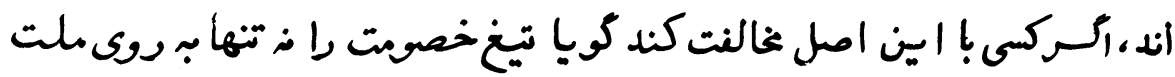
خود بلكد بـعى تمام جهان اسلام كنشيد است .

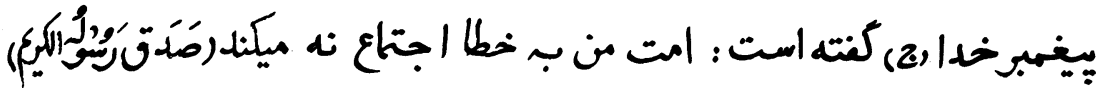

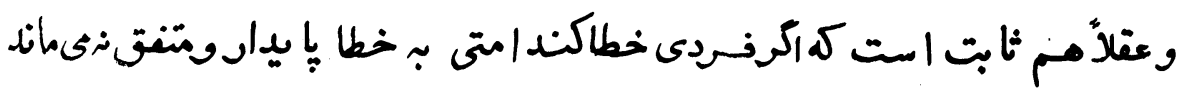

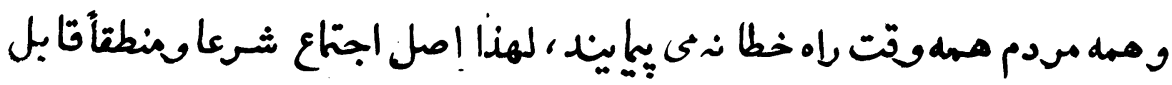

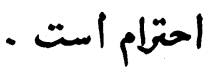

ب تمام اين دلايل ، دليل بنشكُ ديكعى موجموداست آن اصل اباحت است

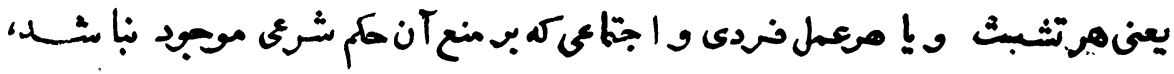

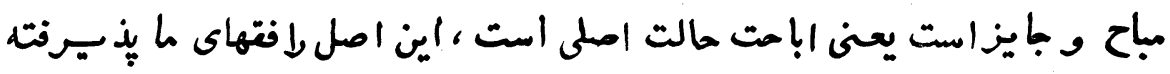

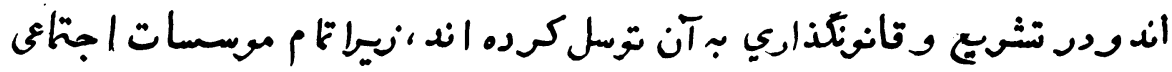

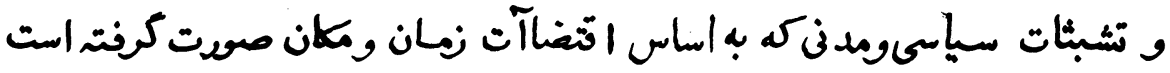
در مايم همين اصل است ، تكا مل و تحول اجتماعي إ همين اصل تضمين مكند

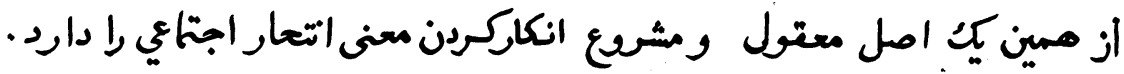

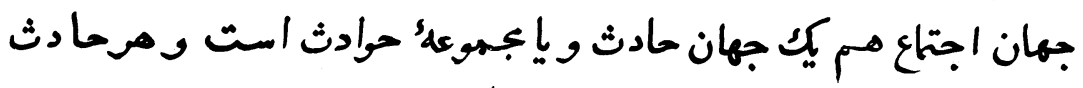

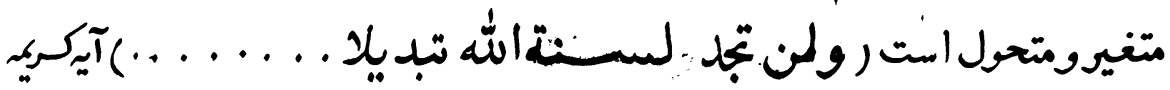

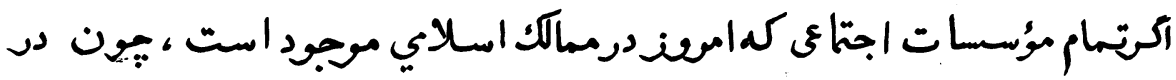

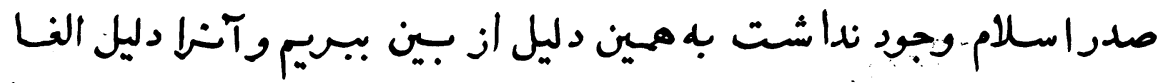

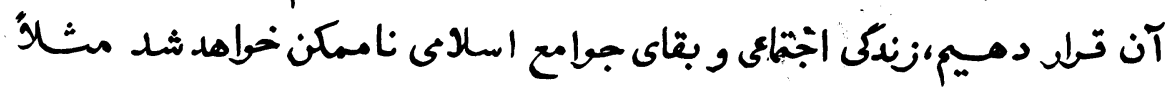




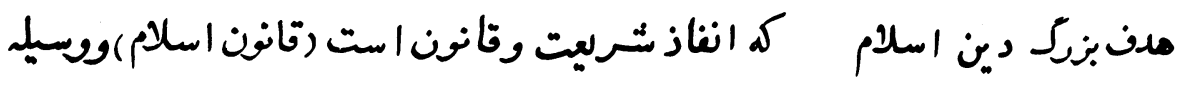

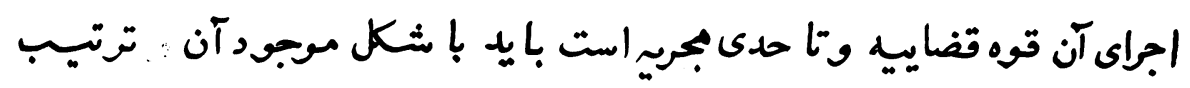

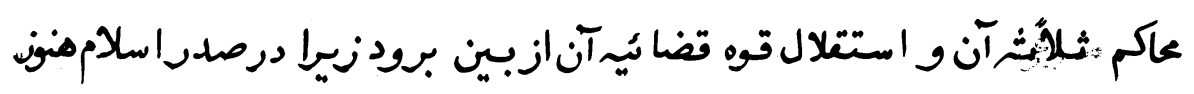

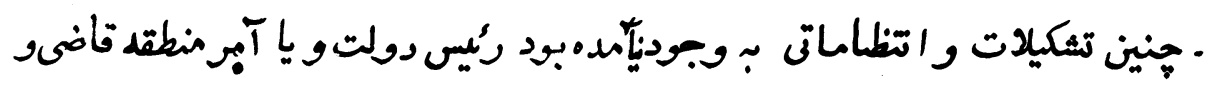

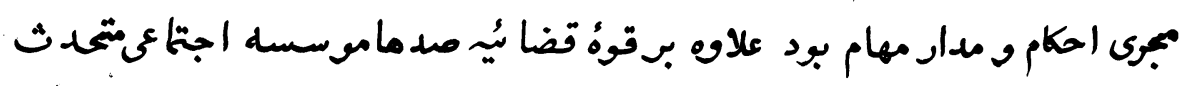

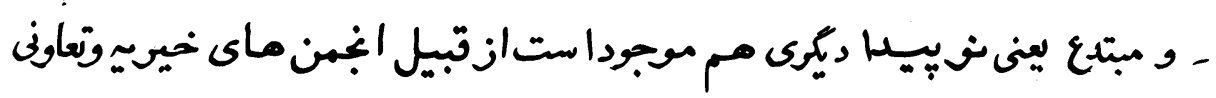

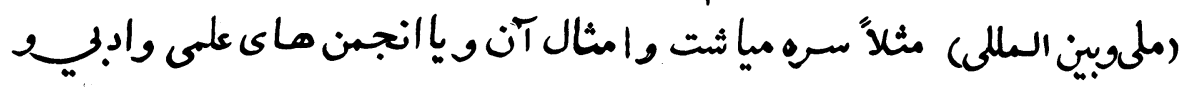

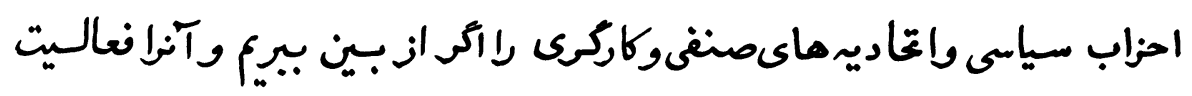

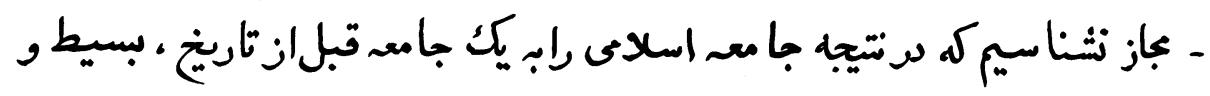

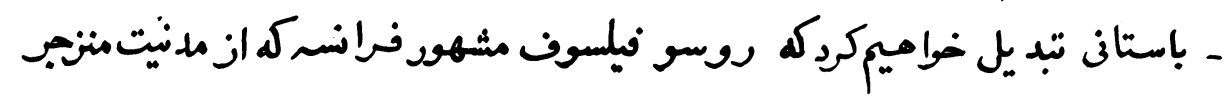

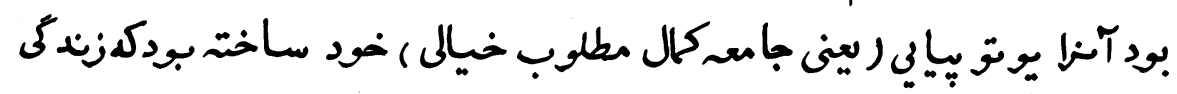

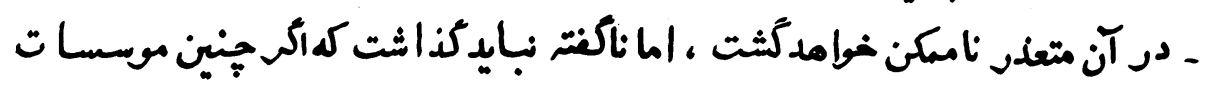

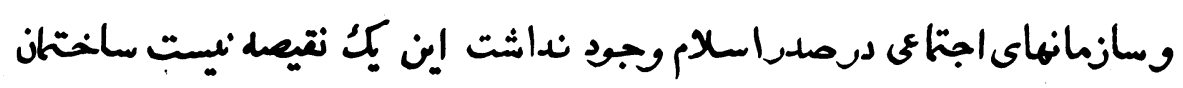

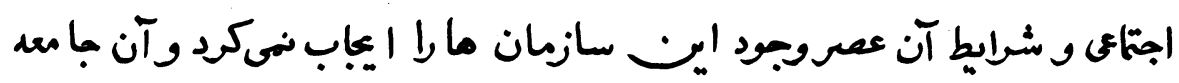

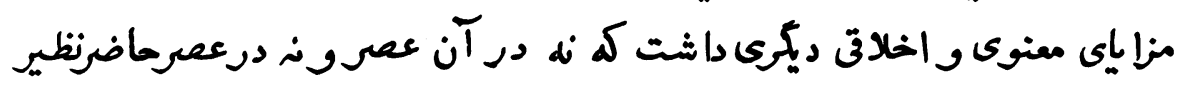

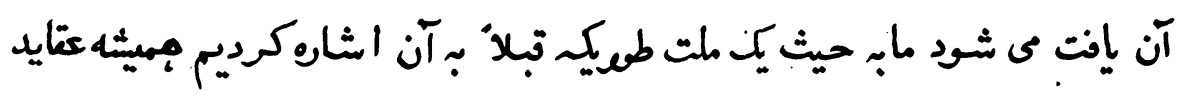

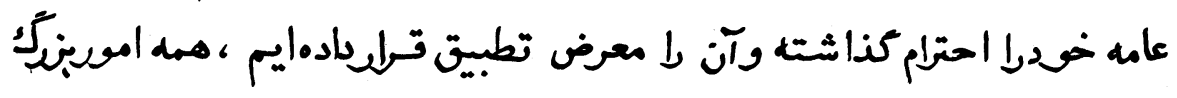

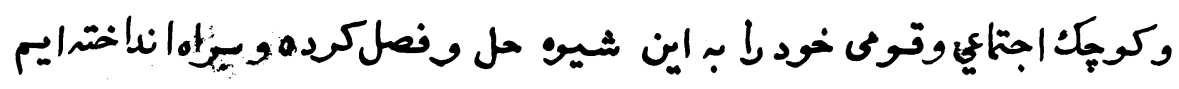

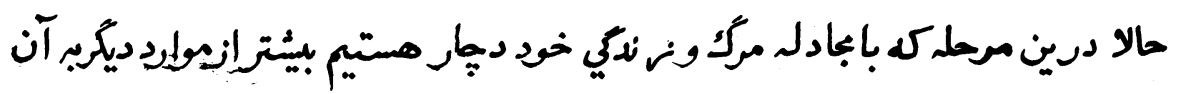



ro

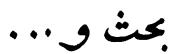

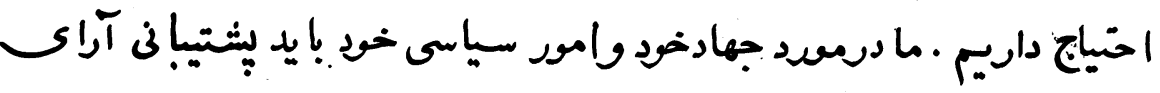

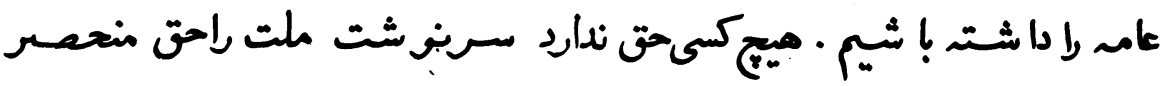

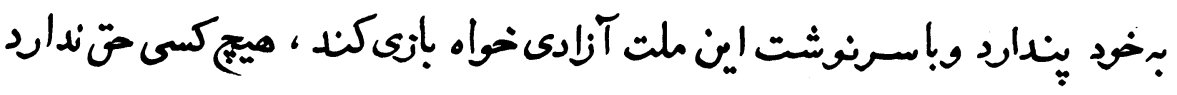

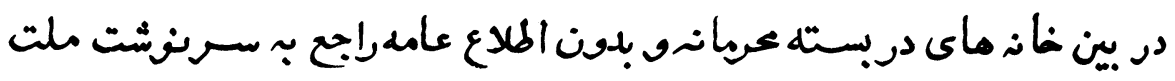

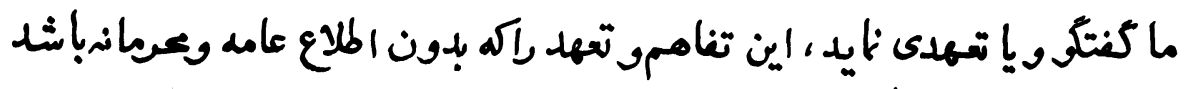

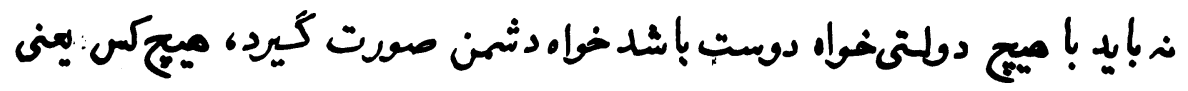

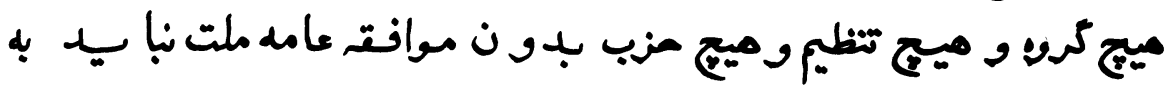

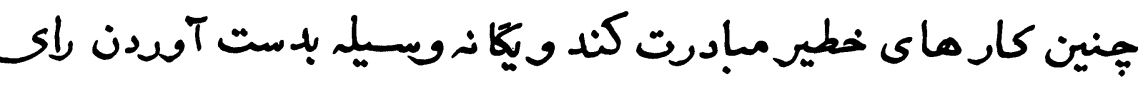

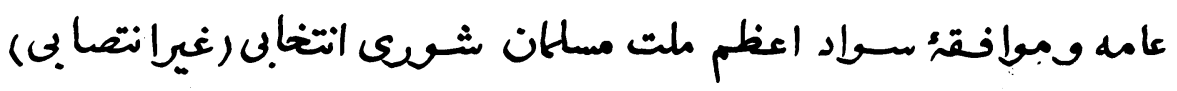
است ويس. 


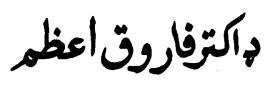

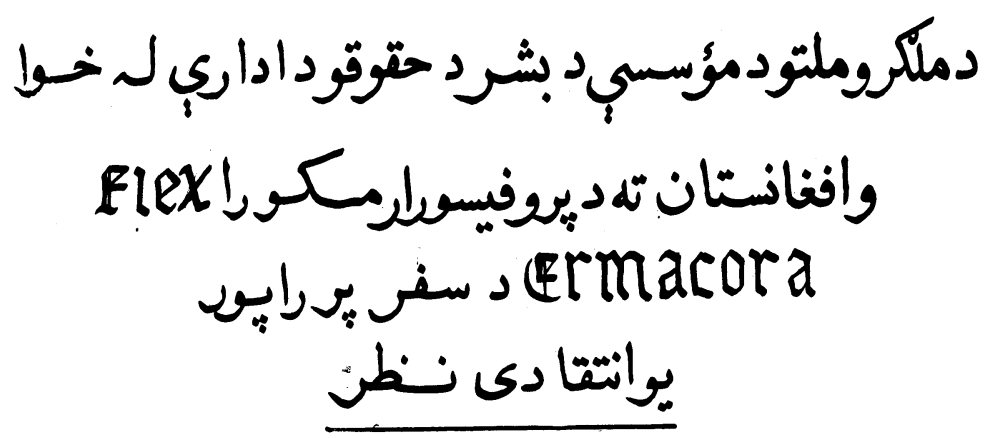

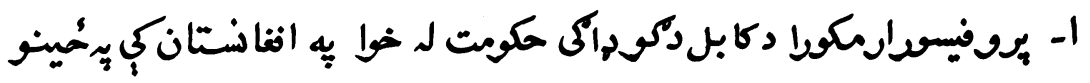

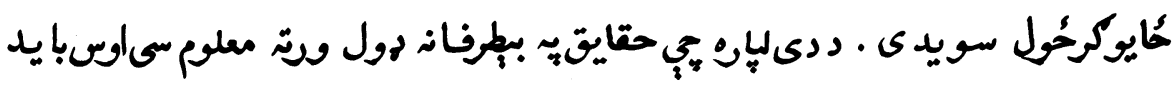
نومويى دباهدينولخ ورا افنا نستان ته ولارسى.

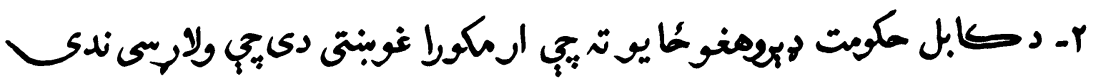

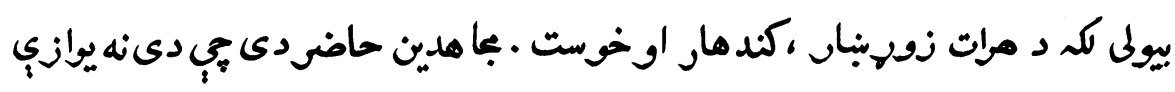

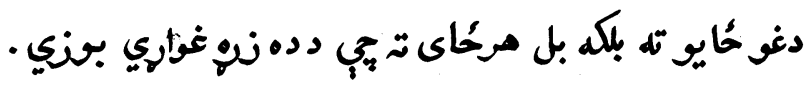

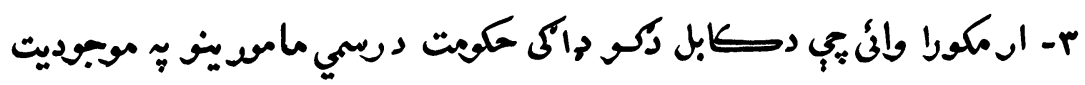

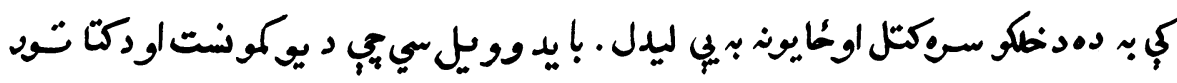

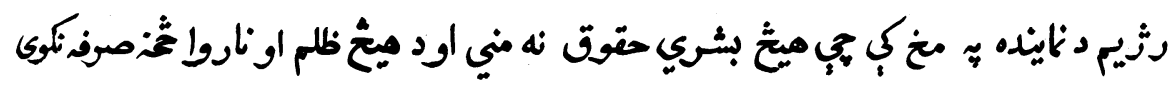




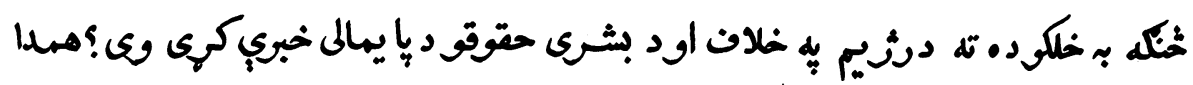

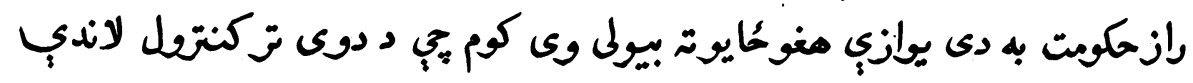

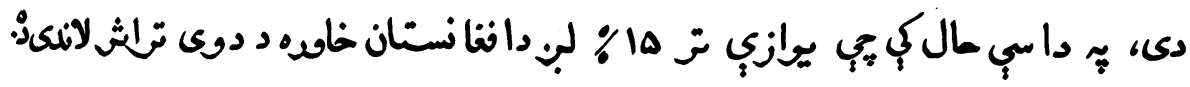

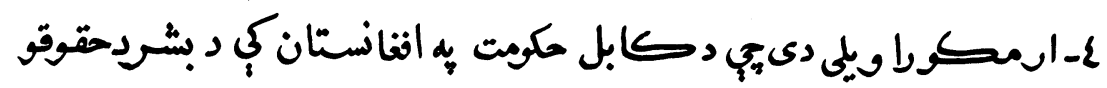

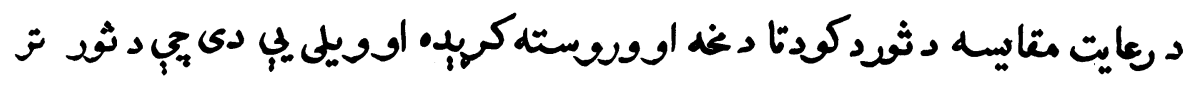

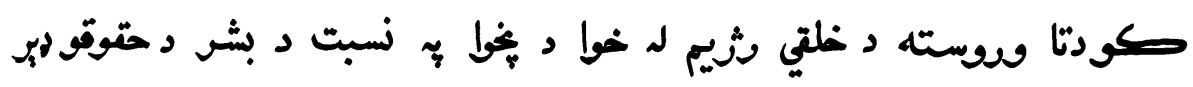

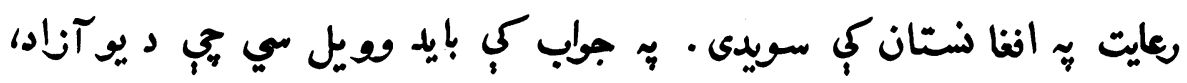

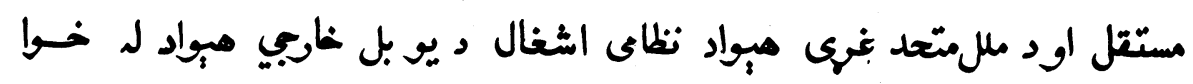

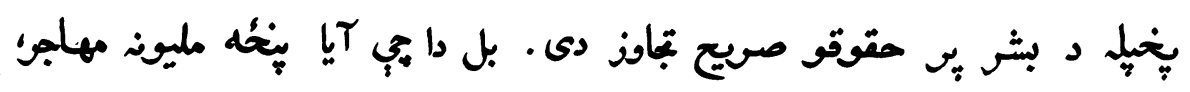

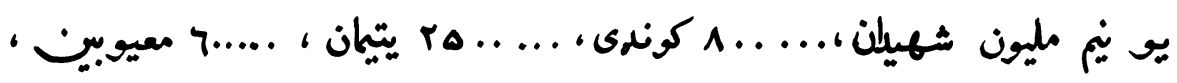

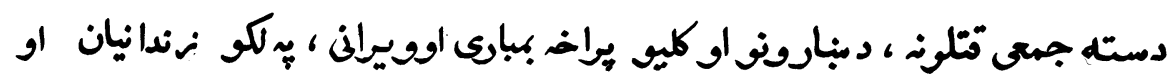

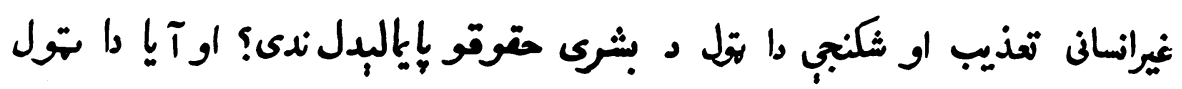
د ثور تزكودتا ويوستل سوبلى اوكم د غخ ؛ البته وبوسته .

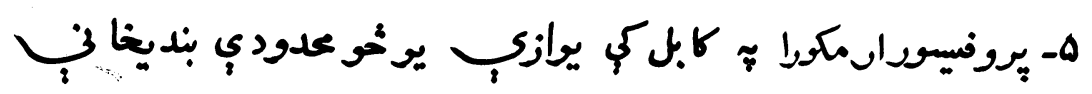

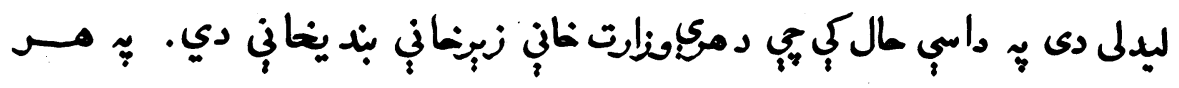

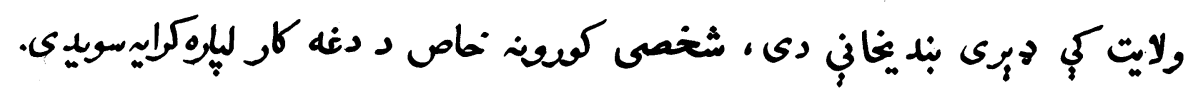

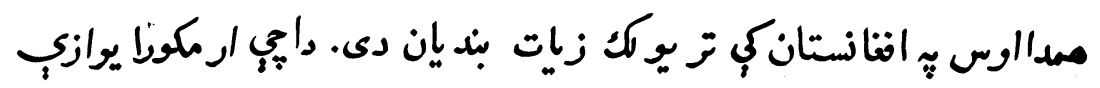

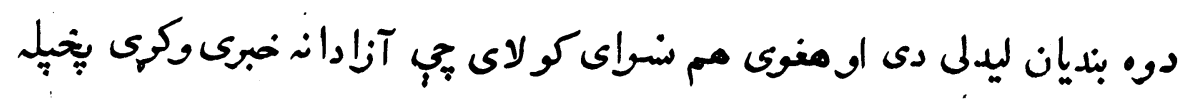

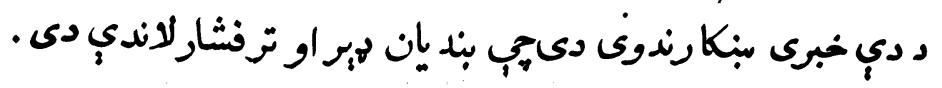




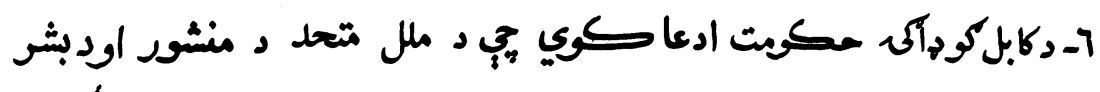

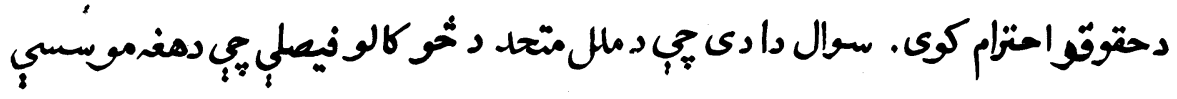

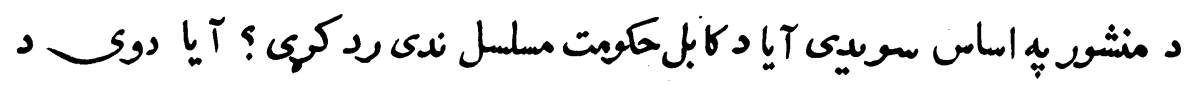
بشرد حقرقو د نهيوالو تولن لكه ستاكهالم ، ياريس او تقدينوفيصلي ندى ردكي.

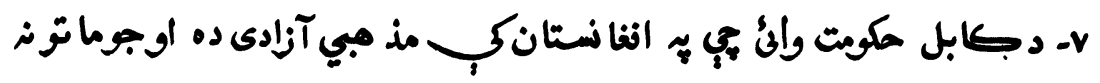

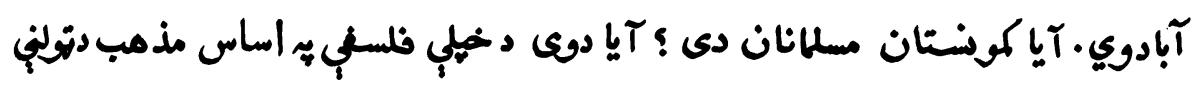

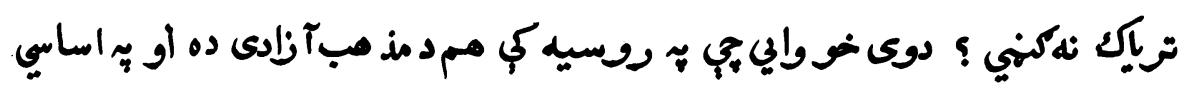

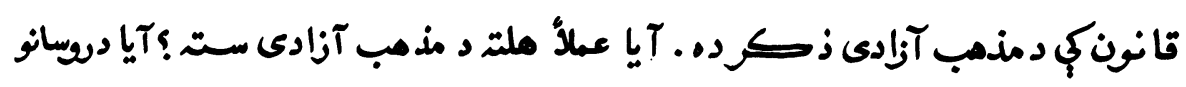

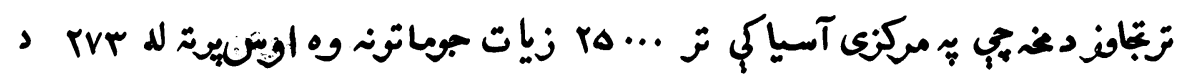

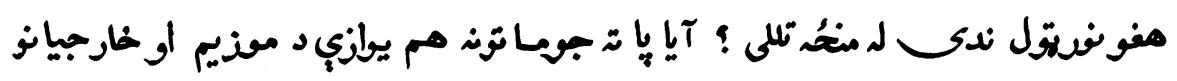

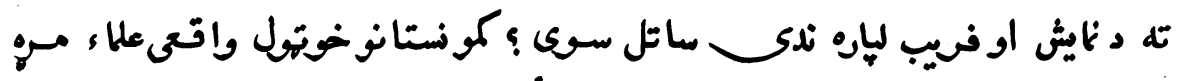

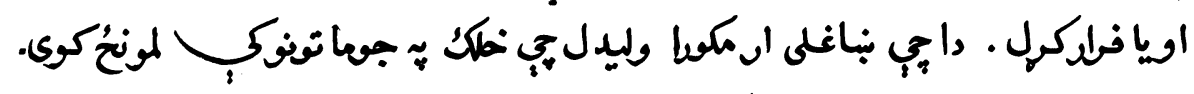

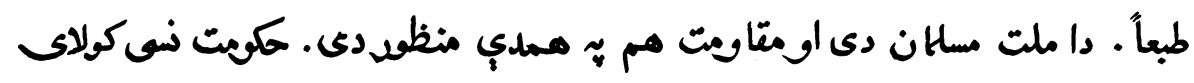

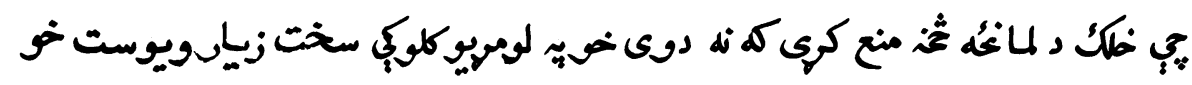

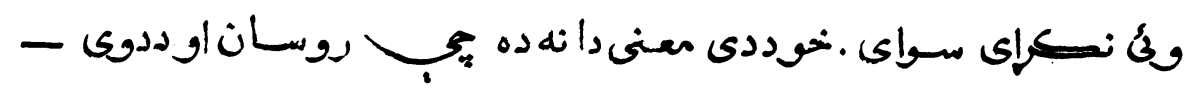

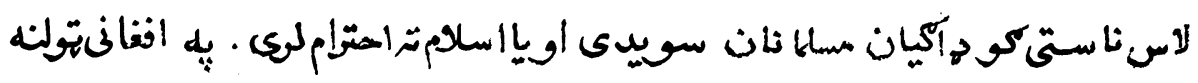

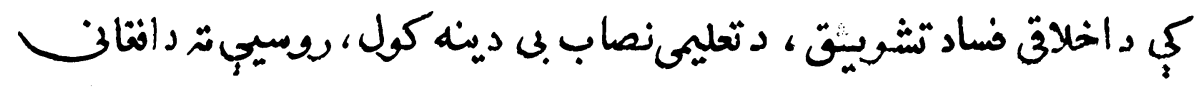

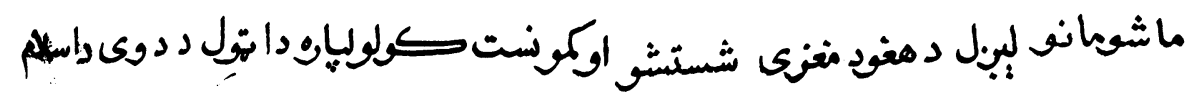
ضد اعمالو بنكارندويى دى . منئ. 
rq

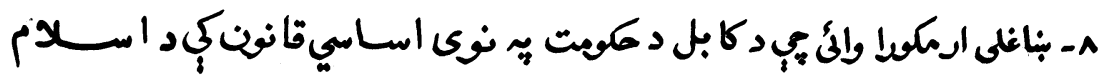

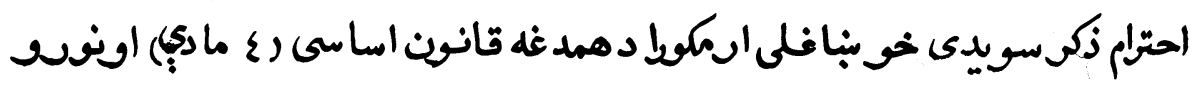

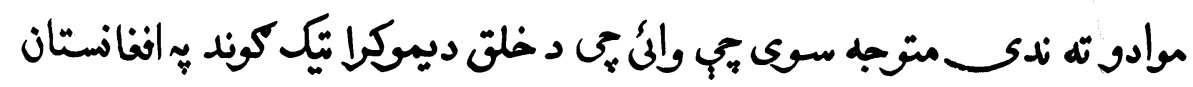

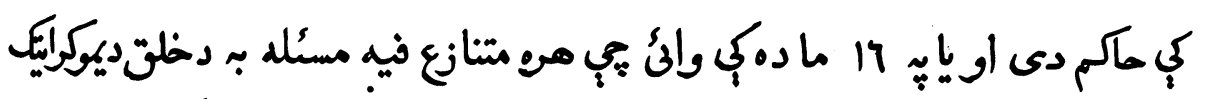

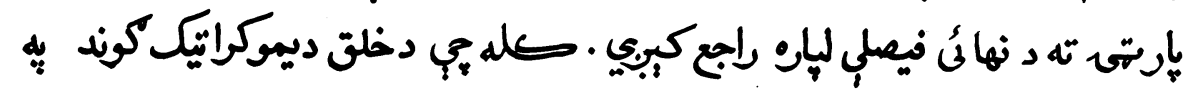
افنانستانكي واتعى حاكم اود فيصلونهائى مرجع وي بيانو اسلام ته احتّاميهنى

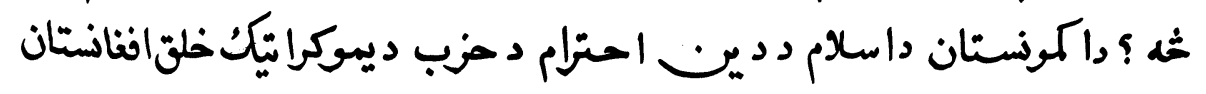

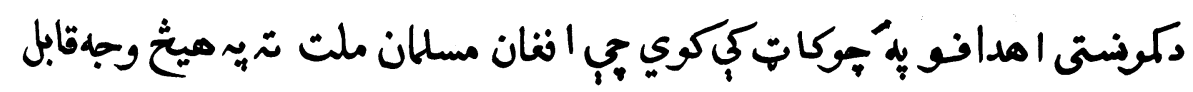

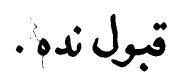

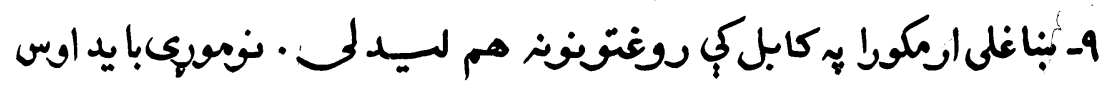

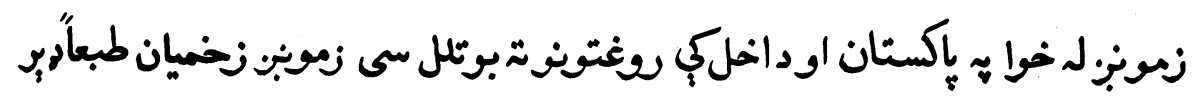

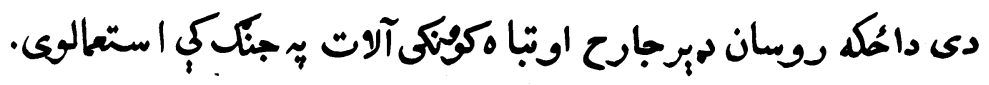

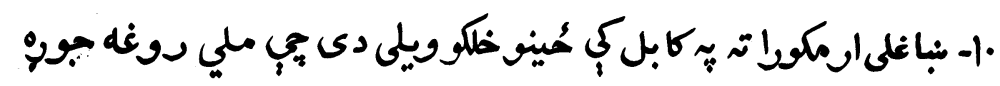

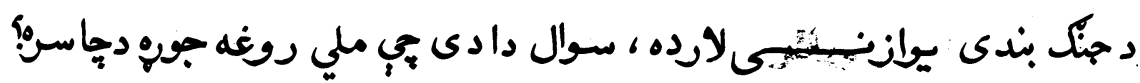

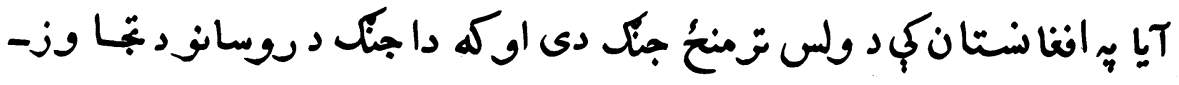

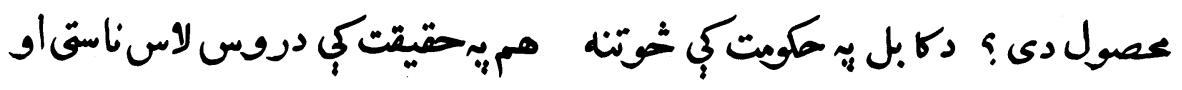

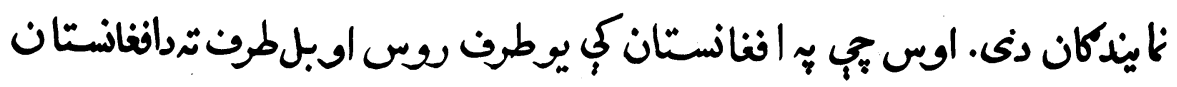

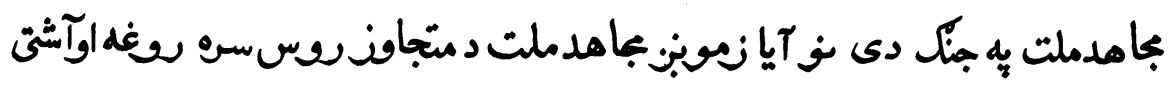

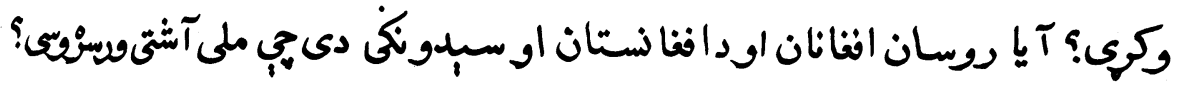




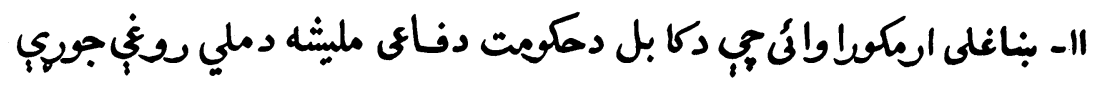

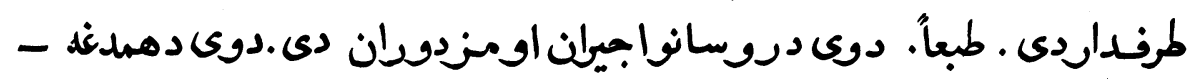

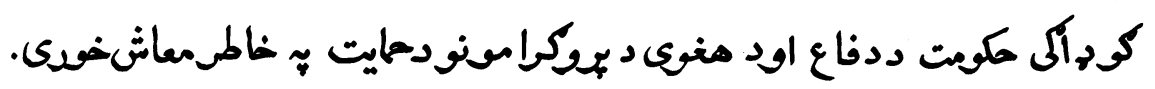

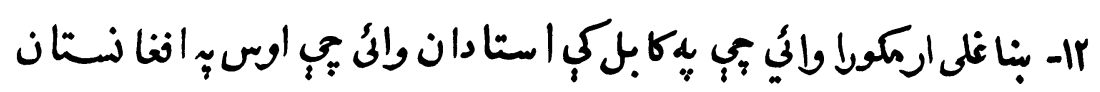

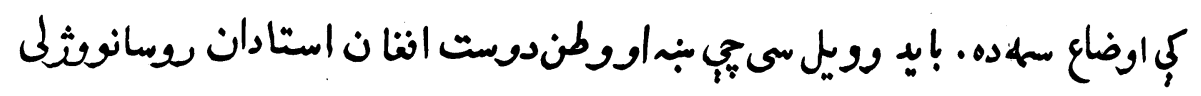

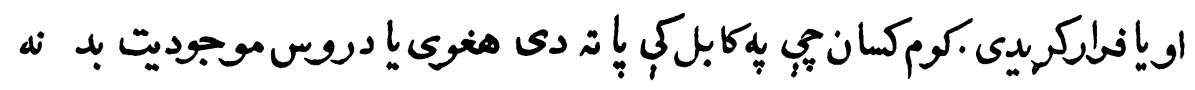
بولي او إل هاريخخه حقيقت نسيويلائ.

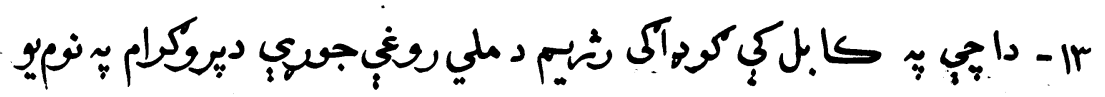

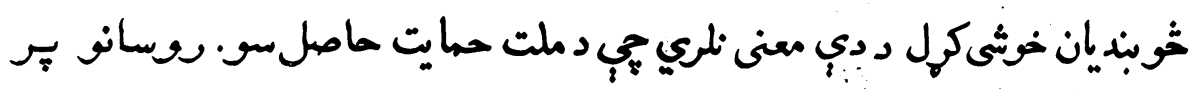

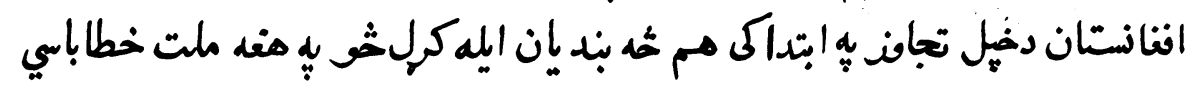

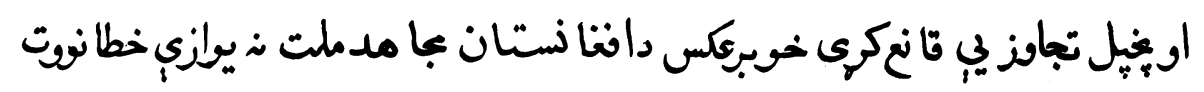

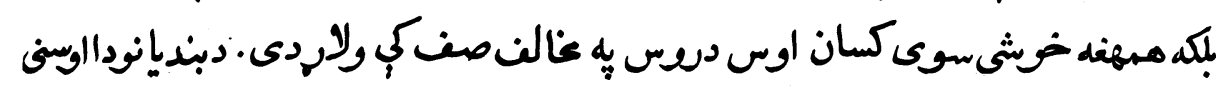

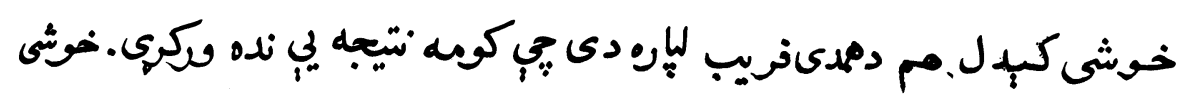

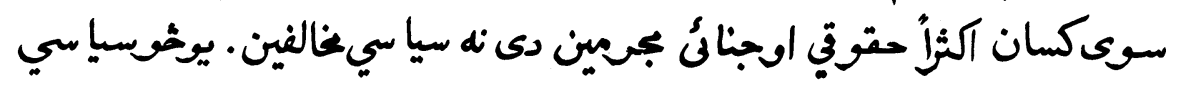

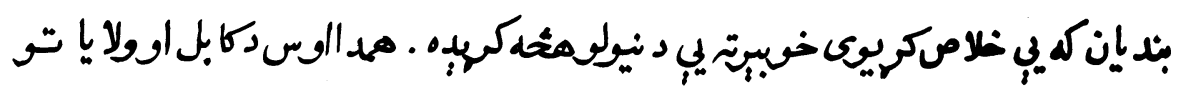

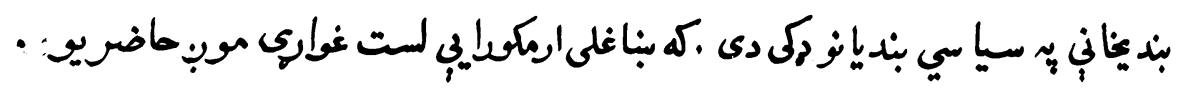

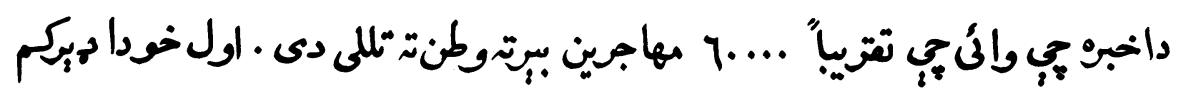

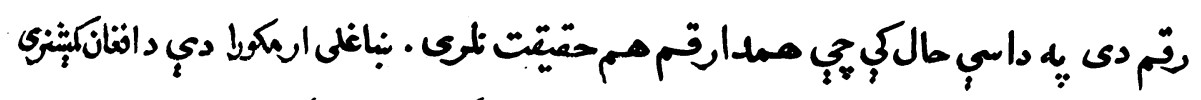

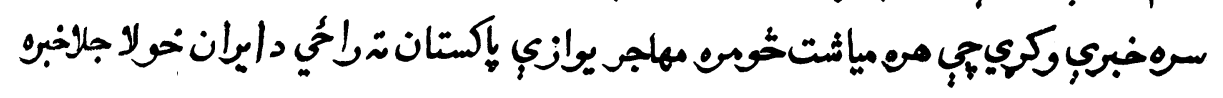




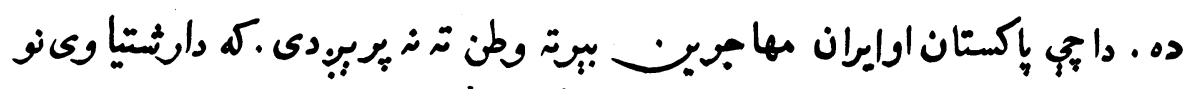

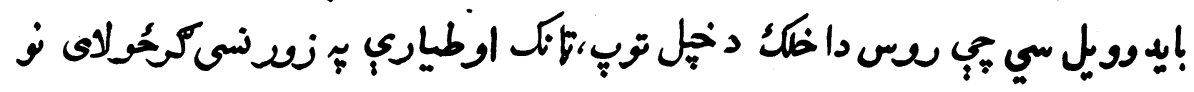

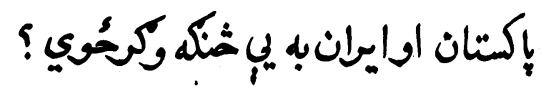

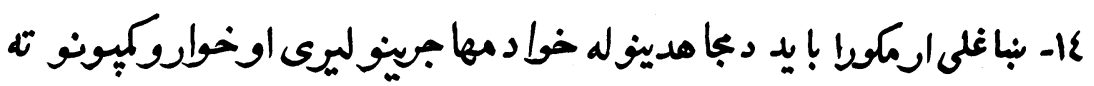

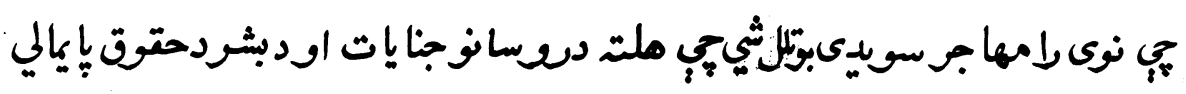
بخهله وويني. 
كوكياني

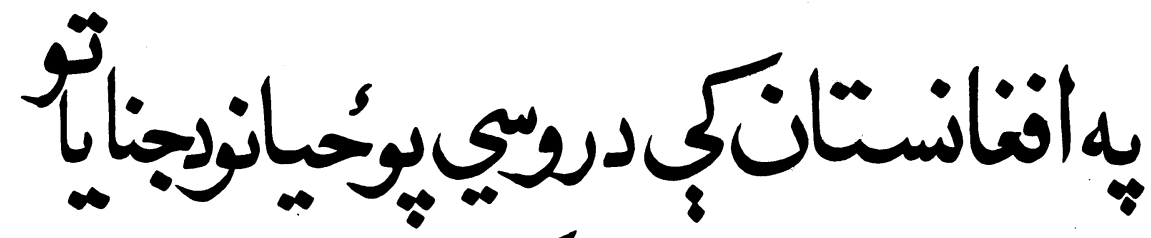

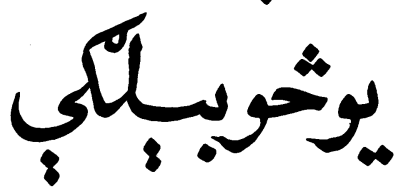

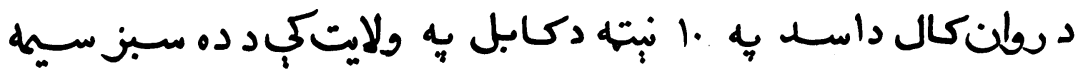

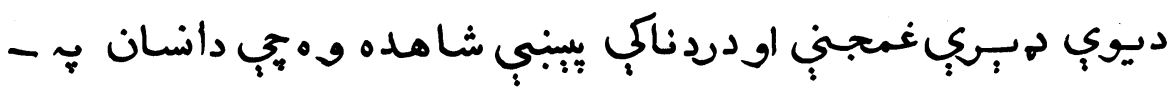

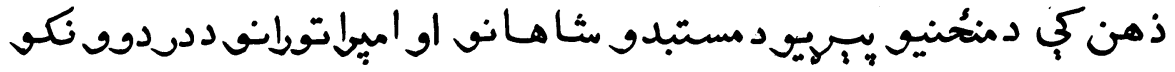

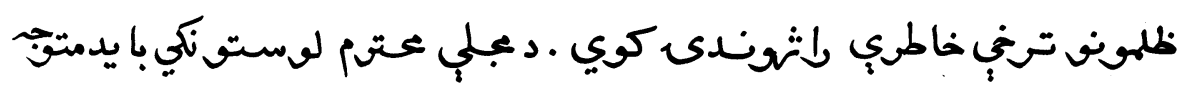

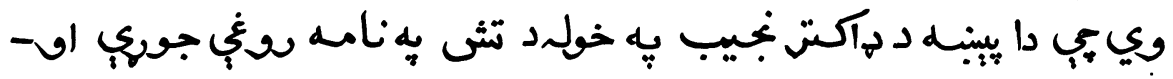

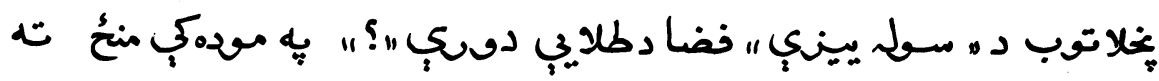

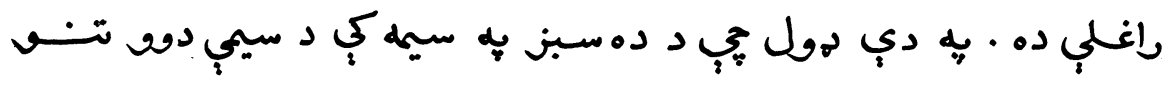

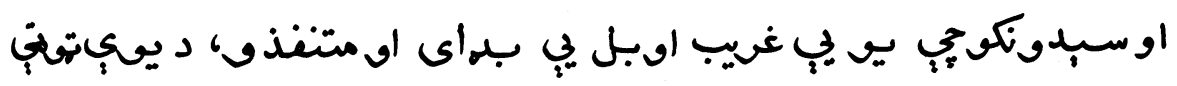

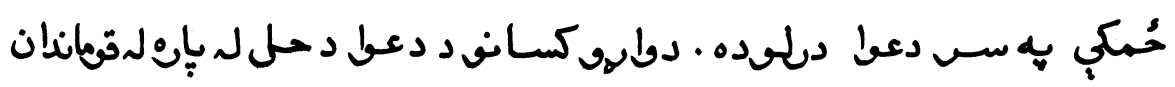

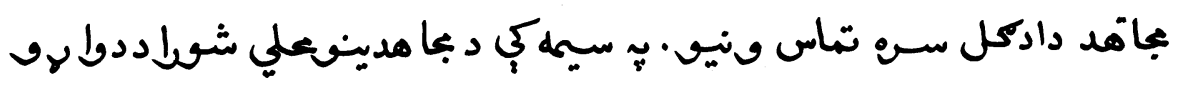


يم افنانتسانكک?

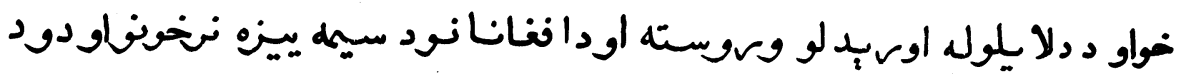

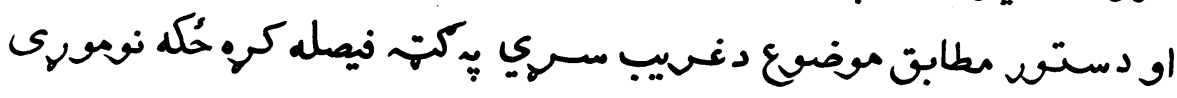

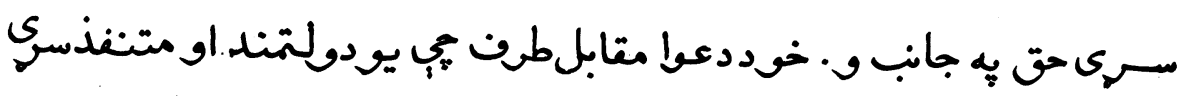

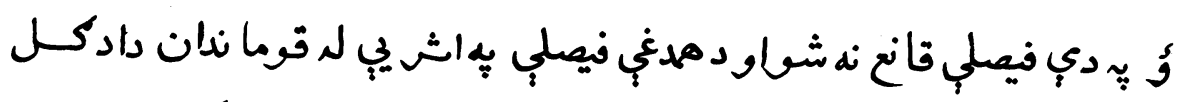

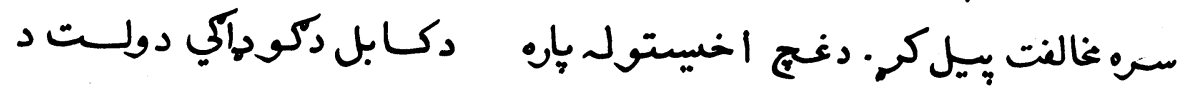

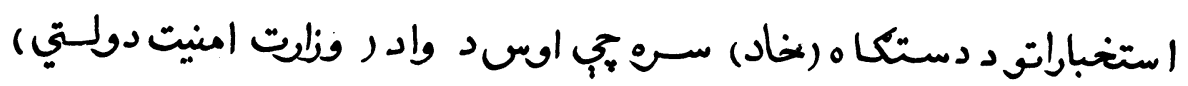

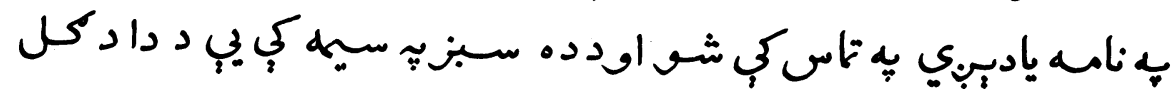

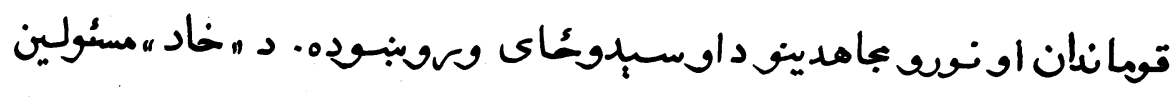

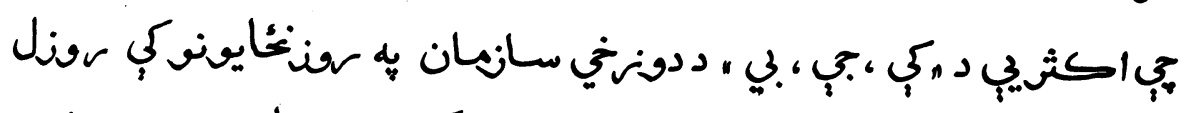

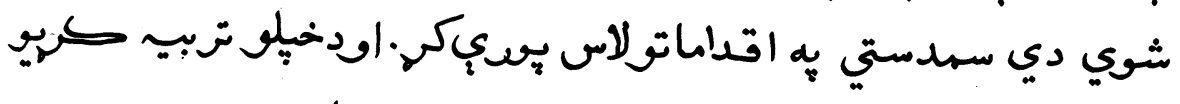

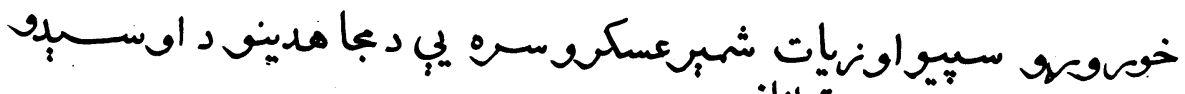

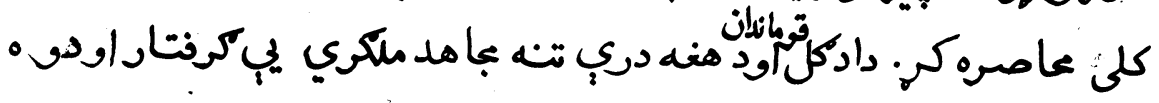

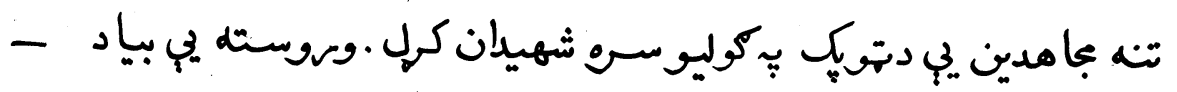

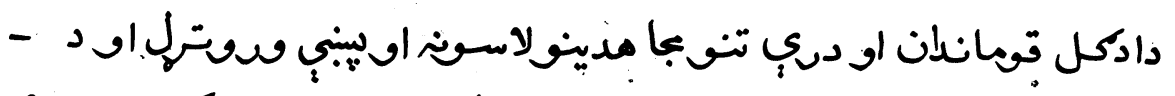

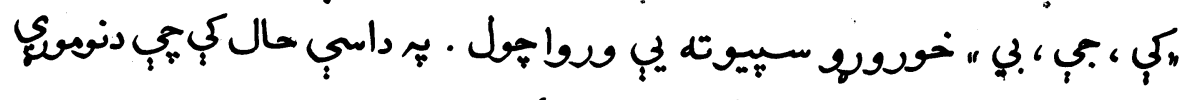

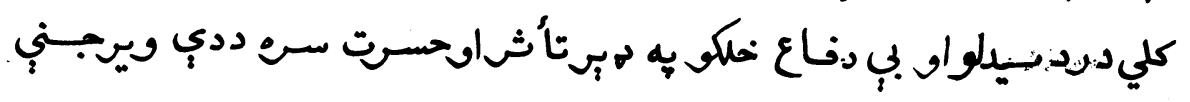

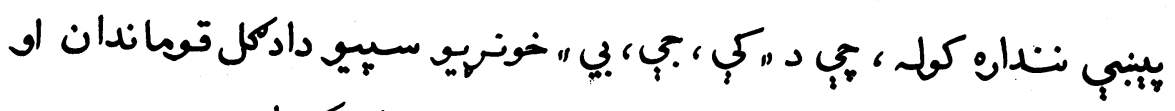

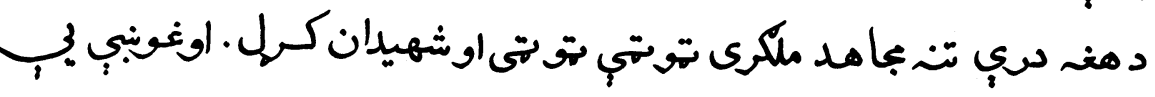




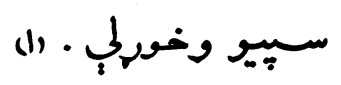

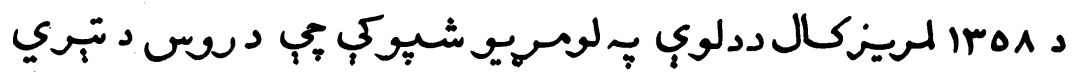

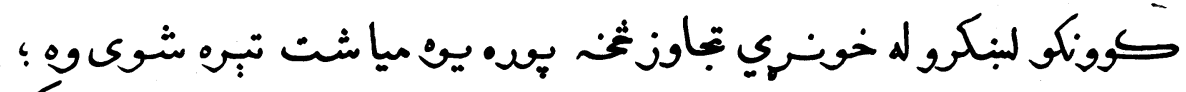

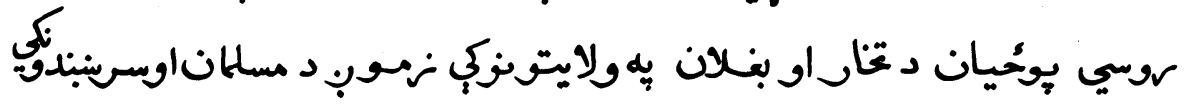

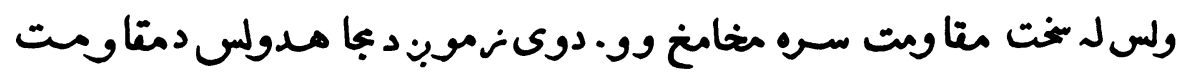

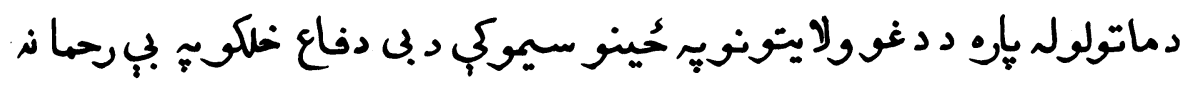

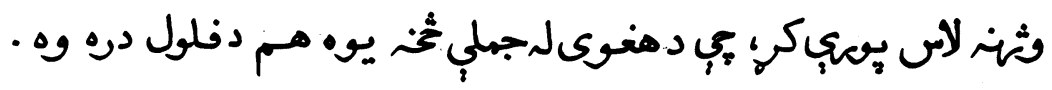

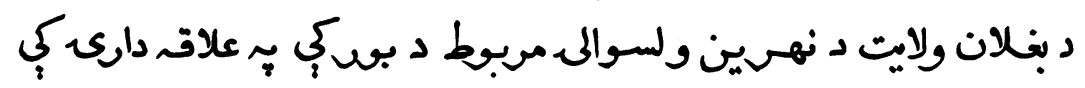

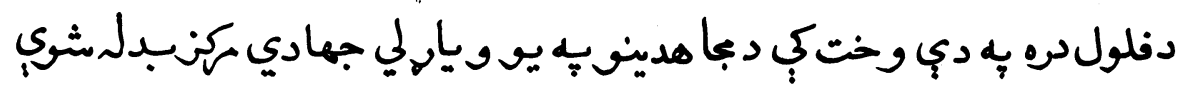

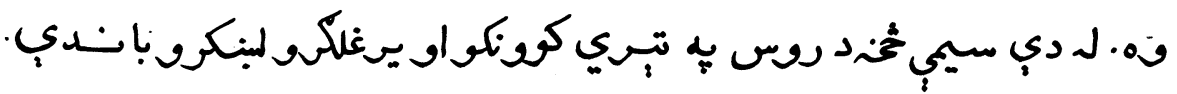

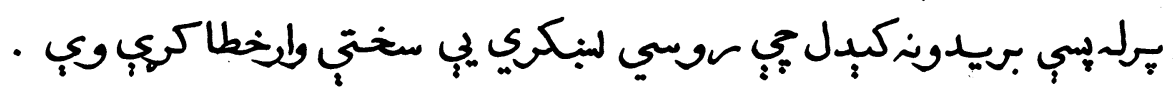

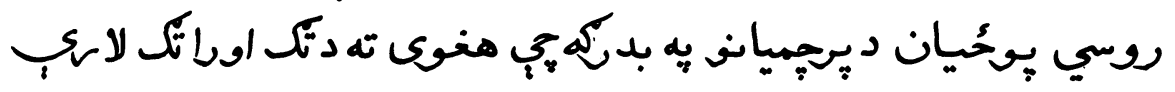

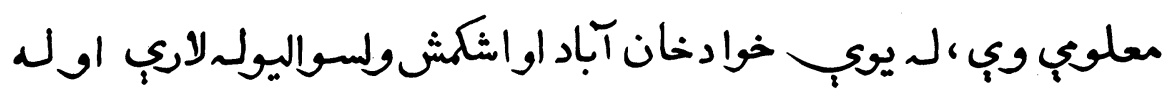

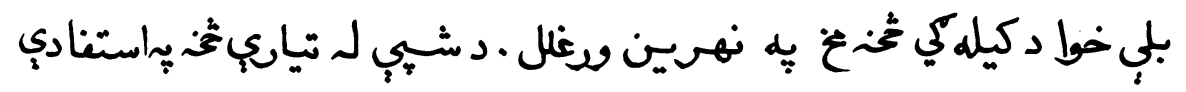

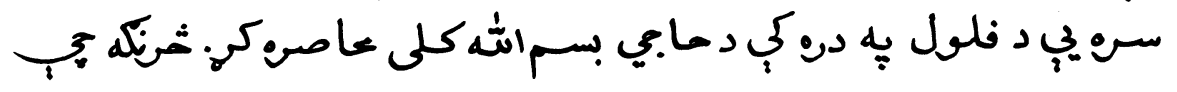

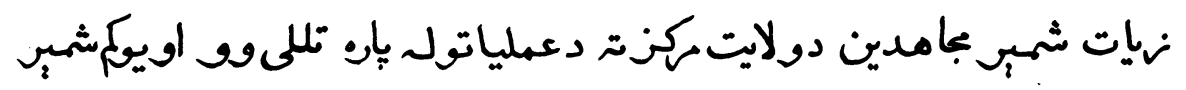

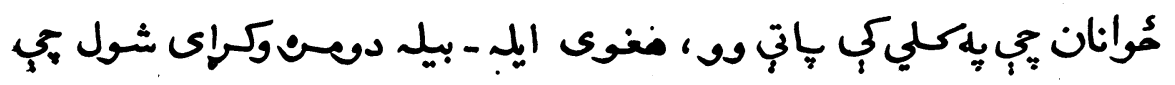

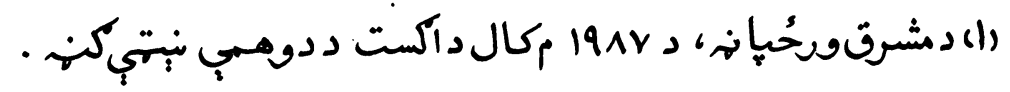




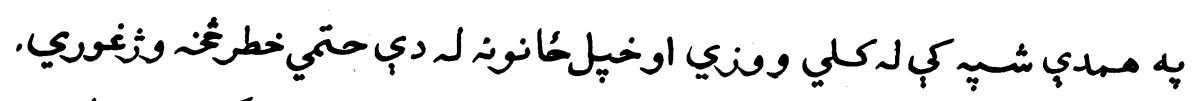

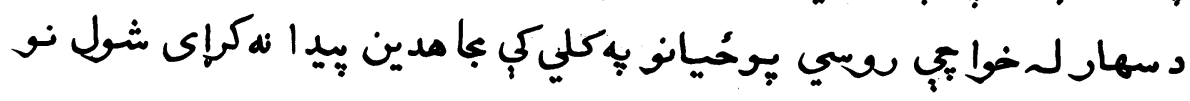

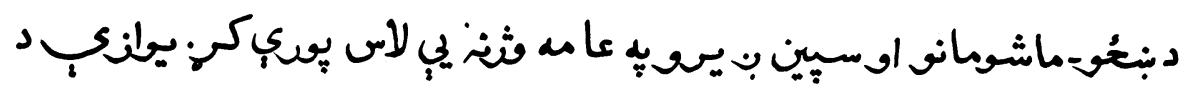

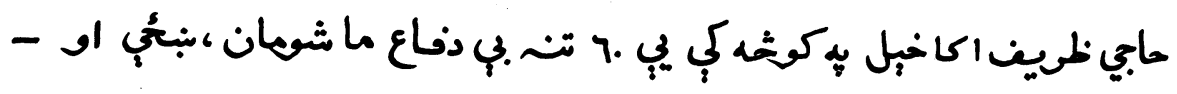

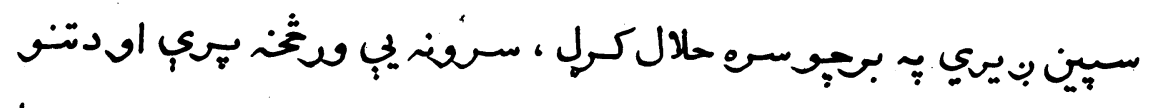

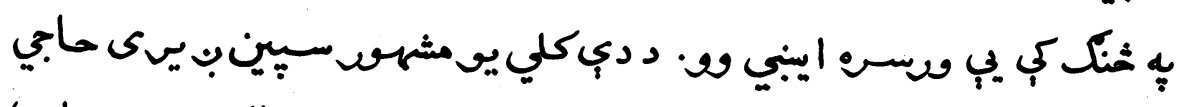

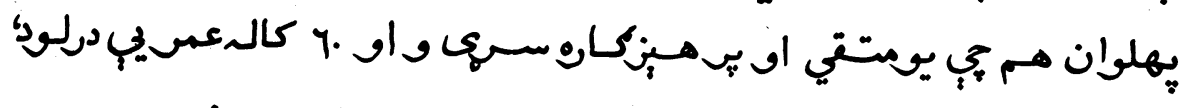

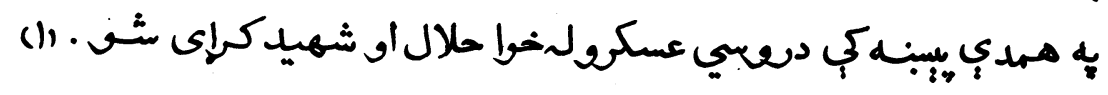

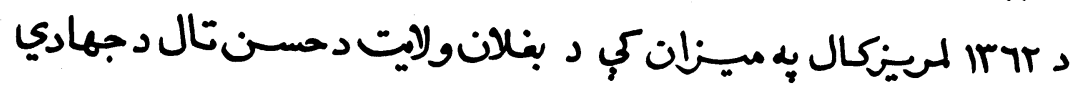

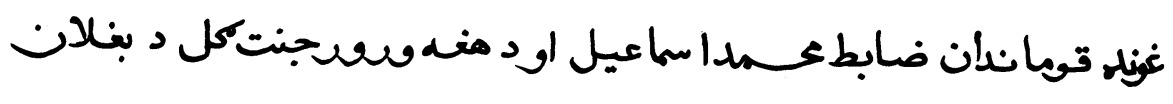

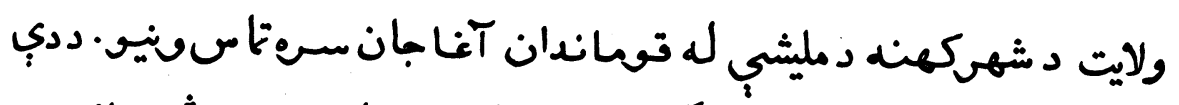

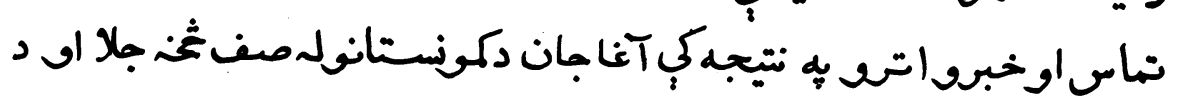

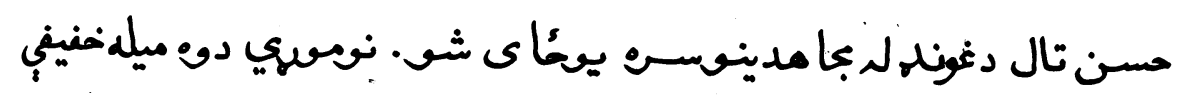

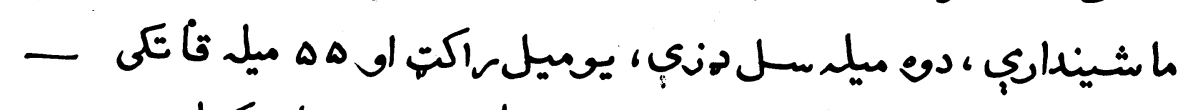

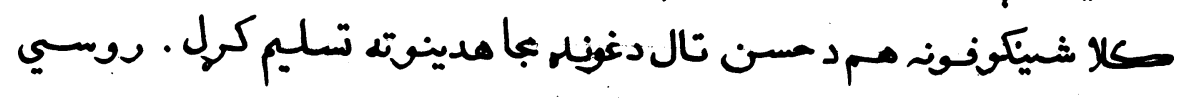

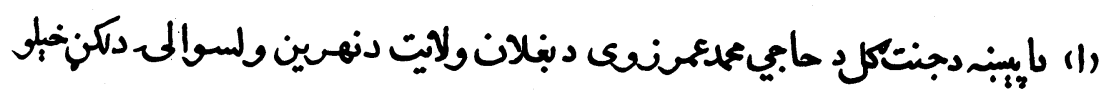
د توم اوسـبدونكي لـ خولي ليكل شـوي دهـ. 


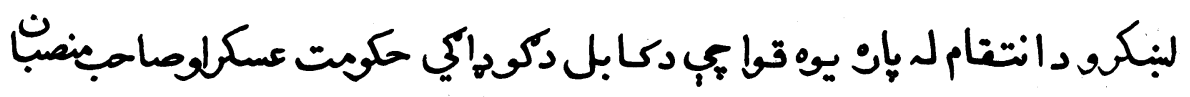

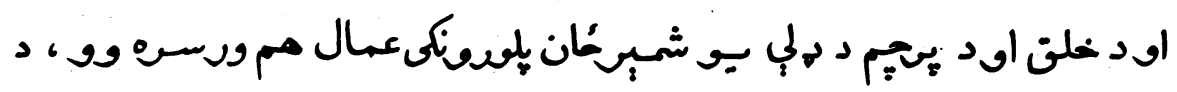

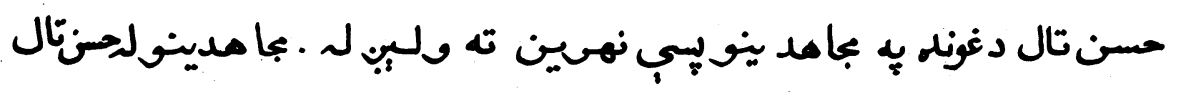

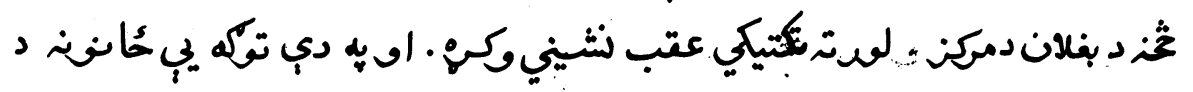

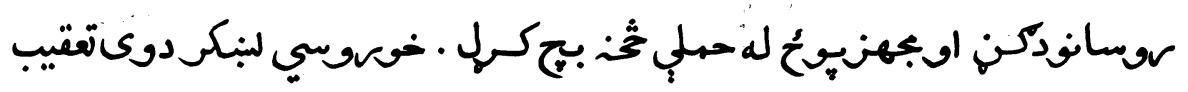

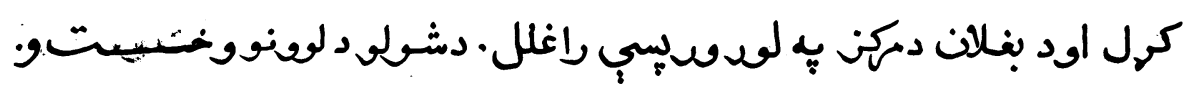

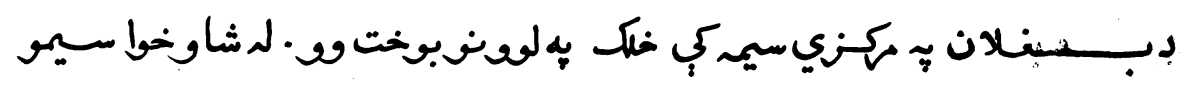

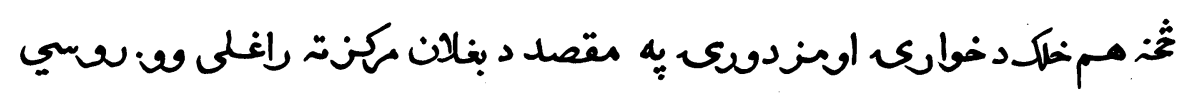

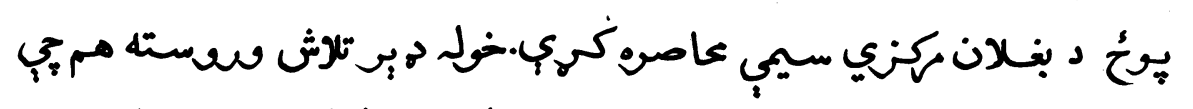

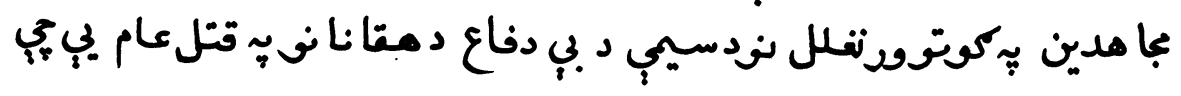

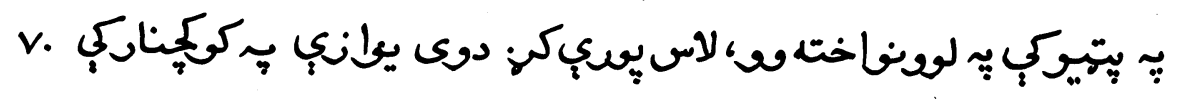

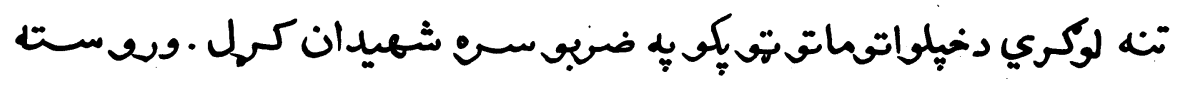

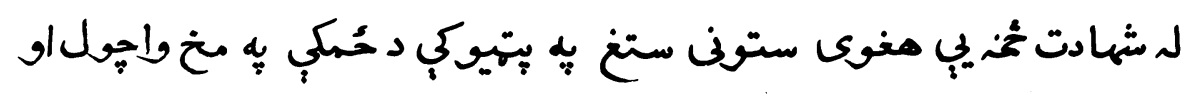

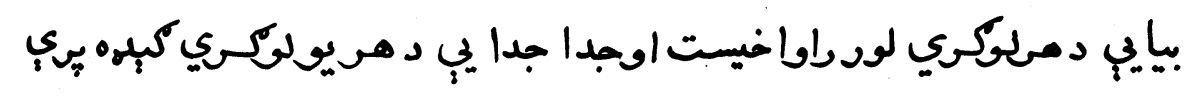

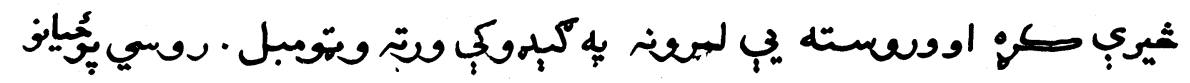

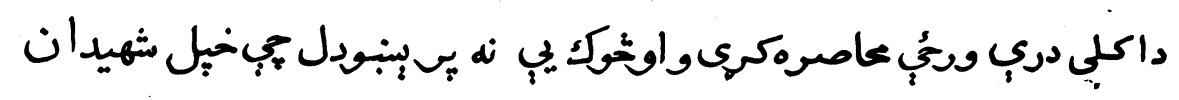

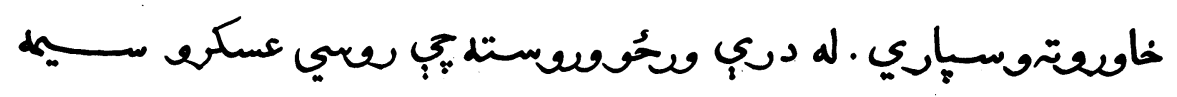

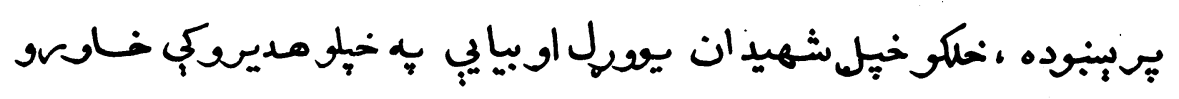




rr

$$
\text { (1) ته ومسيّارل }
$$

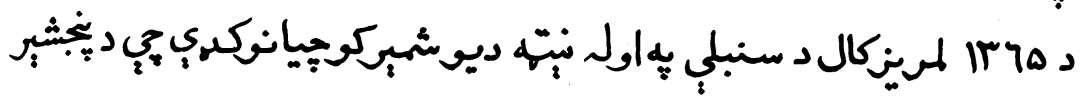

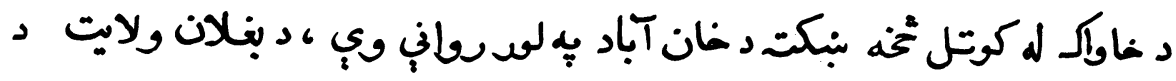

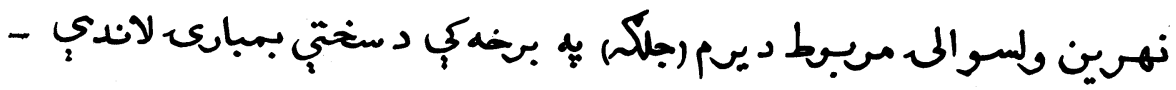

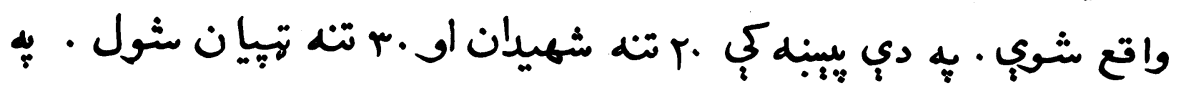

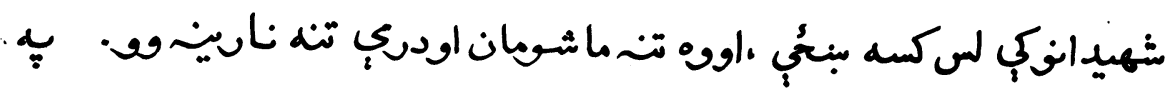

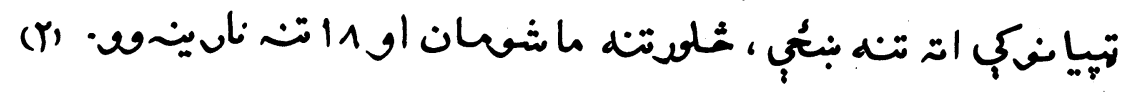

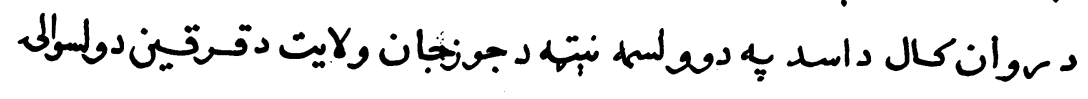

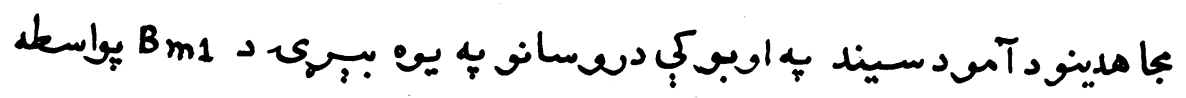

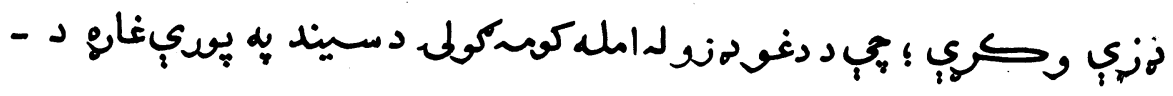

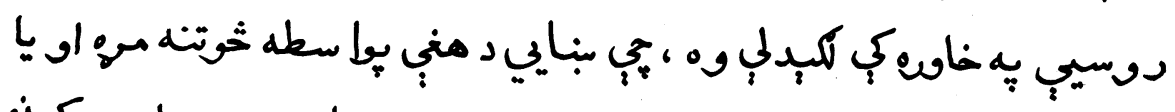

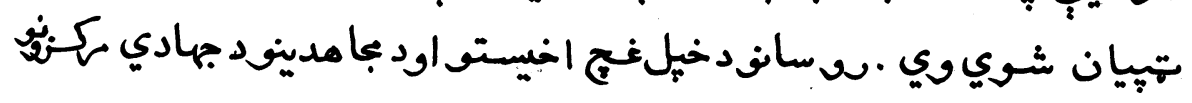

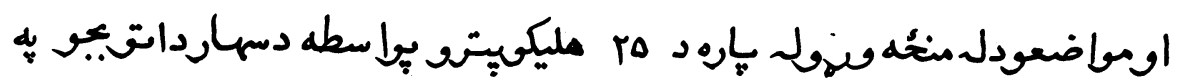

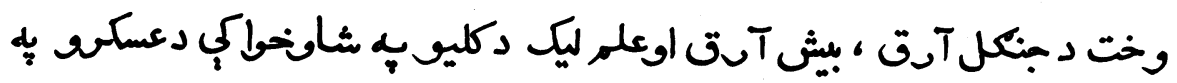

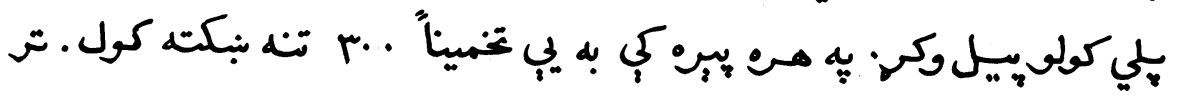

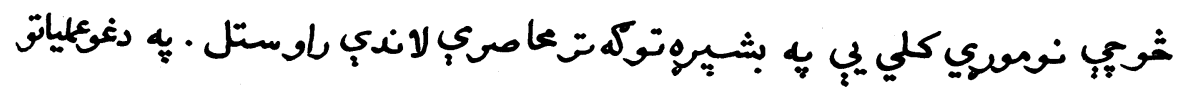

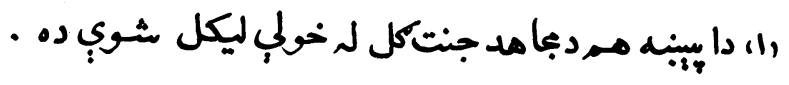
• (r) 


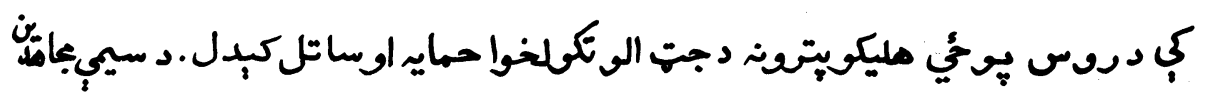

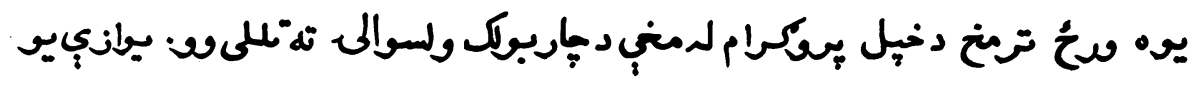

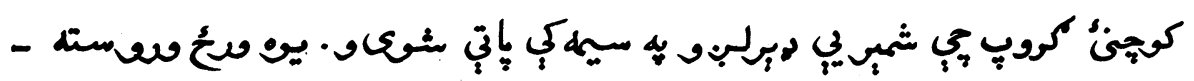

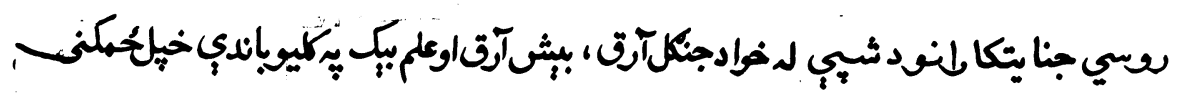

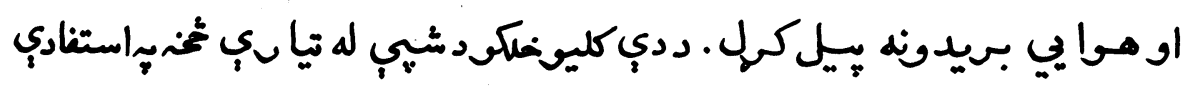

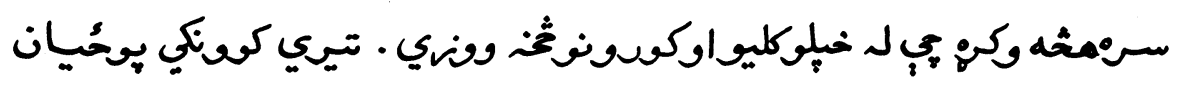

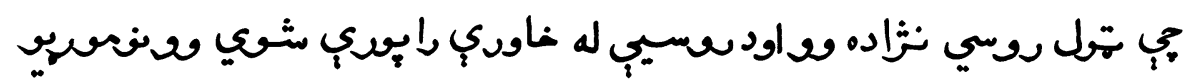

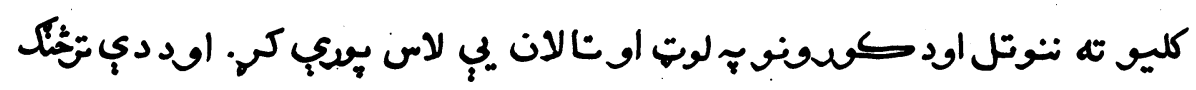

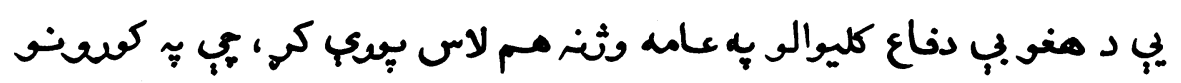

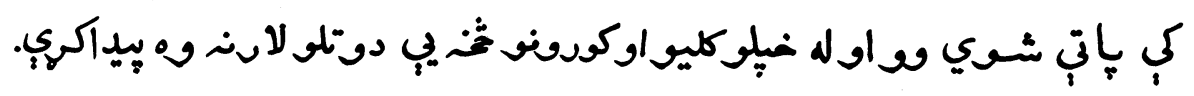

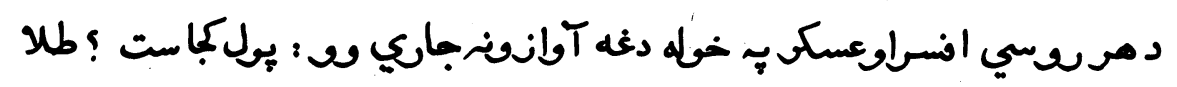

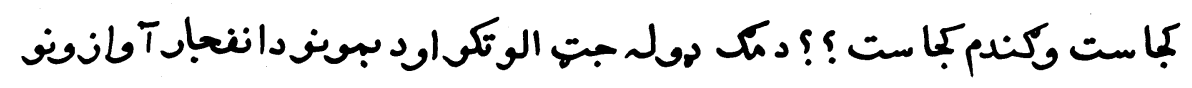

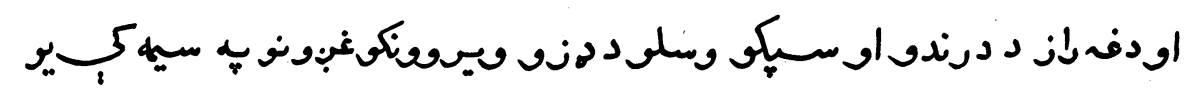

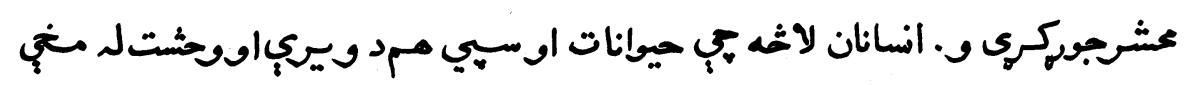

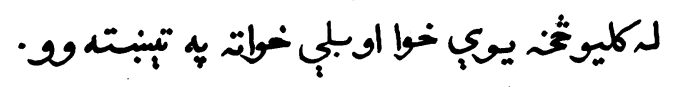

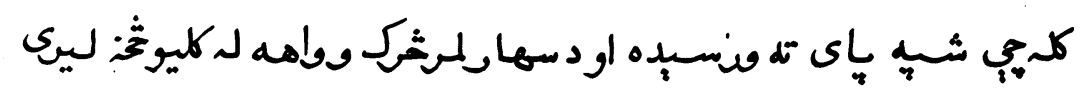

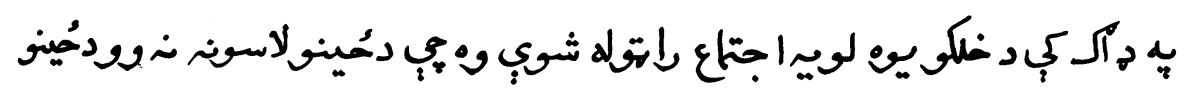

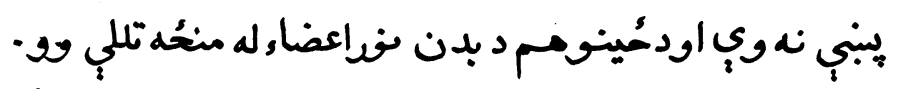

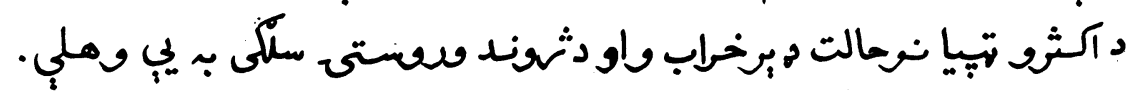


ra

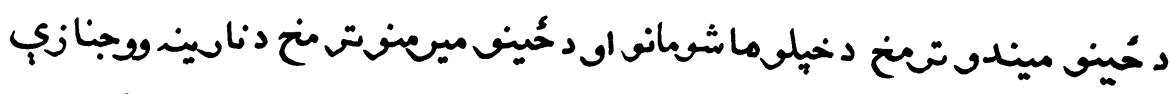

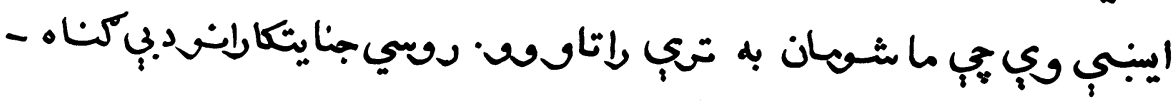

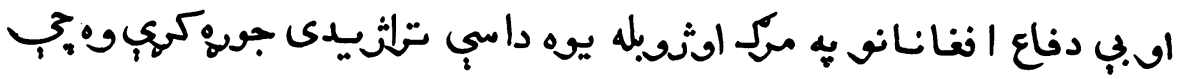

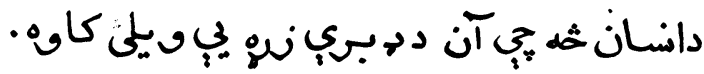

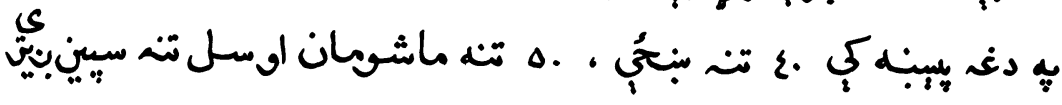

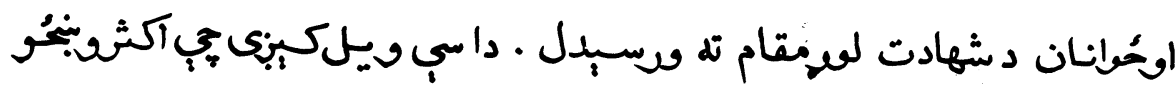

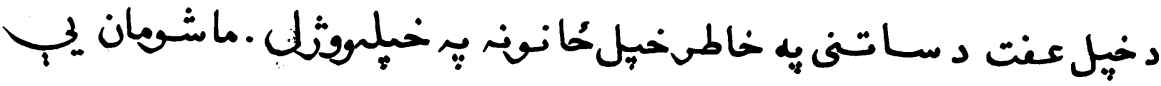

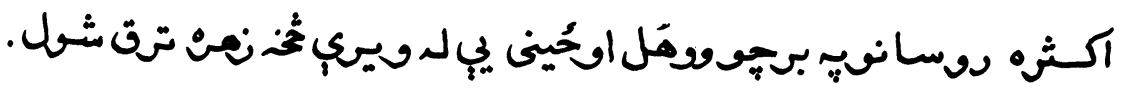

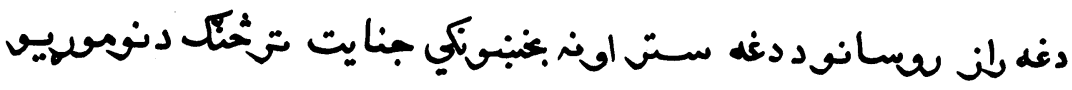

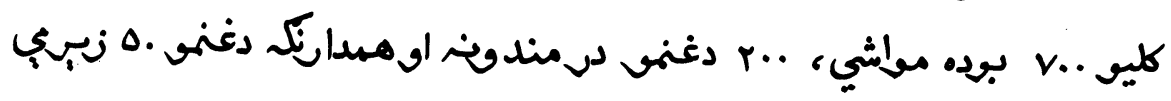

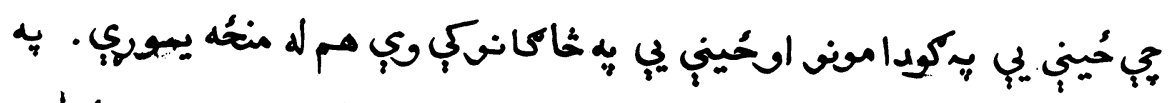

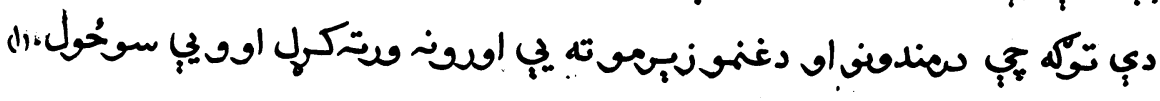

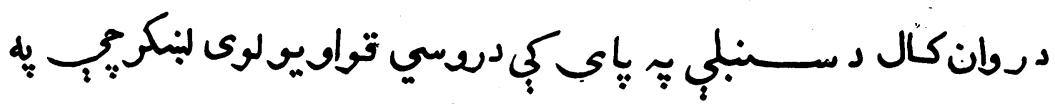

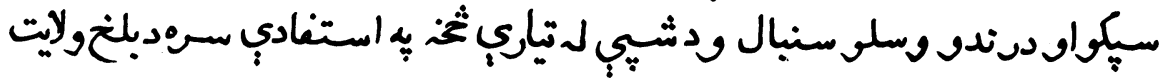

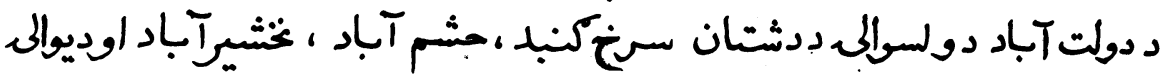

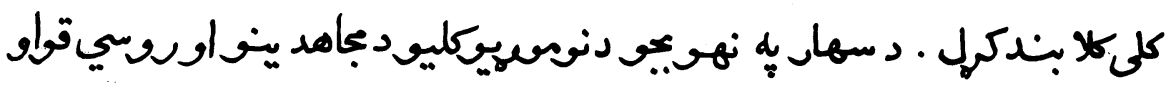

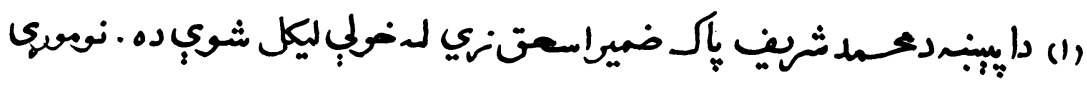
دعاذ ملى اسلامي دبلخ ولايتى آمردى. 


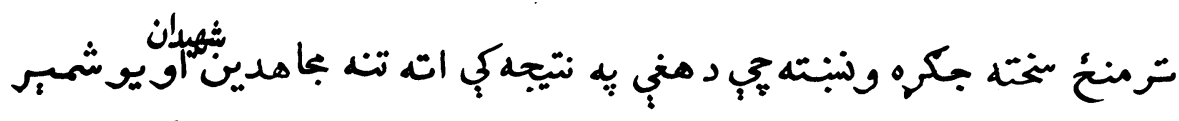

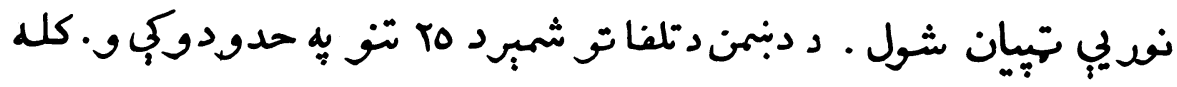

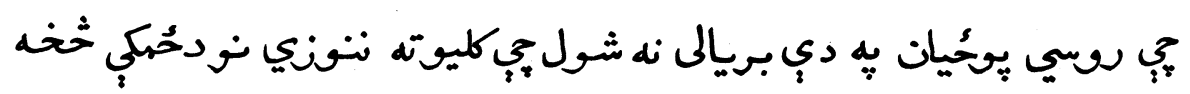

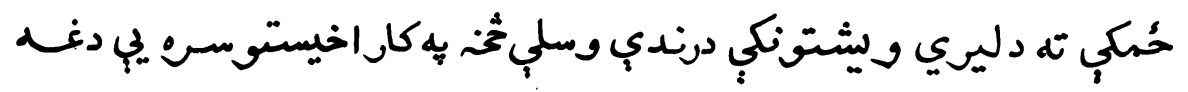

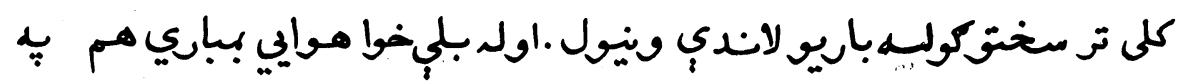

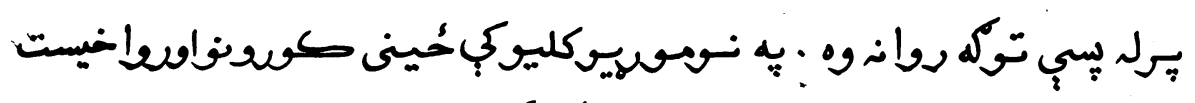

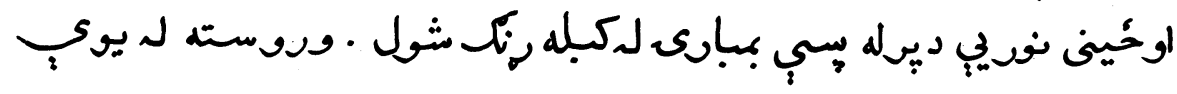

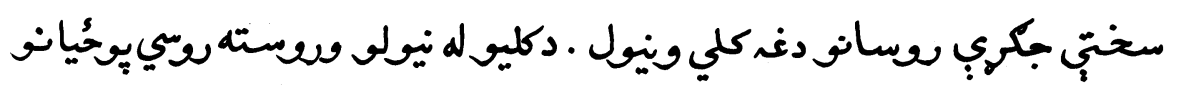

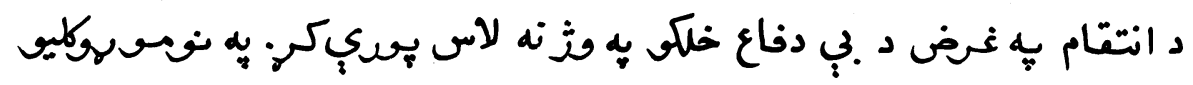

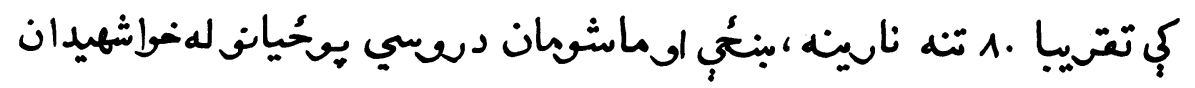

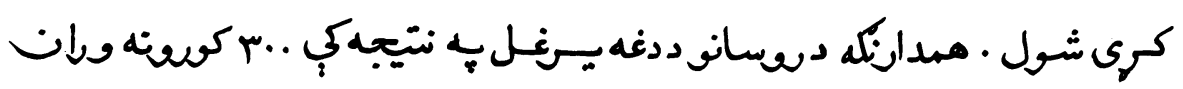

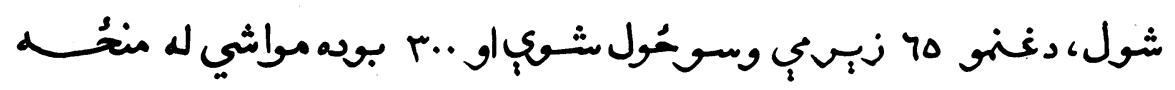

$$
\text { (1) . ولارل }
$$

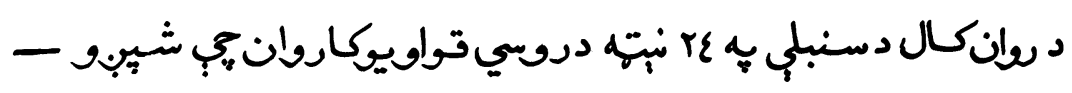

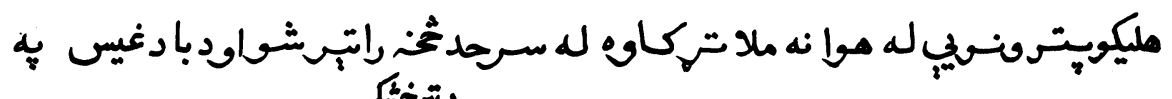

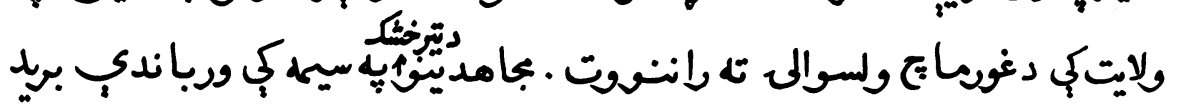

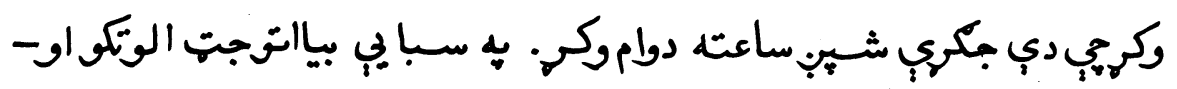

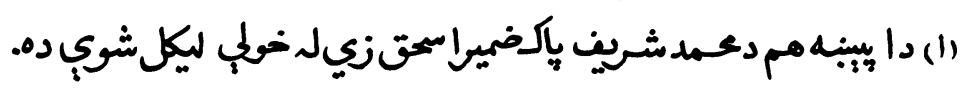




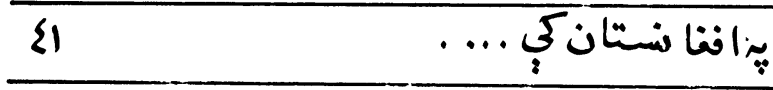

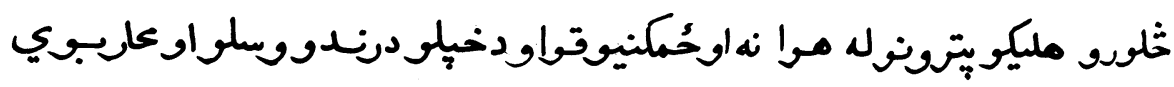

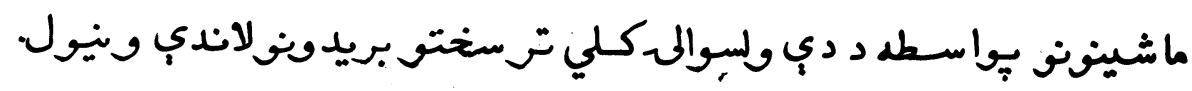

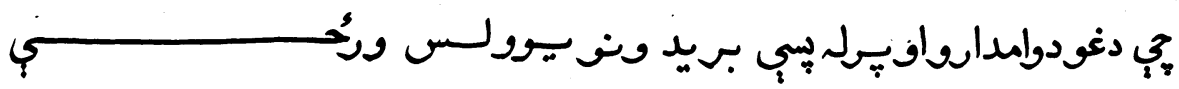

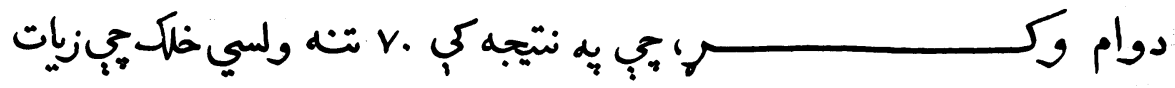

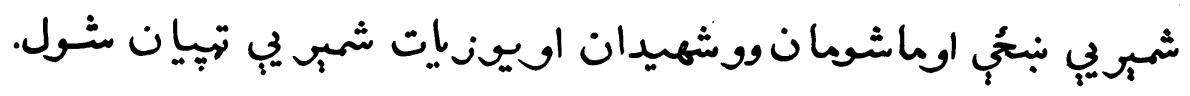

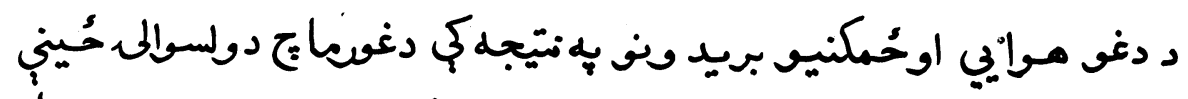

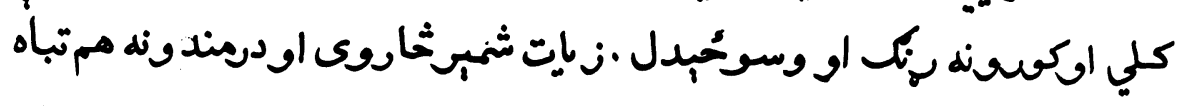

$$
\text { شول . (1). }
$$

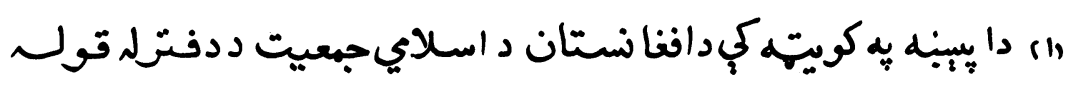
ليكل شوين ده. 

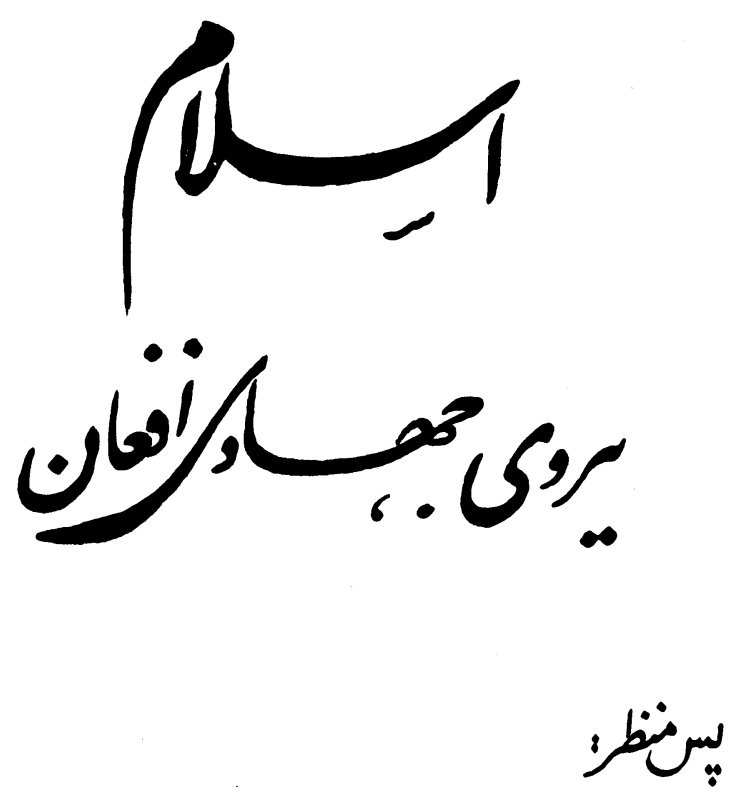

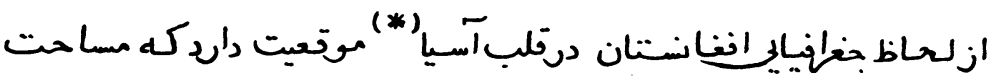

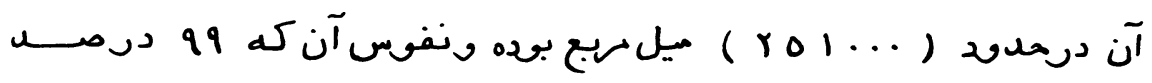

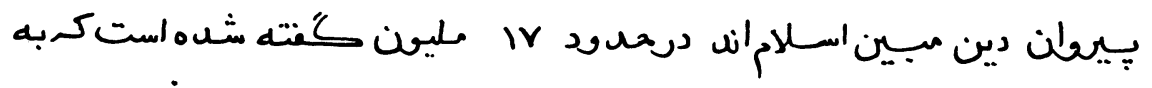

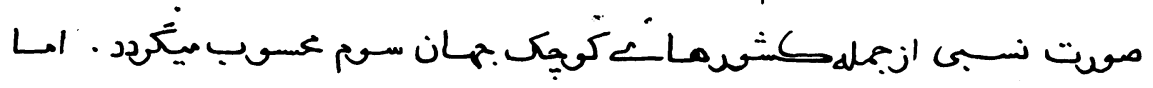

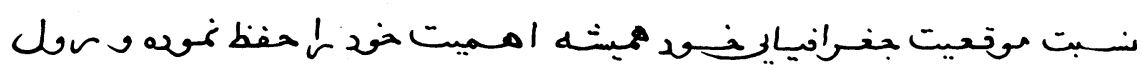

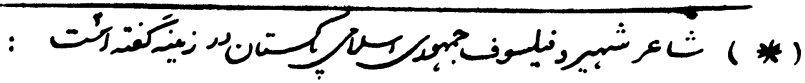

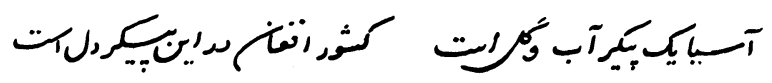

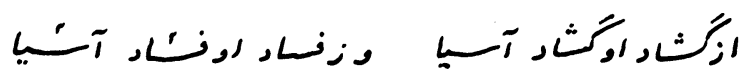




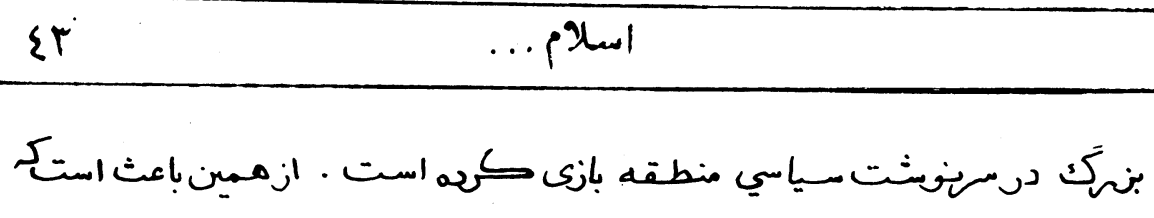

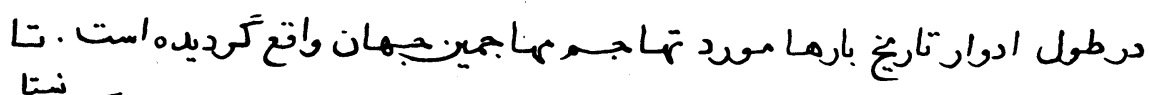

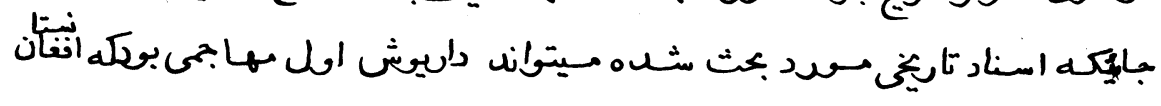

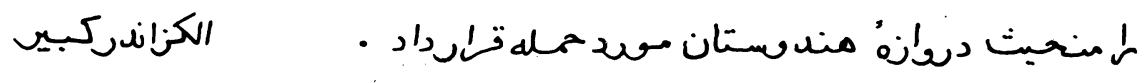

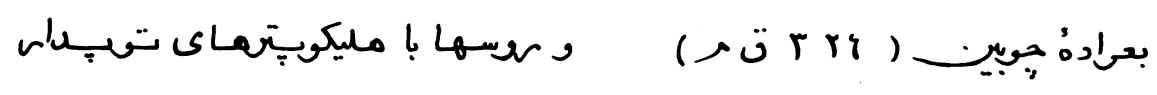

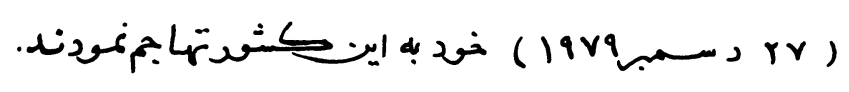

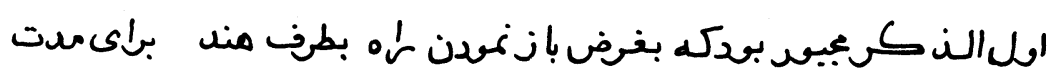

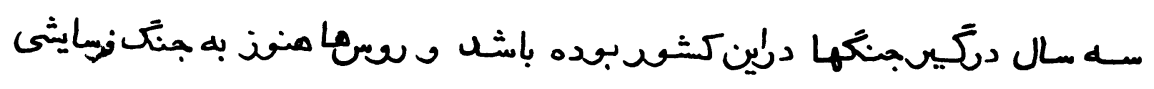

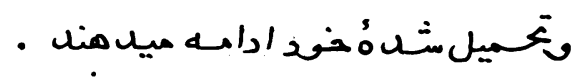

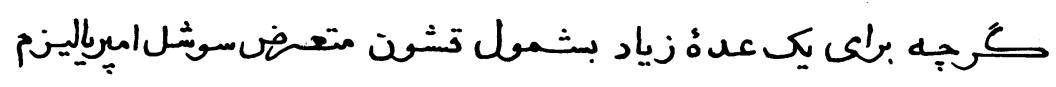

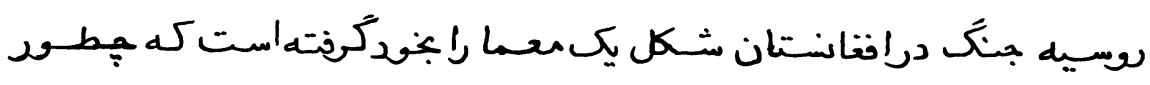

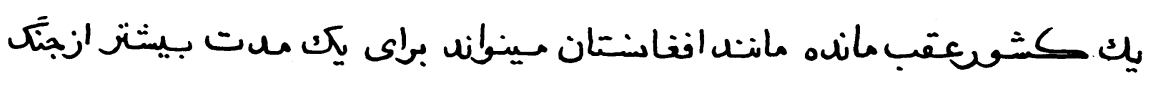

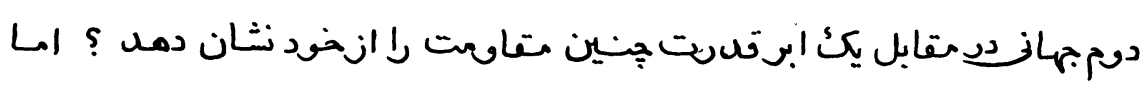

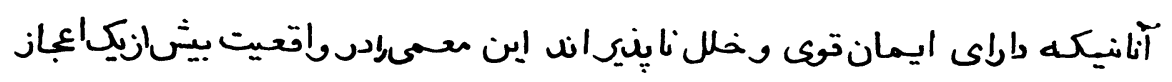

تصن ·r ميدانه -

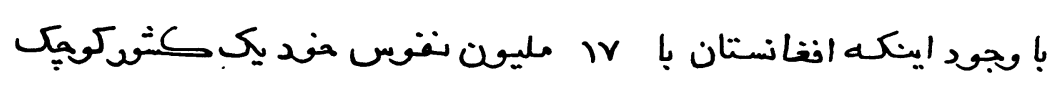

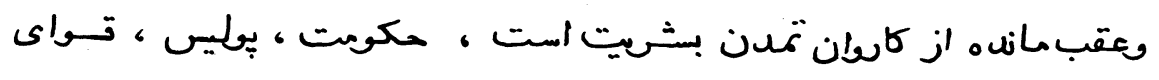

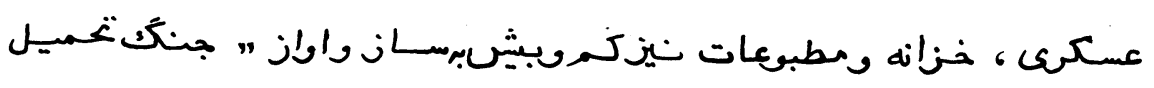

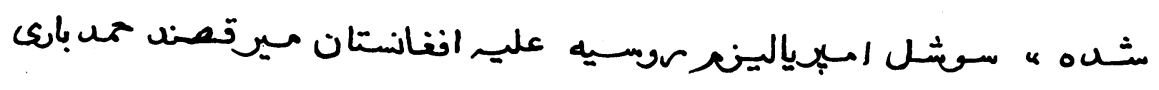




\begin{tabular}{ll}
\hline ق \\
\hline
\end{tabular}

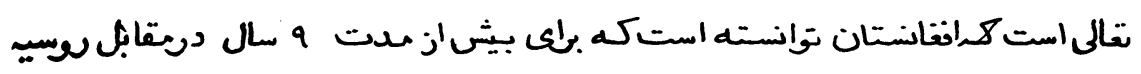

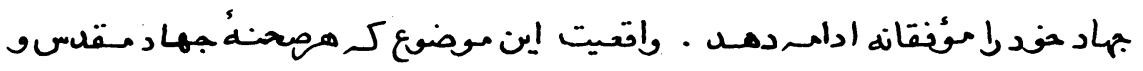

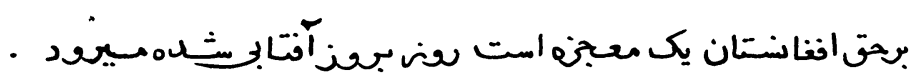

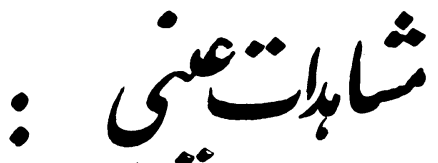

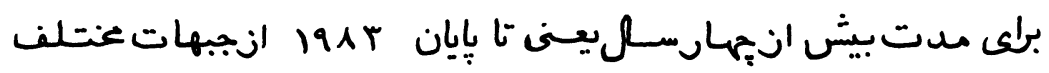

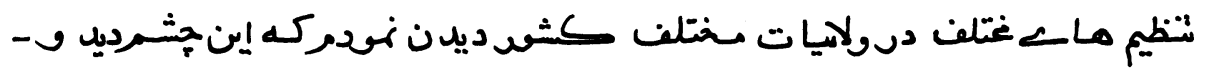

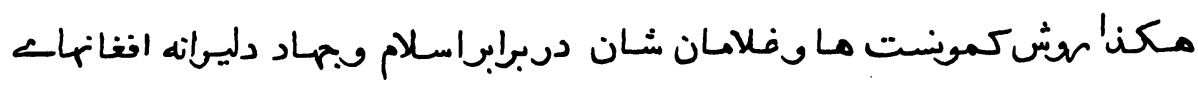

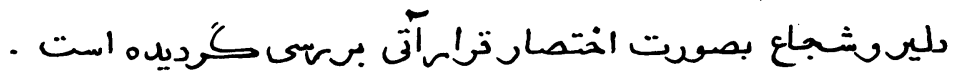

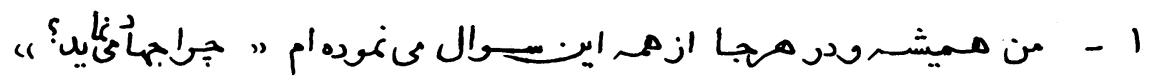

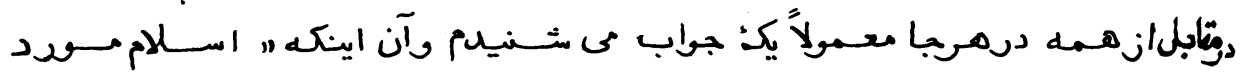

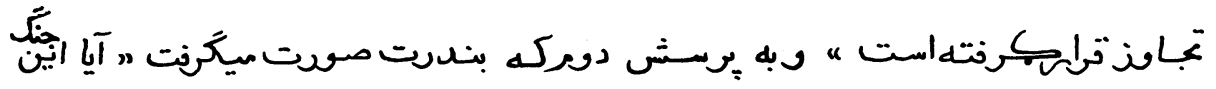

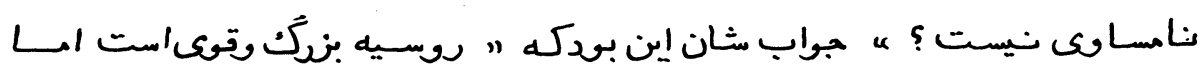

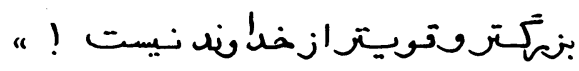

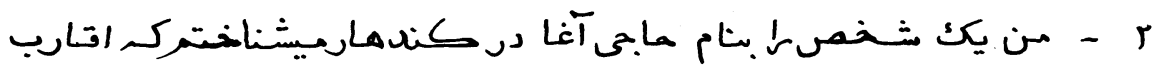

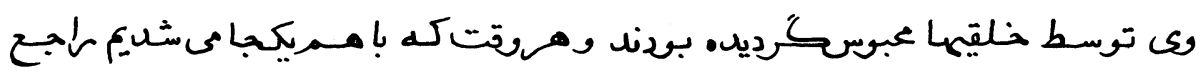

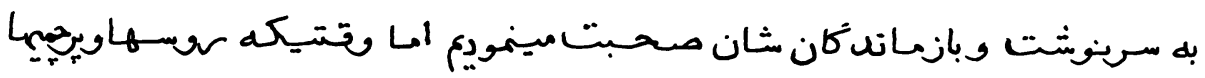

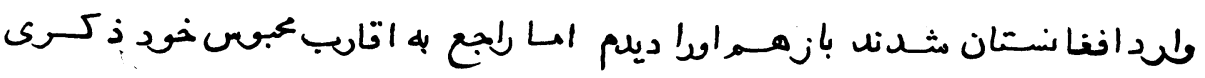




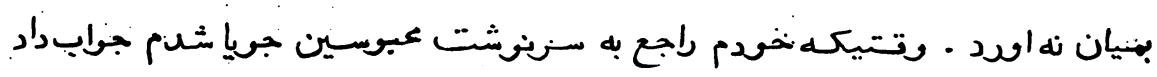

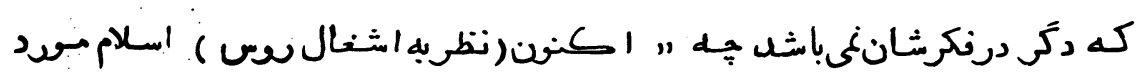

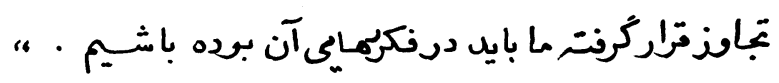

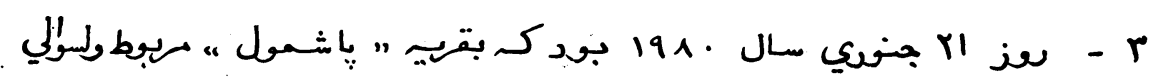

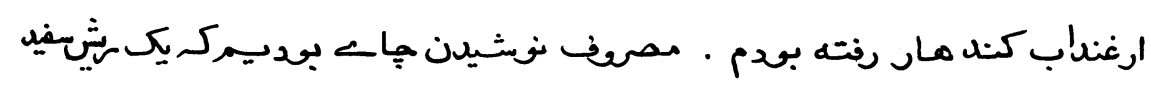

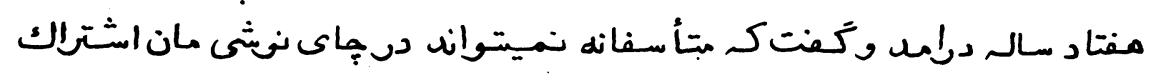

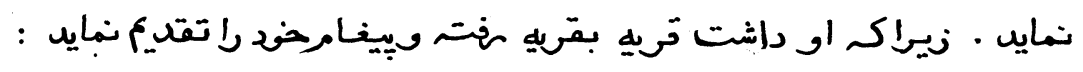

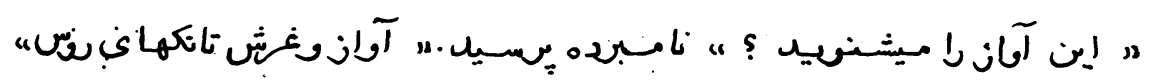

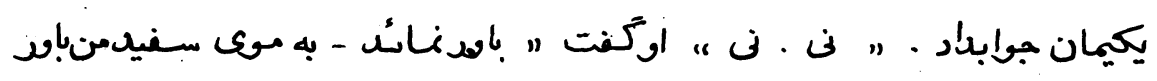

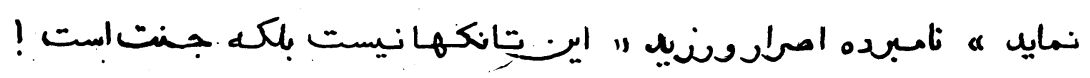

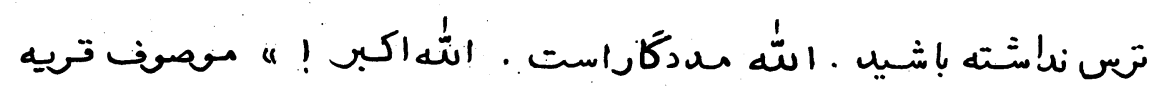

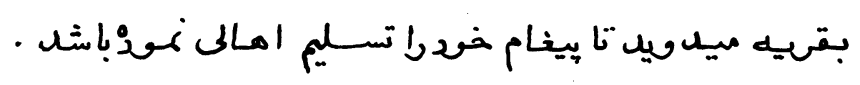

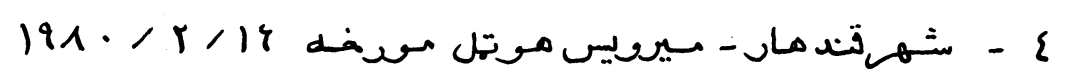

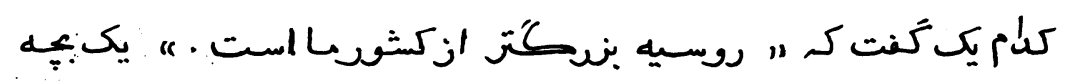

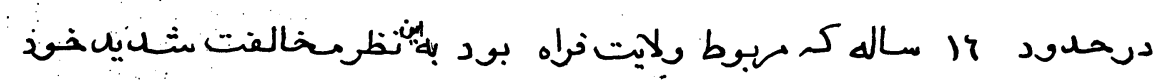

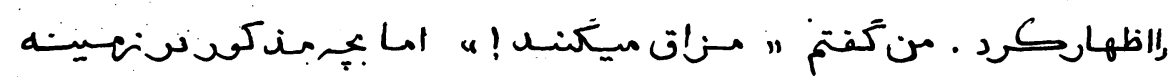

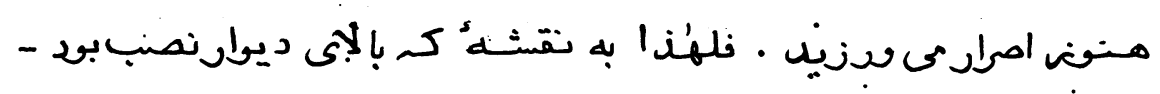

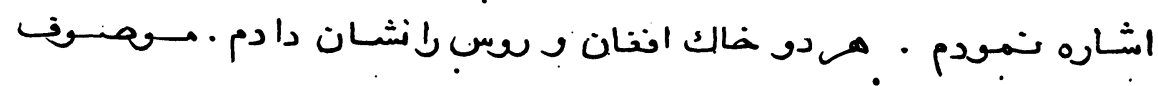

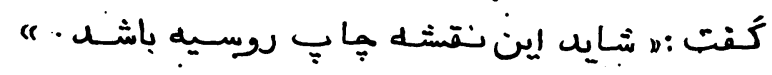




\section{قلم}

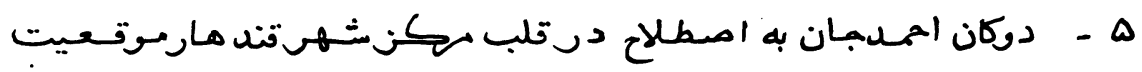

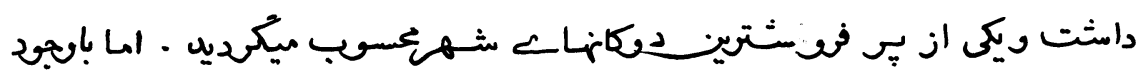

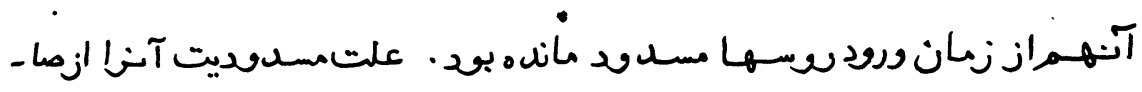

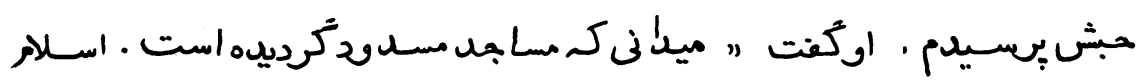

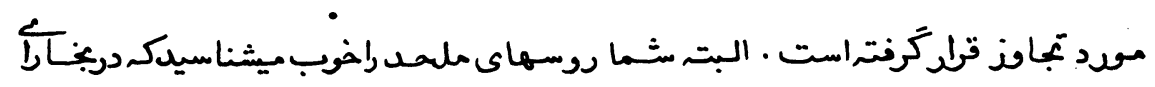

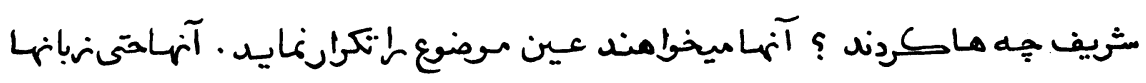

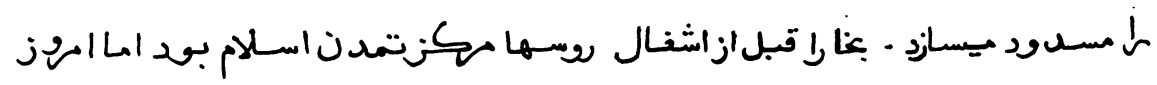

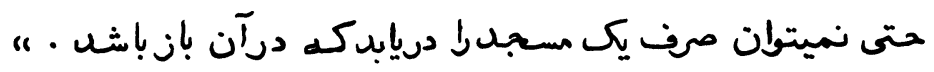

\section{Ar}

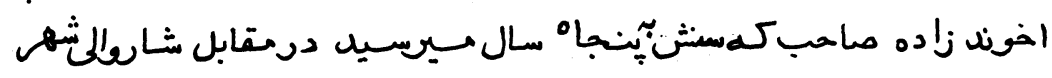

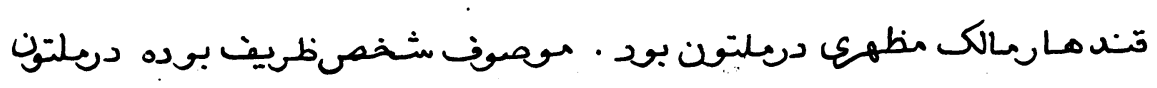

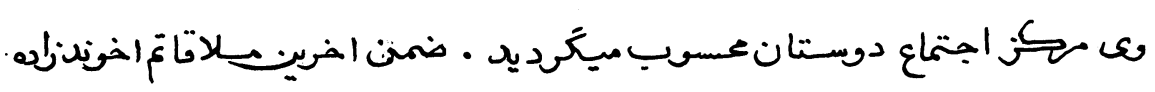

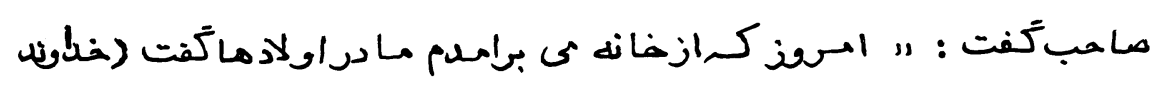

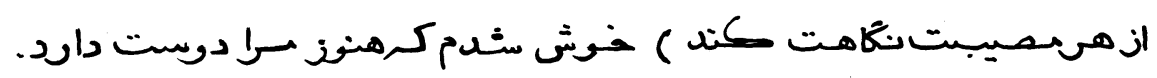

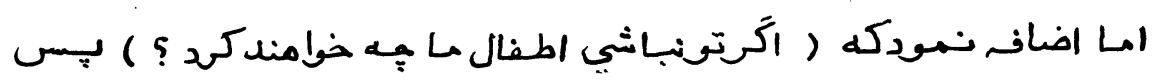

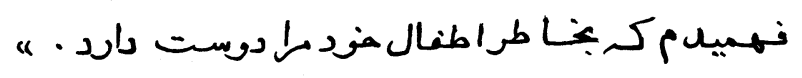

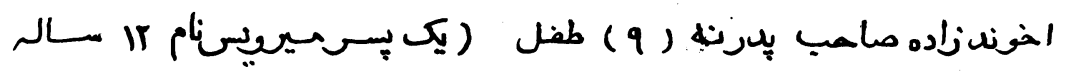

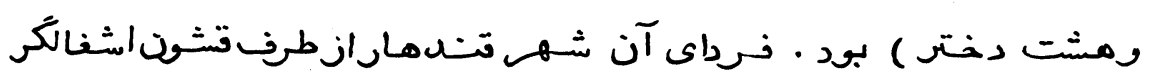




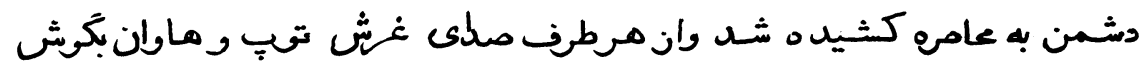

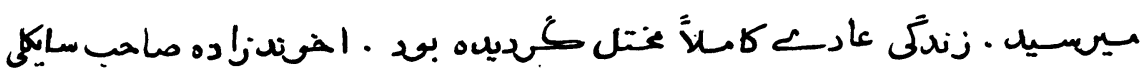

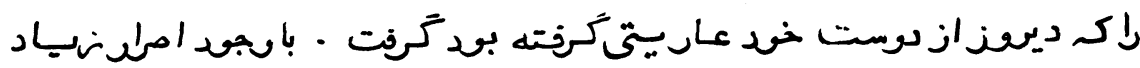

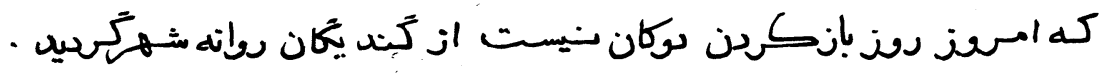

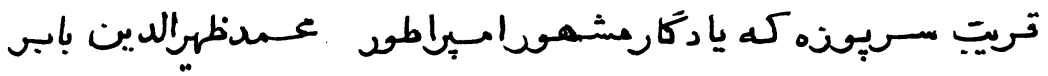

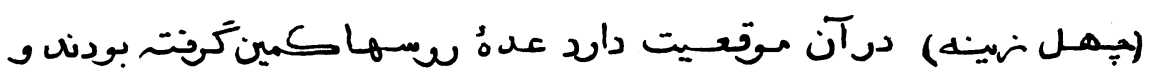

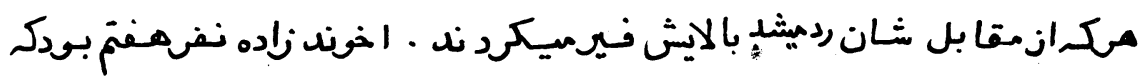

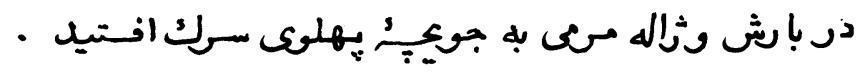

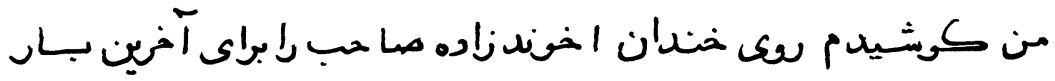

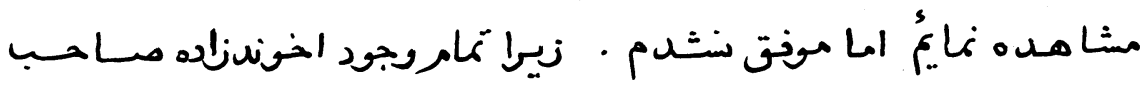

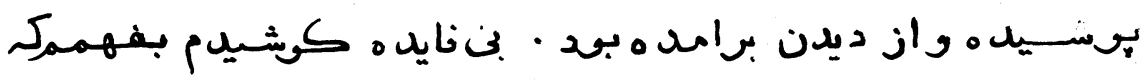

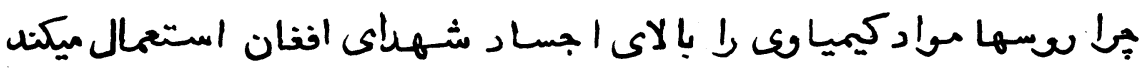

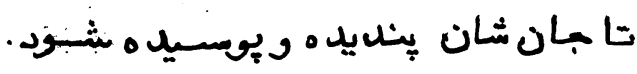

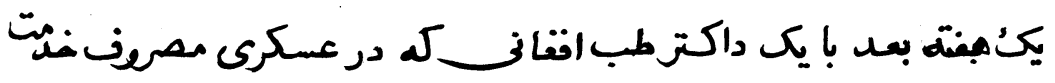

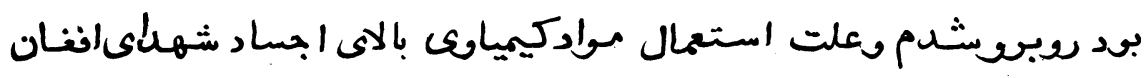

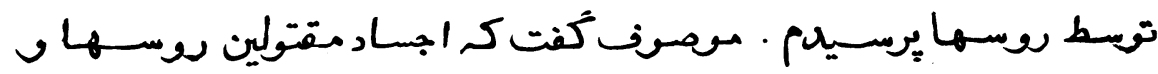

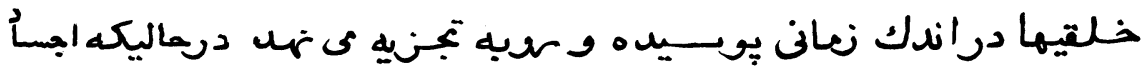

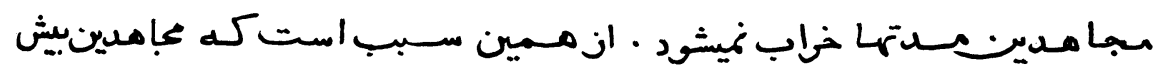

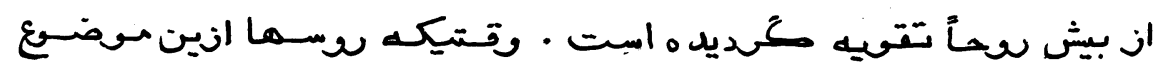




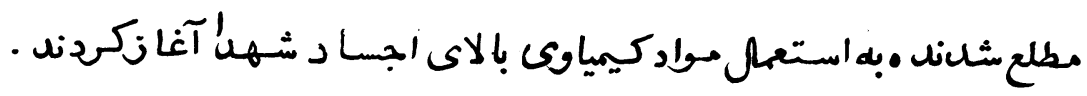

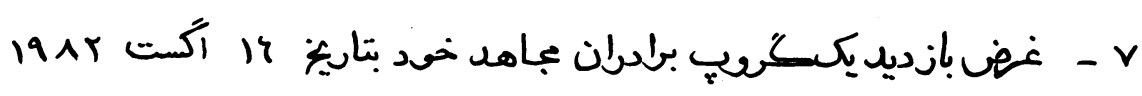

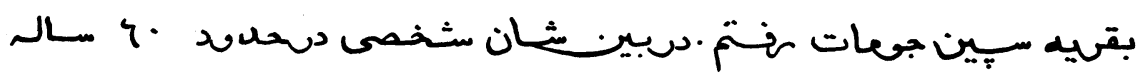

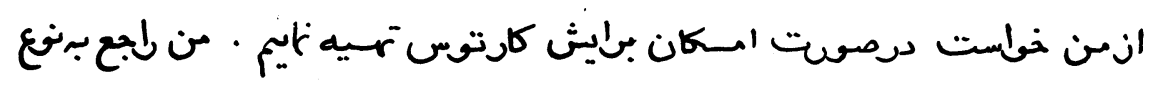

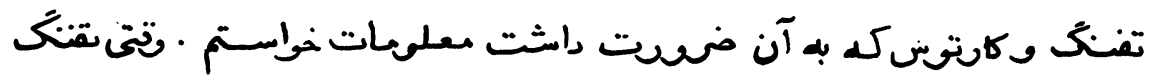

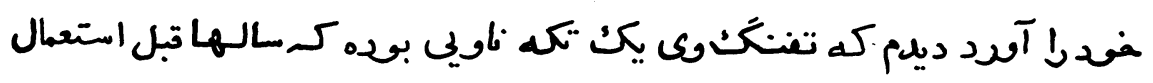

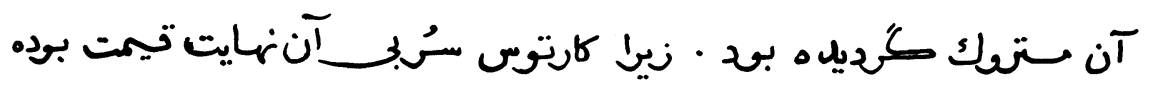

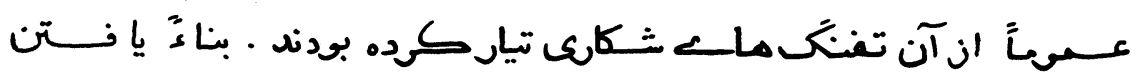

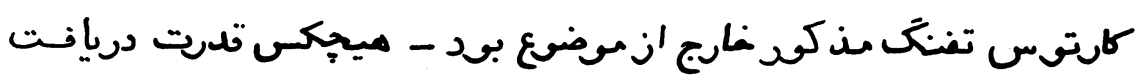

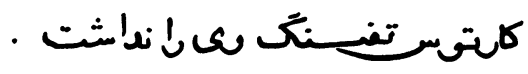

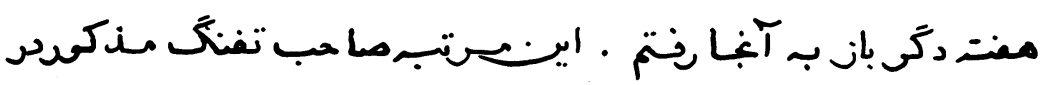

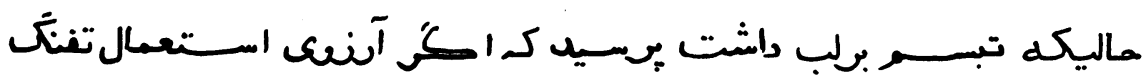

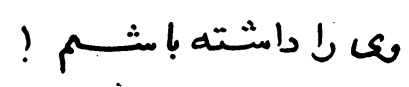

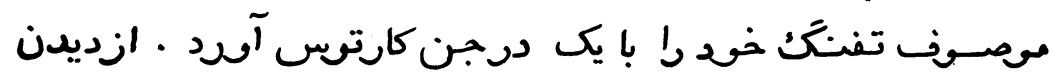

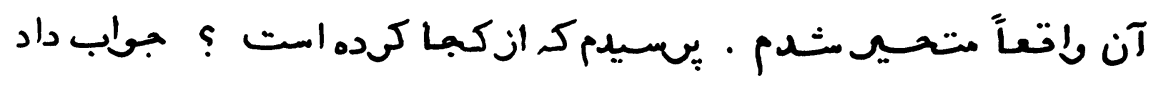

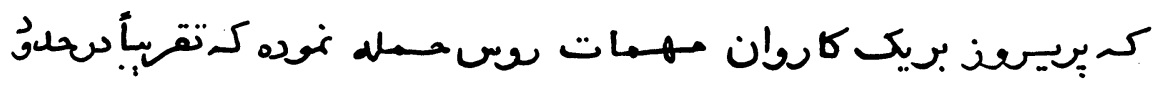

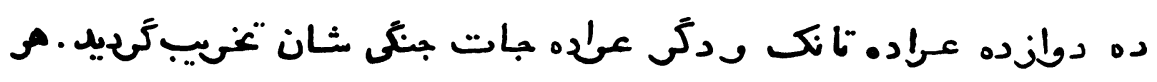

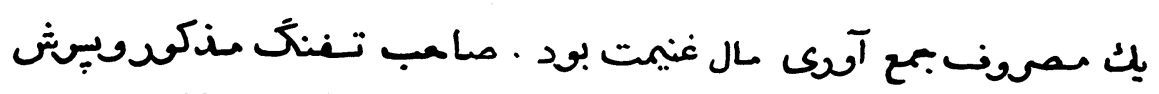

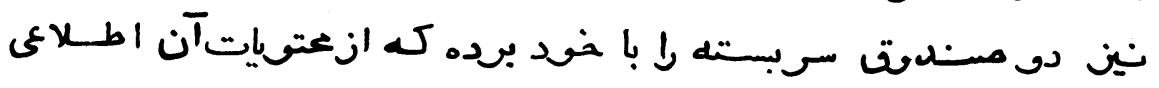



$\sum 9$
اسلام

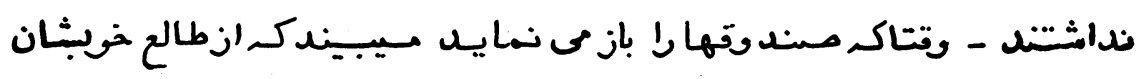

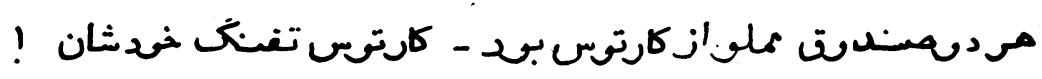

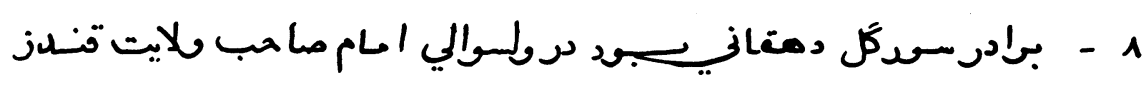

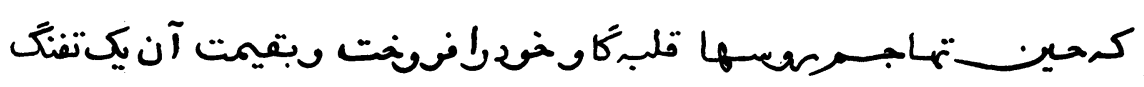

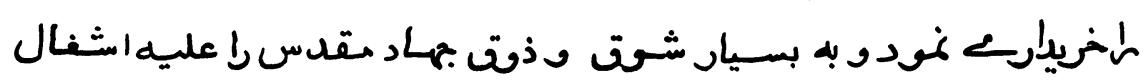

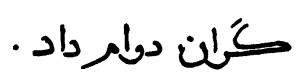

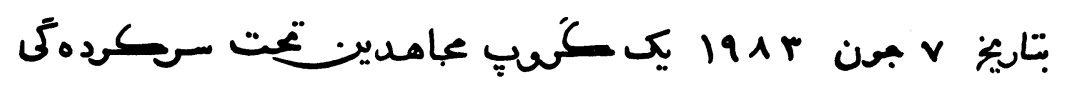

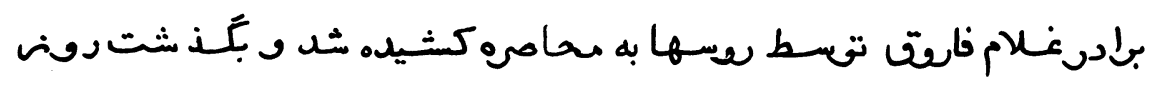

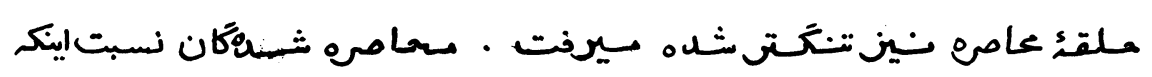

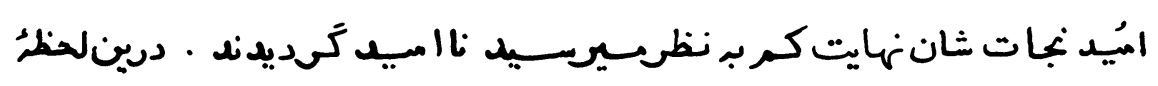

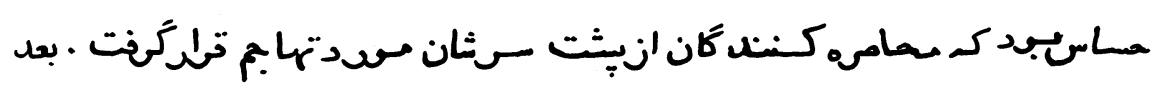

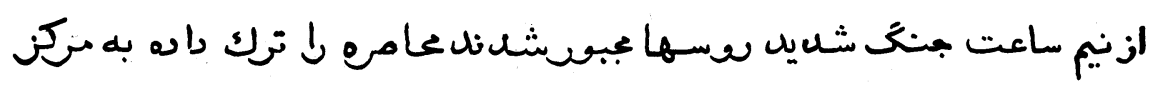

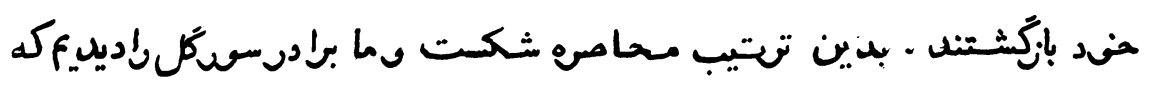

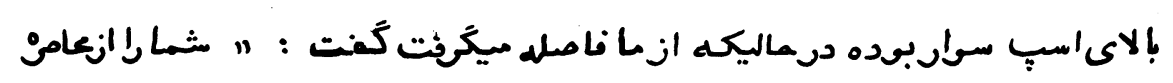

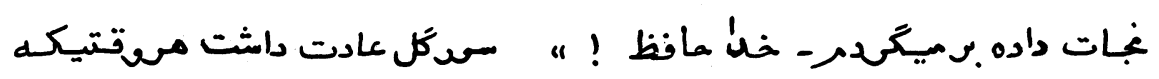

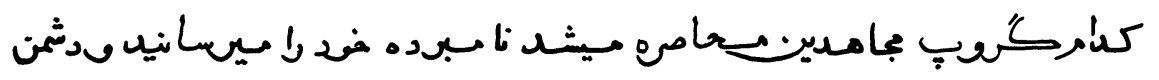

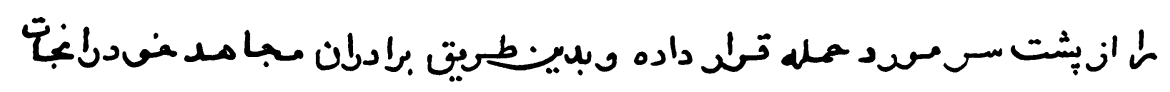

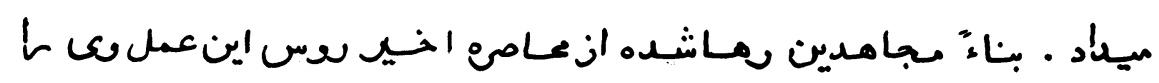

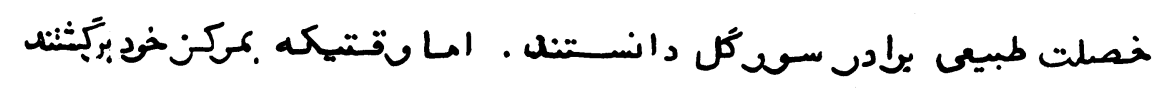




\section{قلم}

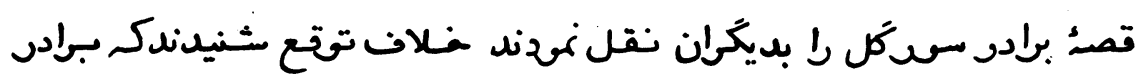

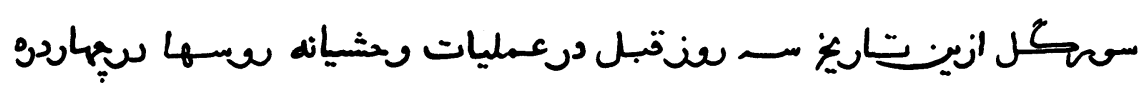

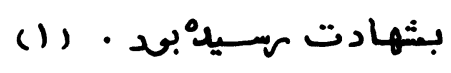

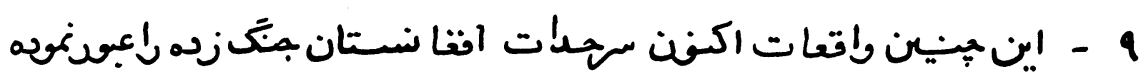

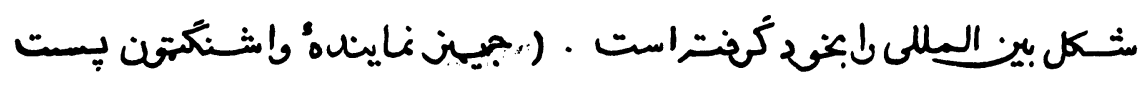

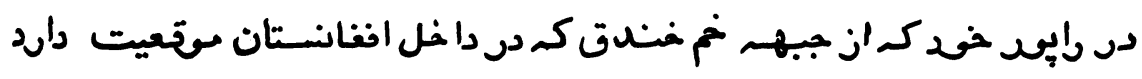

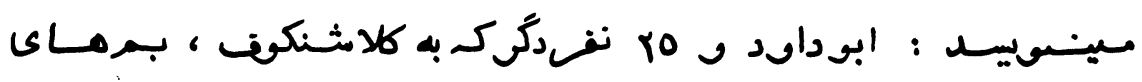

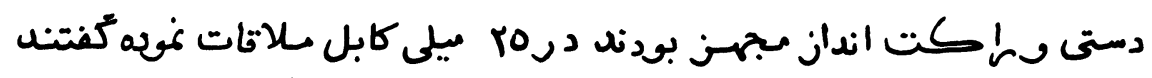

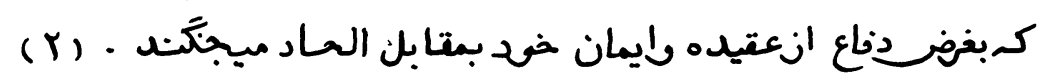

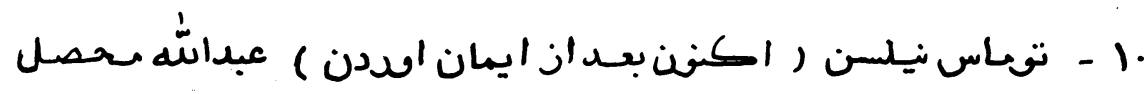

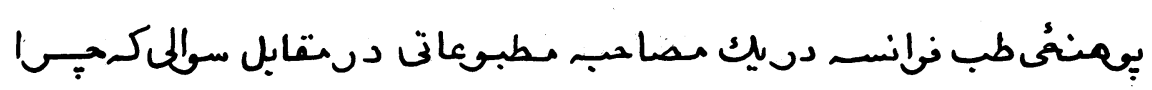

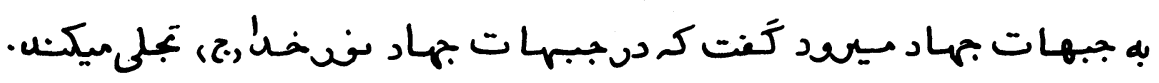

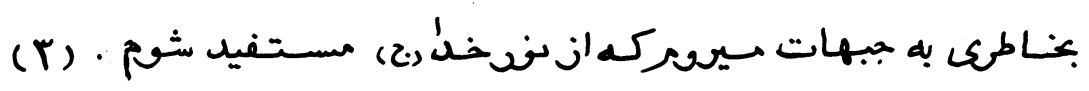


$\Delta 1$ اسمبلام

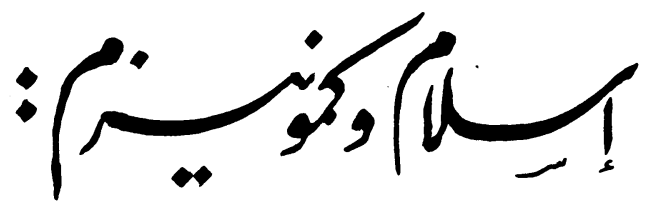

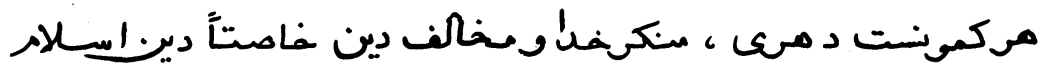

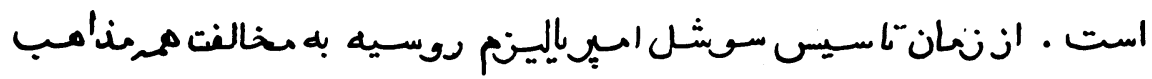

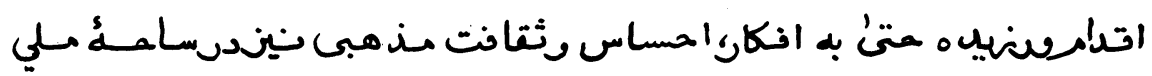

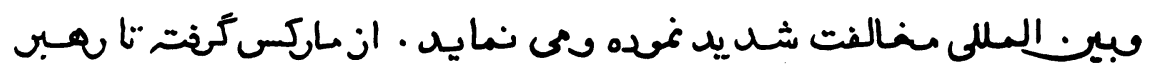

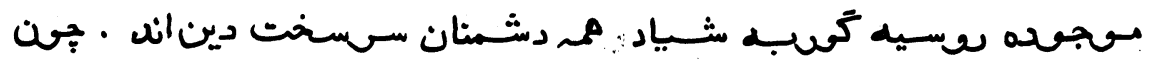

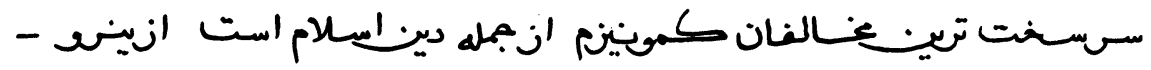

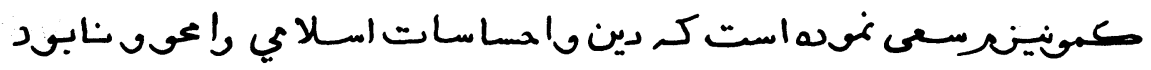

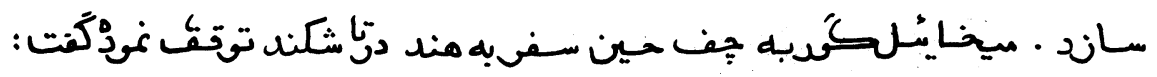

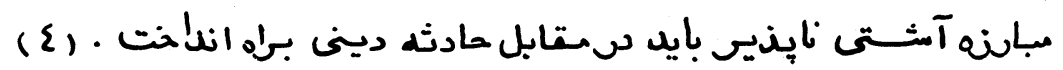

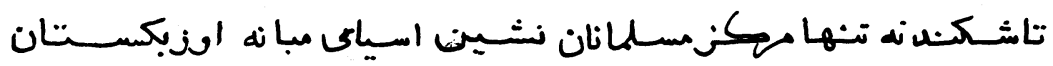

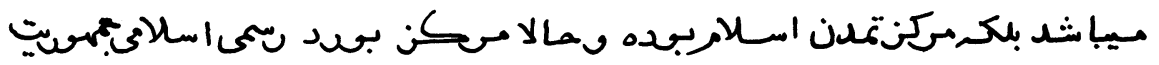

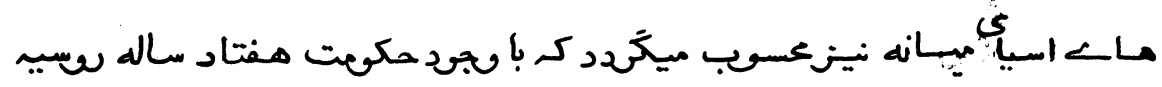

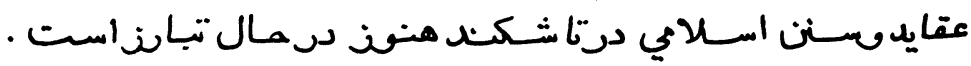

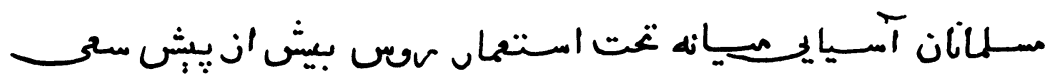

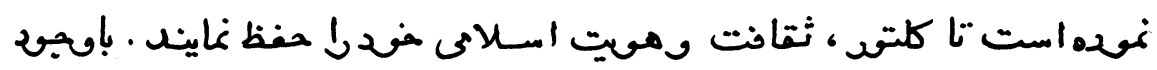

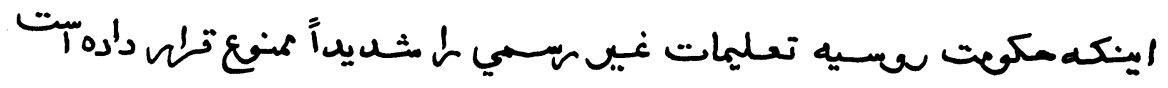

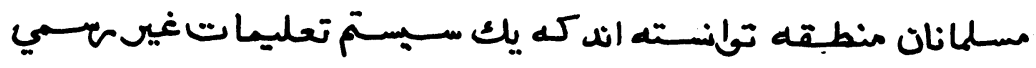




$$
\text { تملم }
$$

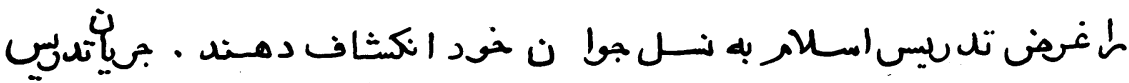

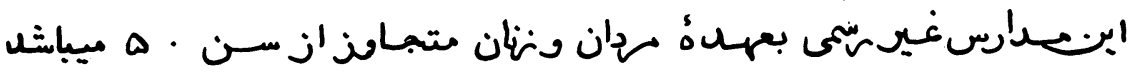

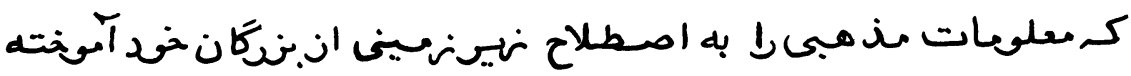

(D) اند (D)

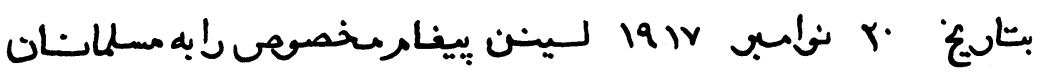

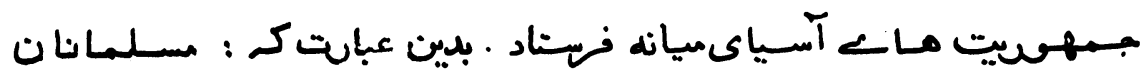

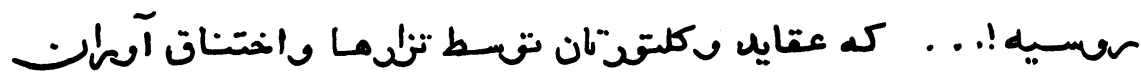

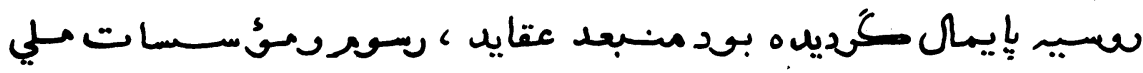

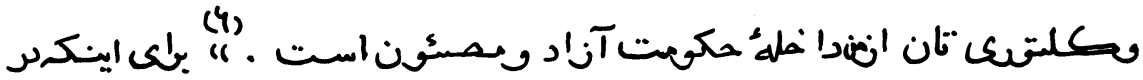

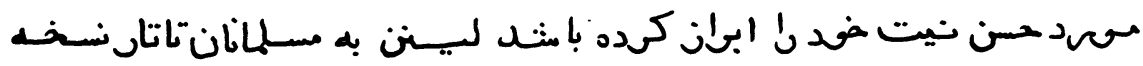

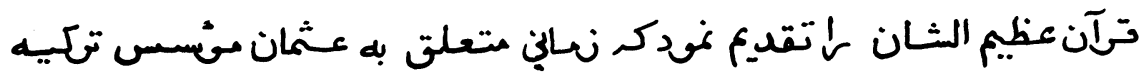

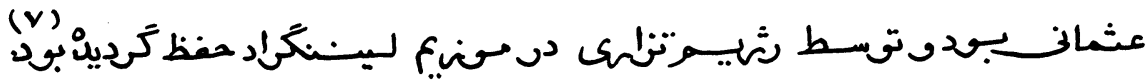

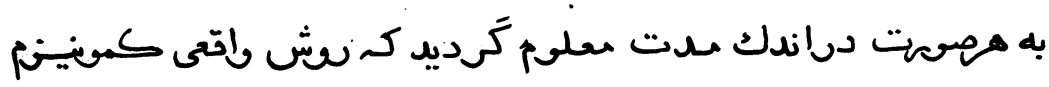

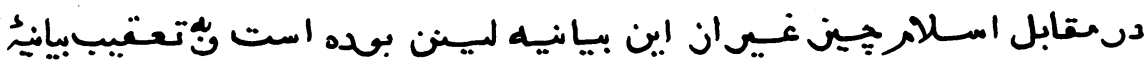

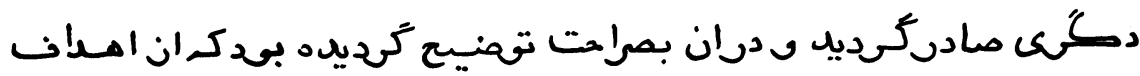

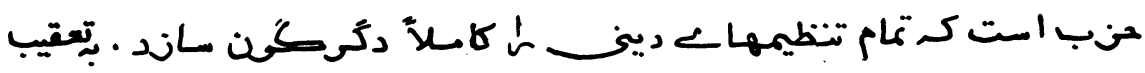

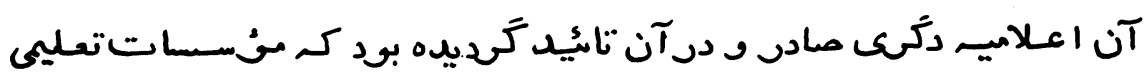

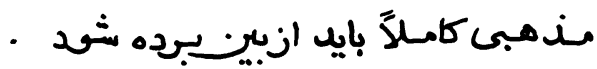

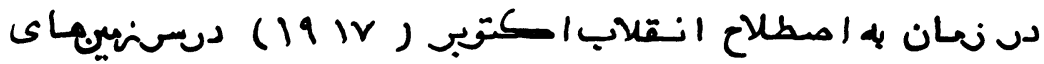




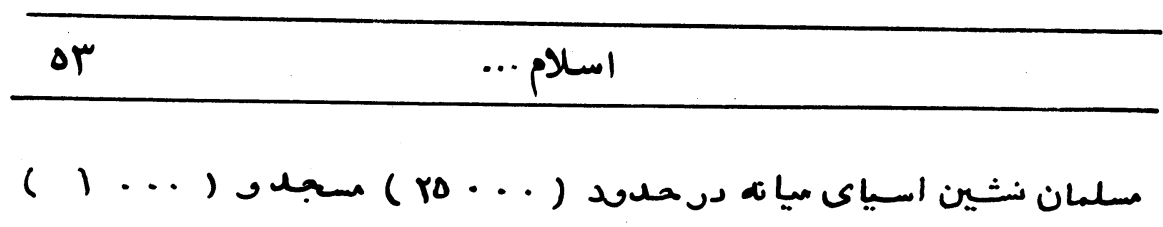

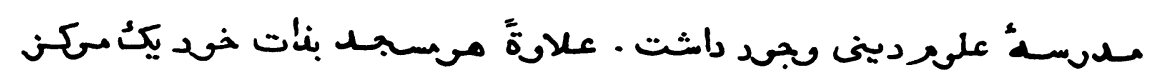

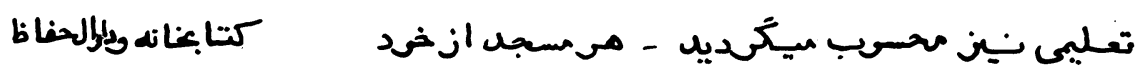

(A) .

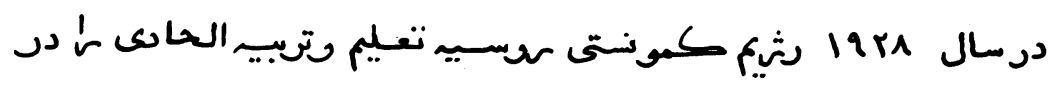

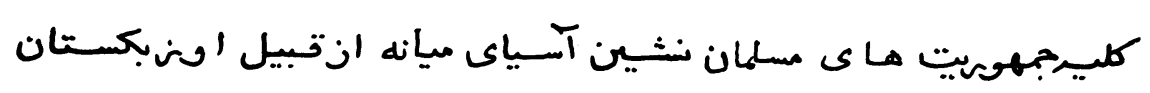

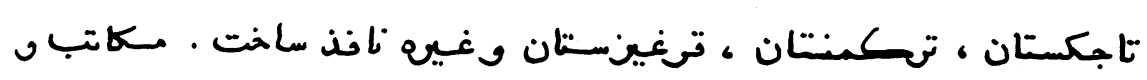

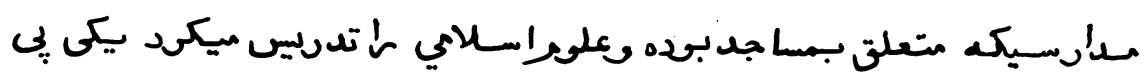

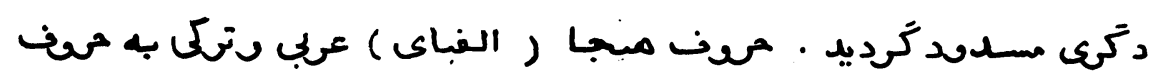

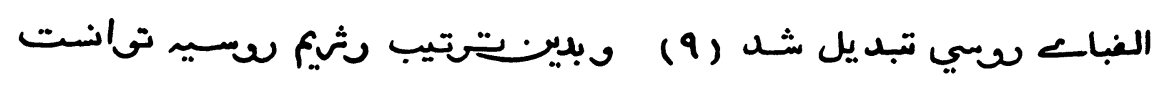
كـارتباط نسـل جملن مسلمانان آمسياى ميانه لا به علىم وثقا نت اسلامي

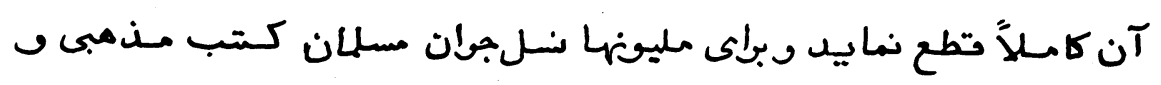

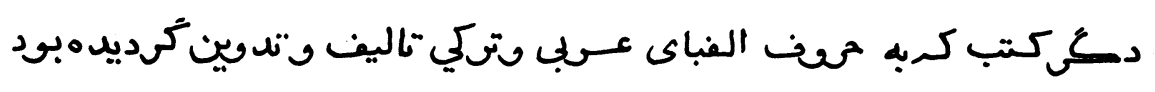

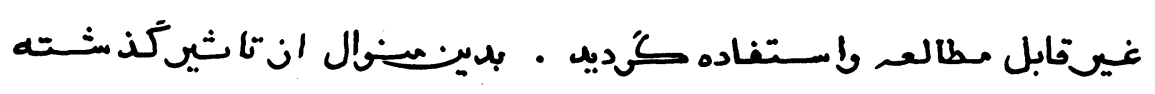

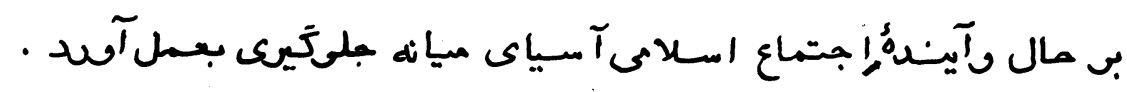

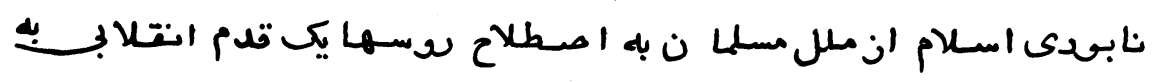

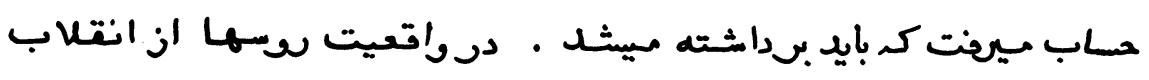

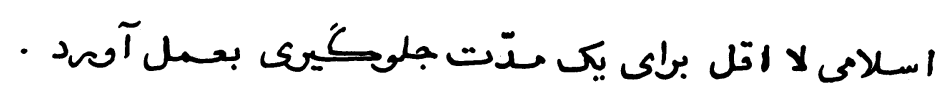

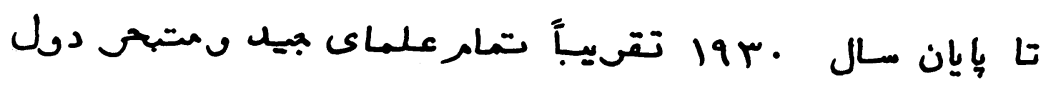




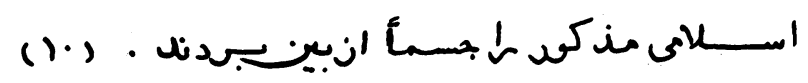

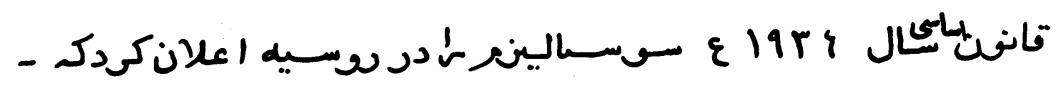

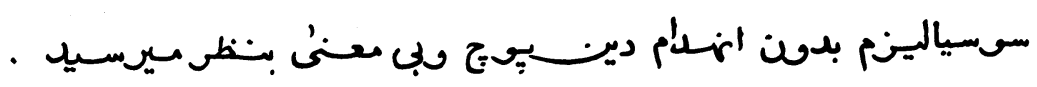

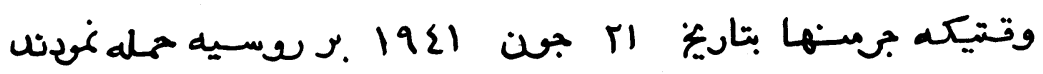

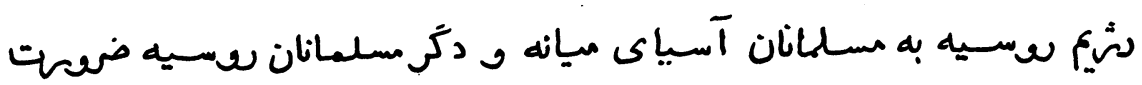

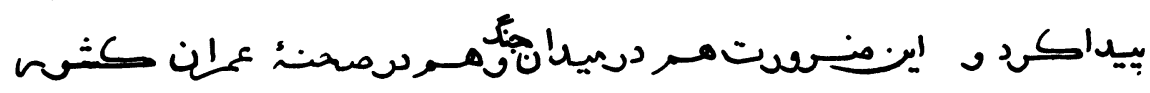

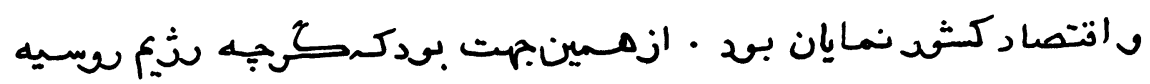

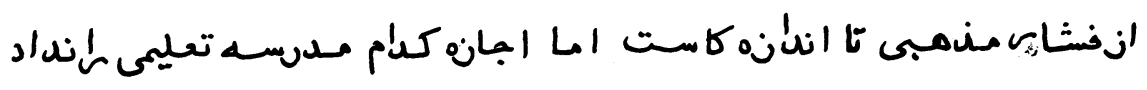

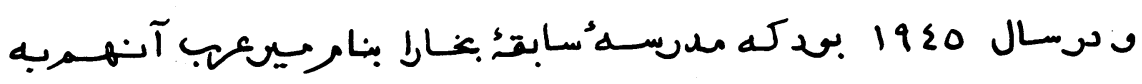

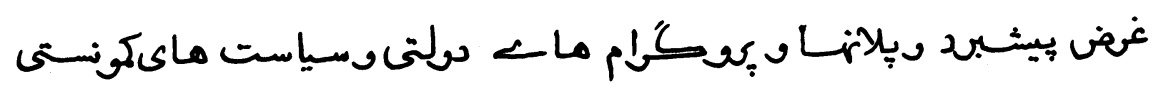

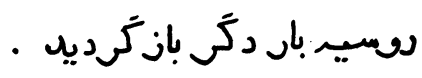

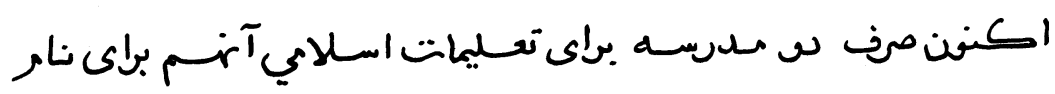

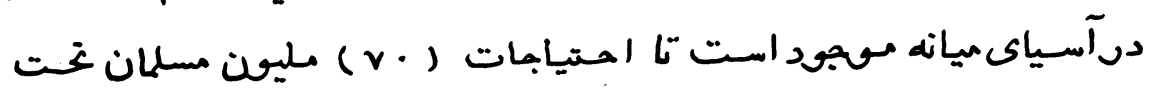

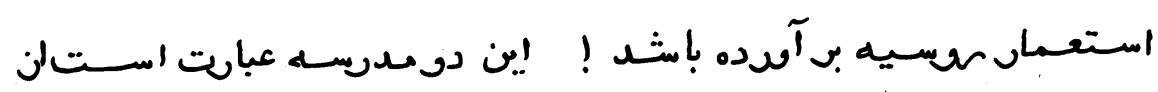

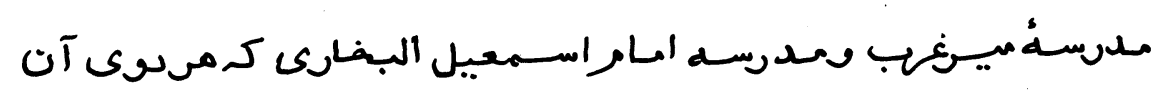

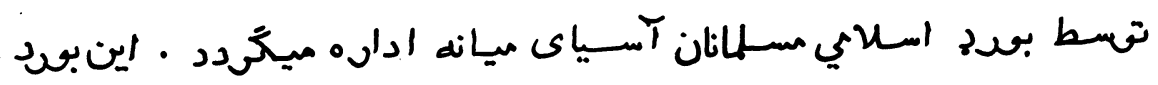

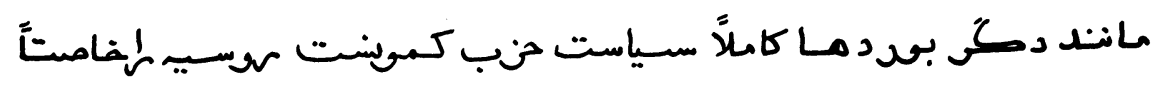

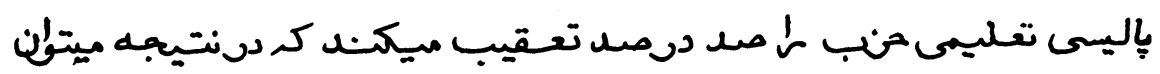

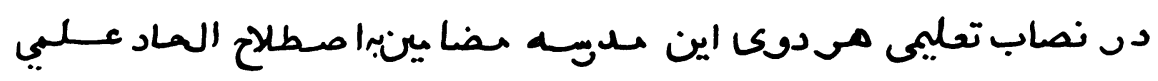




os $\cdots p x^{\prime \prime l}$

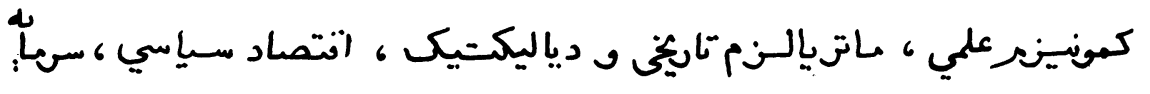

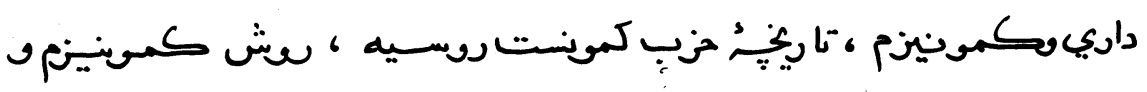

غيع را يانت .

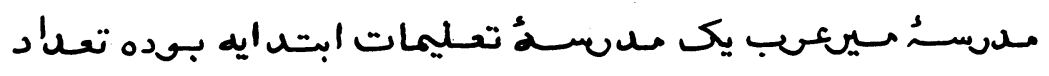

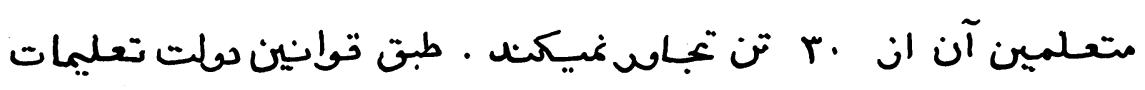

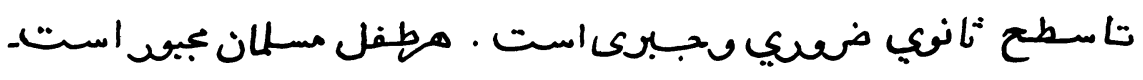

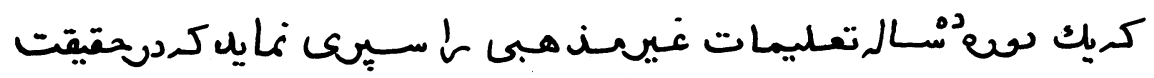

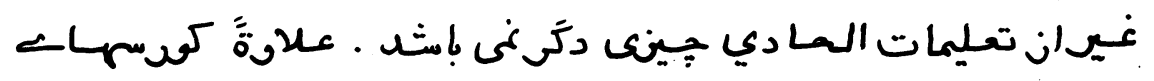

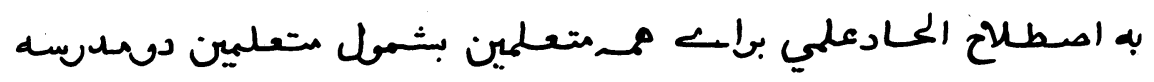

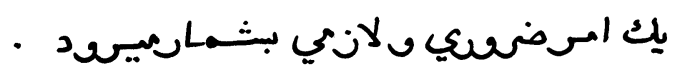

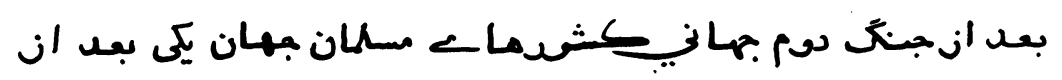

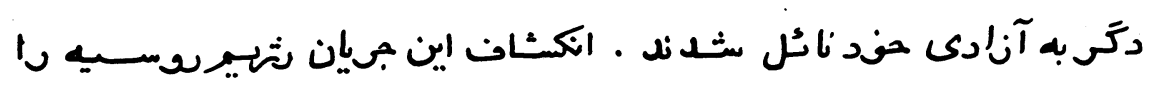

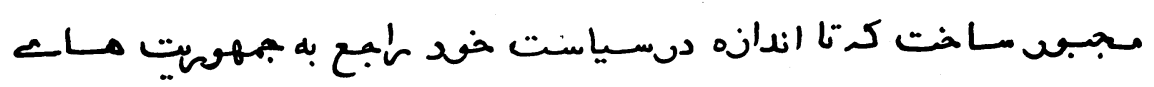

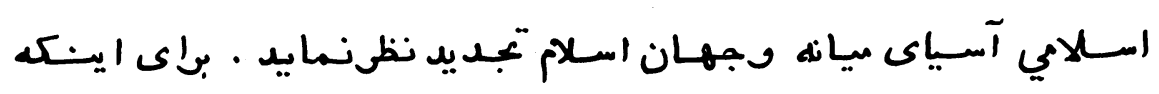

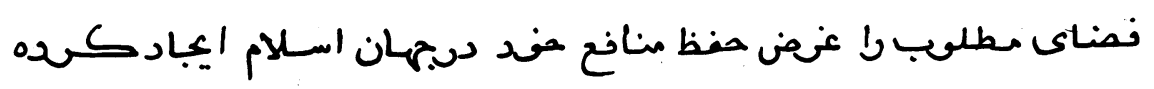

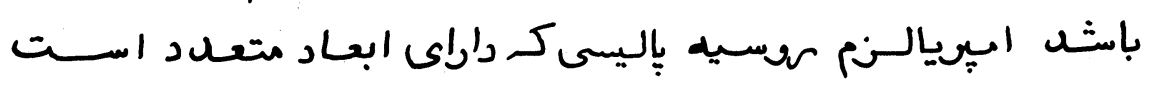

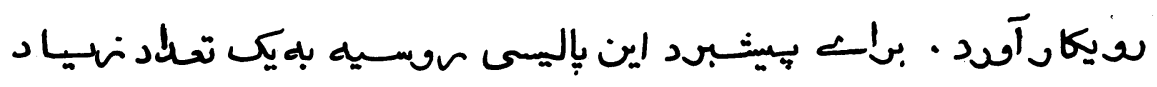

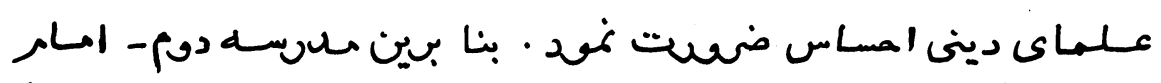

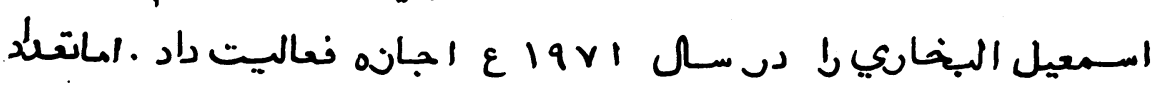




\section{تلم}

oY

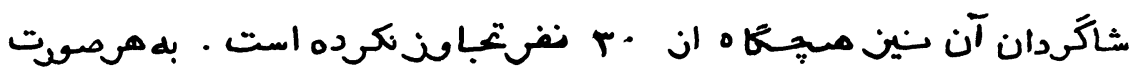

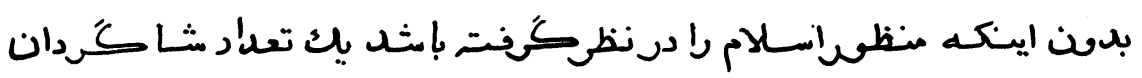

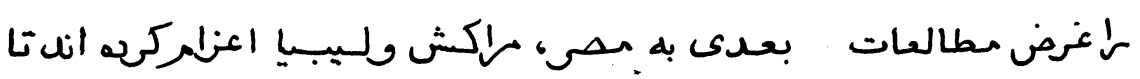

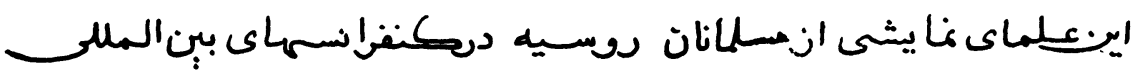

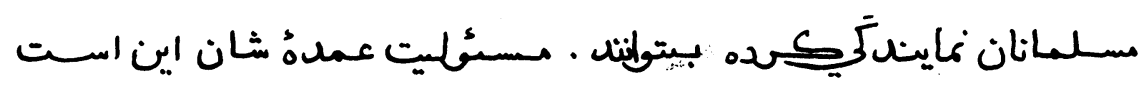

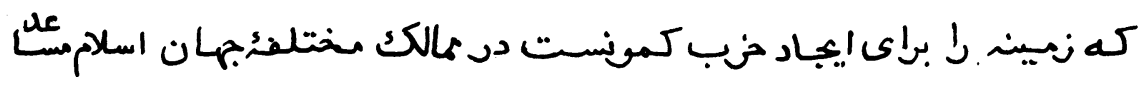

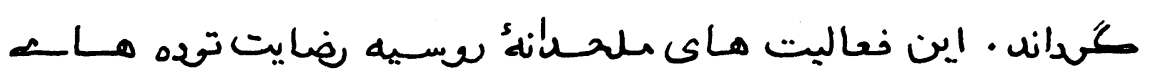

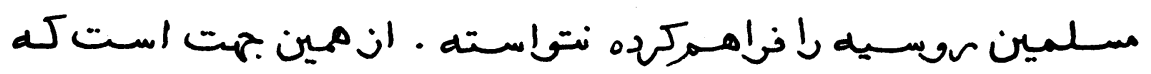

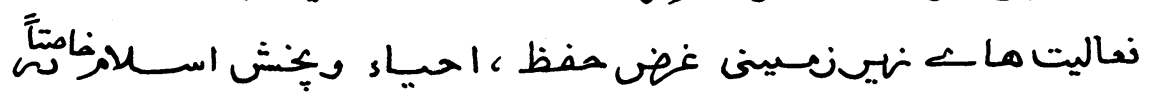

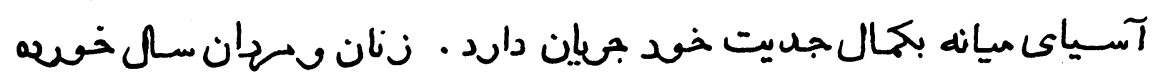

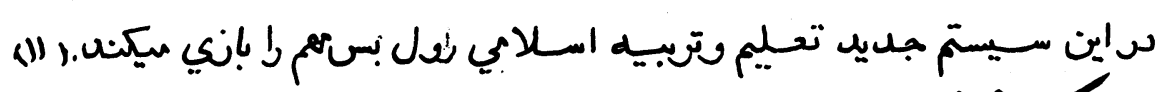

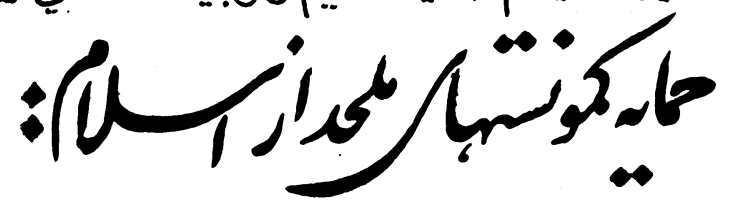

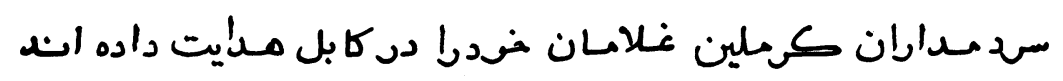

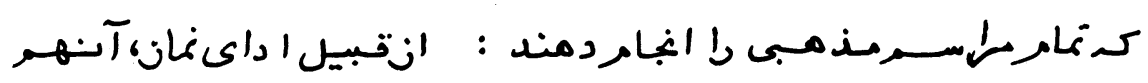

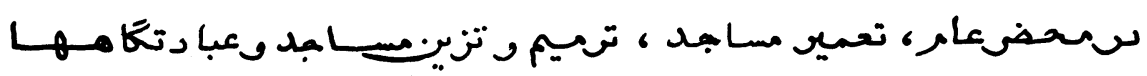

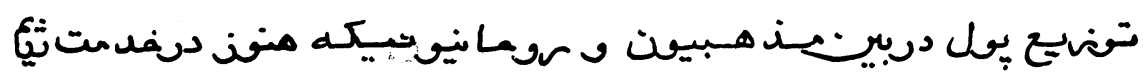

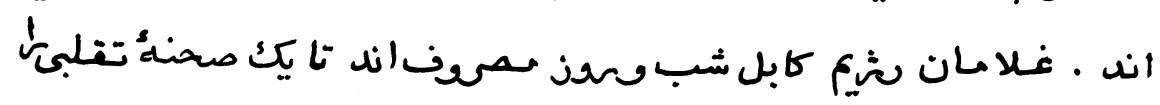

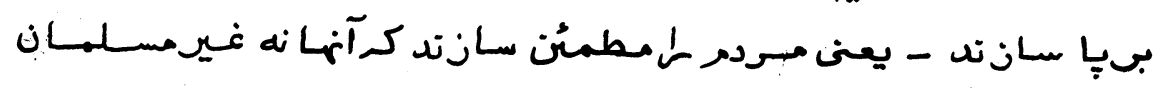




\begin{tabular}{|c|c|}
\hline$\Delta V$ & اسلام ... \\
\hline
\end{tabular}

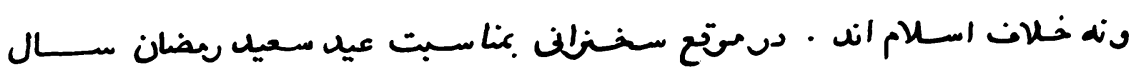
: 191.

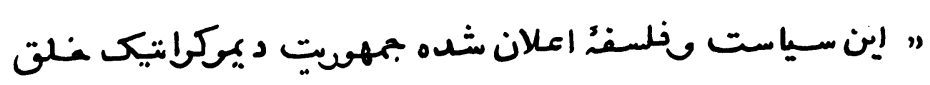

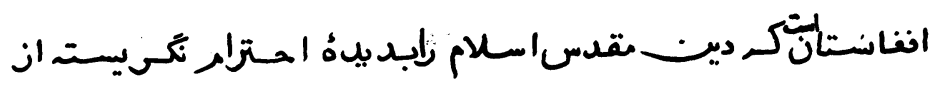

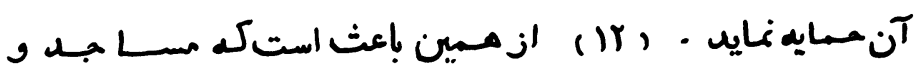

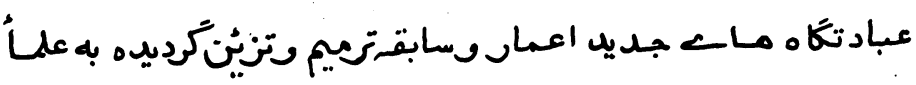

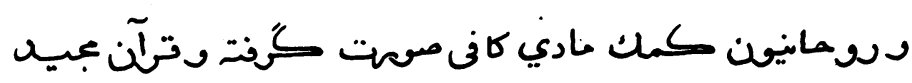

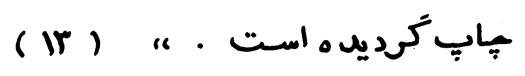

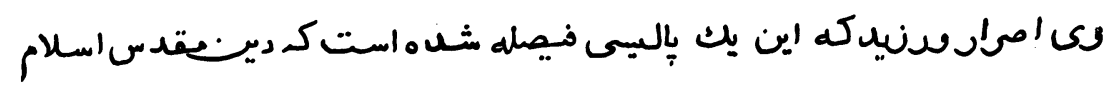

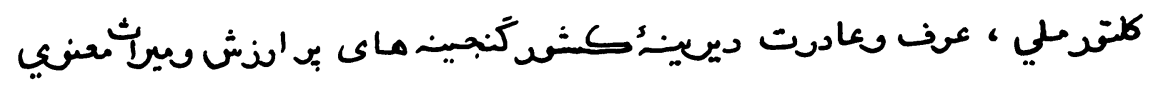

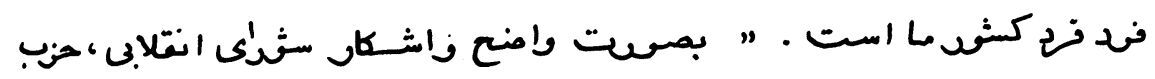

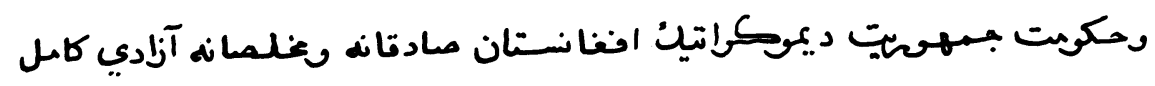

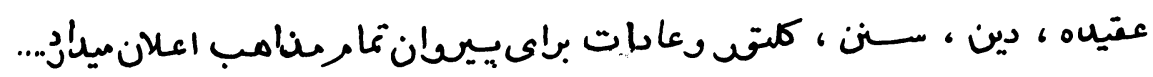

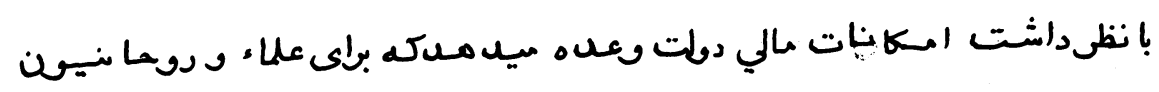

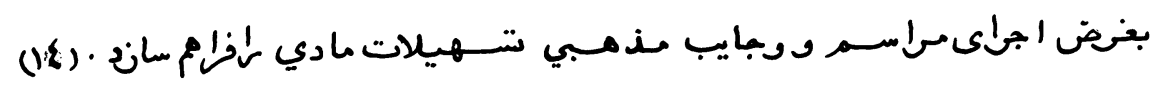

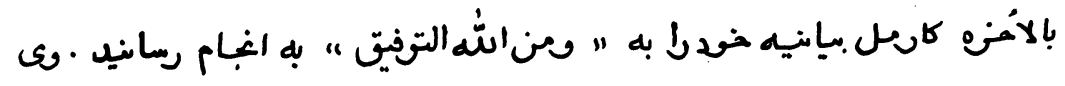
دهمقع انتحاح ستولى به امطلاح علما، وموحانيفنكت :

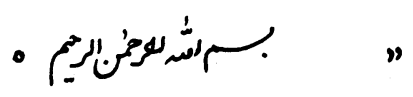

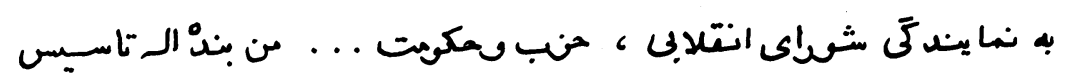




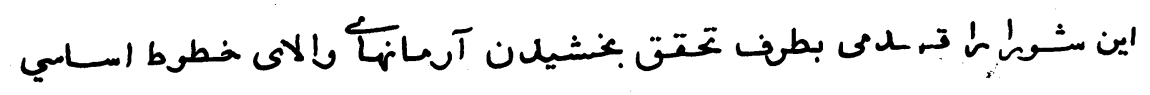

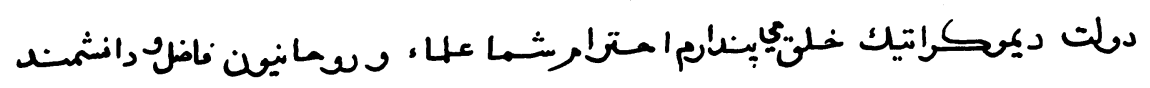

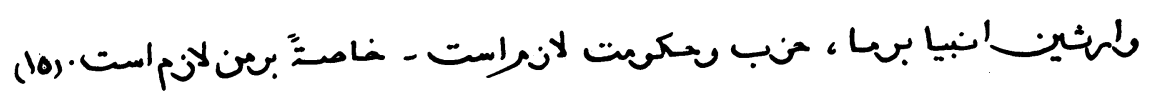

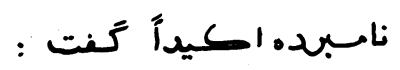

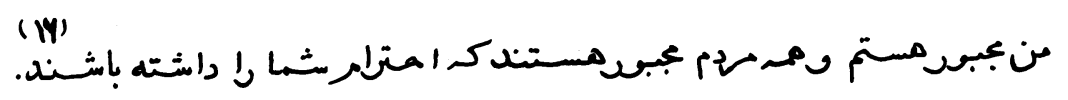

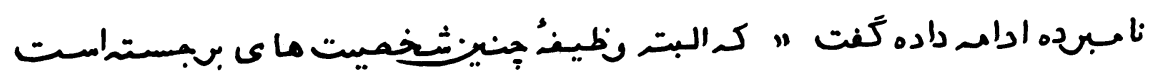

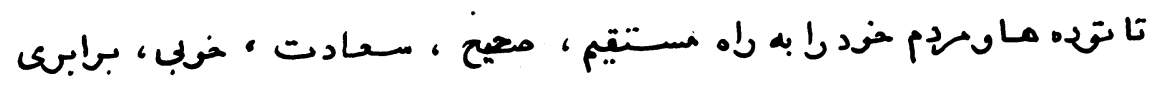

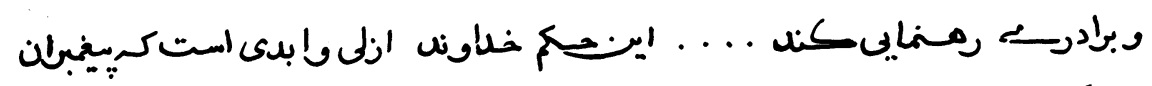

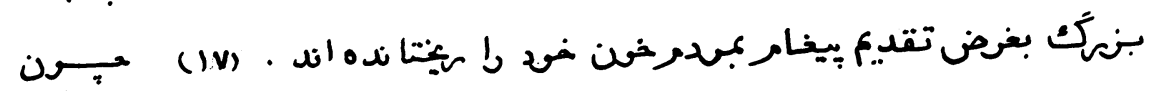

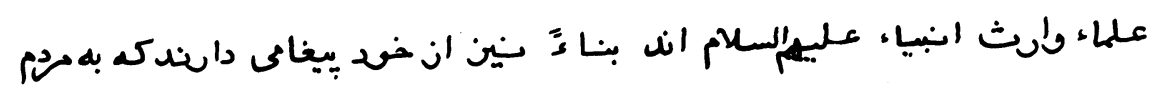

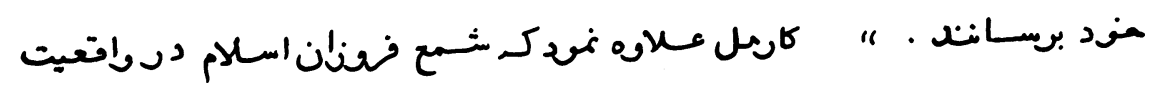

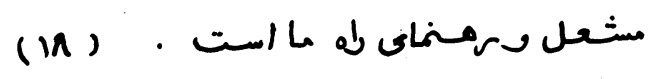

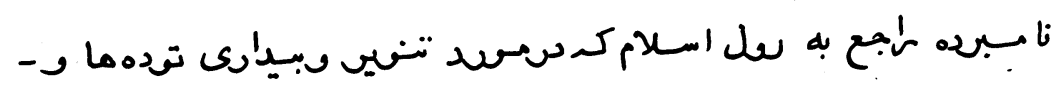

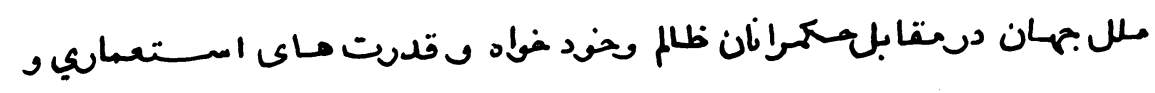

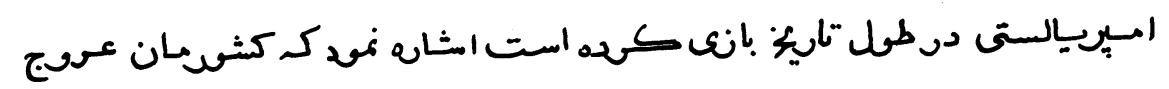

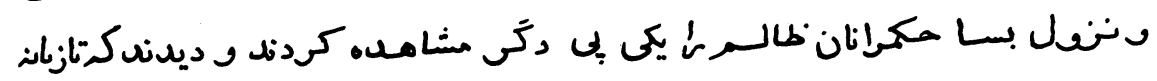

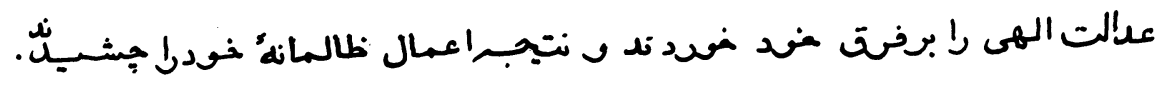

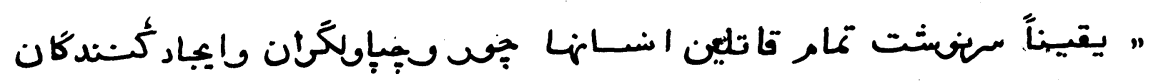

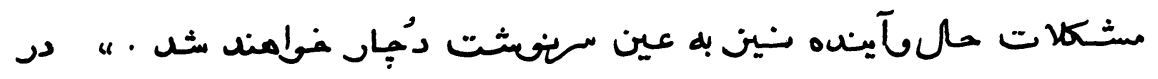




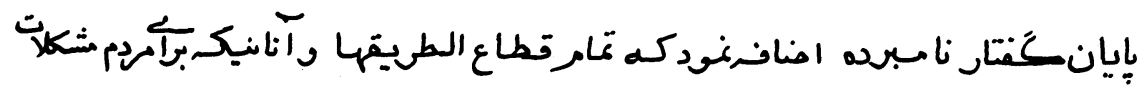

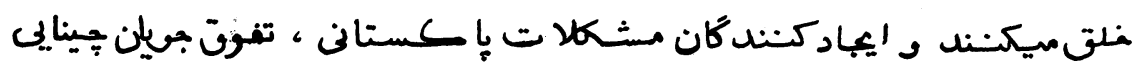

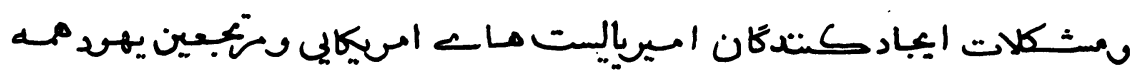

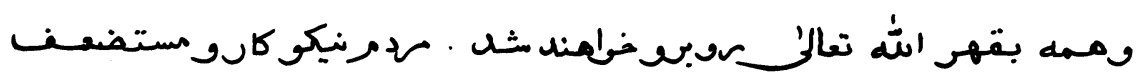

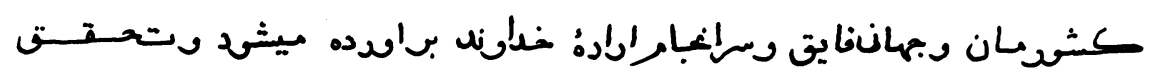

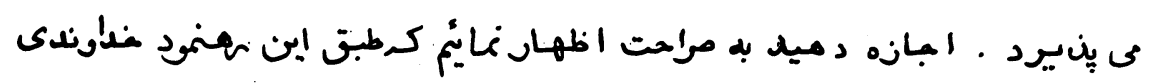

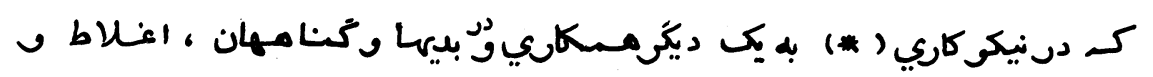

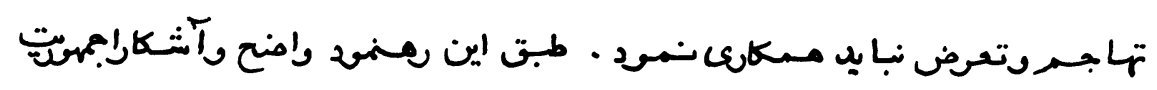

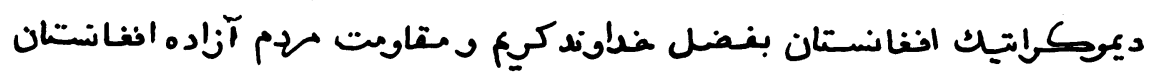

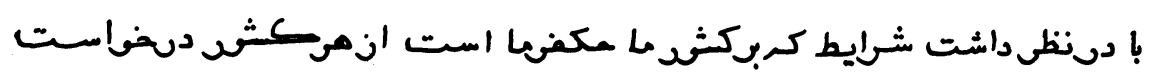

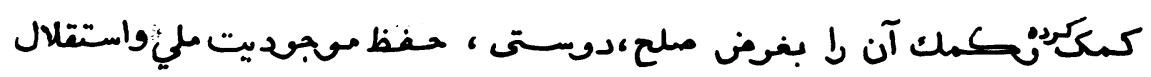

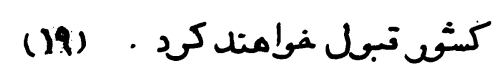

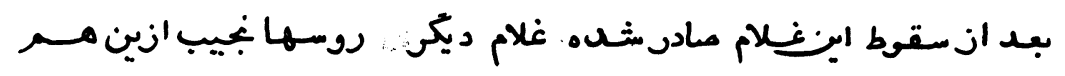

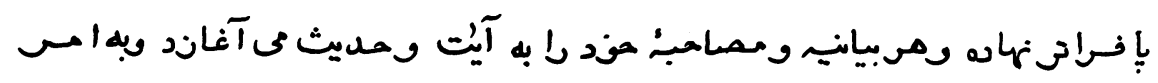

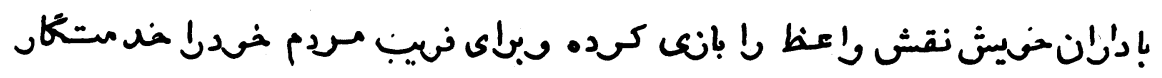
اسـلام تلملاد مى نمايل

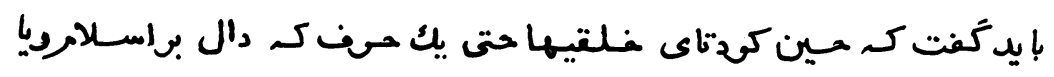

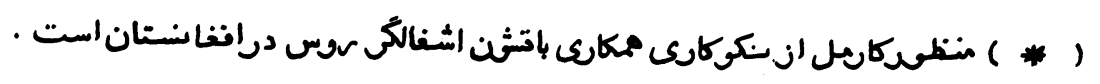




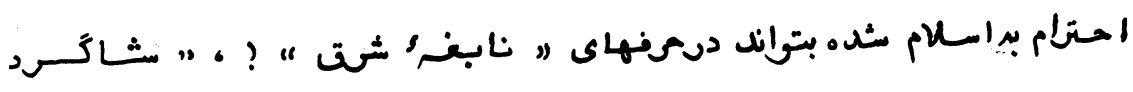

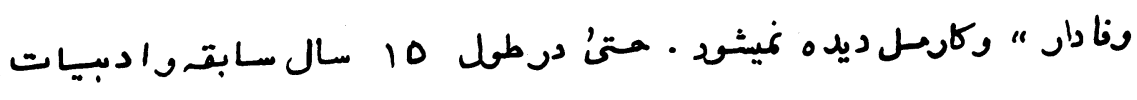

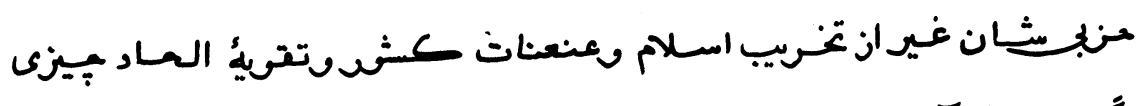

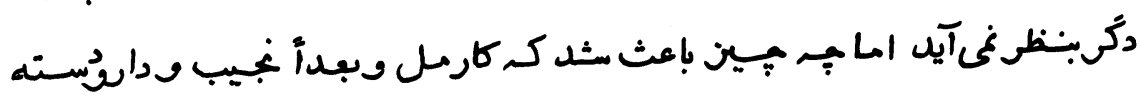

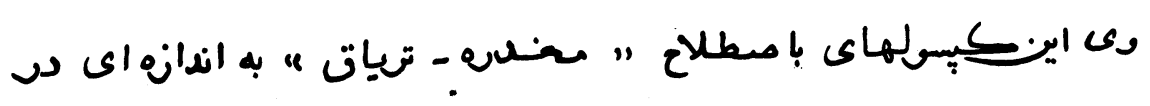

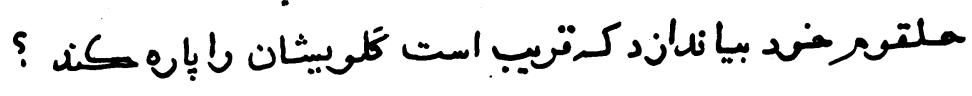

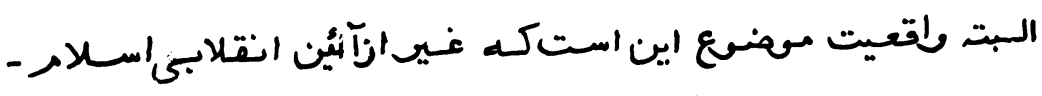

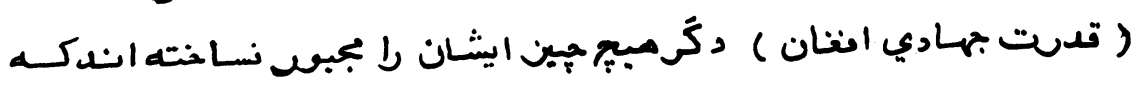

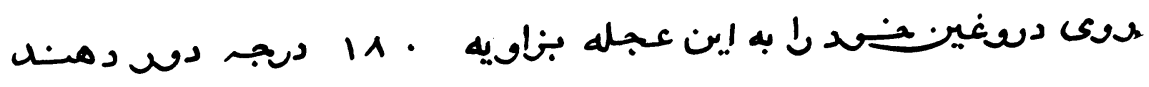

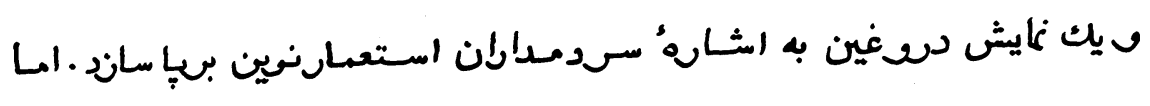

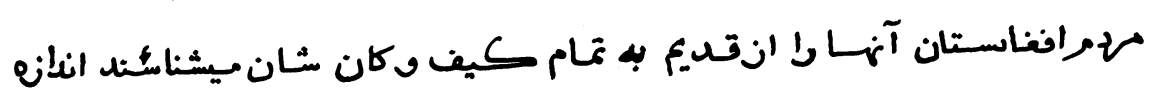

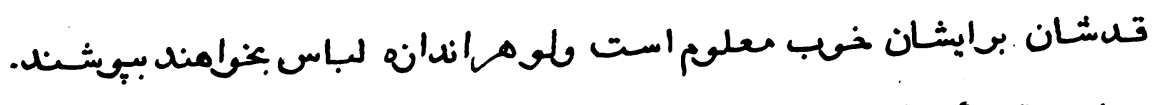

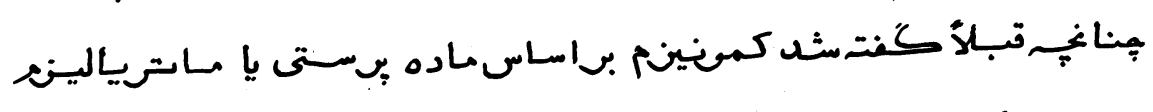

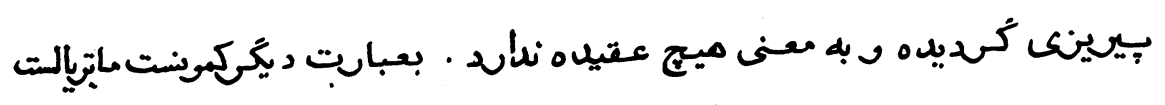

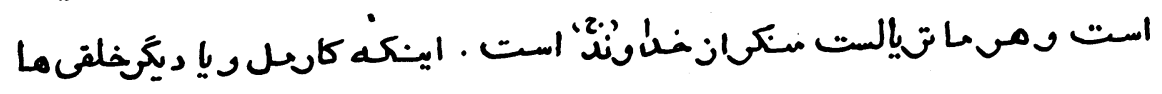

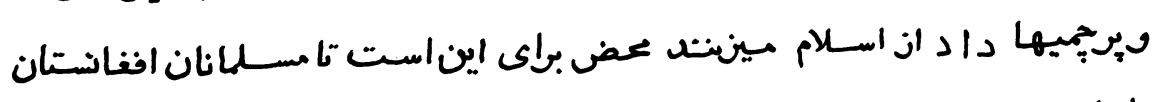
ها بازى دمنل وايسثان را ازيجهاد باز دارند .

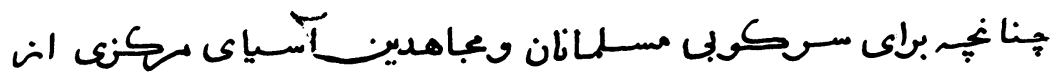

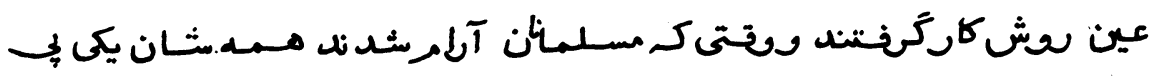


دعىى كرفستل وكسثتند . امـامسـلانان افغاستنان ملامراصلى دميحن

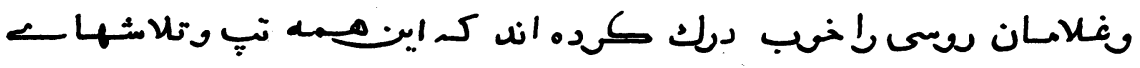

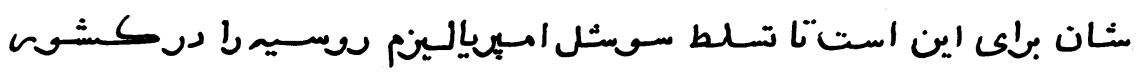

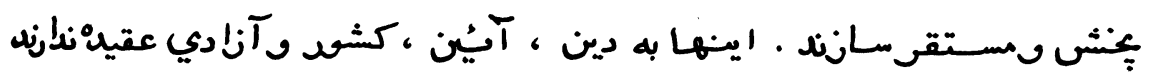

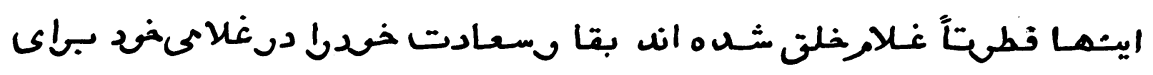

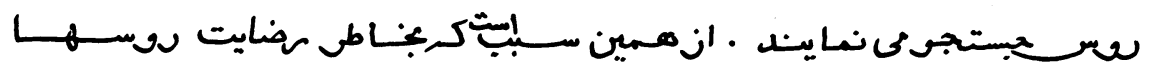

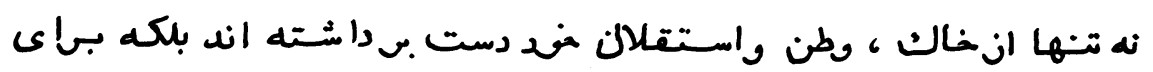

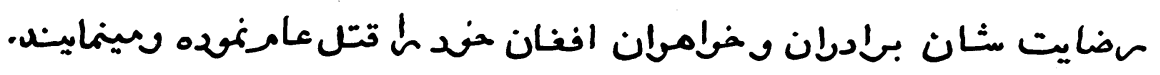

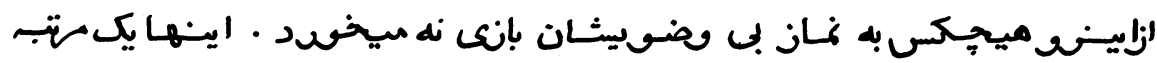

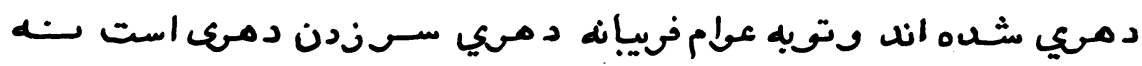
مكومت بكرن دمى :

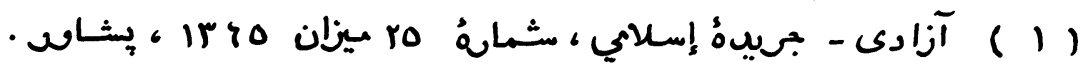
" ايضن (r) - (r)

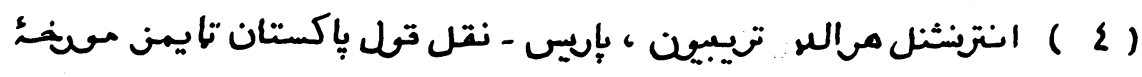

$$
\text { - 19vi إكست }
$$

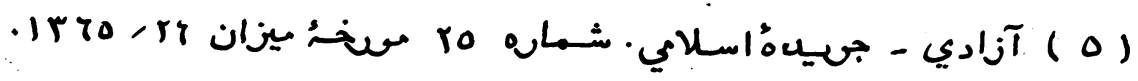




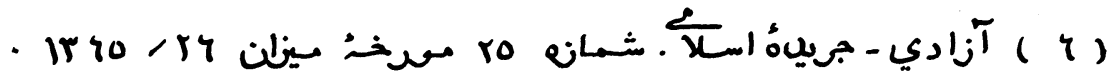

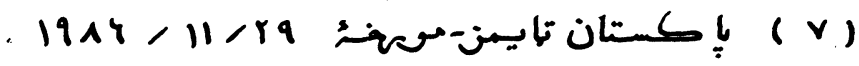

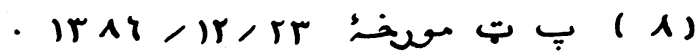

" (9)

ايضاً (1.)

أيضاً (11)

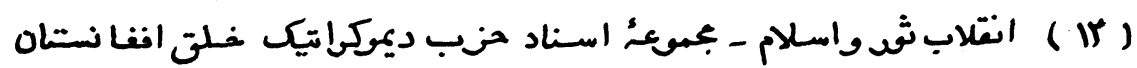

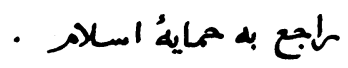

) ايمأ (F)

ir- (1) (1)

Ir $=110)$

$\varphi=(14)$

$r \varepsilon="(I v)$

ro $="(11)$

$r 4=5(19)$

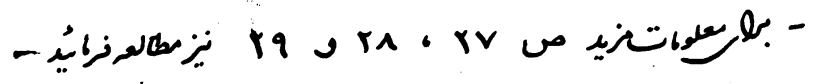


اسندالله غضنف

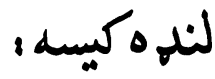

\section{لبجتَكلكديليري}

د يوسف مور نفر آسمان ته هم به كتلو ستري شوي وه ؛ سـول

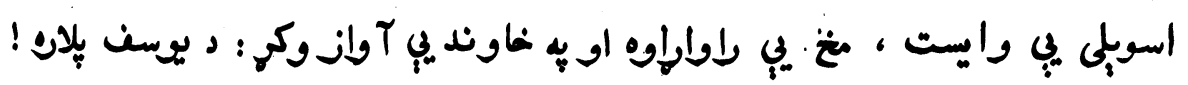

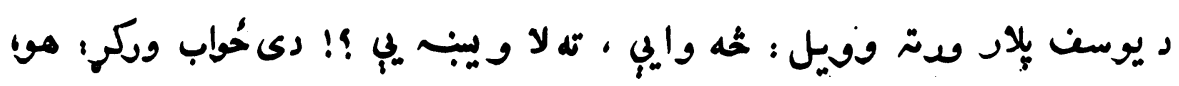

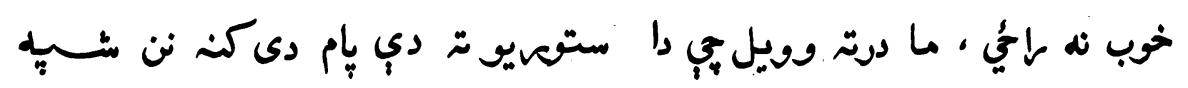

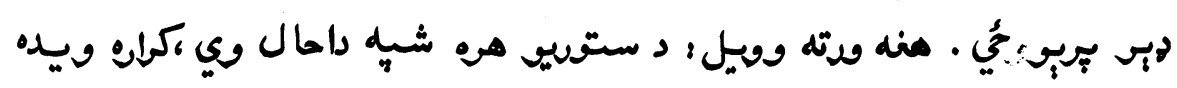

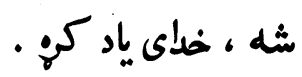

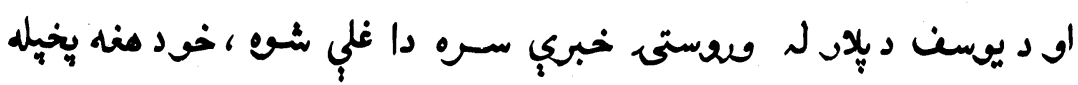

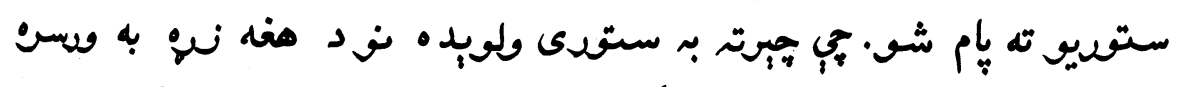

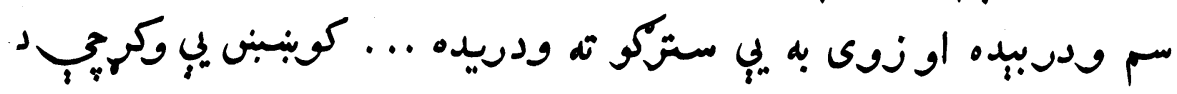

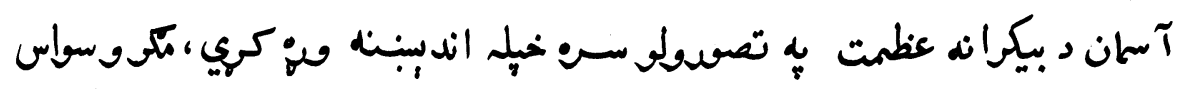

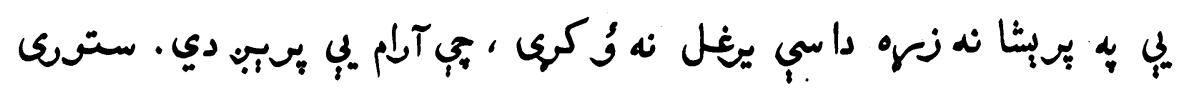

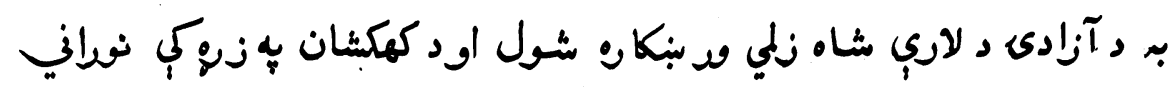

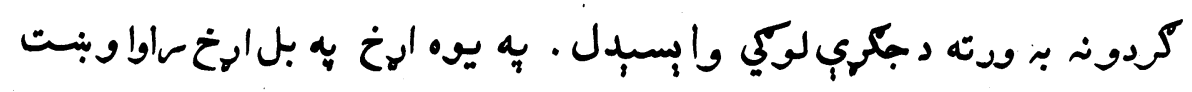




\section{قلم}

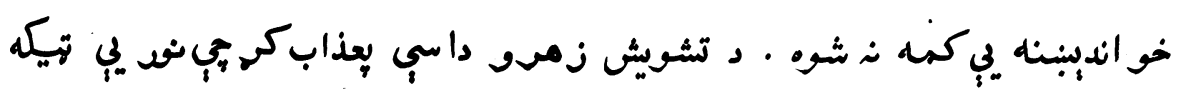

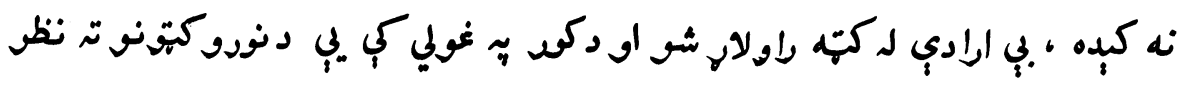

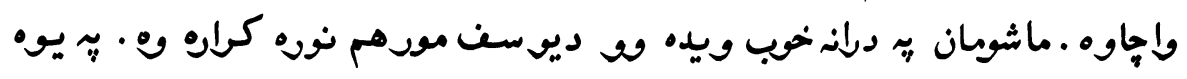

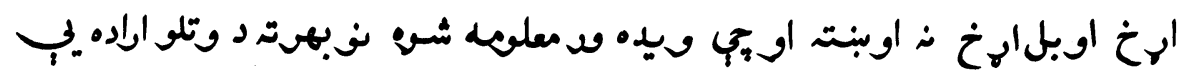

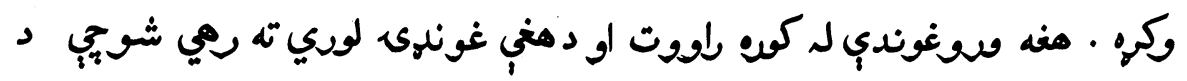

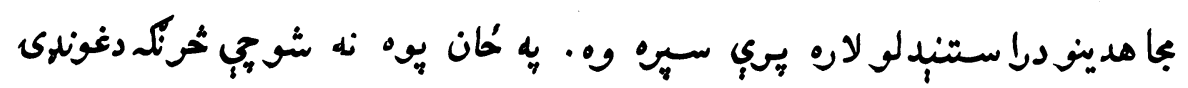

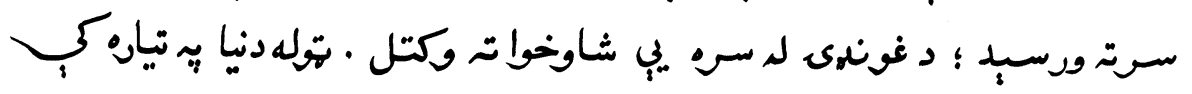

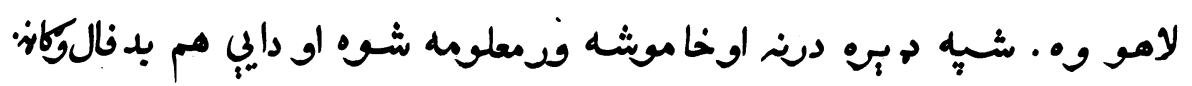

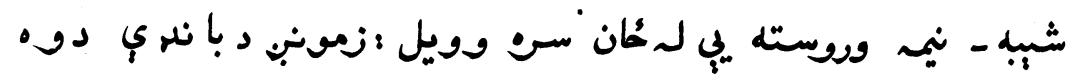

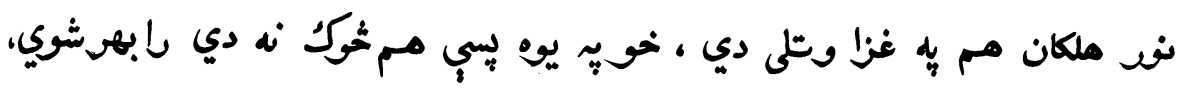

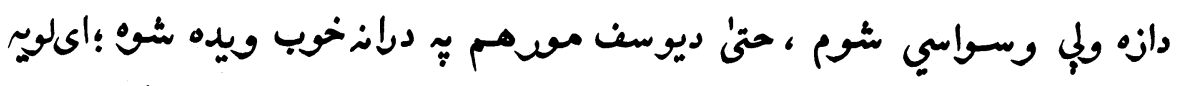

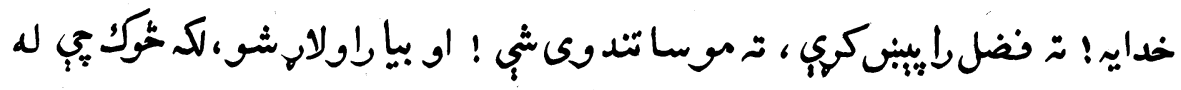

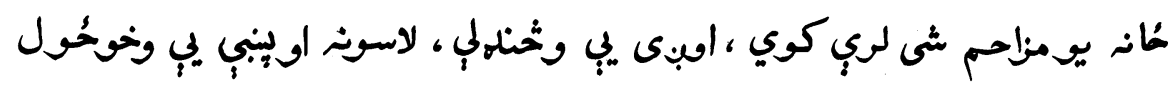

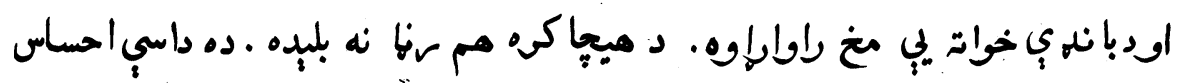

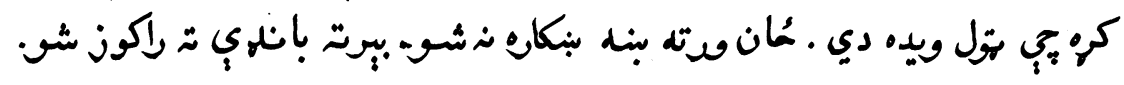

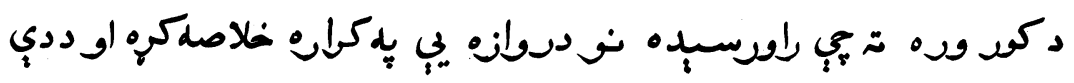

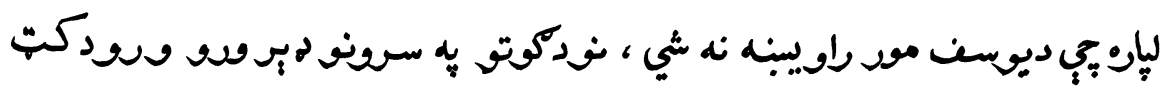

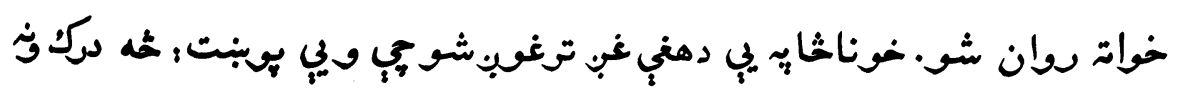

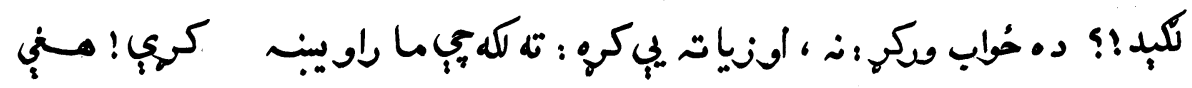




10

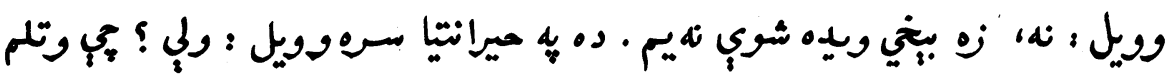

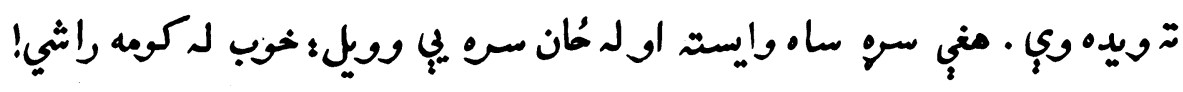

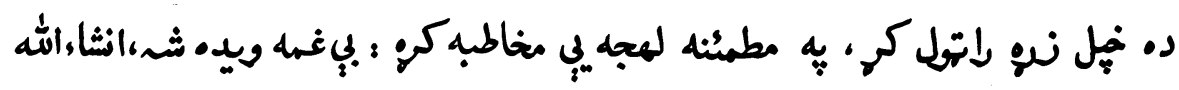

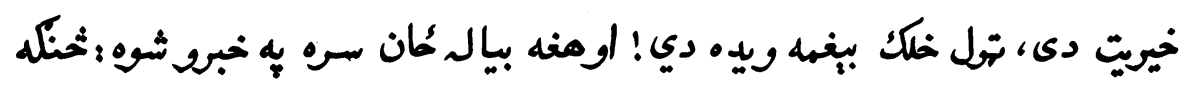

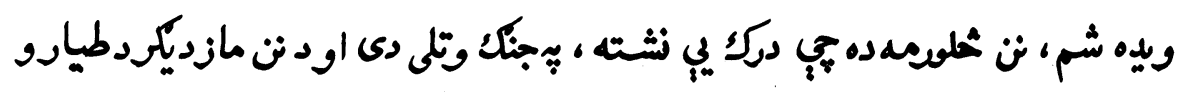

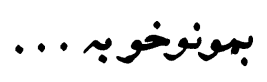

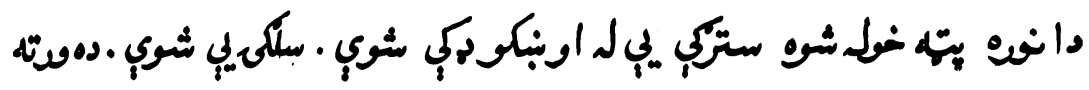

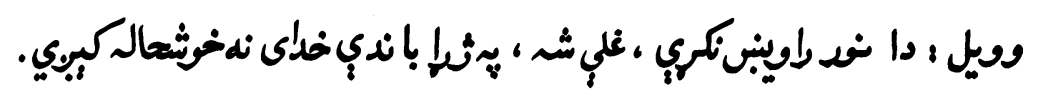

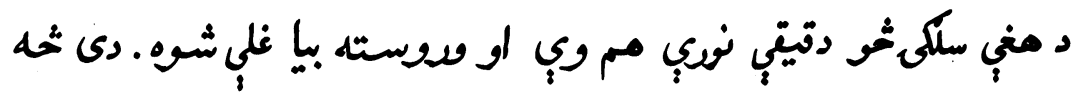

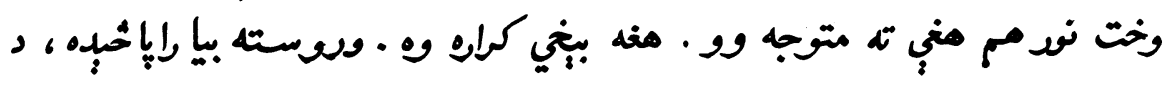

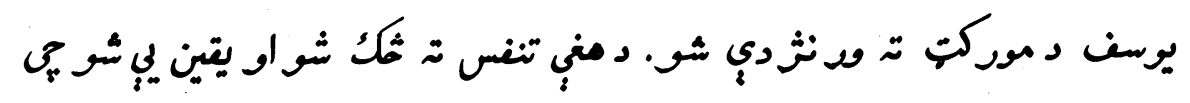
منه خرب صئ ده.

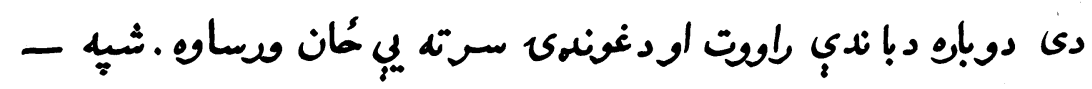

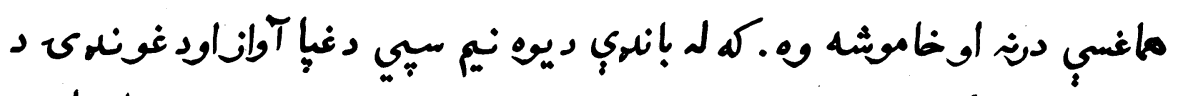

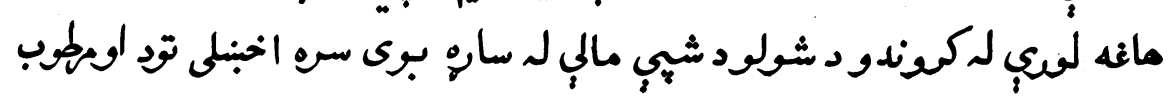

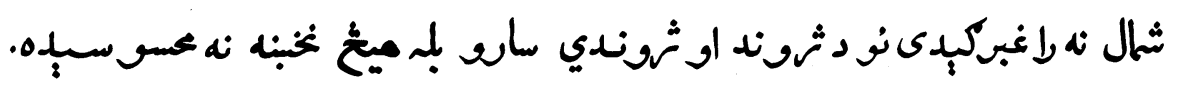

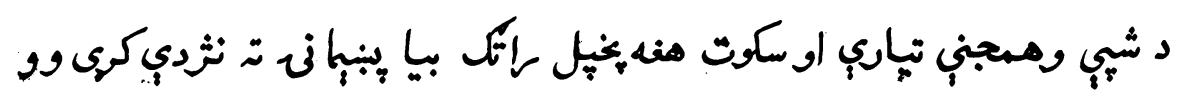

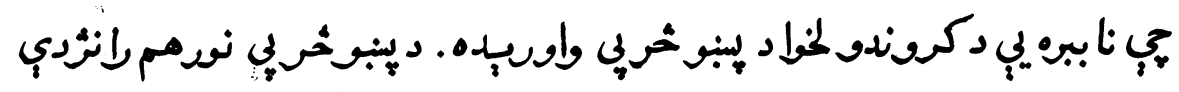

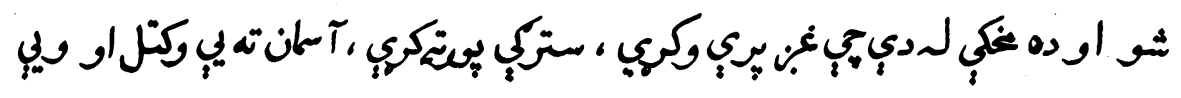




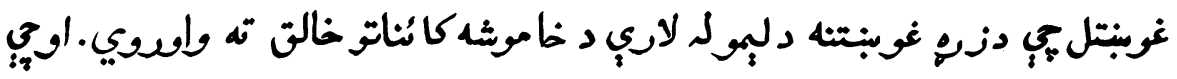

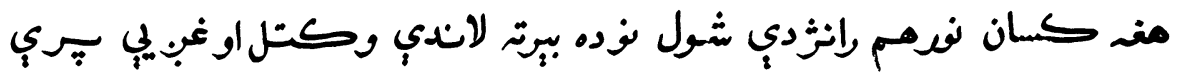

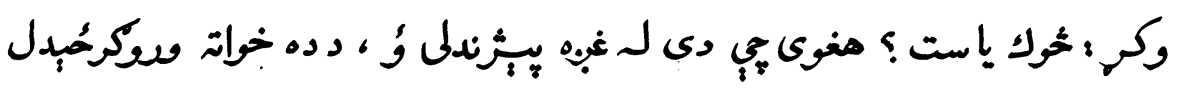

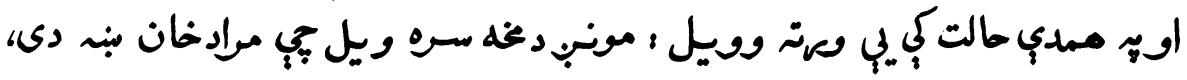

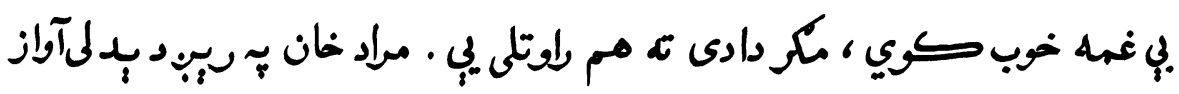

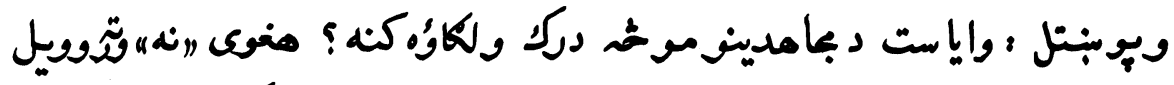

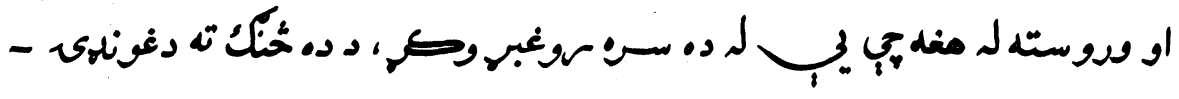

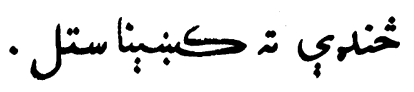

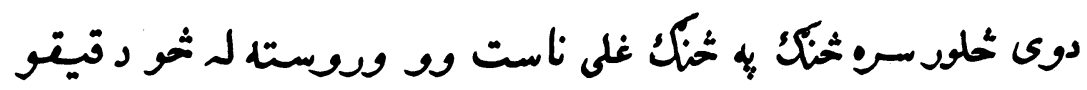

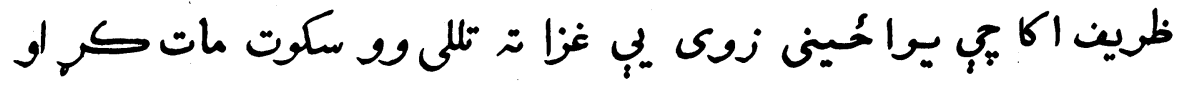

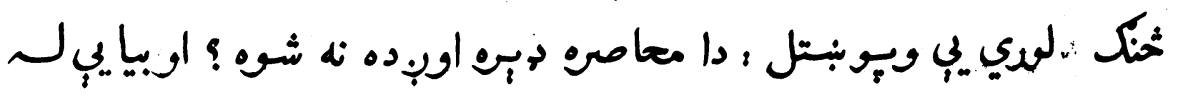

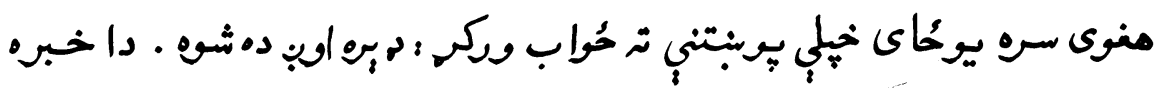

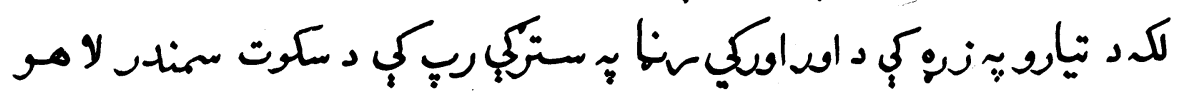

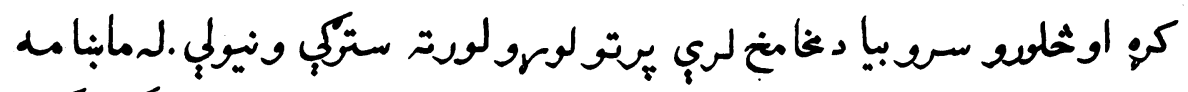

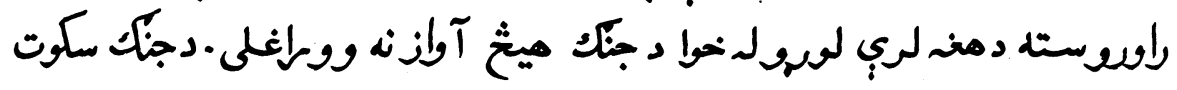

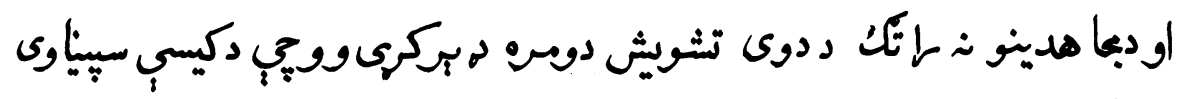

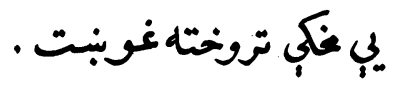

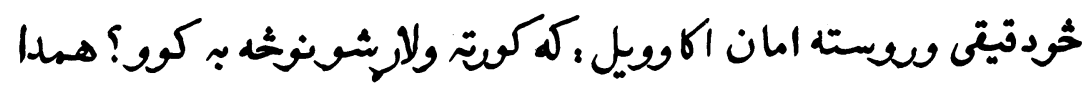

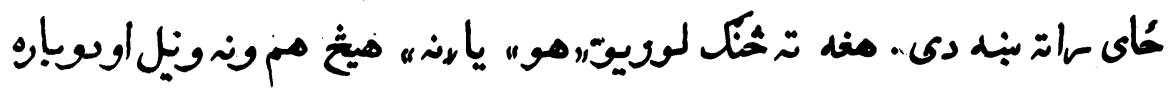




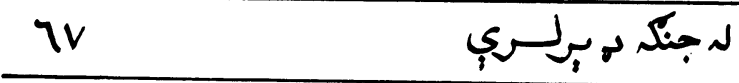

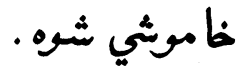

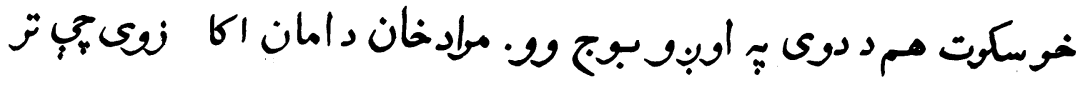

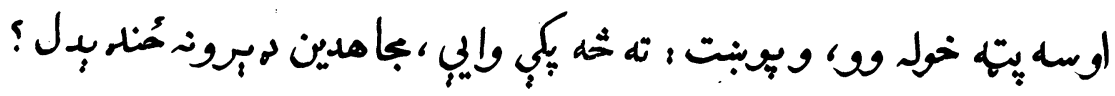

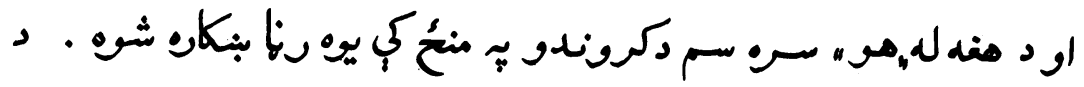

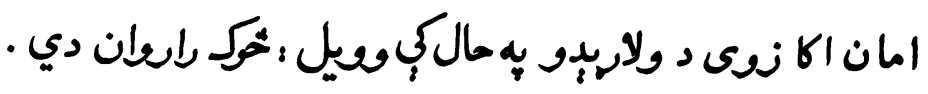

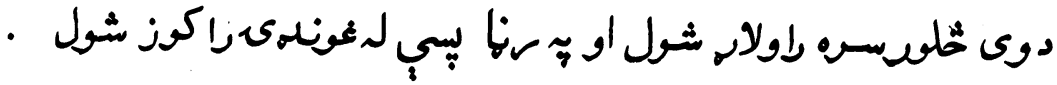

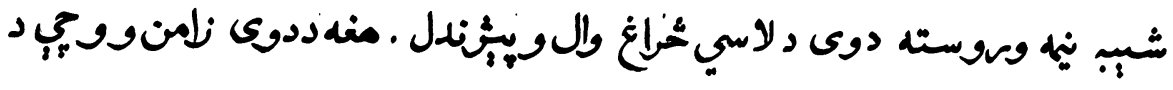

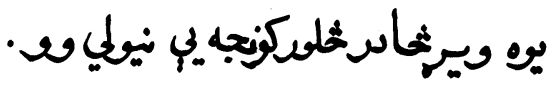

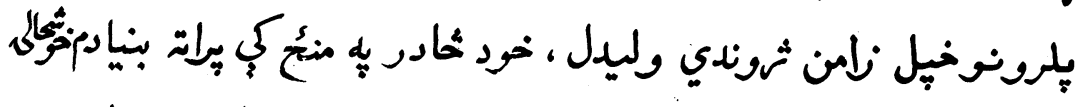

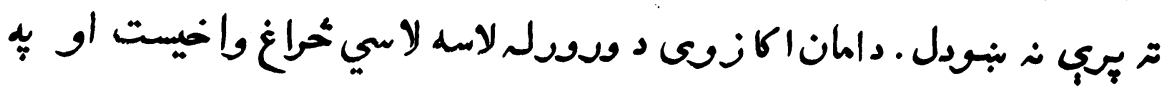

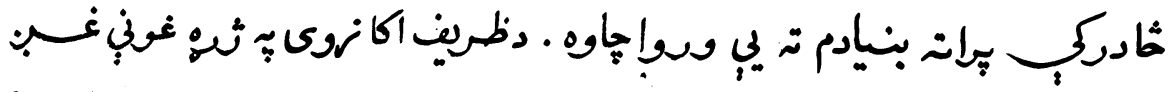

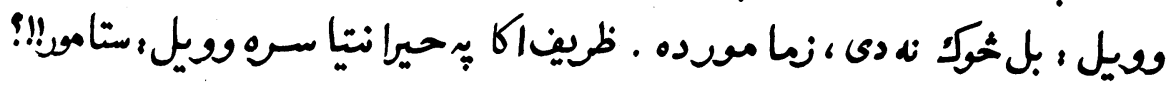

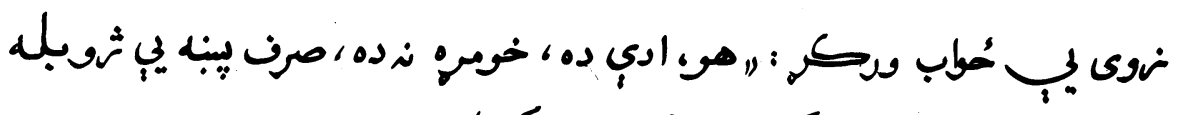

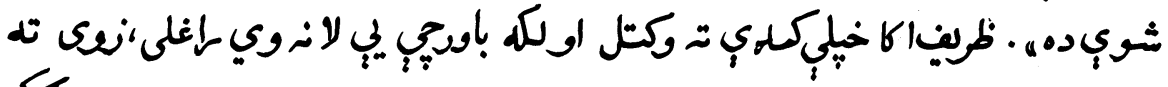

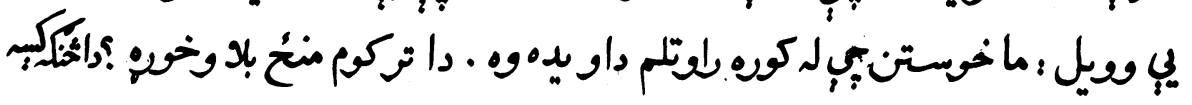

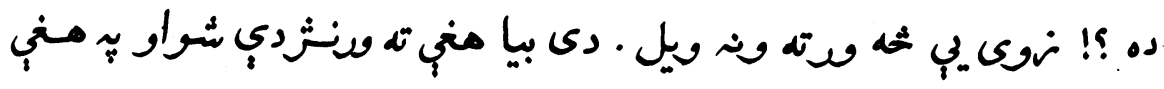

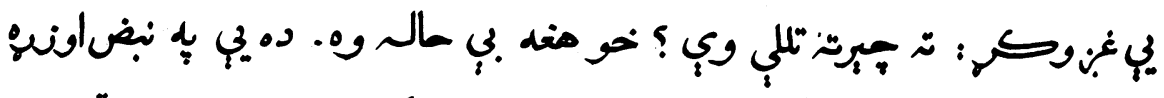

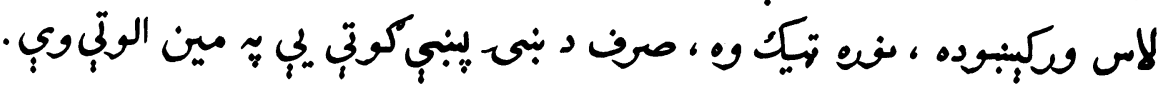

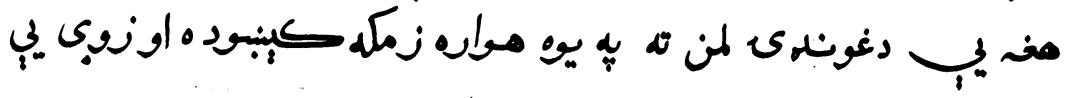




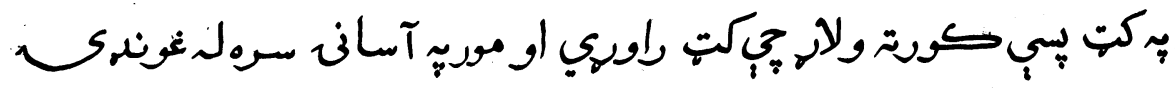

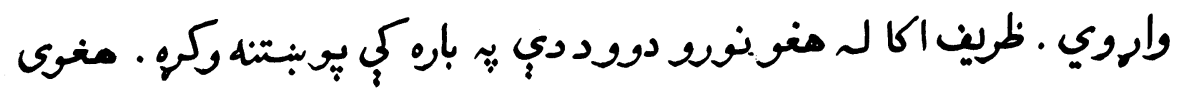

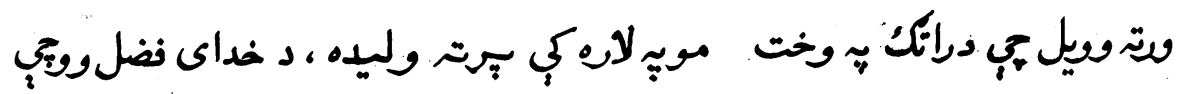

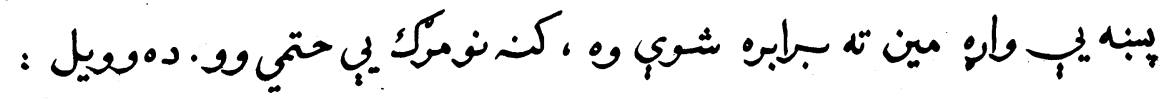

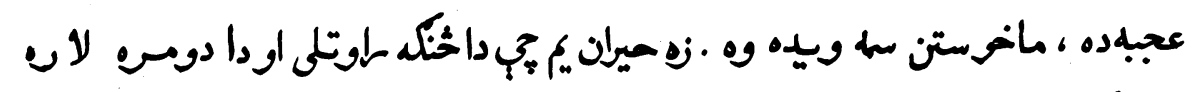

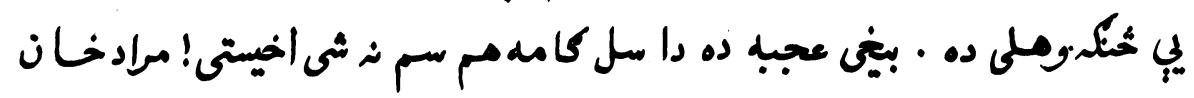

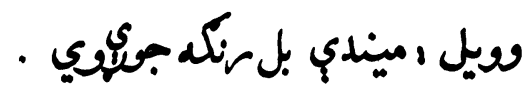

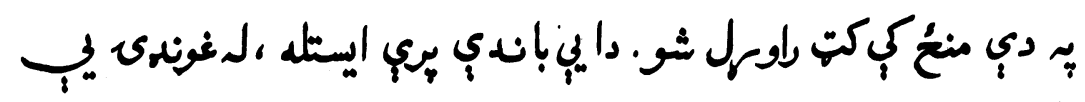

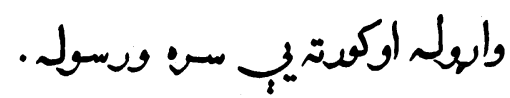

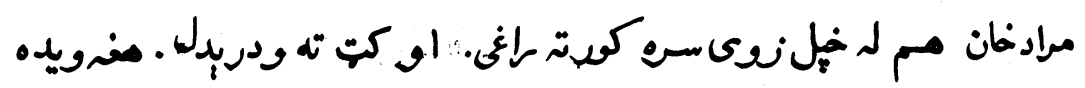

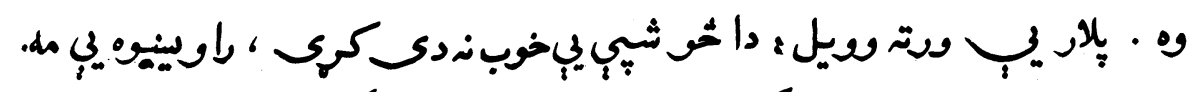

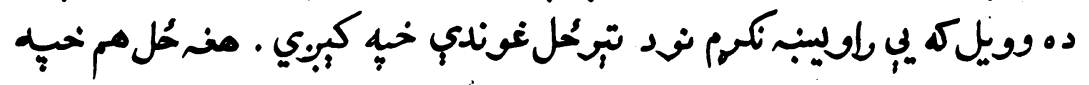

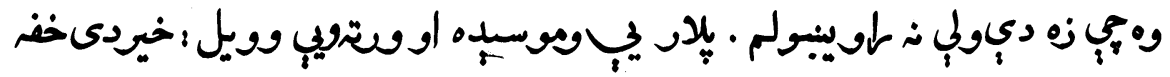
ديثي !

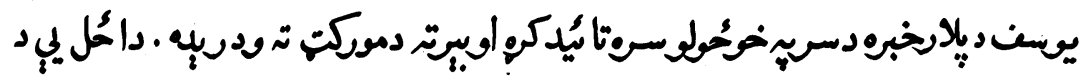

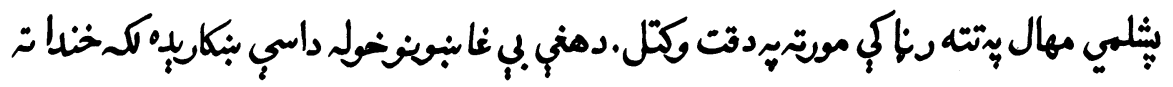

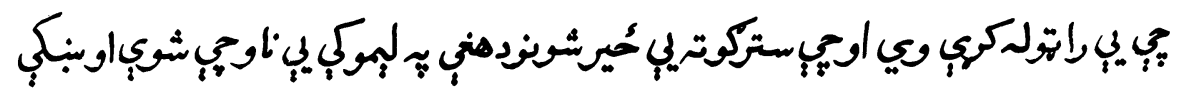

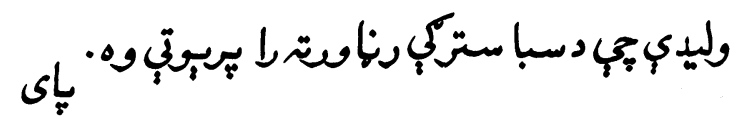




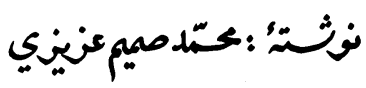

ككُ راستانكوتا.

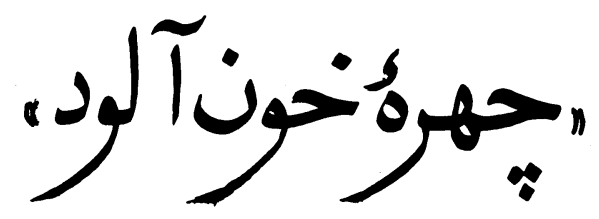

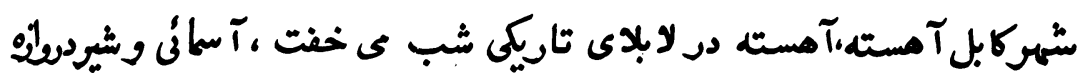

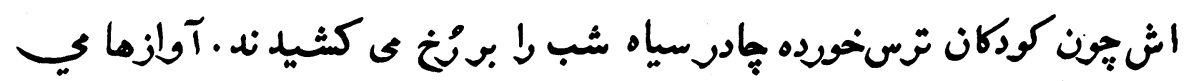

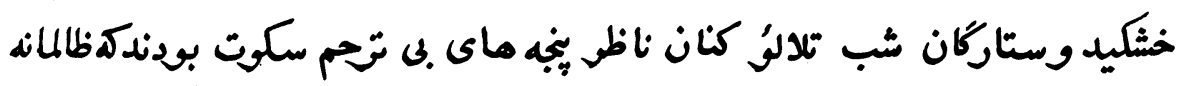

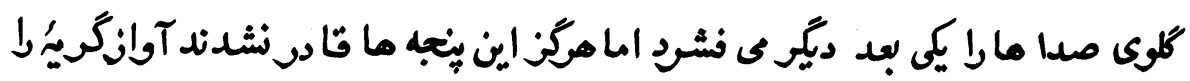

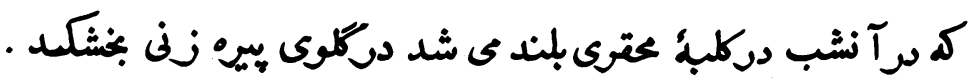

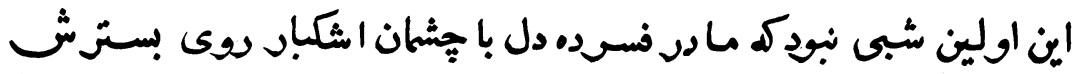

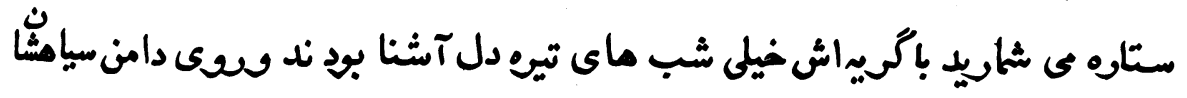

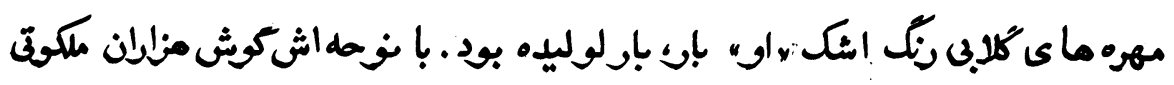

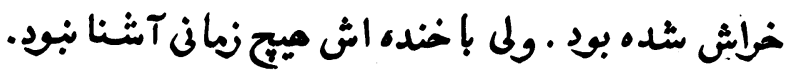

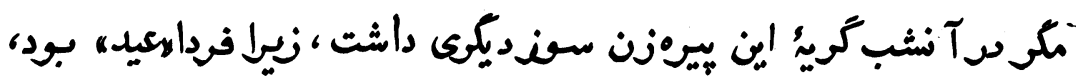

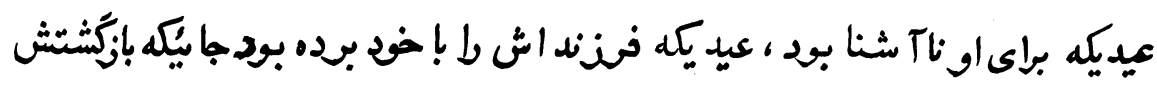




ve v.

\section{نامكن بود (....}

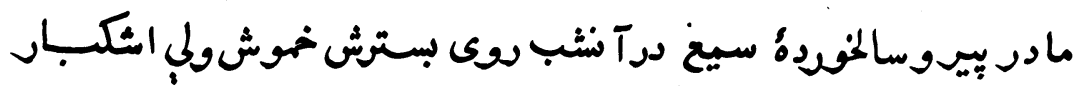

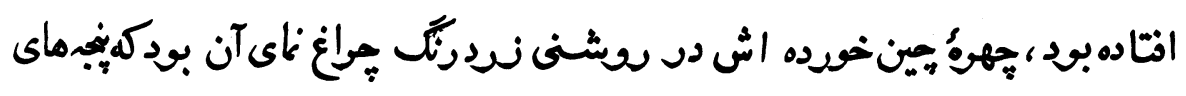
نا ملايم دوزكارمويكى راروى صوتش با قصاوت تام نقشيده است.

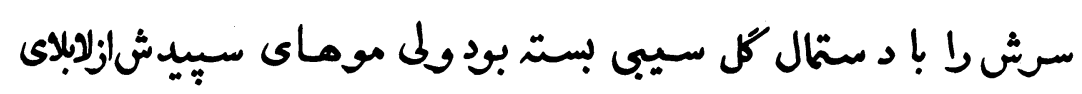
آن نقل جالنى اش لإتيميم ميكتد .

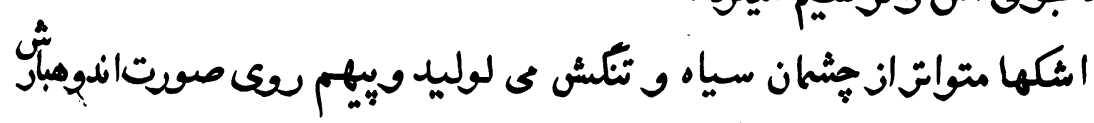

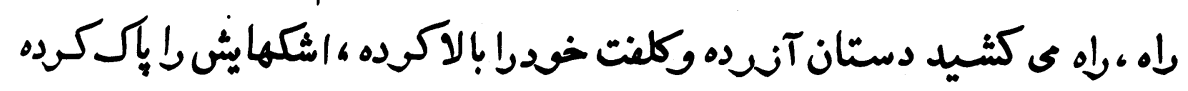
كمت :

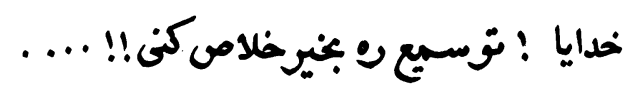

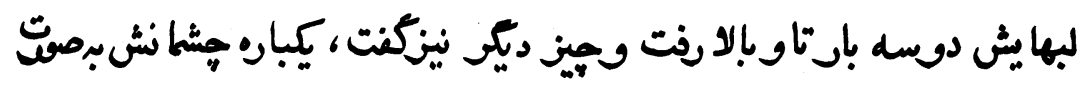

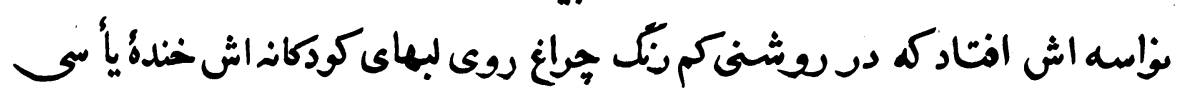

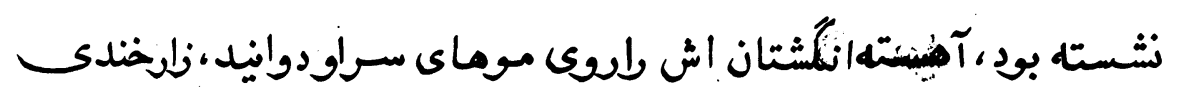

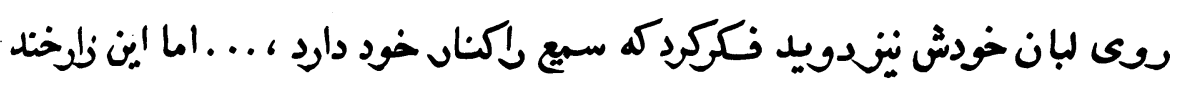

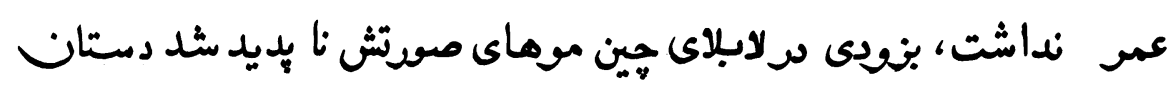

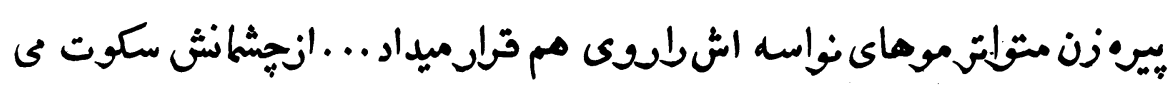

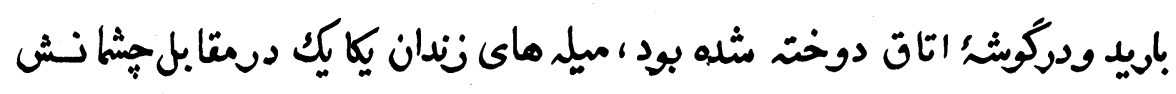

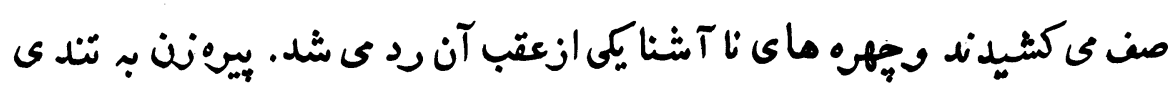

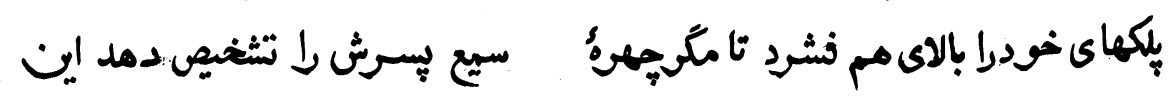




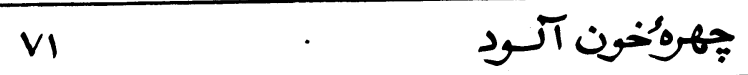

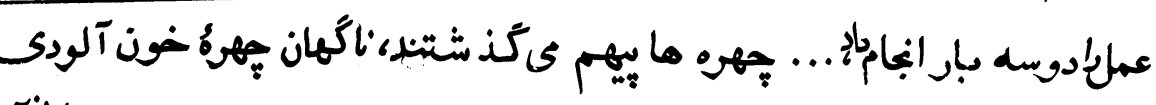

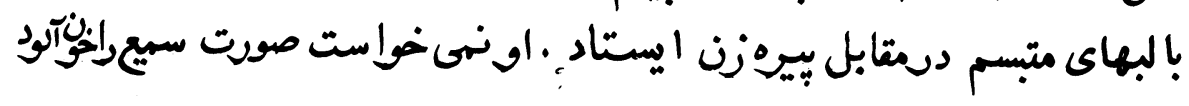

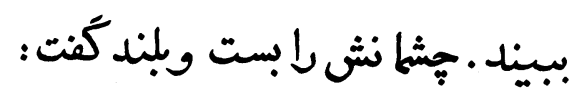

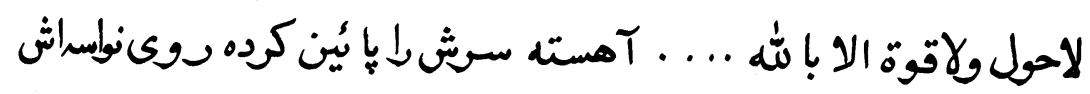

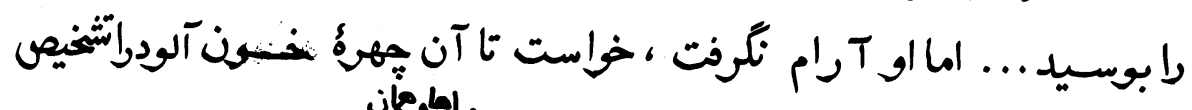

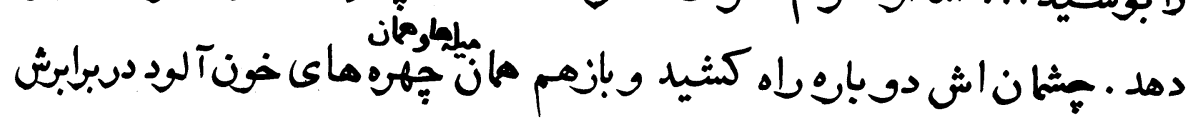

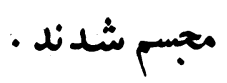

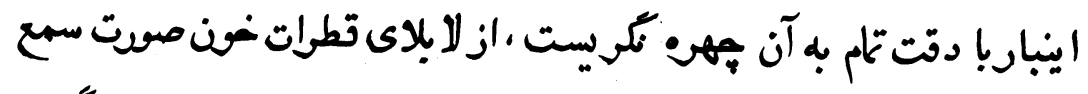

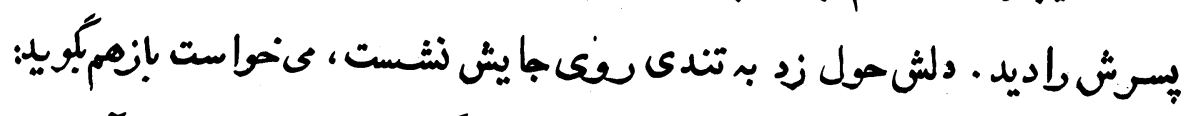

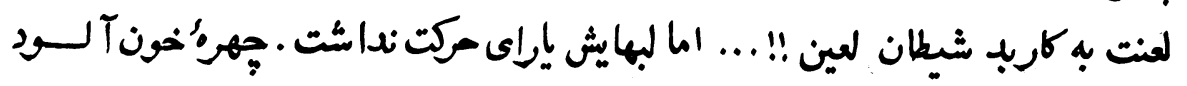

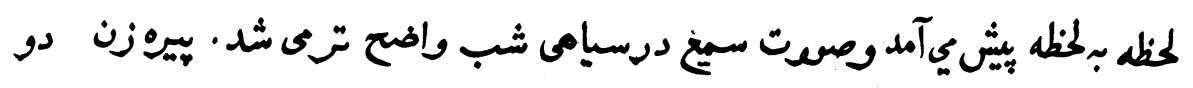

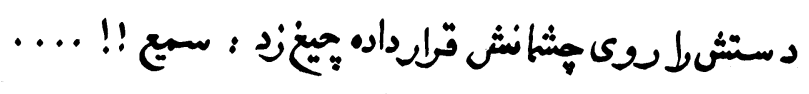

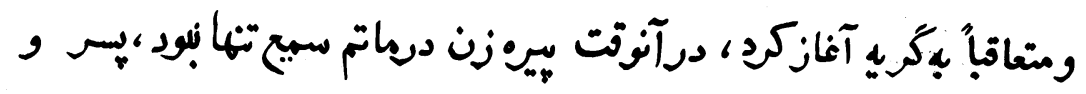

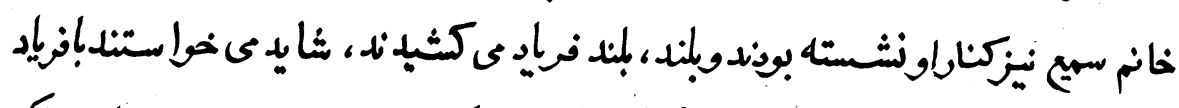

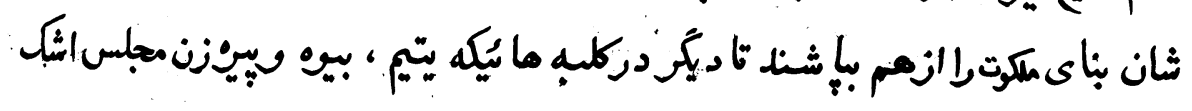

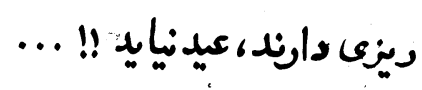

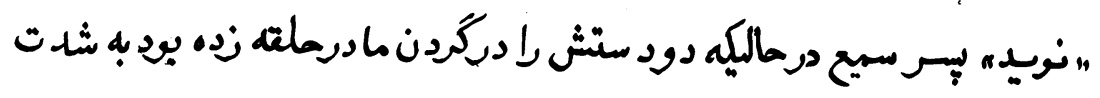

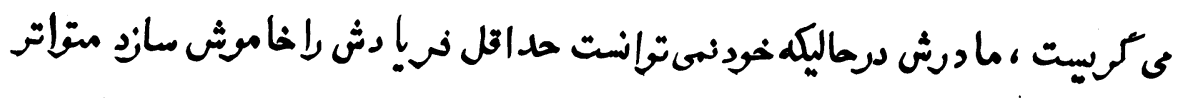

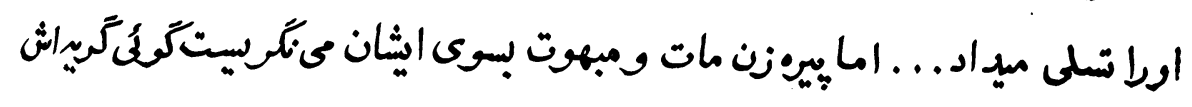




\section{"6}

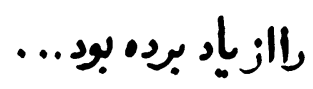

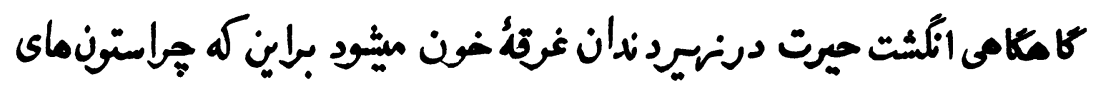

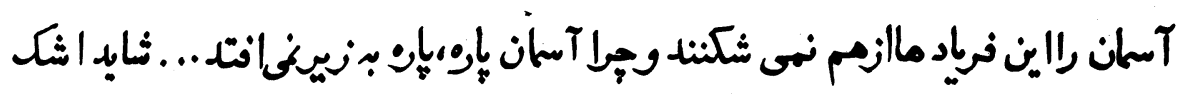

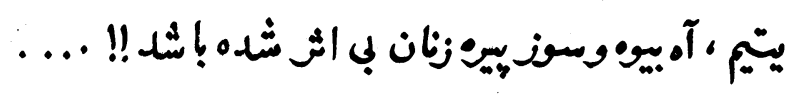

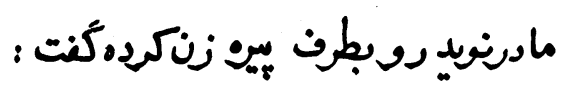

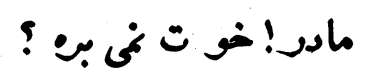

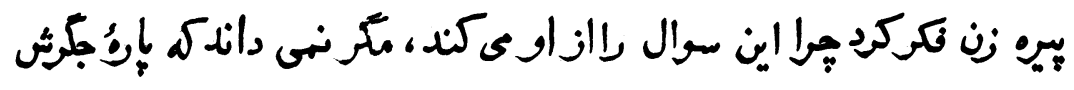

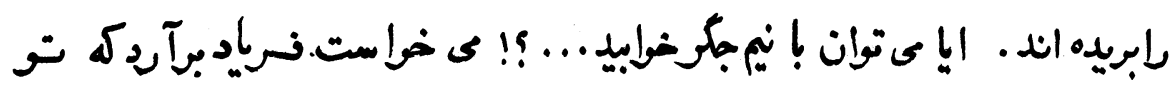

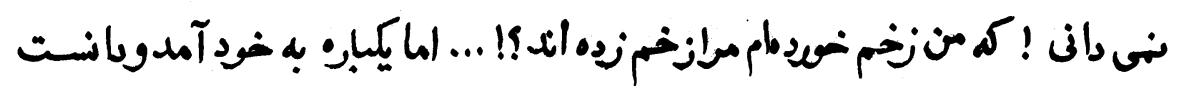

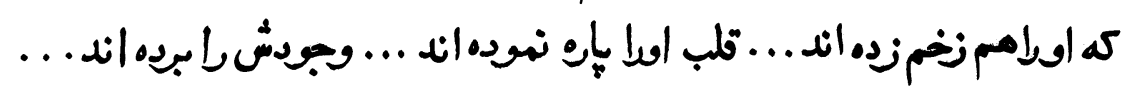

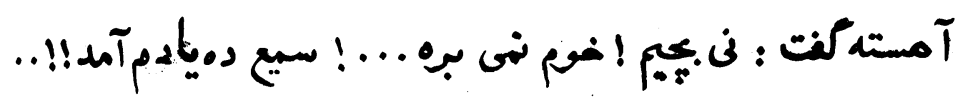

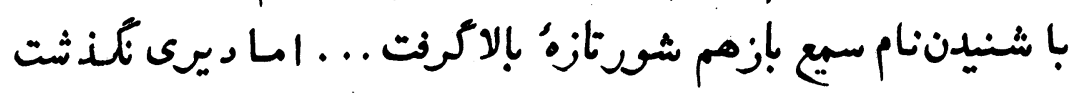

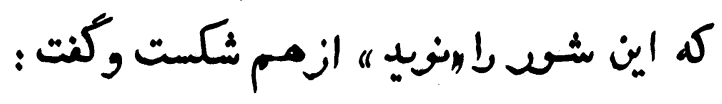

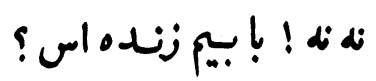

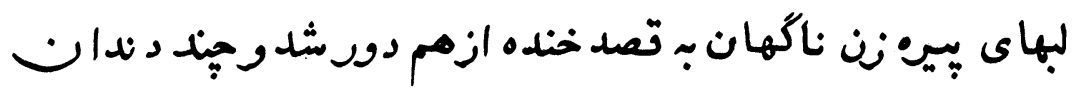

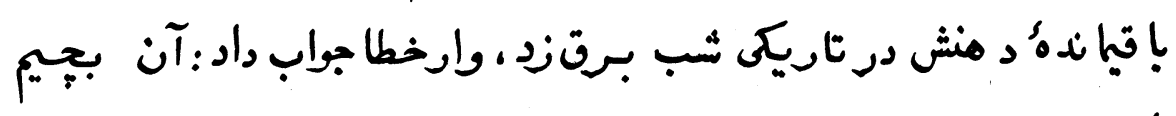

$$
\text { بيت زنده اس !.. }
$$

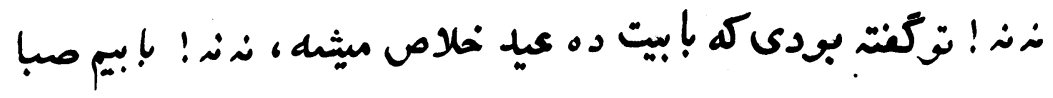




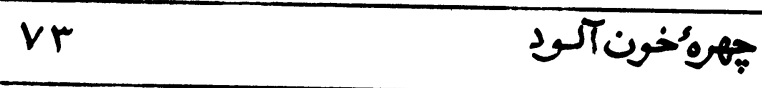

خلاص منّه ?

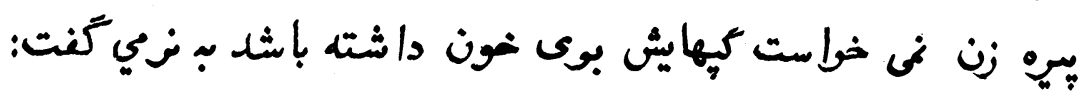

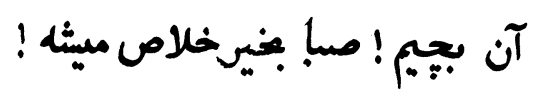

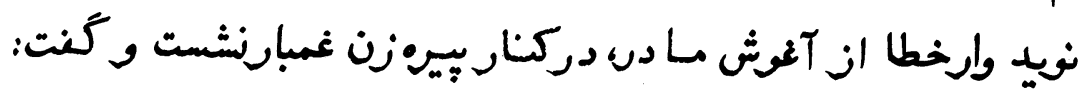

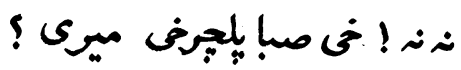

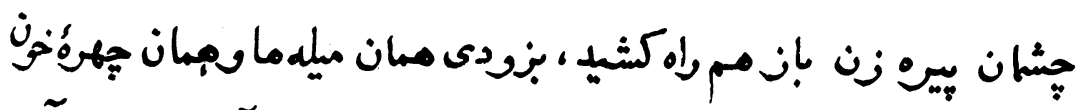

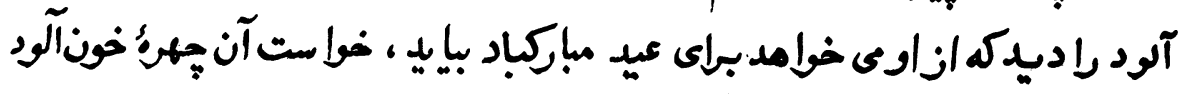

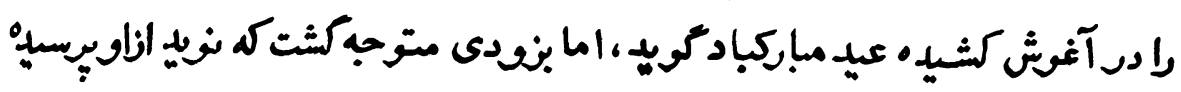

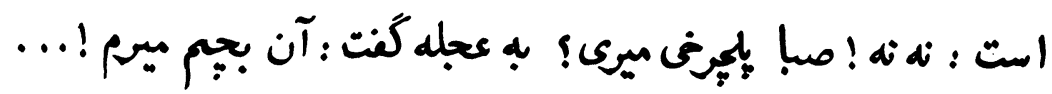

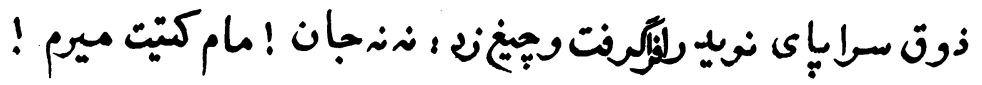

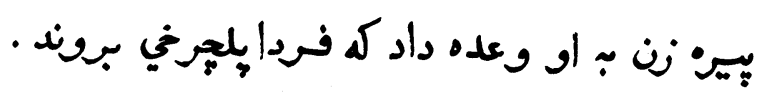

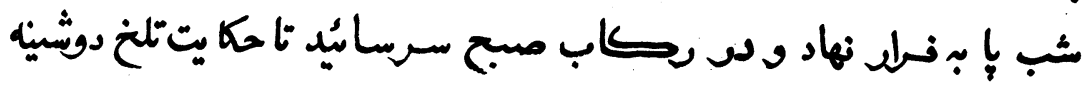

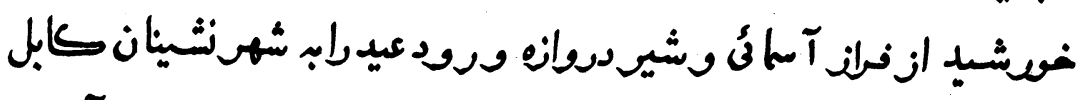

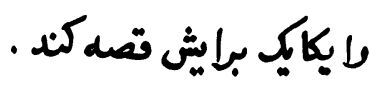

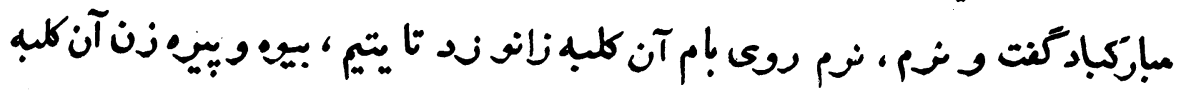

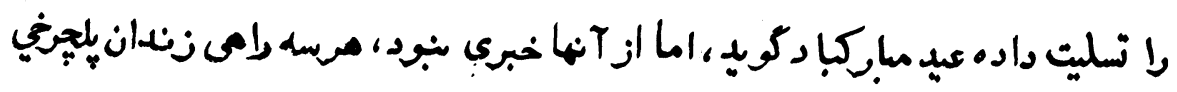
شده بودند.

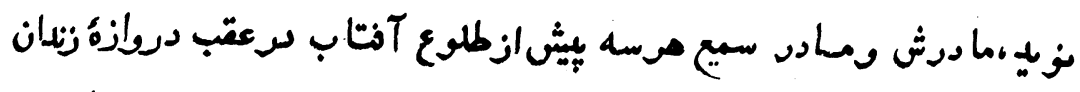

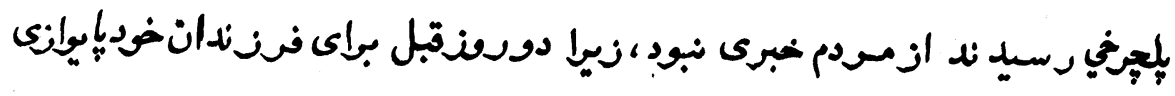




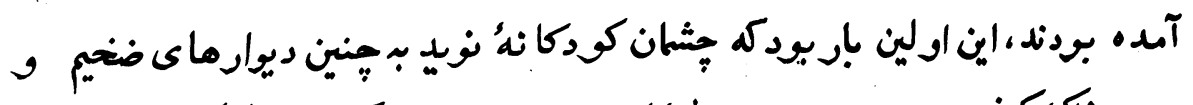

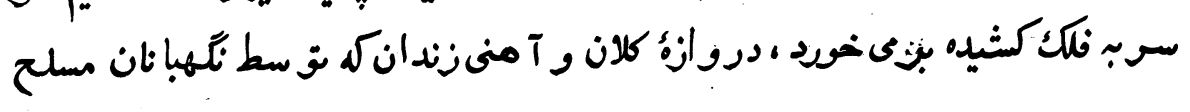

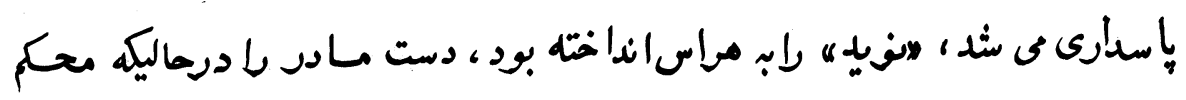
دردستش داشت برسيد:

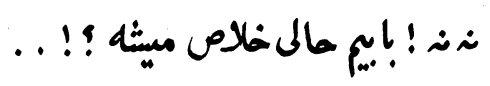

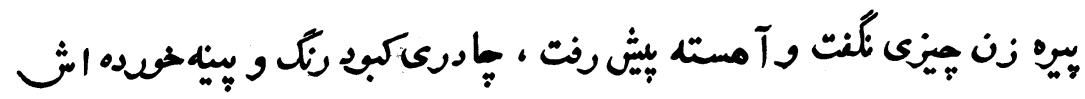

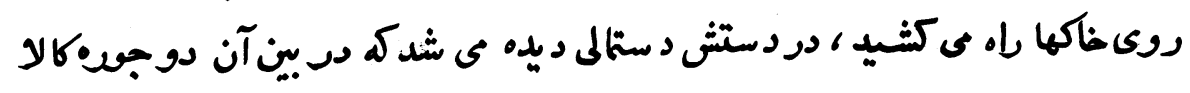

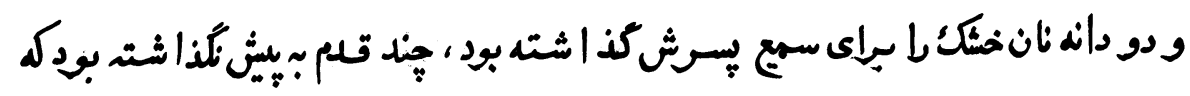
عسكرؤظف صدازد :

نه نه إزكجا آمدى ؟ خيريت خواس ؛ ده ایى رغذعيد آم ازدست شما Tرام

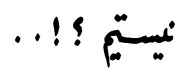

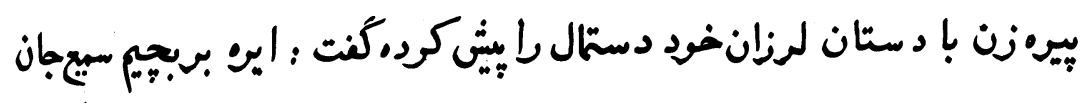
Tورديץ !

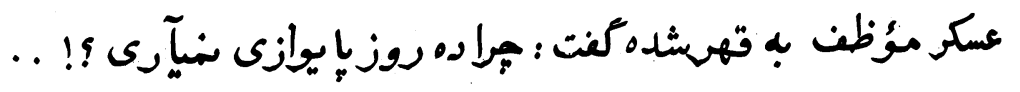

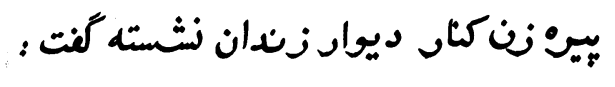

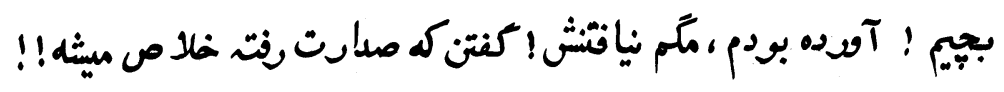

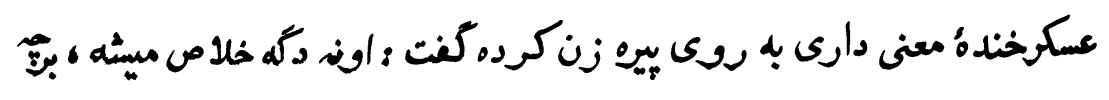

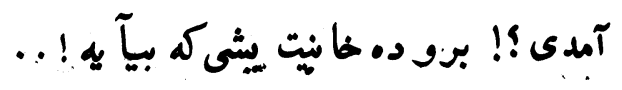

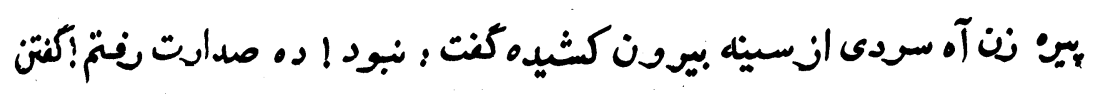




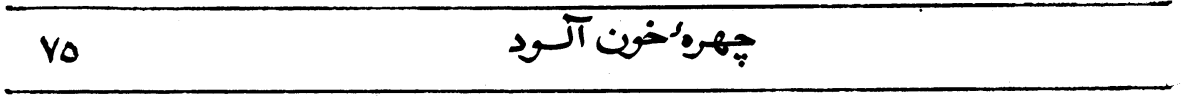

\section{اينجبنيس بلجبرثى بور!}

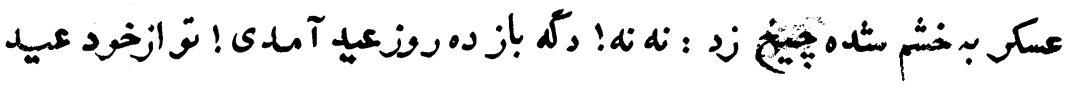

ندارى؟!

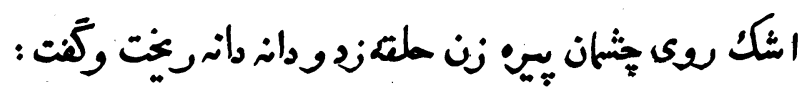

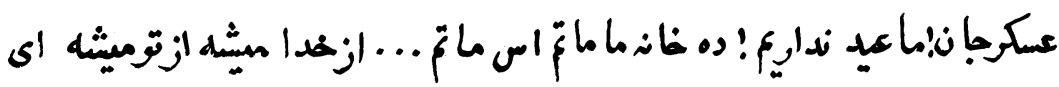

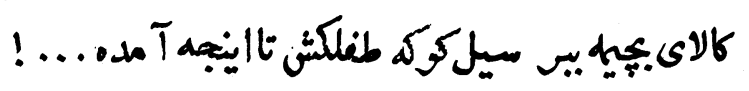

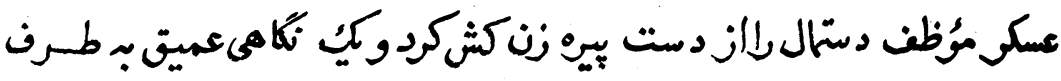

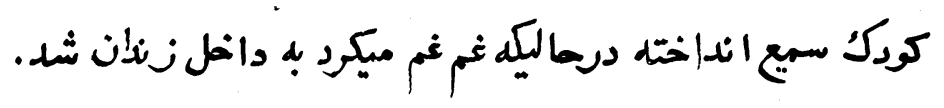

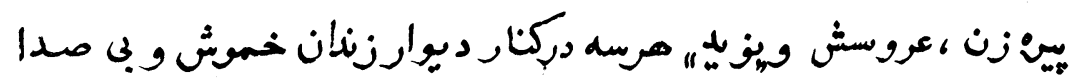

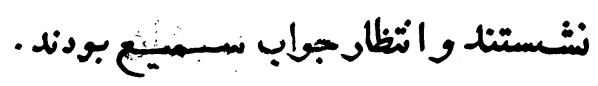

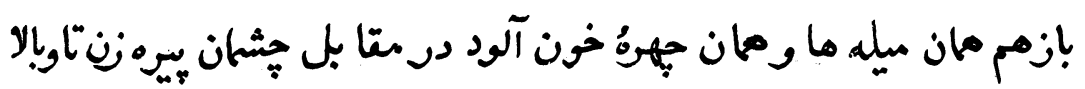

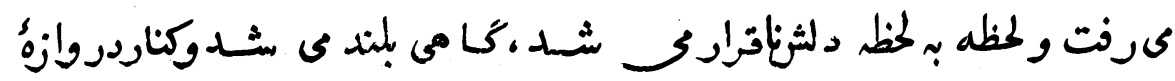

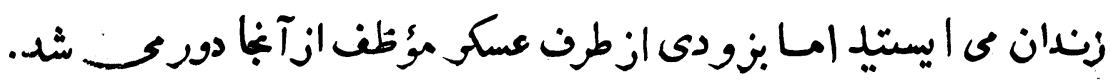

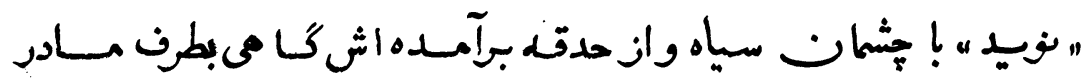

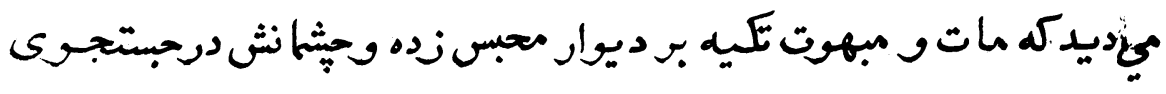

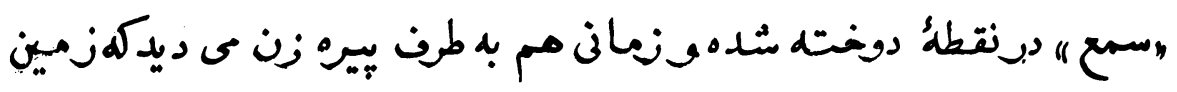

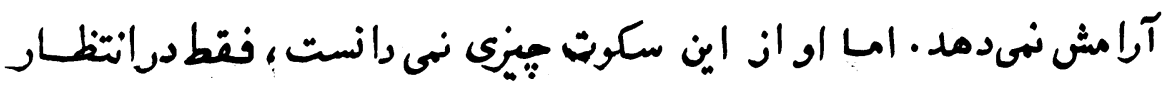

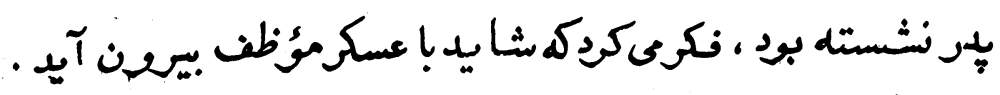

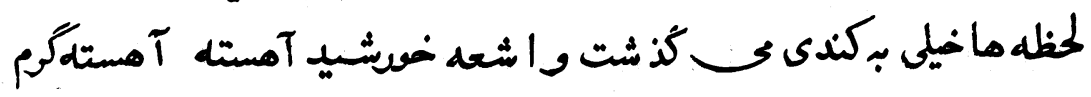




\section{قلم}

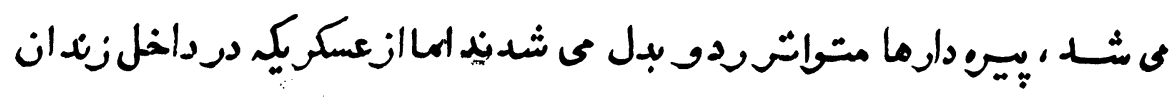
رتت بوق اثثى نبود.

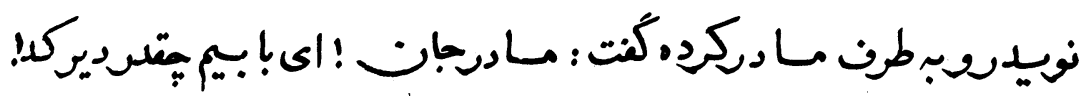

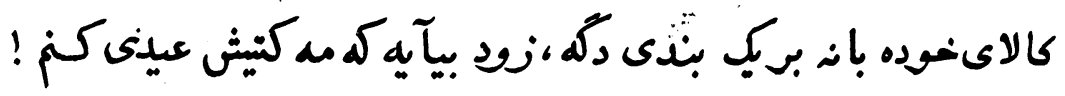

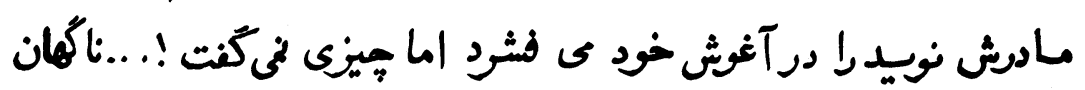

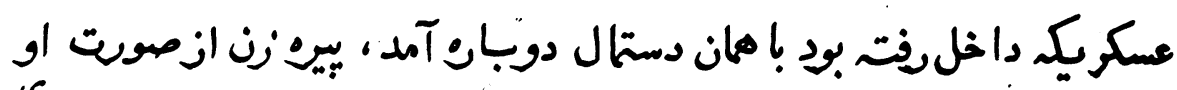

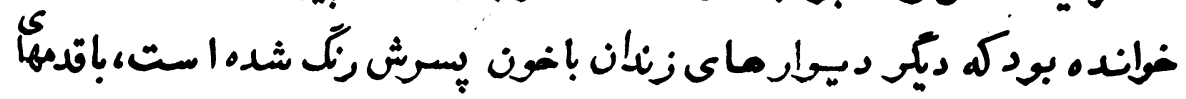

$$
\begin{aligned}
& \text { لرزان نسرديك رفتهكت : } \\
& \text { عسكرجان ؛ نبود ؟! . . . }
\end{aligned}
$$

عسكرموُظف ابرومايشرا بالا انداختد كفت : نى نه نه ! ده مرسمبلاكك

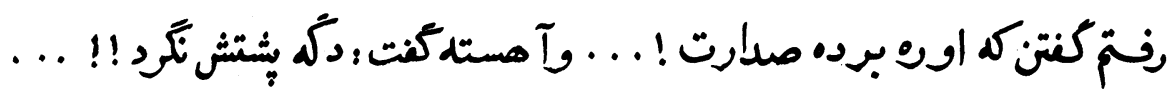

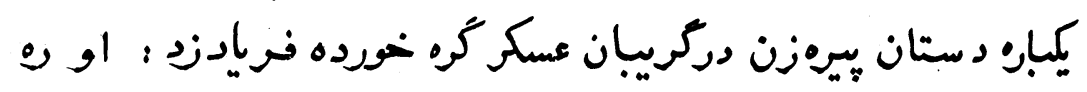

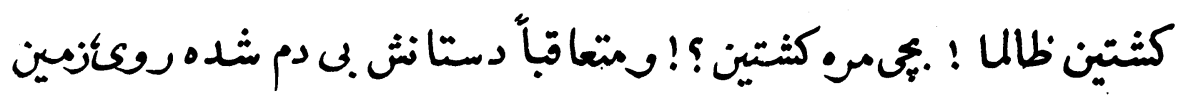
انتاد.

نويد خود را درآغوثَ مـادرانداخته لبند صدازد : ب بيهكثــن

مـادر!

امامادرش مهانكون بـ ديوارزندان تكيهزده بود ميز آوازي از او

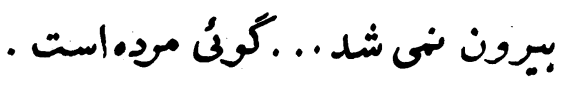

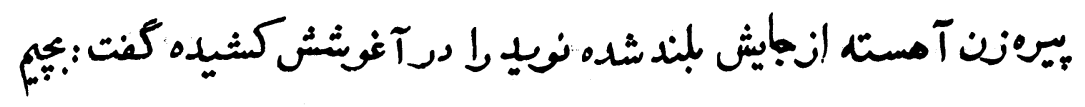




vV 2

عيدات مبإرك .

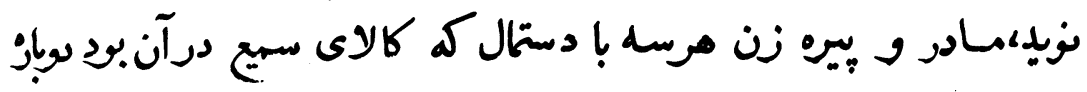

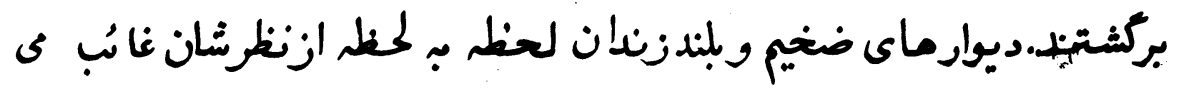

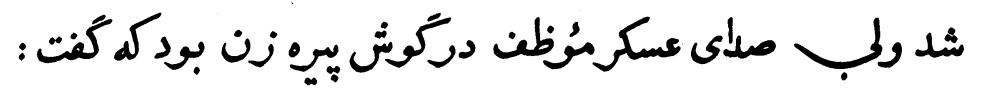
ن ن إ دكم يشتش نكر. 
وليحمدولي امخكزى

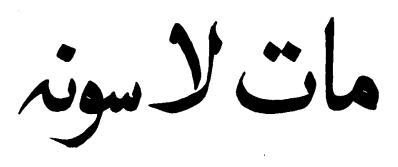

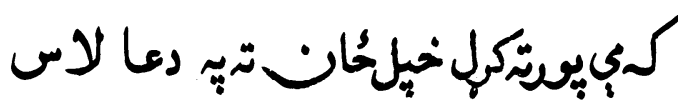

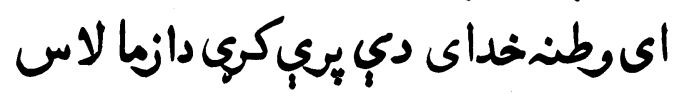

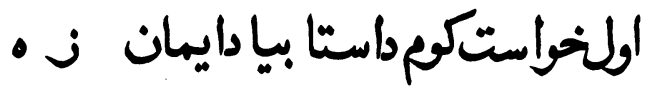

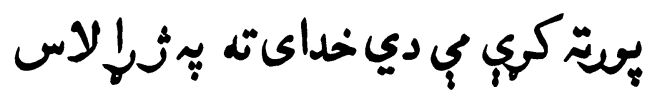

ستاير ميندكي تزخيلمال وسر تبريي

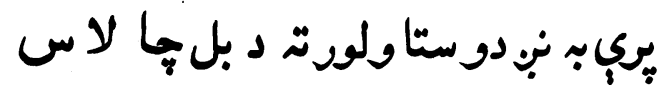

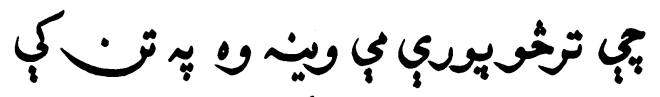

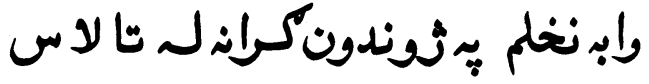

دا نسان ود ديوان مكك دئُبي خسرقه

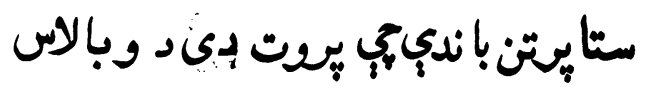

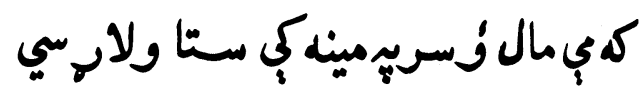

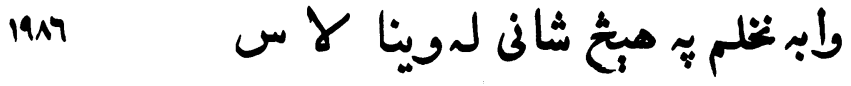




v9

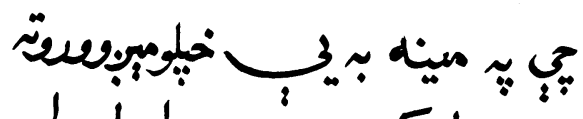

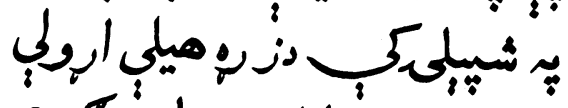

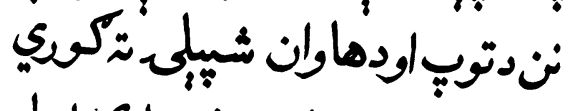

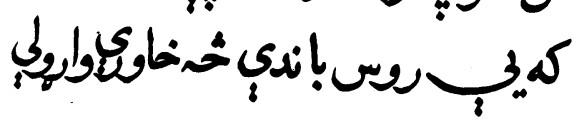

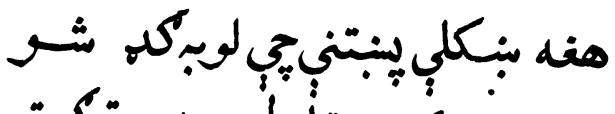

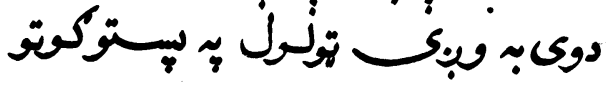

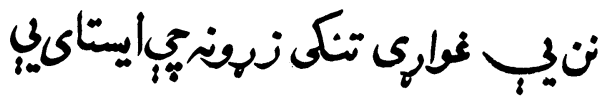

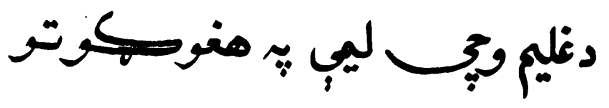

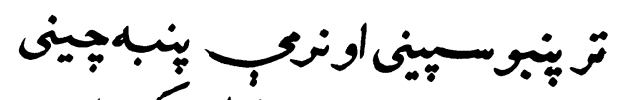

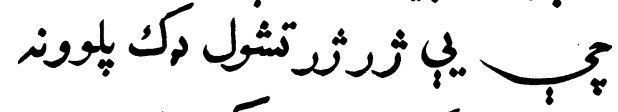

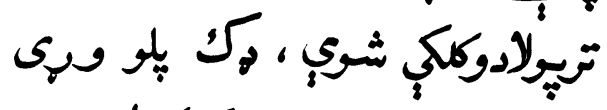

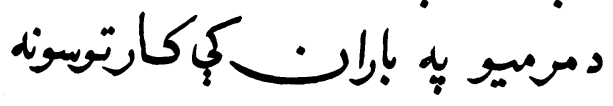

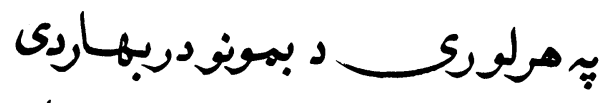

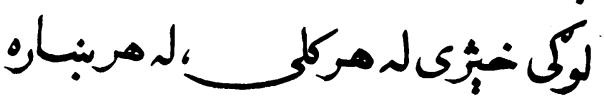

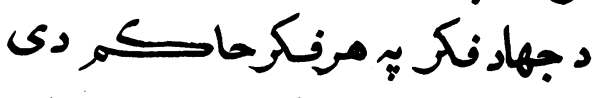
نوخبرن دكس لوكسب اولركـار. 


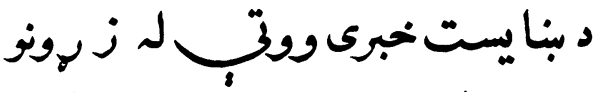

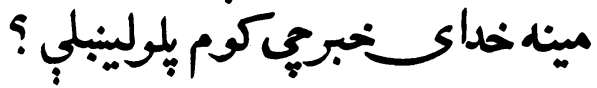

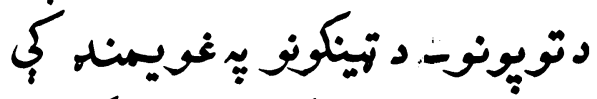

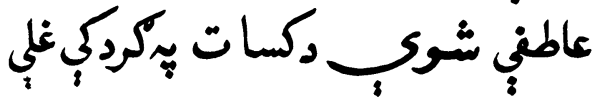

تي مئح لإيادونغ نصن ت راشي

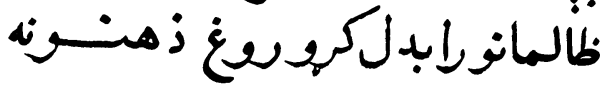

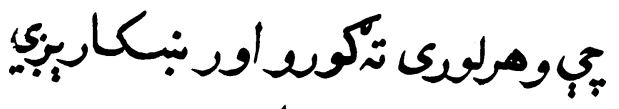

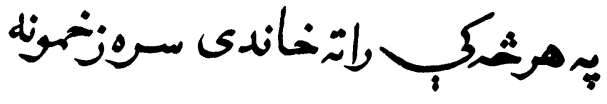

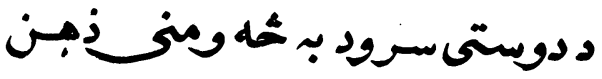

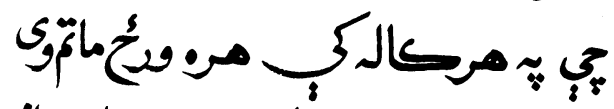

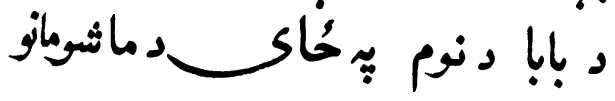

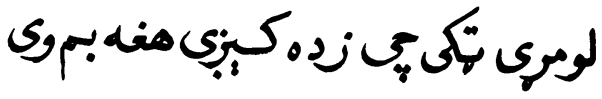




\section{دويتراني}

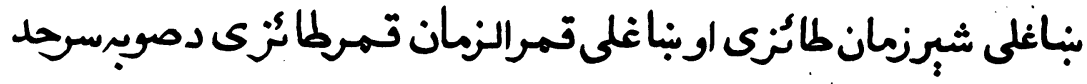

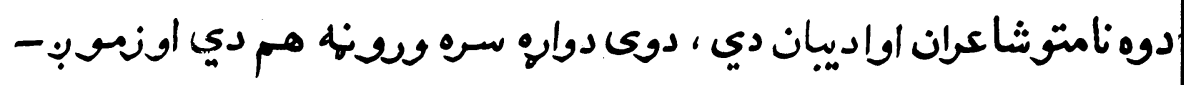

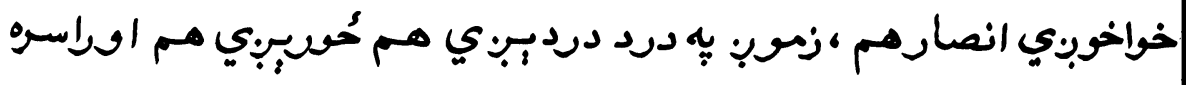

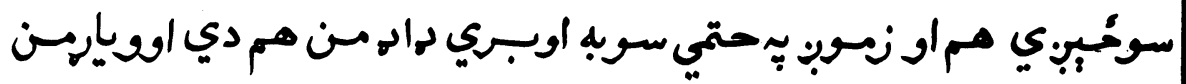

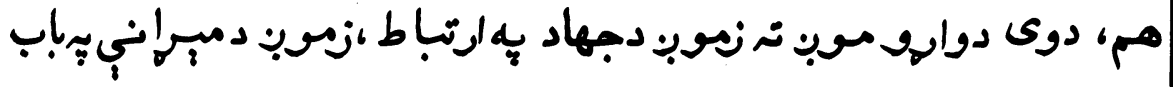

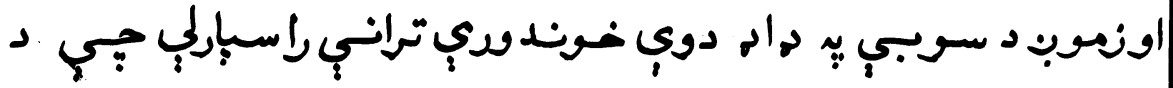

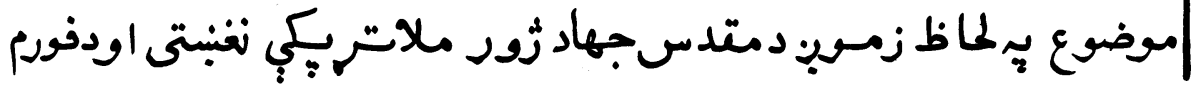

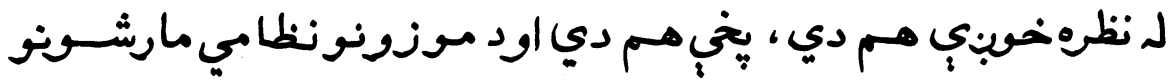

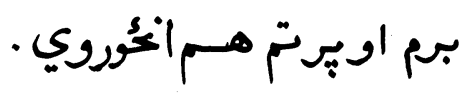

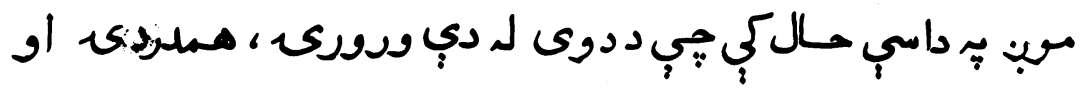

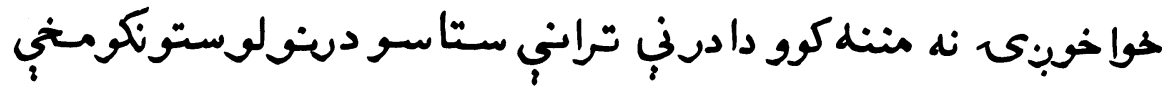

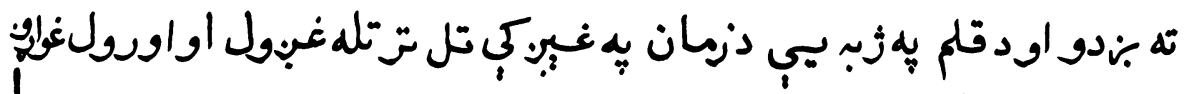

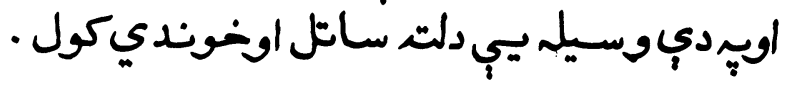

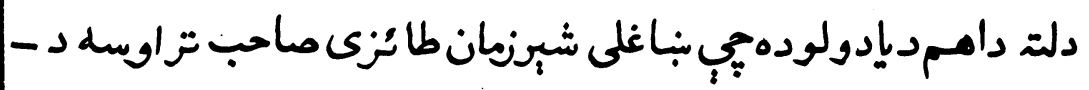

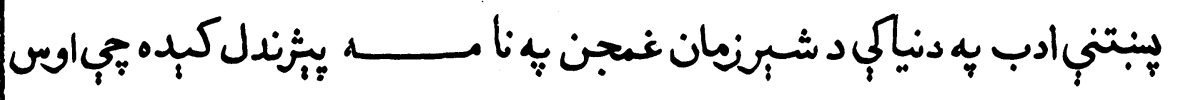

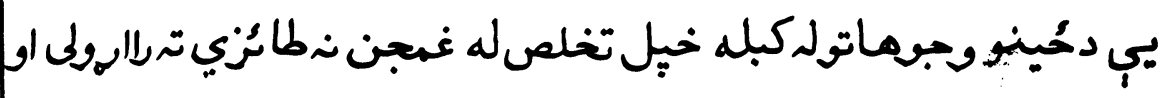
دانوى تخلص بيهي دناه: تخلص مُاى نيسي.

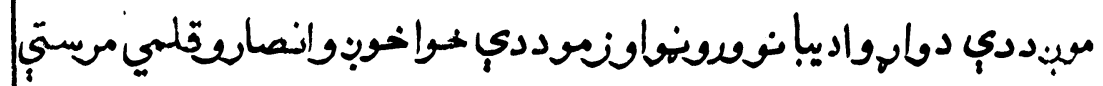

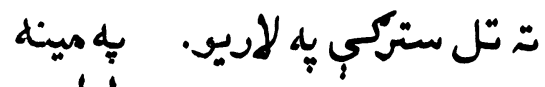

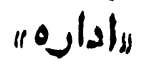


عتنم شَبرزمان طائزي

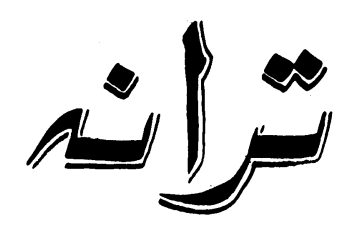

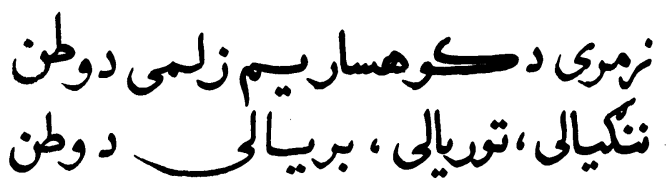

زه افنان تل دوان به قوت دايسان

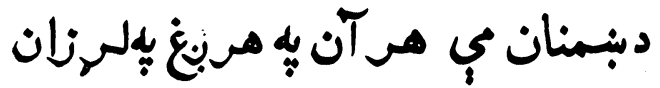

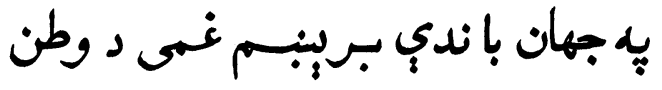

ثنكيالى ،تويالى ، بريالح د وطن

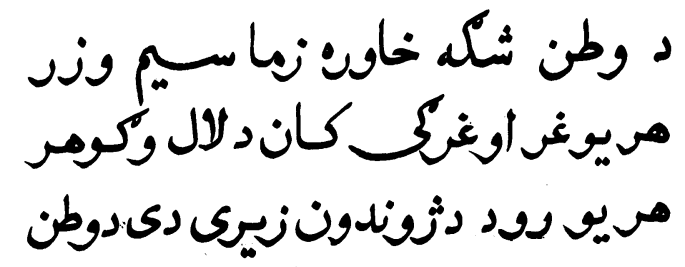

ننكيالى ، توريالى ، بريالى دوطن 


Ar دورى تصاني

زما روح دىوطن زيما تن دى وطن

زما ثموند دى وطن زما فن دى وطن

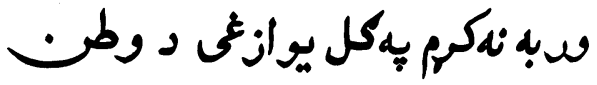

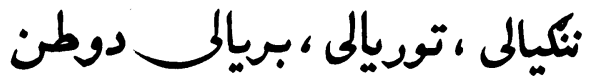

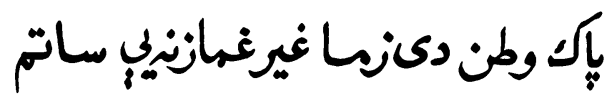

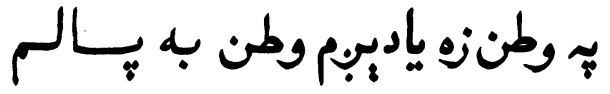

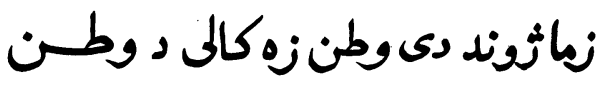

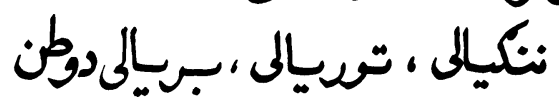

نثكيالى ، تقيالى ، بـيالى د وطن

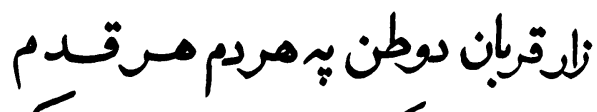

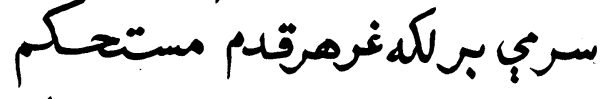

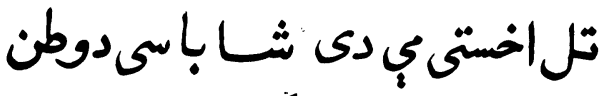


مترقممالنزيان قمرطائزى

دافغانبجامدترانه

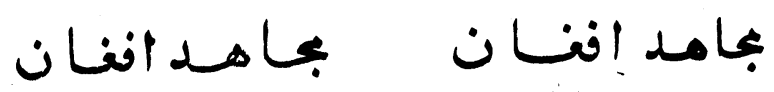

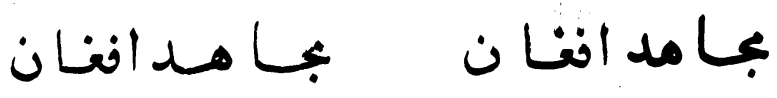

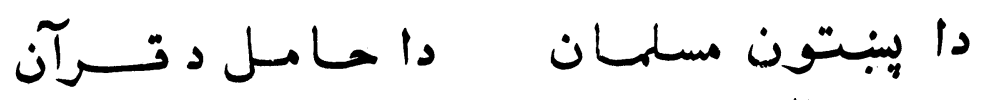

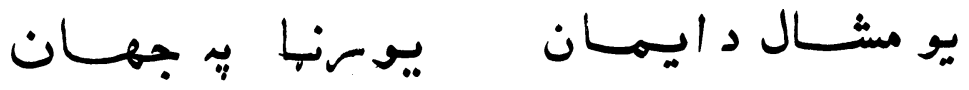

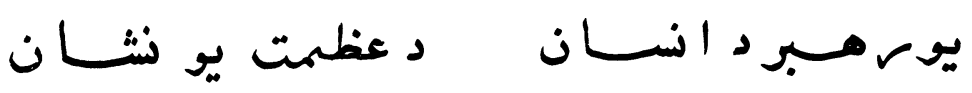

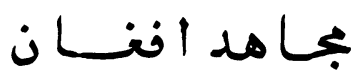

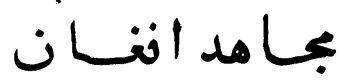

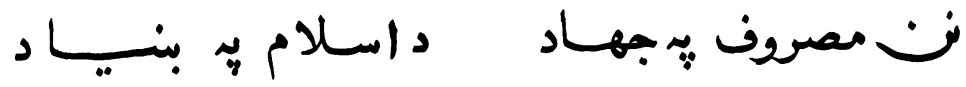

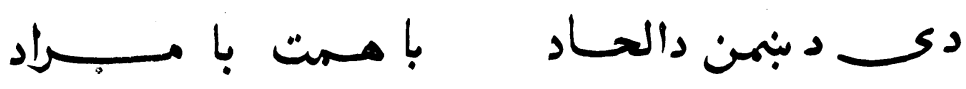

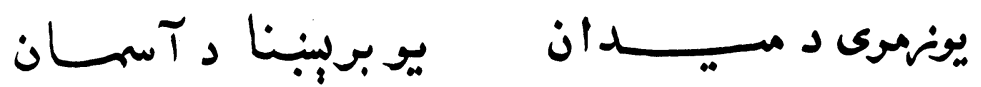
بامسد انفــان بمامدانفان 


A0

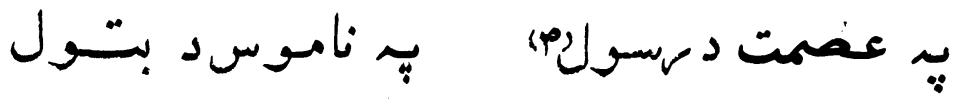

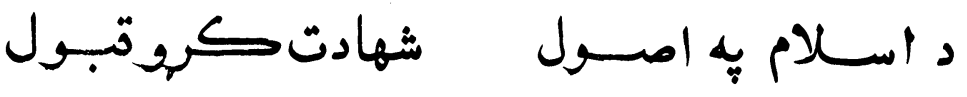

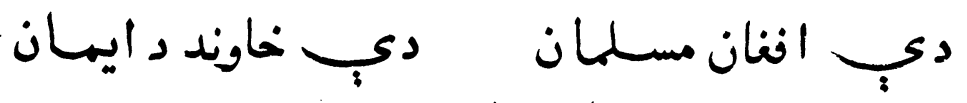

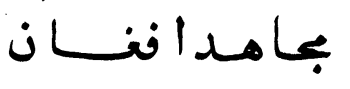

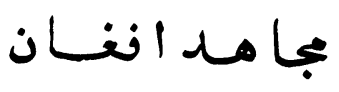

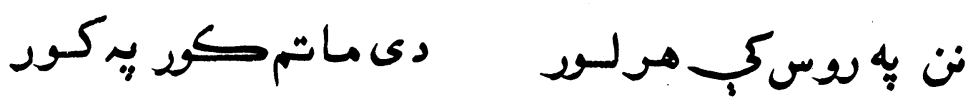

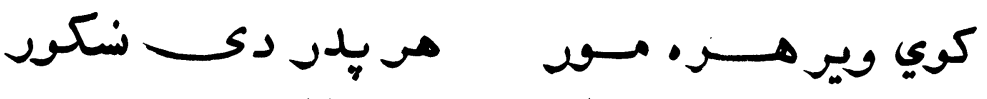
مي كثرل نشي موريسان

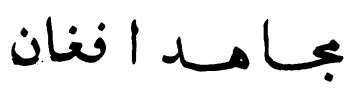

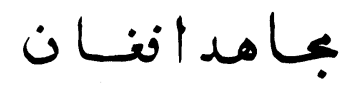

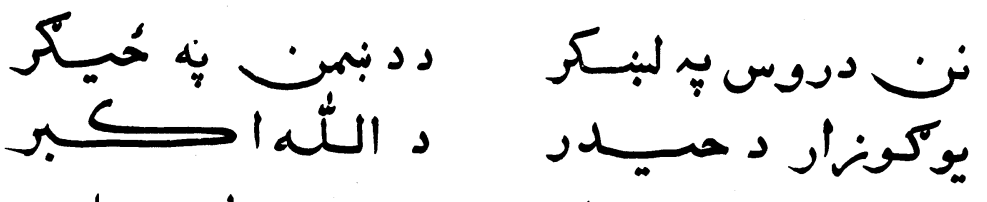

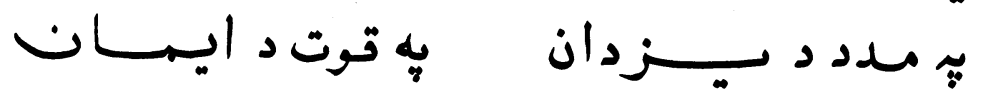

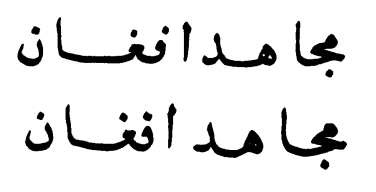


نوراحسمد احمدى

مشناعو :

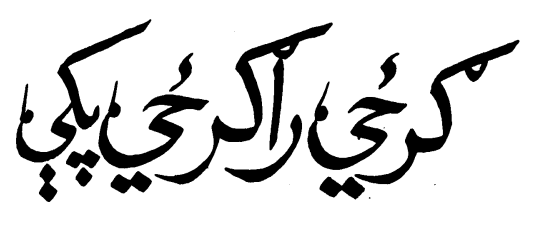

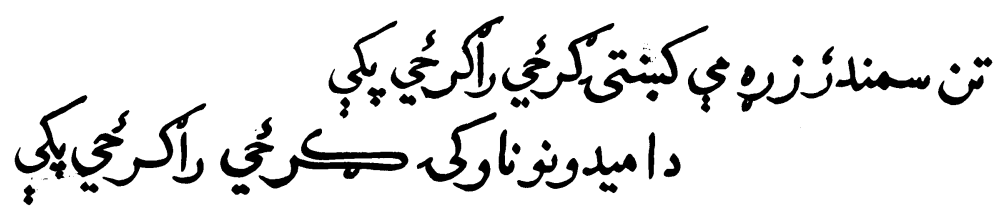

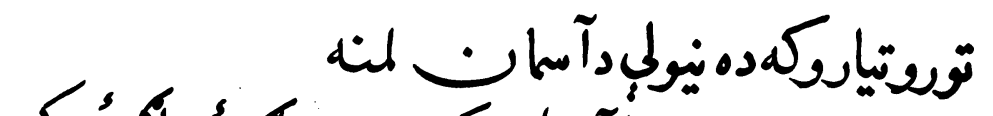

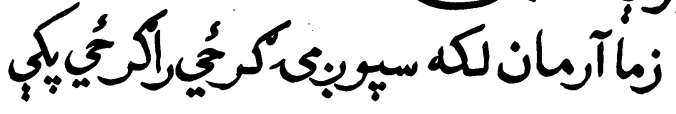

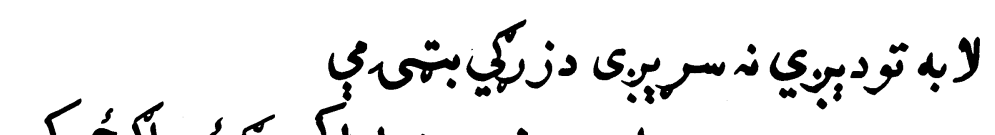

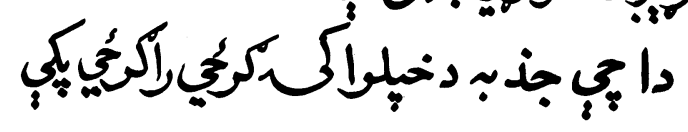

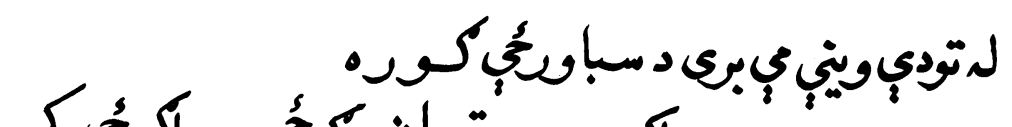

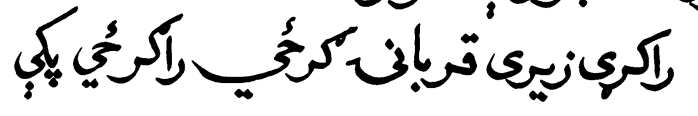

ديبت ميري بنكاري سكال له اوكنئ

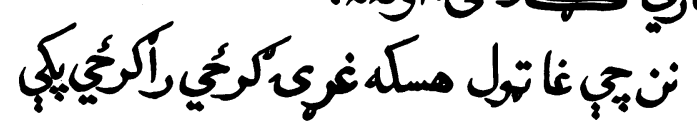


Av

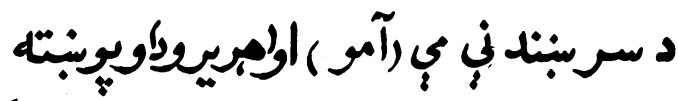

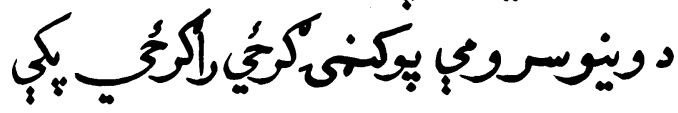

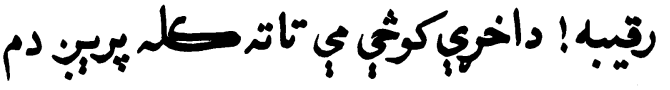

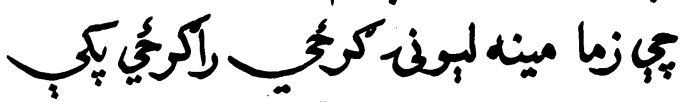

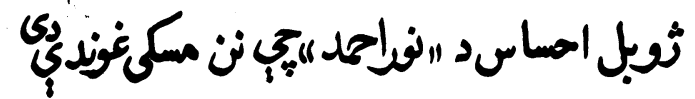

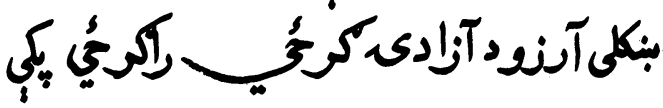

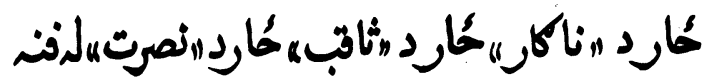

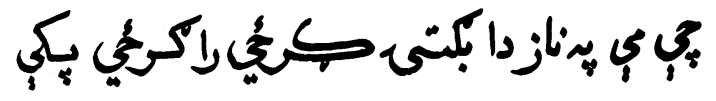

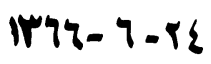

(f) 
امان الهه نصرت

فصله

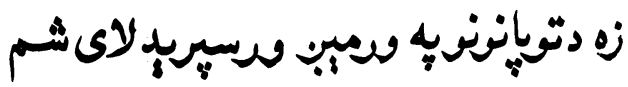

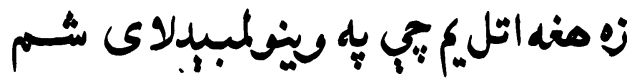

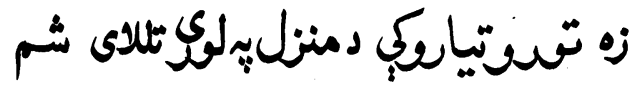

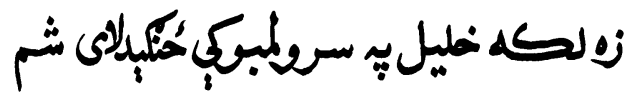

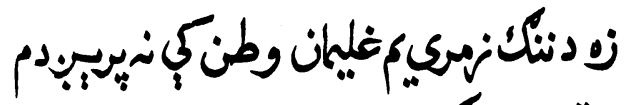

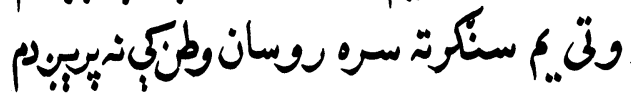

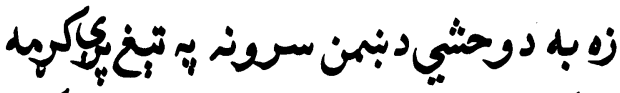

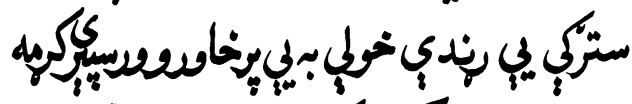

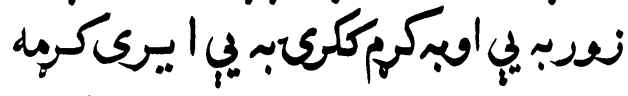

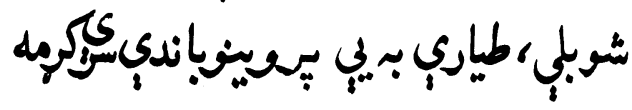

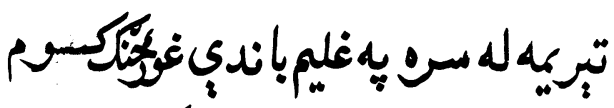

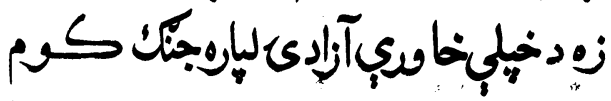




ف9 نيصلd

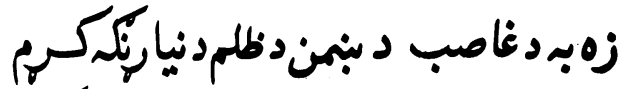

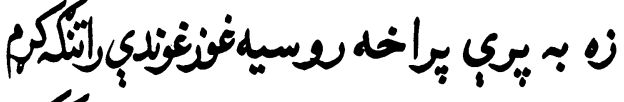

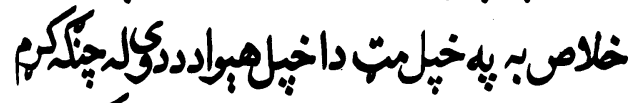

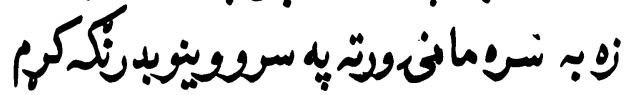

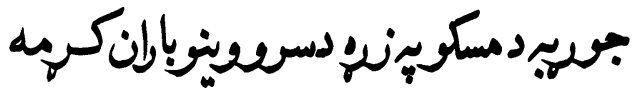

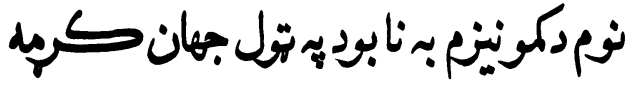

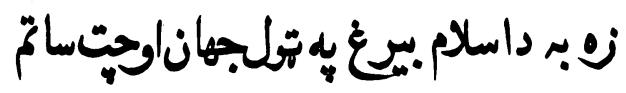

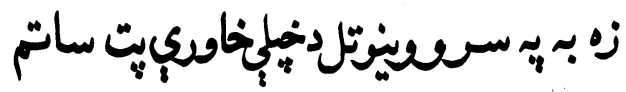

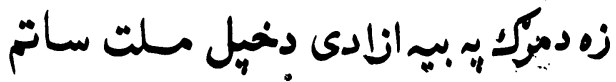

نم بـ"لثروندى زه دجهاد اوحريت ساتم

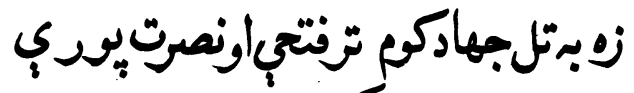

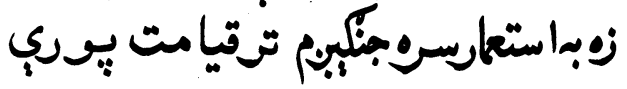

$$
\begin{aligned}
& \text { 1919/9/9 _ ناصرياغ }
\end{aligned}
$$




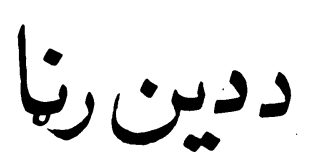

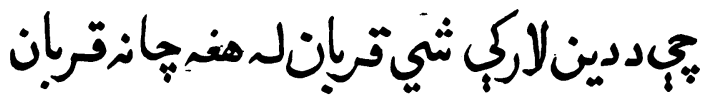

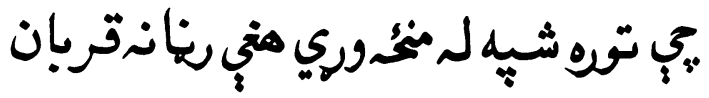

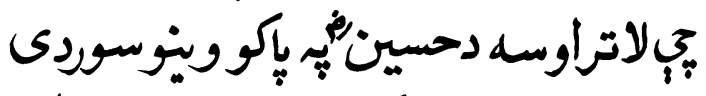

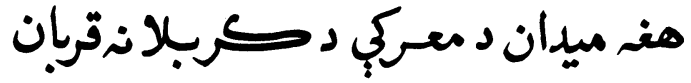

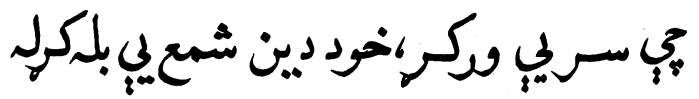

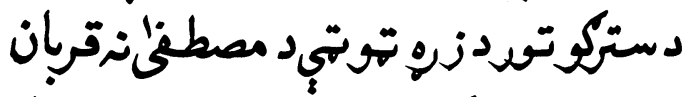

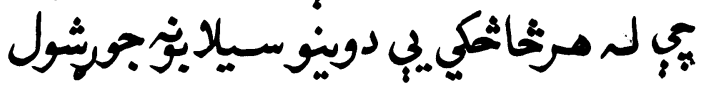

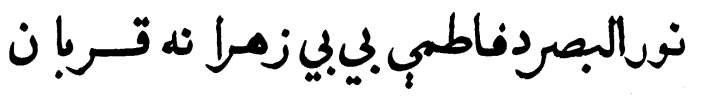

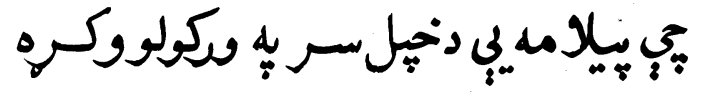

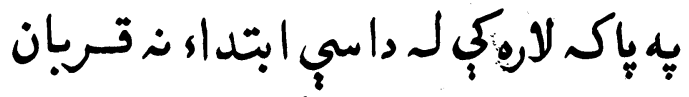

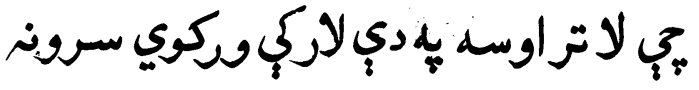

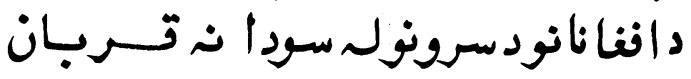

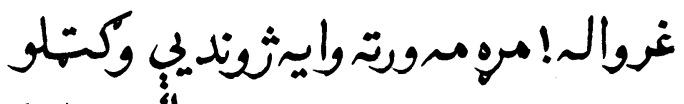

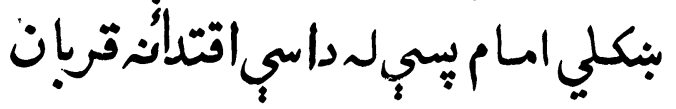

كبابيان .r/r 
النشامين

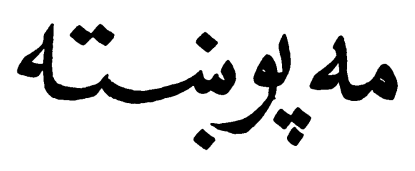

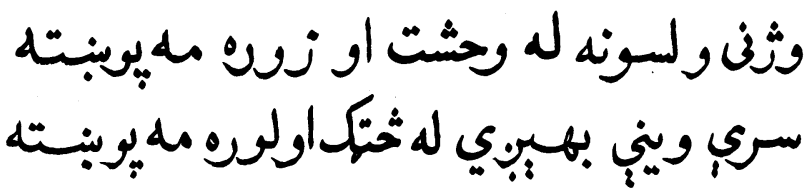

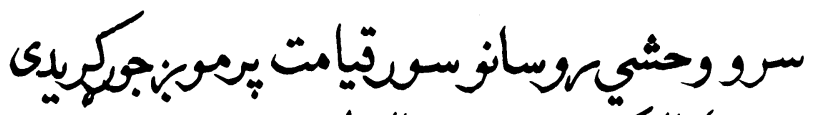

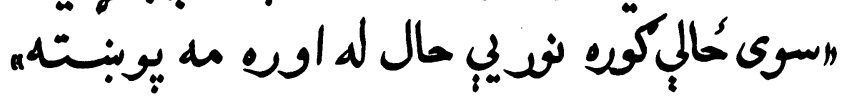

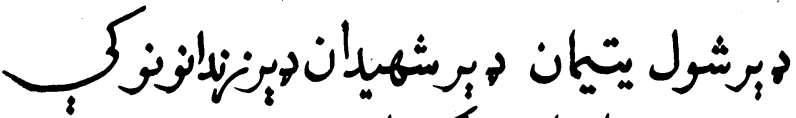

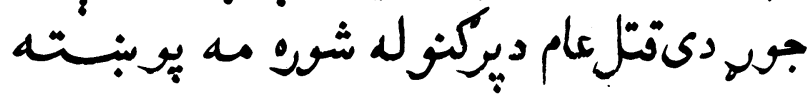

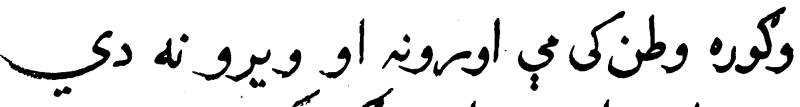

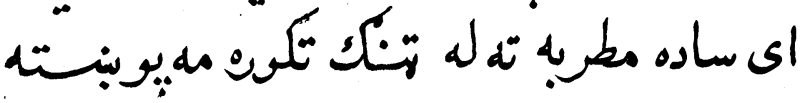


كئر بِكوماتم دىاسولي اوثرالها نيدي

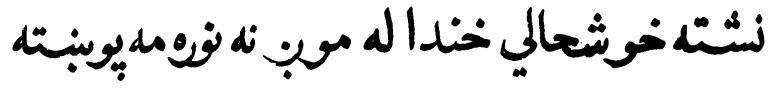

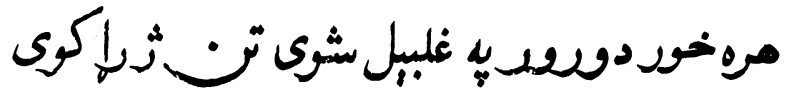

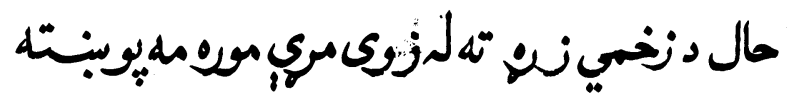

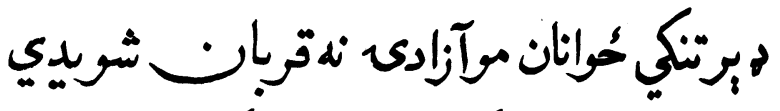

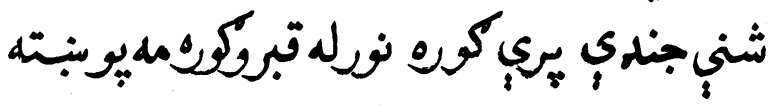

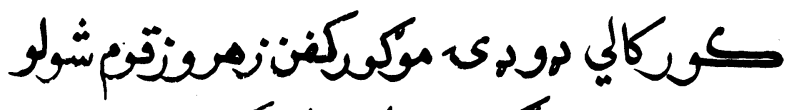

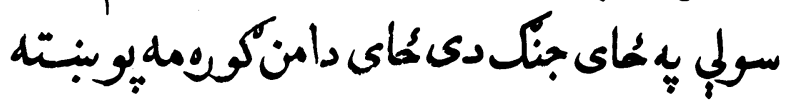

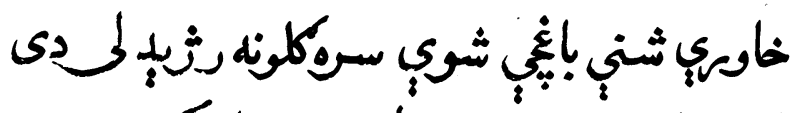

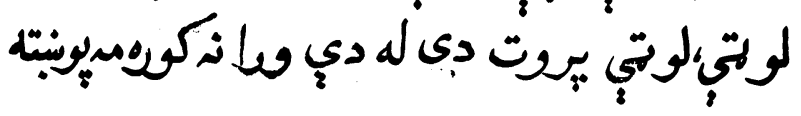




\section{العاج نتكيال}

$$
\text { تقريظ: }
$$

\section{دونوىيجإشوىتنسيرنه}

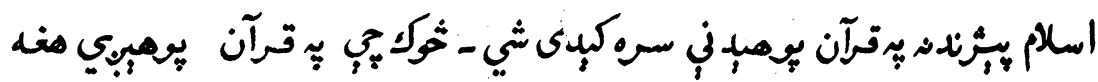

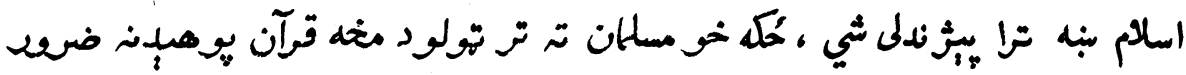

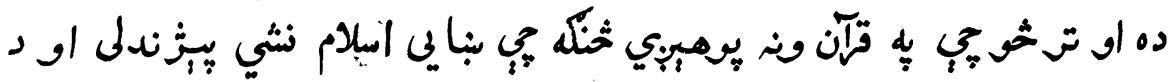

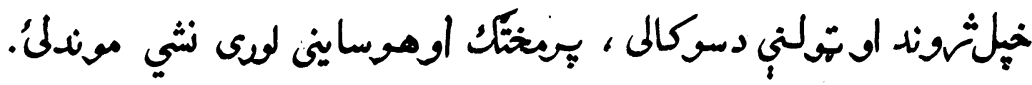

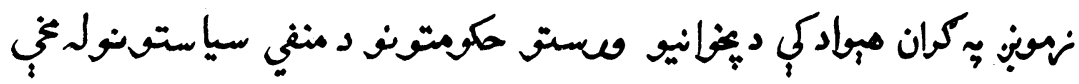

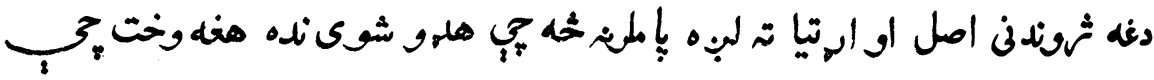

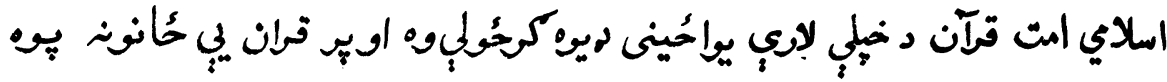

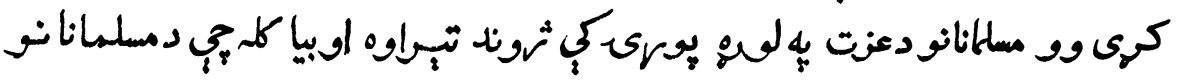

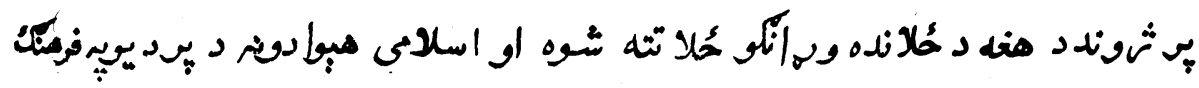

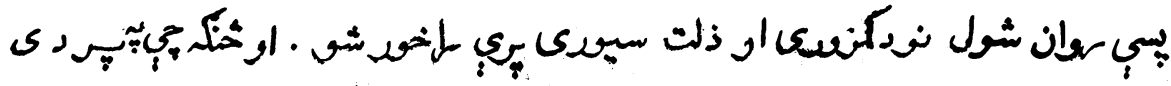

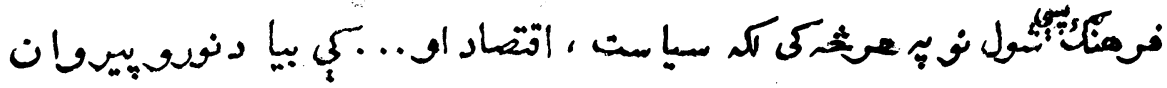
شتول . 


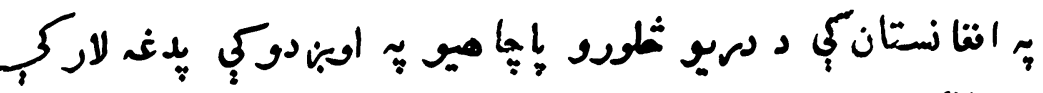

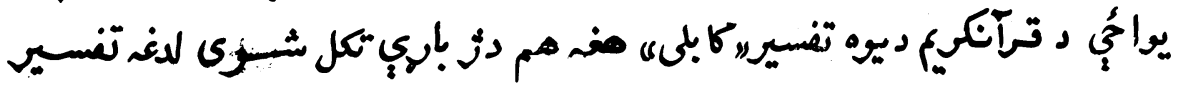

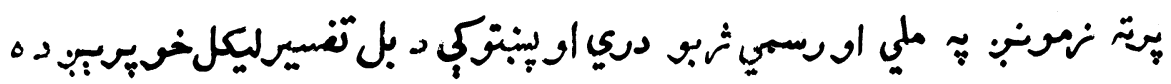

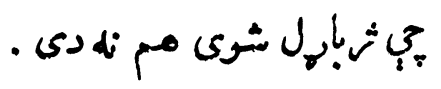

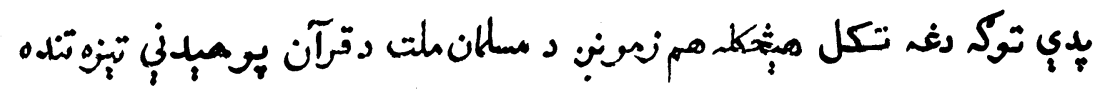

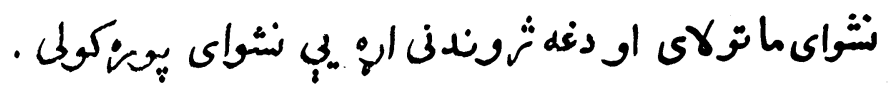

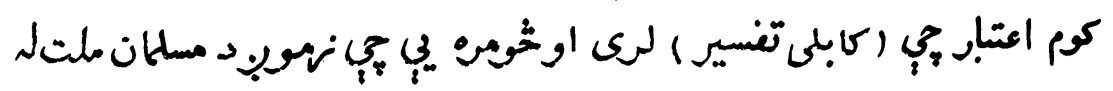

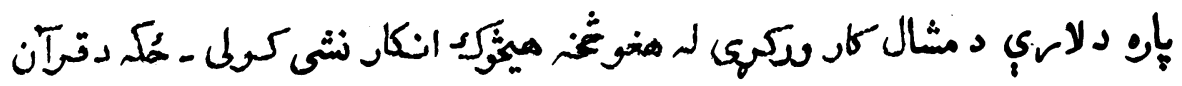

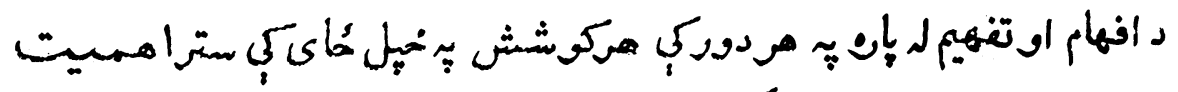

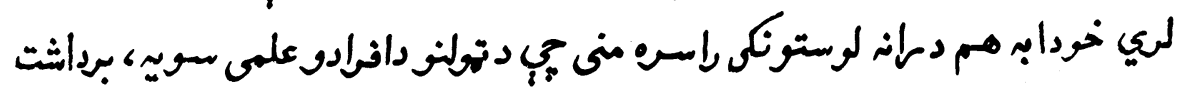

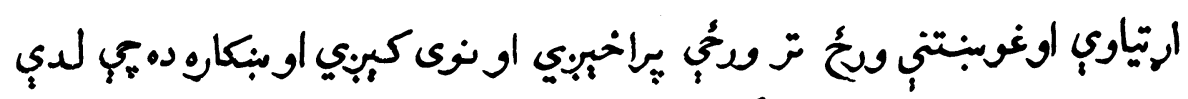

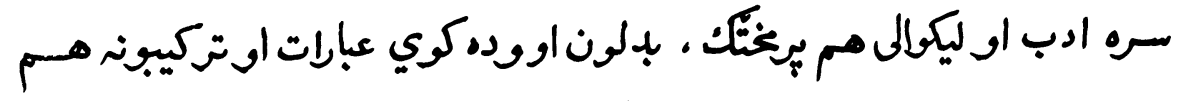

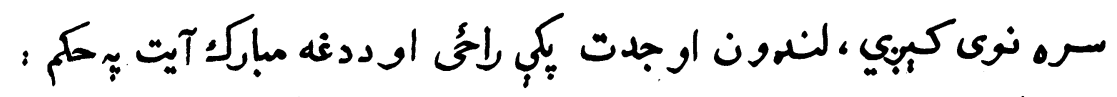

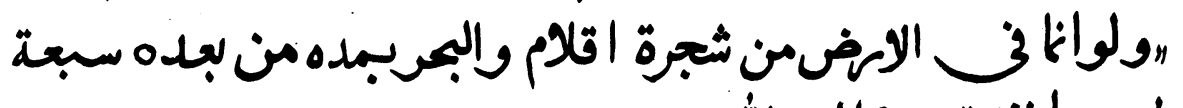

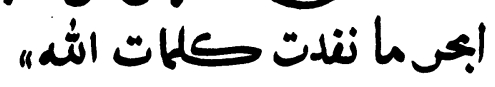

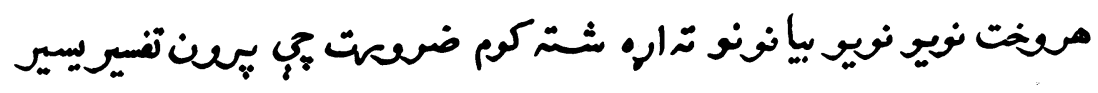

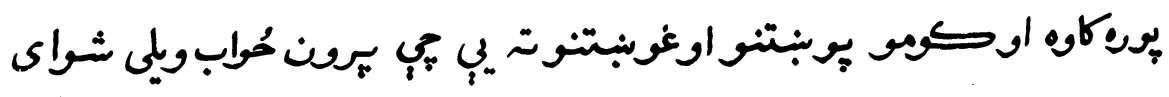

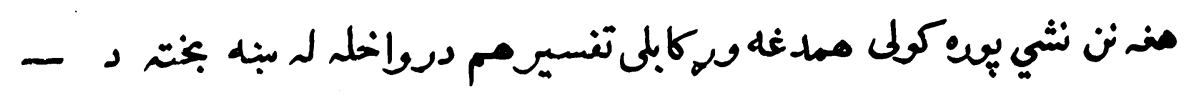

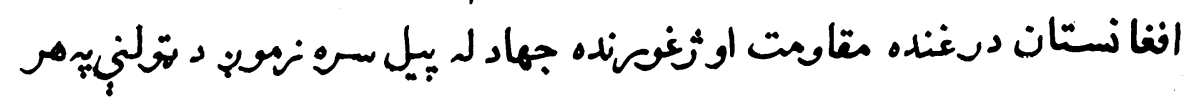




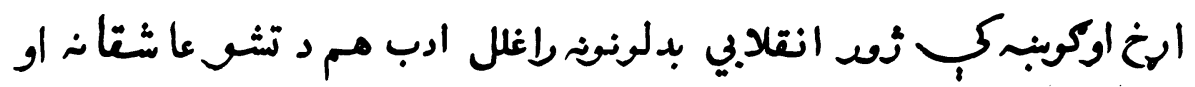

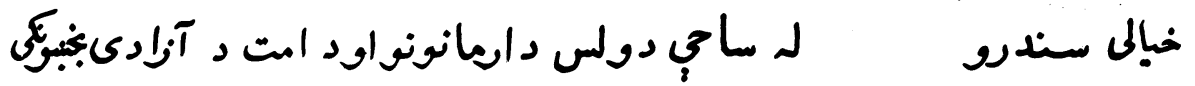

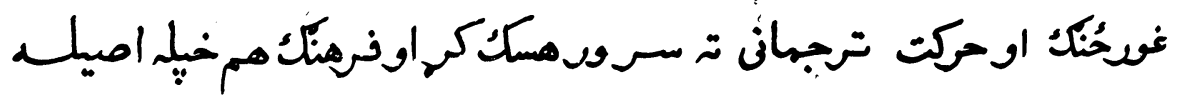

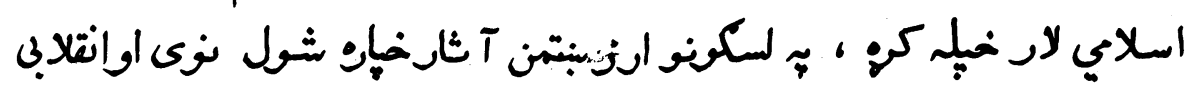

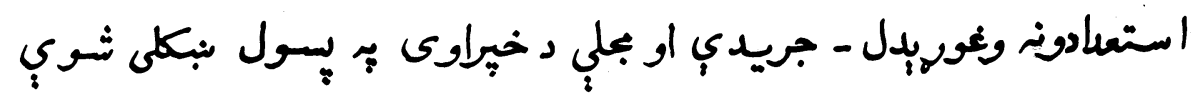

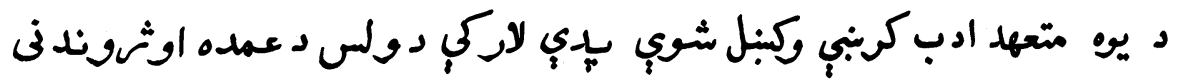

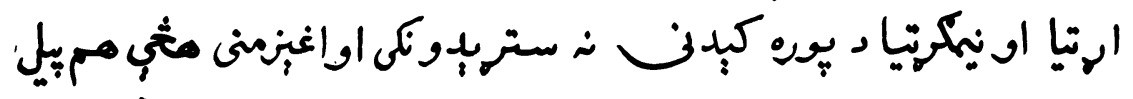

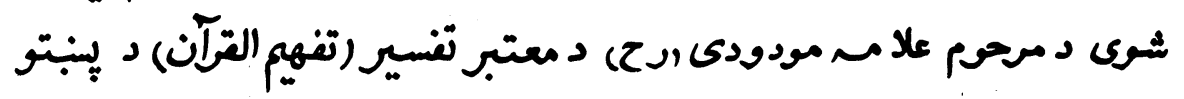

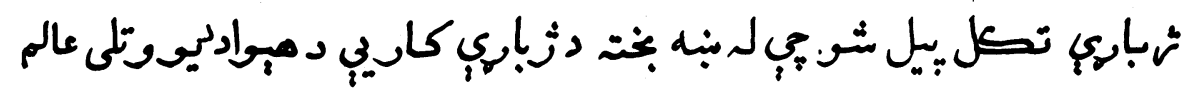

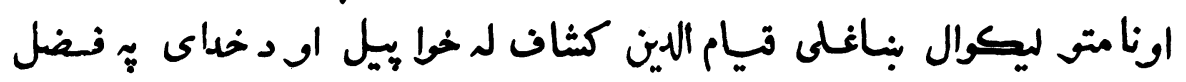

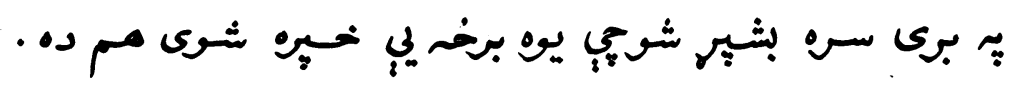

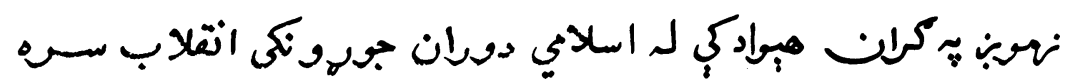

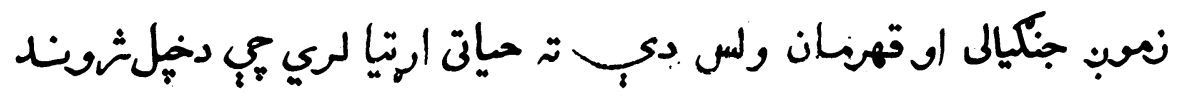

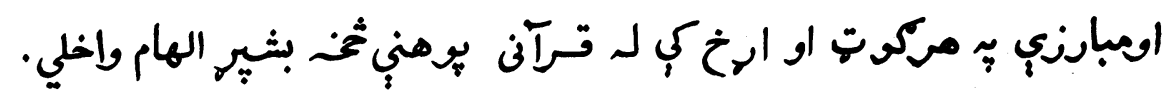

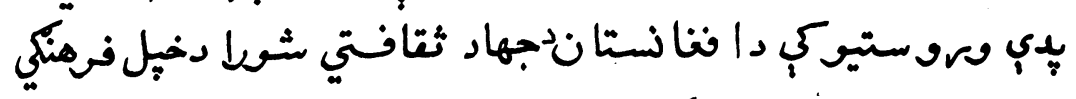

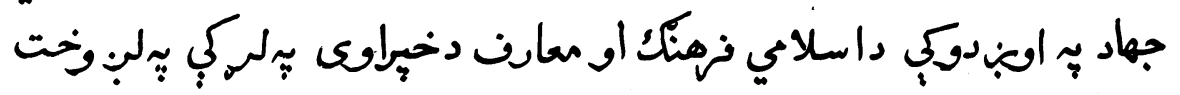

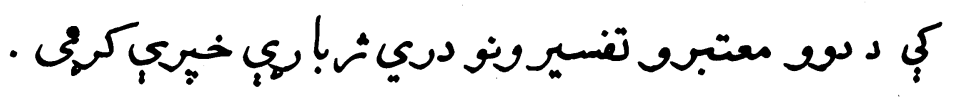

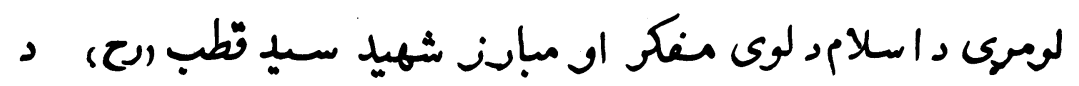

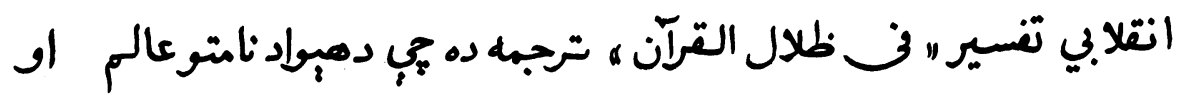




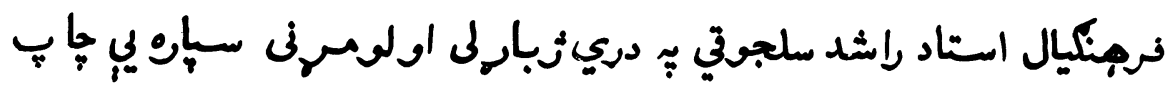

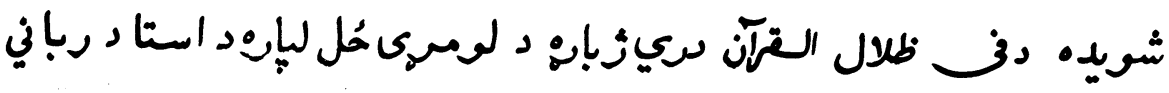

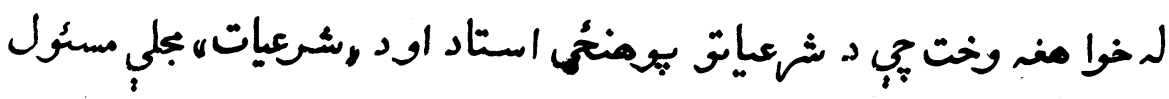

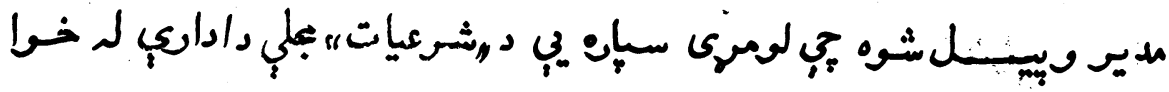

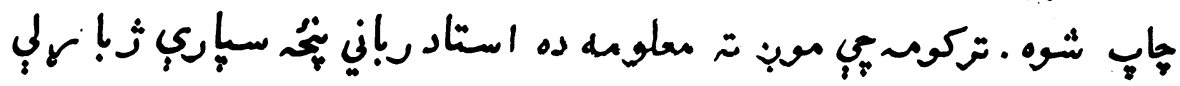

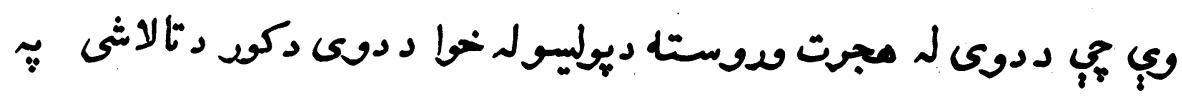

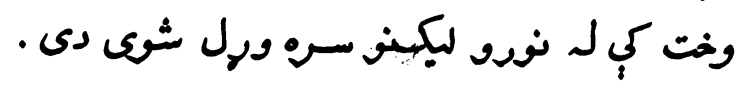

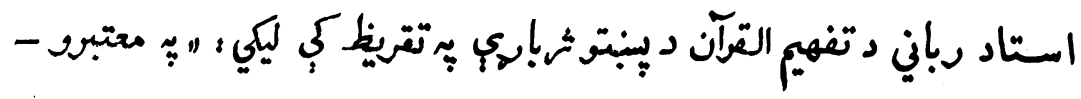

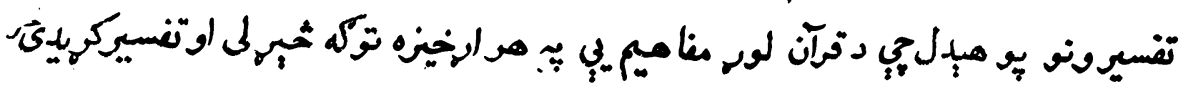

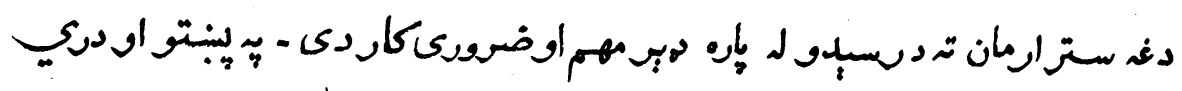

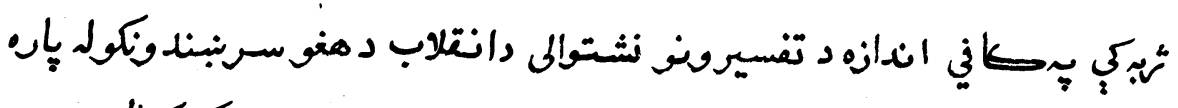

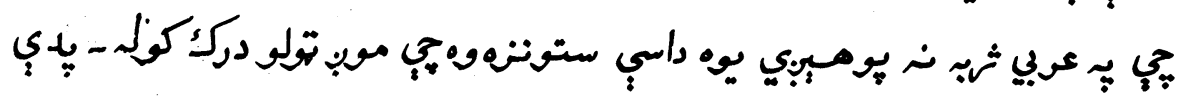

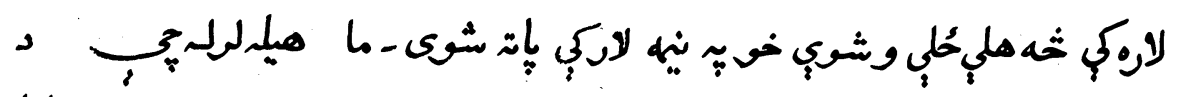

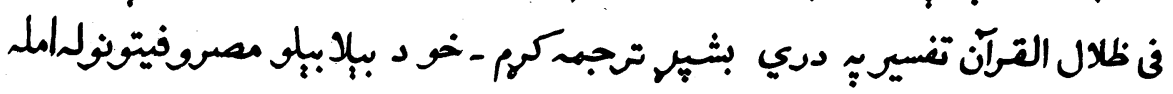

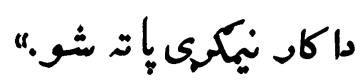

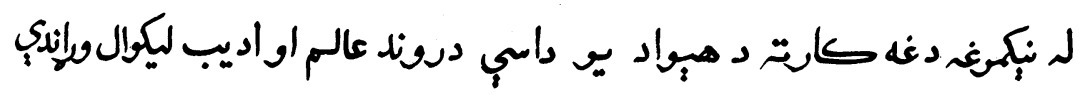

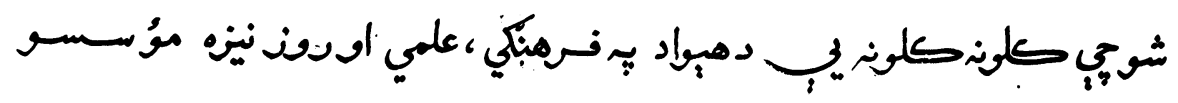

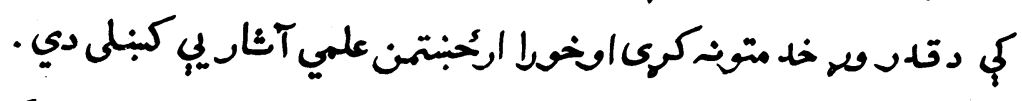

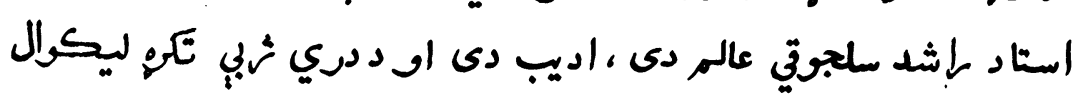




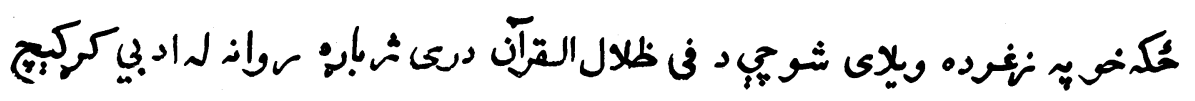

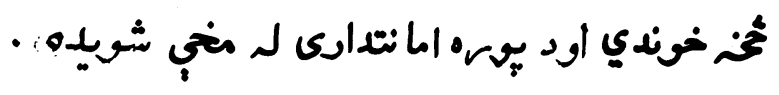

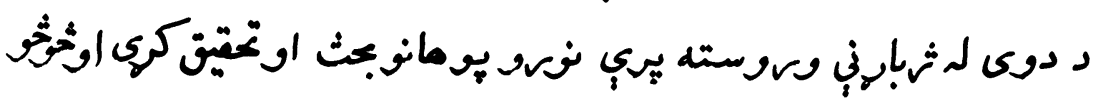

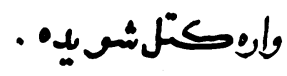

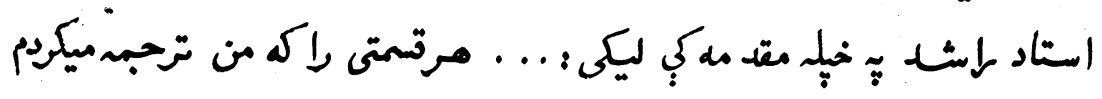

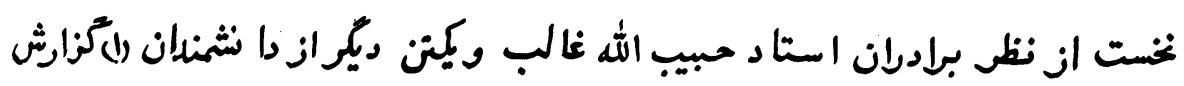

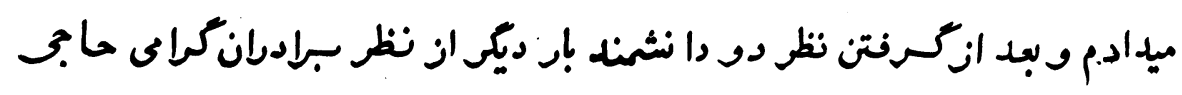

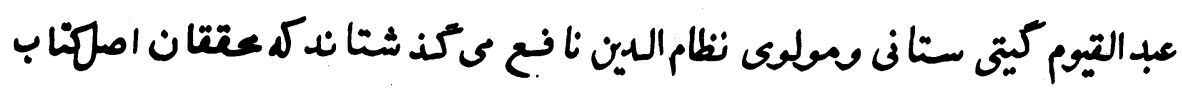

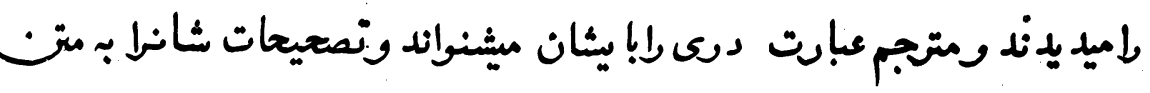

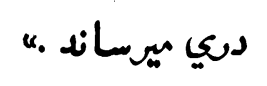

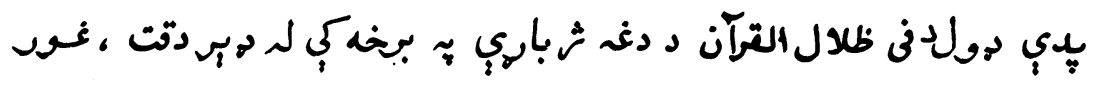

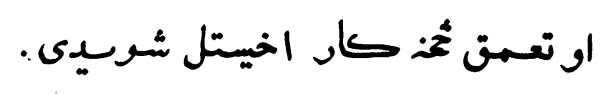

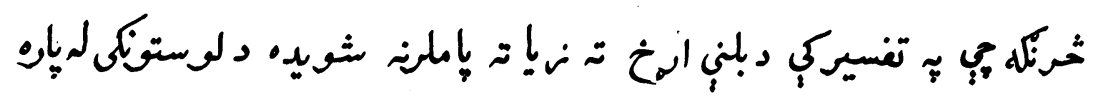

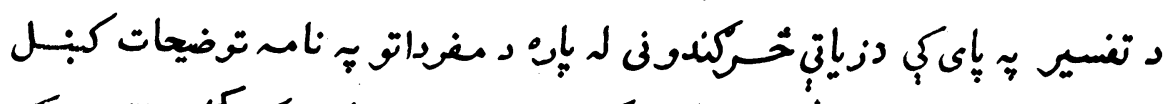

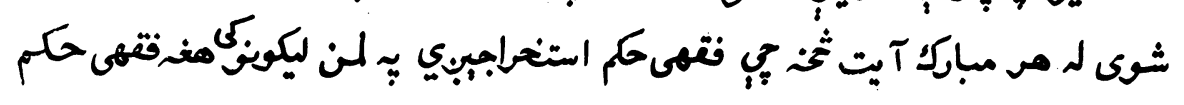

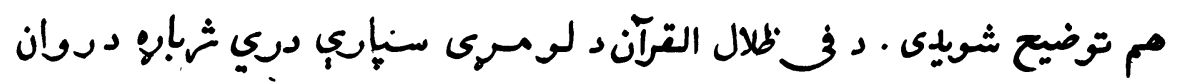

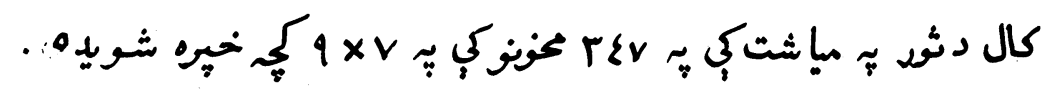

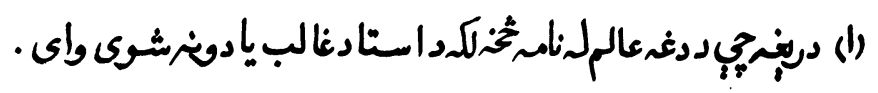




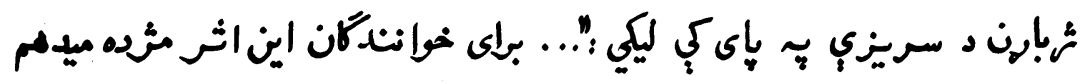

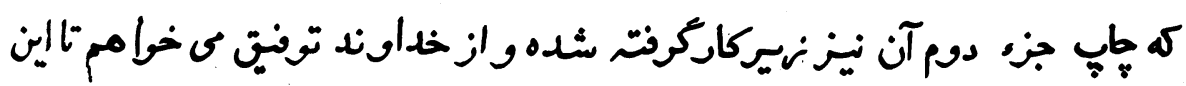

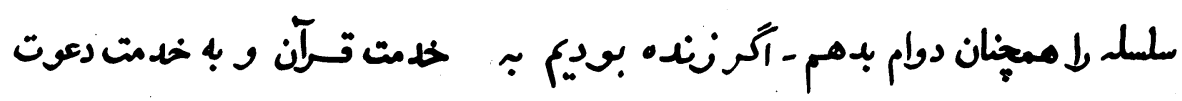

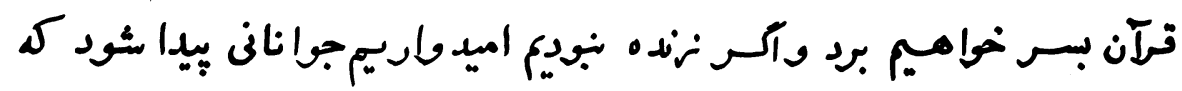

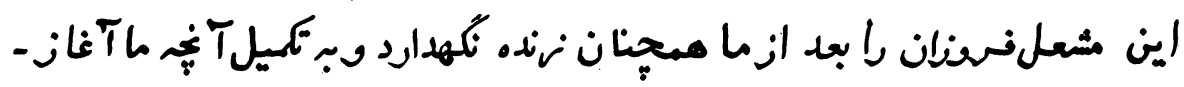

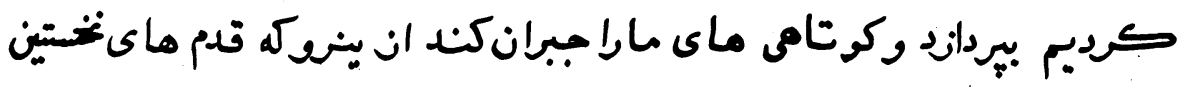

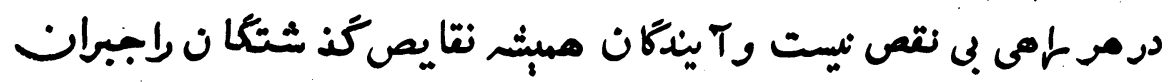
ميكند

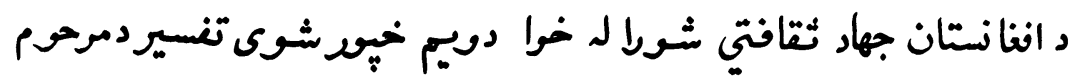

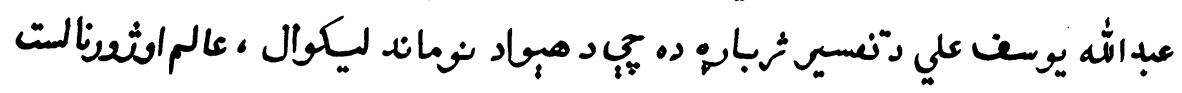

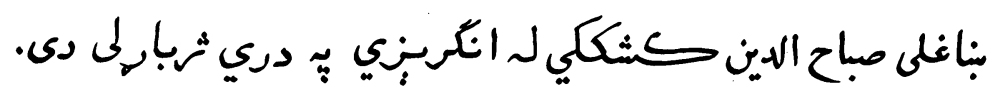

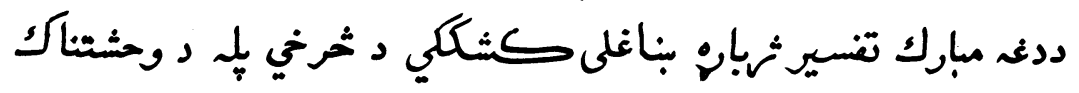

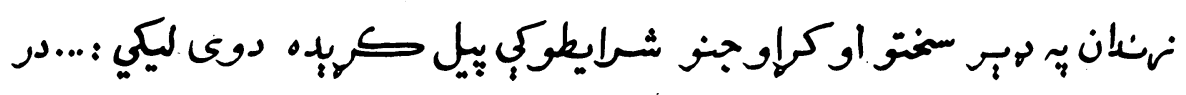

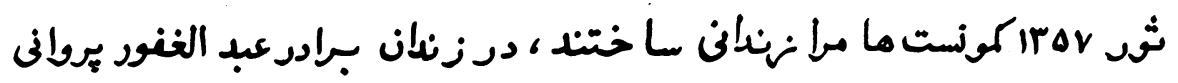

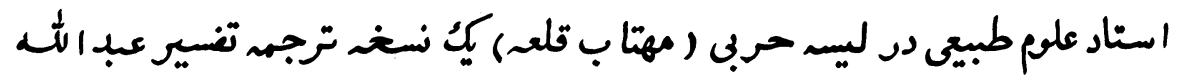

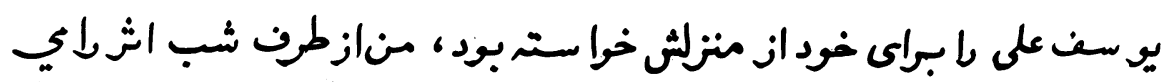

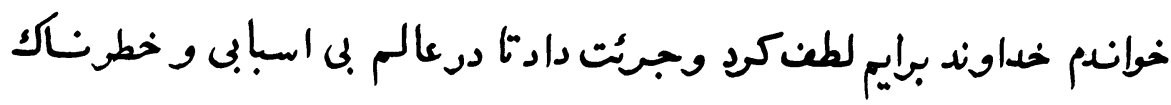

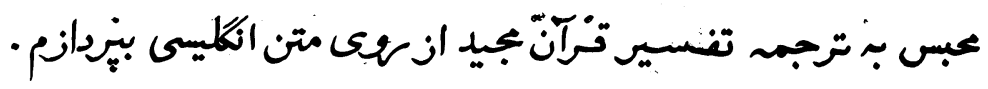

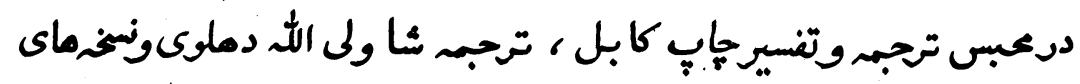




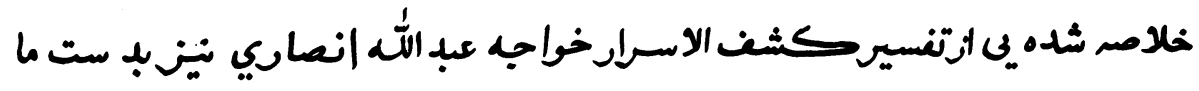

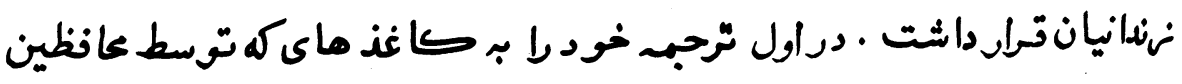

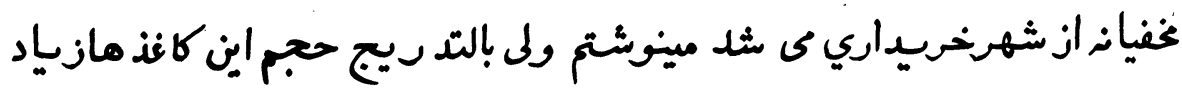

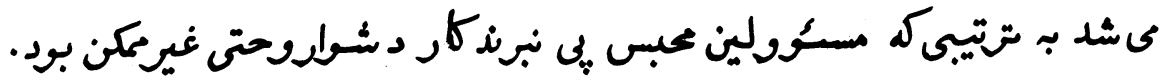

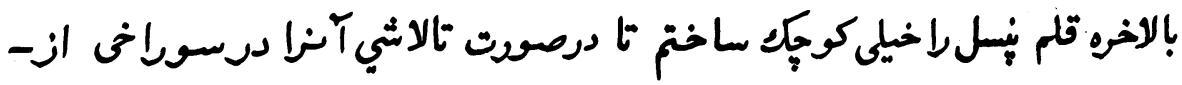

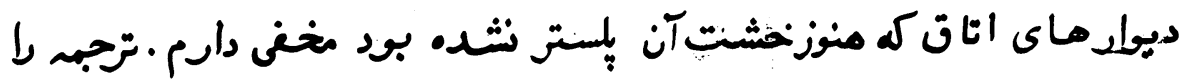

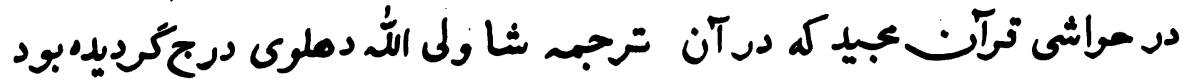

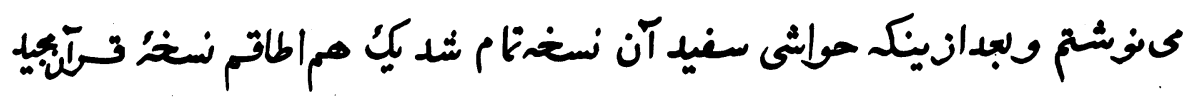

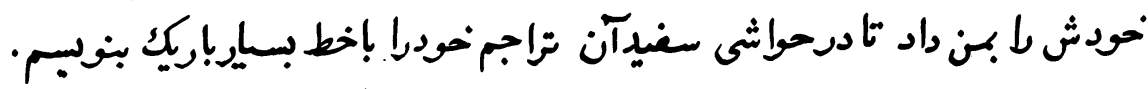

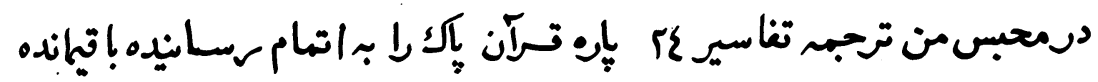

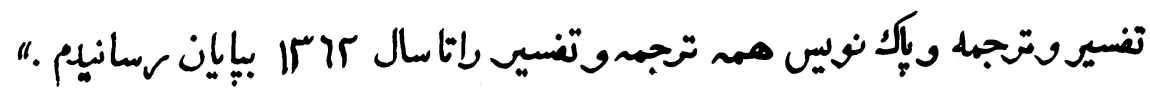

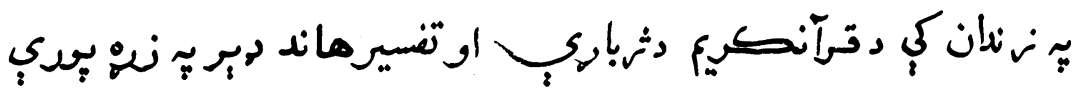

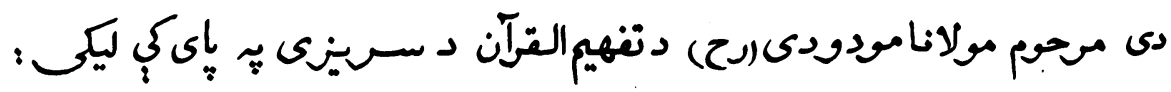

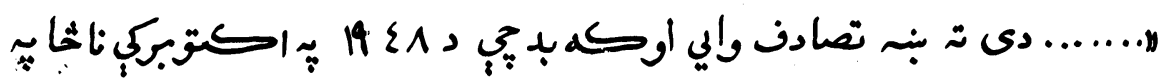

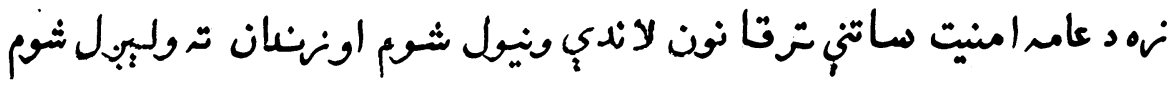

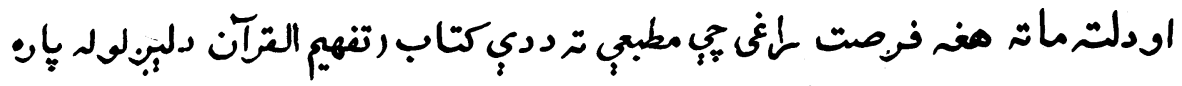

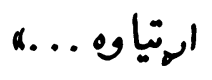

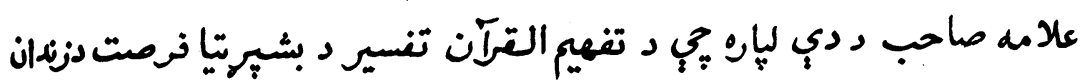

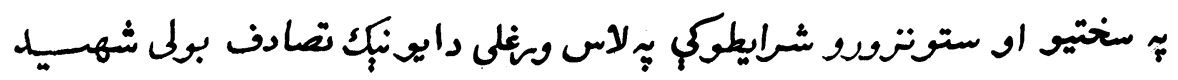




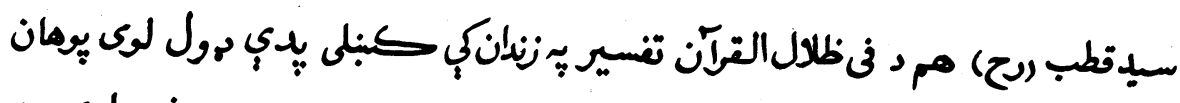

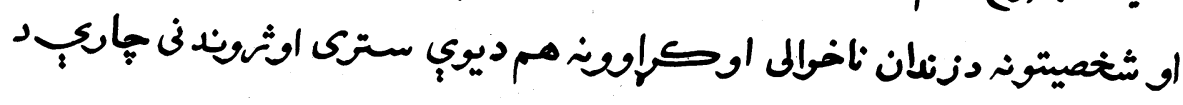

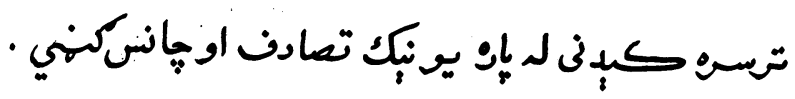

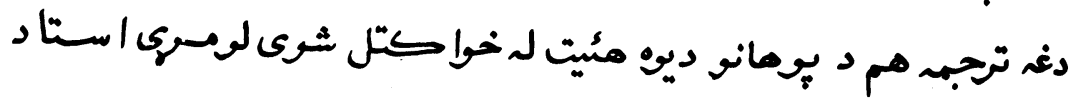

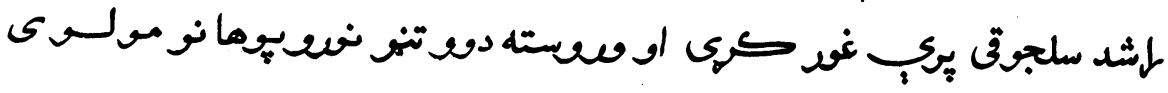

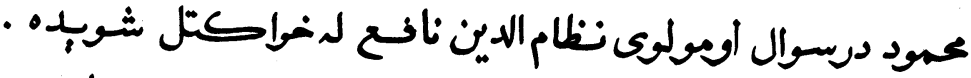

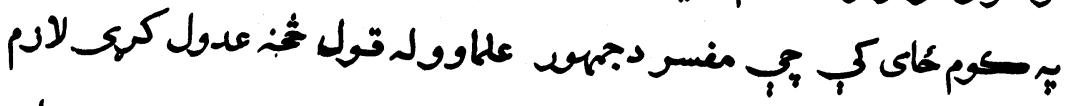

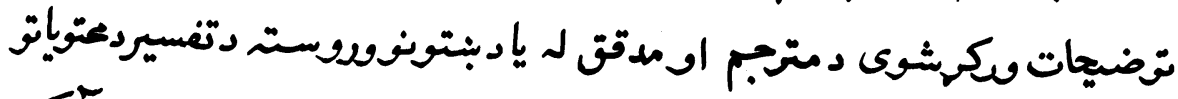

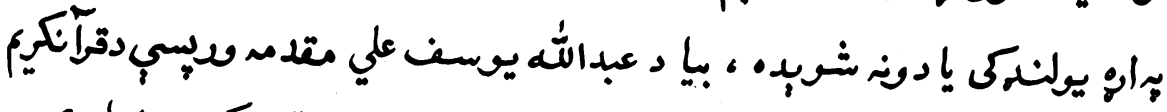

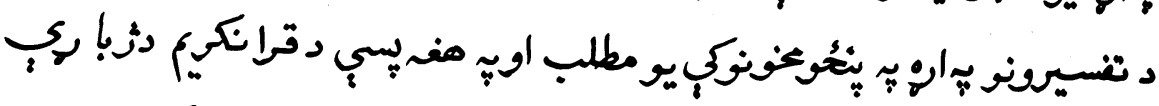

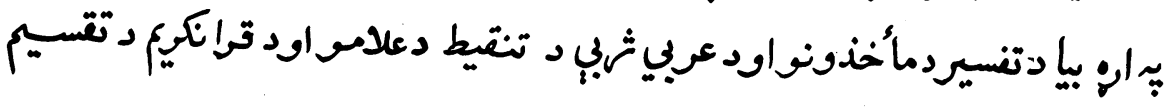

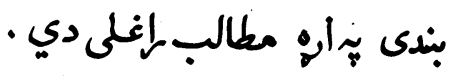

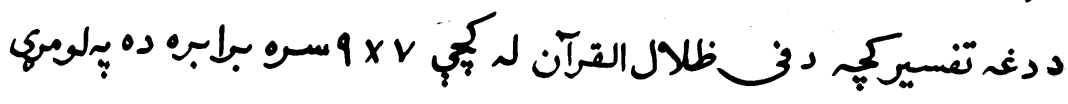

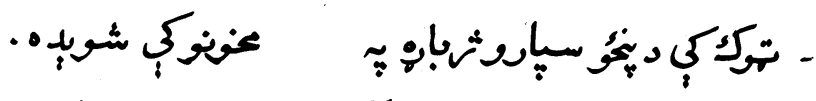

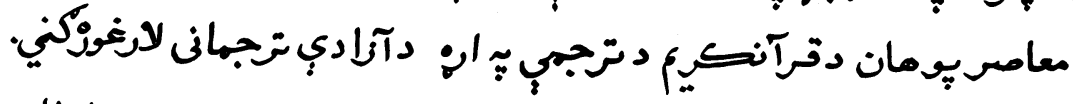

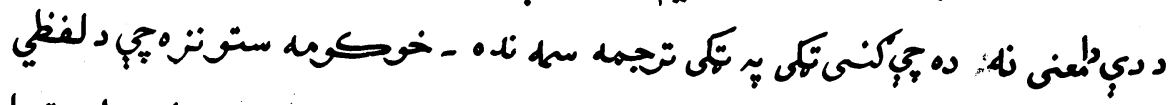

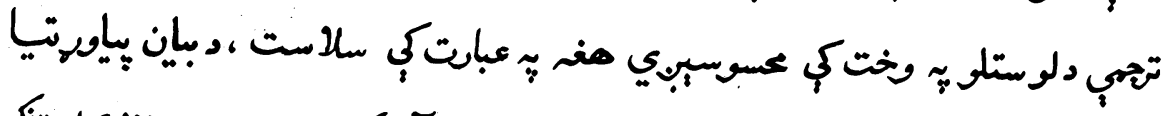

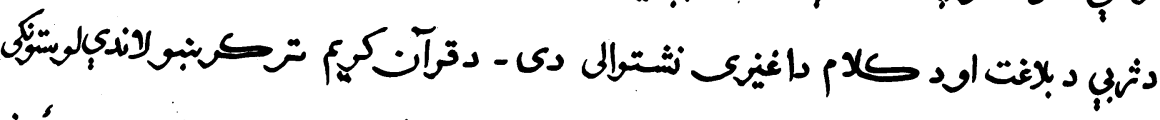

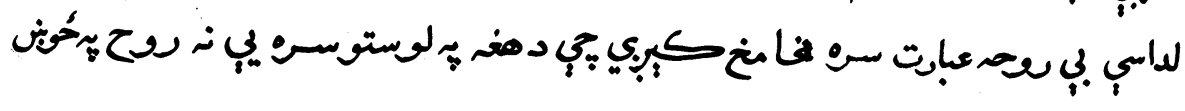




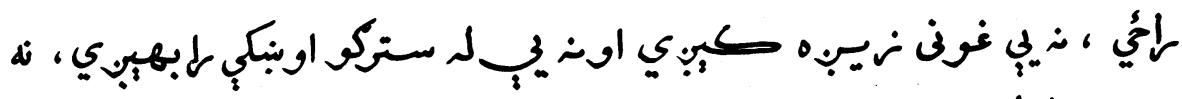

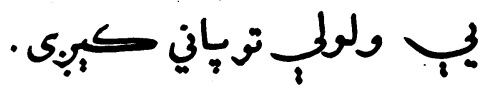

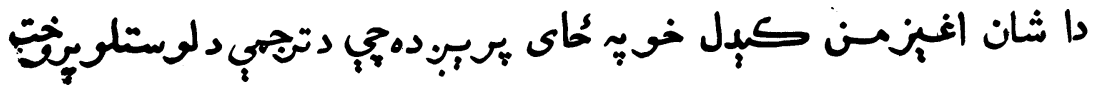

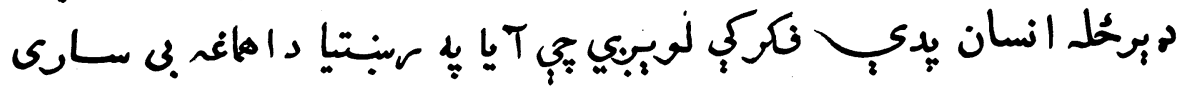

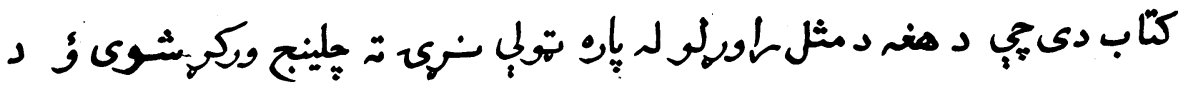

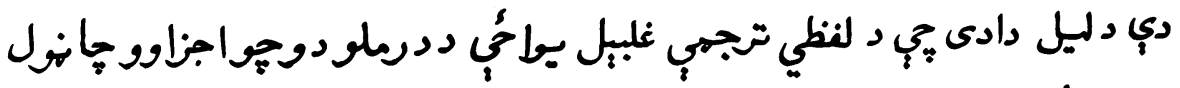

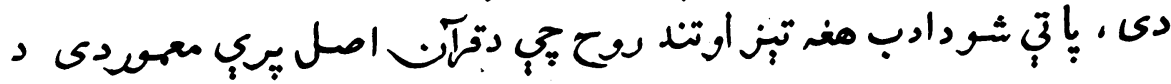

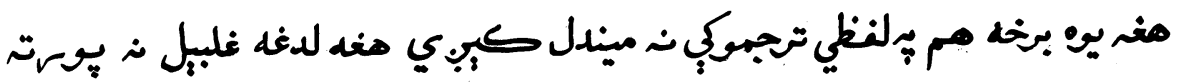

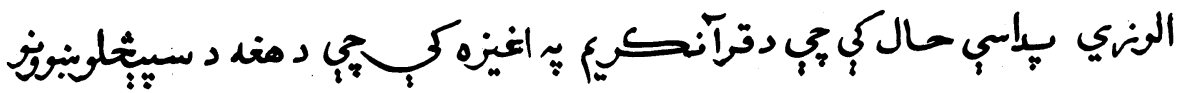

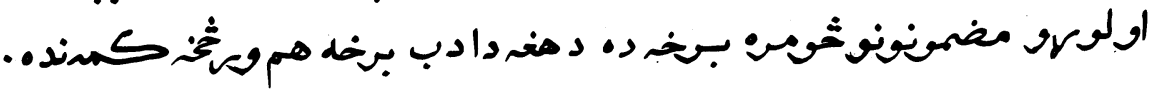

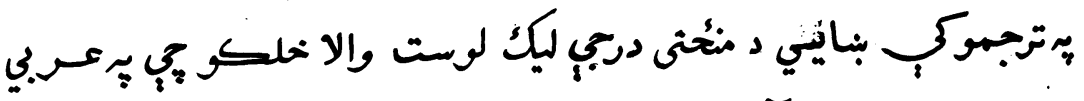

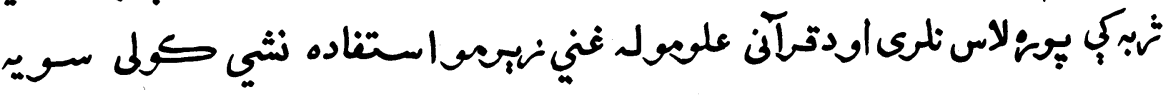

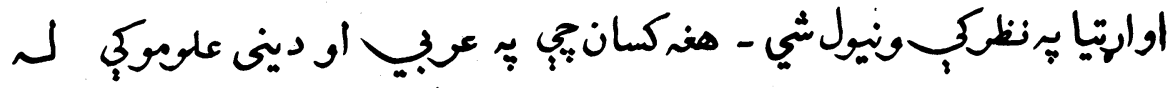

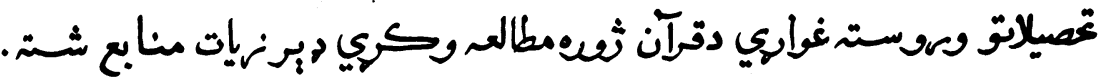

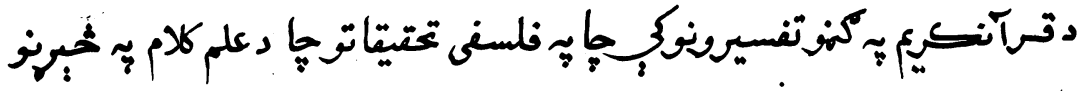

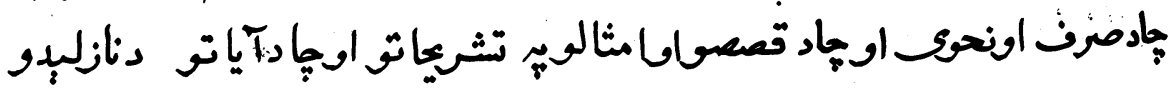

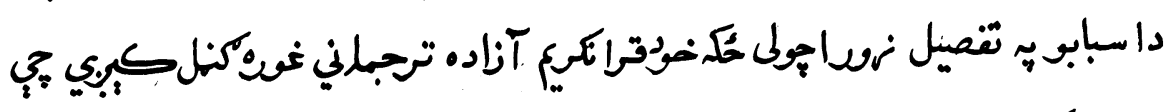

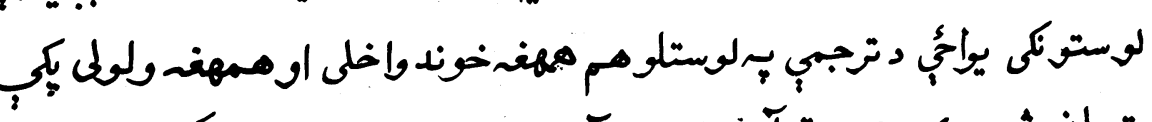

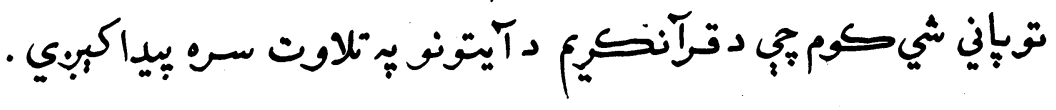




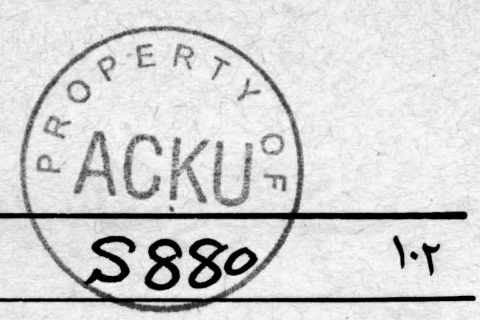

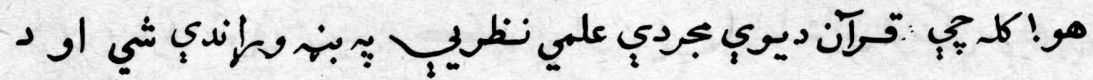

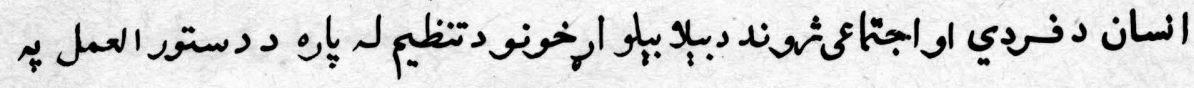

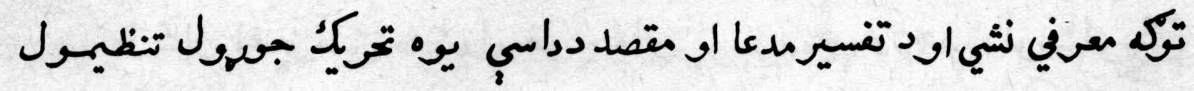

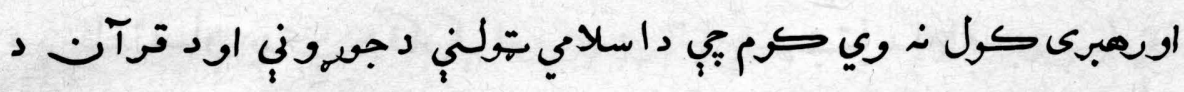

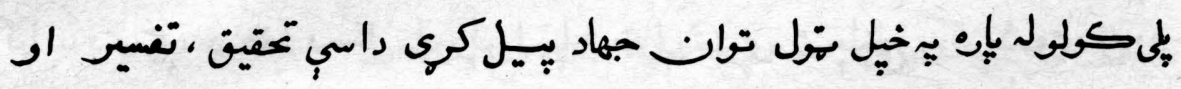

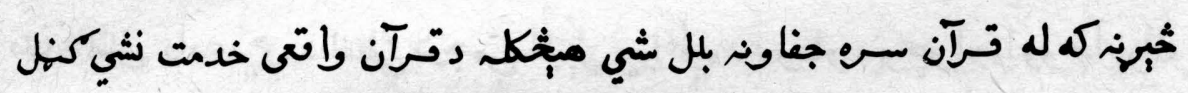
-

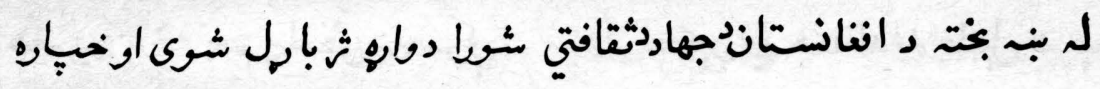

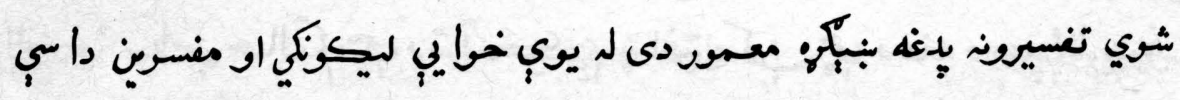

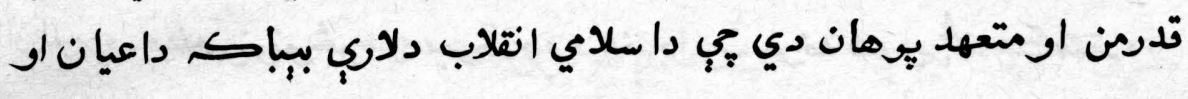

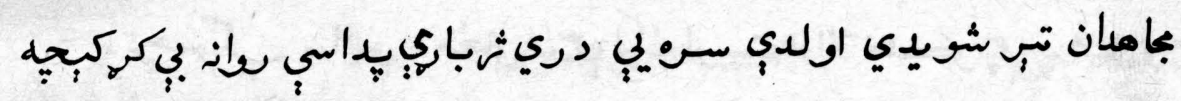

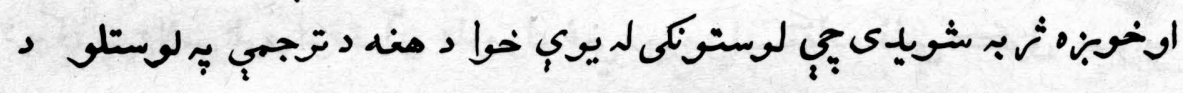

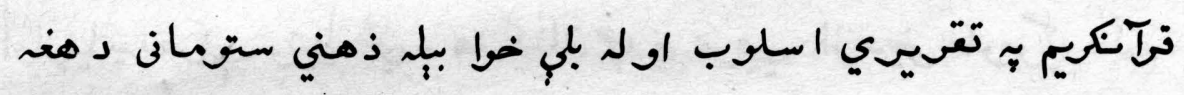

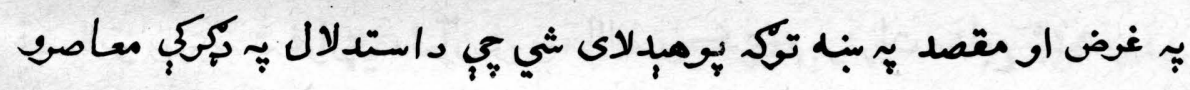

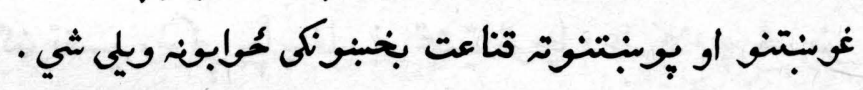

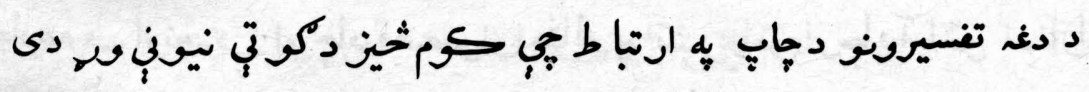

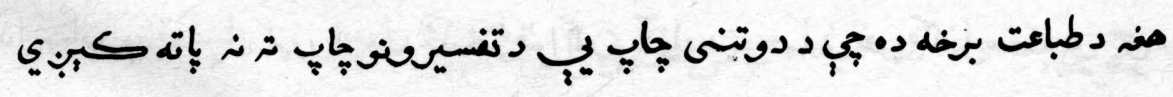

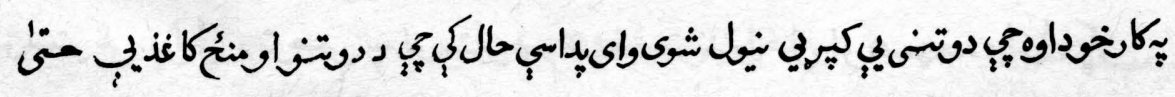

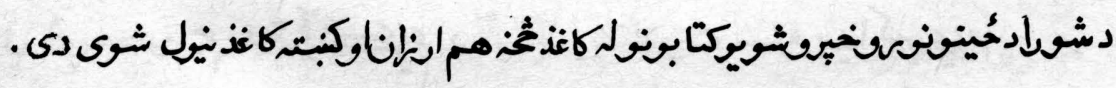




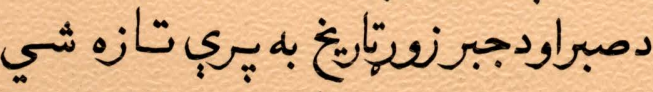

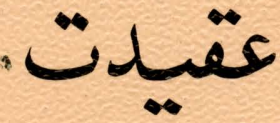

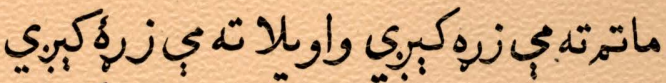

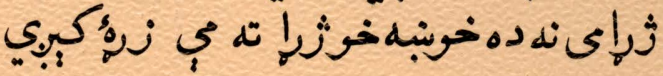

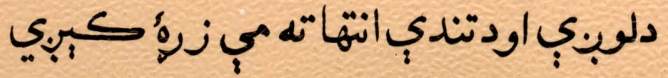

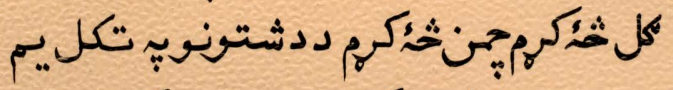

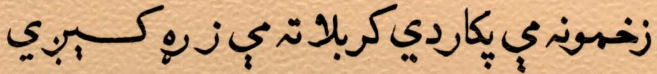

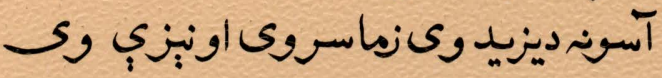

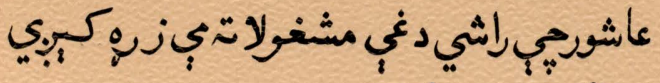

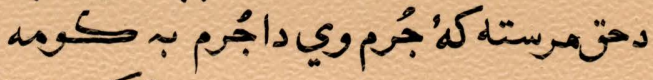

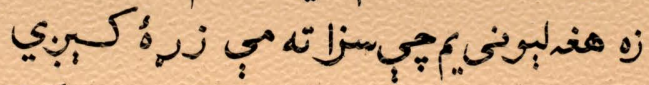

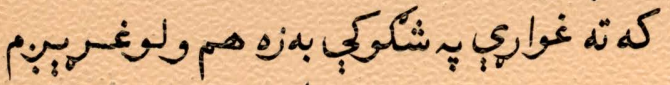

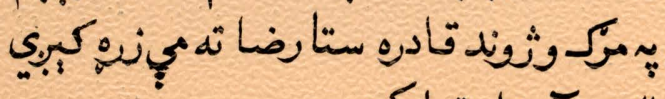

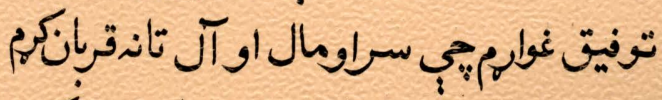

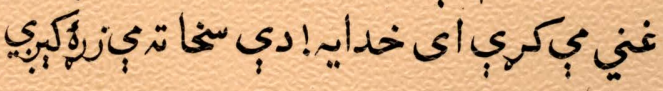

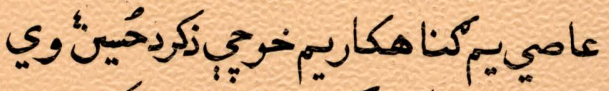

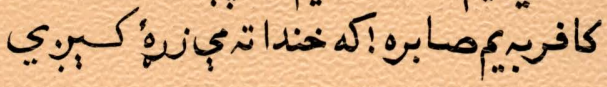
ايوبهابس 


\section{QALAM}

BI-MONTHLY JOURNAL OF THE JEHAD RESEARCH CENTRE OF AFGHANISTAN

(JRCA)

Annual Subscription:

Pakistan: Rs. 100 per copy Rs. 20

Other countries: $\$ .25$ per copy $\$ .5$

Address:

Jehad Research Centre of Afghanistan

G.P.O. Box 1155

Peshawar Pakistan
Bank account

No. 3009

Habib Bank

Mewa Mandai Branch

Peshawar - (Pakistan)

For correspondence, contact the

Centre at the above address.

Vol.2 No.3 August-September 1987 